GLAUCO COSTA LEITE

\title{
A TUTELA JURÍDICA DAS PROPOSIÇÕES ELEITORAIS NO POLO DO PODER EXECUTIVO
}

\author{
Tese de Doutorado \\ Regime de Dupla Titulação \\ Orientadoras: Profa. Dra. MONICA HERMAN SALEM CAGGIANO (USP) \\ Profa. Dra. PILAR JIMÉNEZ TELLO (USAL)
}

Faculdade de Direito da Universidade de São Paulo Facultad de Derecho de la Universidad de Salamanca 



\author{
GLAUCO COSTA LEITE
}

\title{
A TUTELA JURÍDICA DAS PROPOSIÇÕES ELEITORAIS NO POLO DO PODER EXECUTIVO
}

Tese de Doutorado apresentada a Banca Examinadora do Programa de Pós-Graduação em Direito, da Faculdade de Direito da Universidade de São Paulo, em regime de dupla titulação com a Universidade de Salamanca, na área de Concentração Direito de Estado, sob co-orientação da Prof. ${ }^{a}$ Dr. $^{a}$ Monica Herman Salem Caggiano (USP) e Prof. ${ }^{a}$ Dr. ${ }^{a}$ Pílar Jiménez Tello (USAL).

\section{SÃO PAULO}


Catalogaçáo da Publicaçáo

Serviço de Biblioteca e Documentaçăo

Faculdade de Direito da Universidade de Såo Paulo

Costa Leite, Glauco

A TUTELA JURIDICA DAS PROPOSICCOES ELEITORAIS NO

POLO DO PODER EXECUTIVo ; Glauco Costa Leite :

orientadora Monica Herman Salem Caggiano .. Săo

Paulo, 2019.

236

Tese (Doutorado - Programa de Pós-Graduaça em

Direito do Estado) - Faculdade de Direito,

Universidade de Sằ Paulo, 2019.

1. Direito do Estado - 2. Eleiçoes. 3. Democracia.

I. Herman Salem Caggiano, Monica, orient, II. Titulo. 


\author{
GLAUCO COSTA LEITE
}

\title{
A TUTELA JURÍDICA DAS PROPOSIÇÕES ELEITORAIS NO POLO DO PODER EXECUTIVO
}

Tese apresentada ao Programa de PósGraduação em Direito de Estado, como requisito para obtenção do título de Doutor em Direito do Estado.

Orientadoras: Prof. $^{\text {a }}$ Dr. $^{\text {a }}$ Monica Herman Salem Caggiano. 

À minha filha Sofia que me fez descobrir uma porta oculta em meu coração. 



\section{AGRADECIMENTOS}

Em primeiro lugar quero agradecer a Deus por me permitir participar de um programa de doutoramento tão importante e me dar força nos momentos de dificuldade. É motivo de inestimável orgulho fazer parte do corpo dicente de pós-gradução de duas das universidades mais renomadas do mundo: a Universidade de São Paulo (USP) e a Universidade de Salamanca (USAL). Nem em meus maiores sonhos pude imaginar chegar até aqui. Os três anos percorridos no programa somente se mostraram possíveis graças à contribuição de diversas pessoas. Mesmo certo de que não me lembrarei de todos, agradeço em especial:

À minha esposa Cibele, pelo incondicional apoio em todas as horas, e por sempre compreender minhas ausências, estimulando a vida acadêmica.

À minha filha Sofia, responsável pelo maior presente recebido em vida, a paternidade.

Aos meus pais, pelo exemplo de dedicação, amor, perseverança e superação das dificuldades.

Às minhas queridas professoras orientadoras, Professora Monica Herman Salem Caggiano (USP), de quem tenho a honra de ser novamente orientado, e à Professora Pílar Jímenez Tello (USAL). Além das valorosas orientações, ambas se tornaram grande amigas. A vida acadêmica trilhada por ambas reflete a forma como incansavelmente lutam pela defesa do direito, do ensino e de seus alunos.

Ao Professor Doutor Claudio Lembo, que desde o programa de mestrado me levou a conhecer o sábio e culto mestre que era ocultado pelo hábil representante político.

A todos os Professores da Universidade de São Paulo e da Universidade de Salamanca com quem tive a oportunidade de conviver durante todo o período de pesquisa, especialmente: Manoel Gonçalves Ferreira Filho (USP), José Maurício Conti (USP), Rodrigo Pagani de Souza (USP), Marcos Augusto Perez (USP), Fernanda Dias Menezes de Almeida (USP) e Ricardo Rivero Ortega (USAL).

Aos Professores Doutores egressos do programa de pós-gradução Bruno César Lorecini e Alesssandro Soares, pelas orientações de pesquisa. 
Aos colegas do programa de pós-graduação Thalita Abdalla Aris, André Xerez, Nicanor Barry Komata, Alessandra Salles, e ao também amigo de infância, Fernando Fabiani Capano.

Aos colegas magistrados do Poder Judiciário do Estado de São Paulo, especialmente àqueles com quem pude refletir sobre o tema objeto desta pesquisa, o Professor Doutor José Wellington Bezerra da Costa Neto, minha referência como pesquisador, magistrado, amigo e irmão e o Dr. Gustavo Sampaio Correa, amigo de todas as horas, irmão e incansável magistrado.

À Natalia Tammone que, mais uma vez, aceita revisar minha pesquisa, além de apresentar verdadeiras lições de História.

Registro também meus agradecimentos a todos os funcionários das bibliotecas da Universidade de São Paulo e da Universidade de Salamanca, bem como de outras pessoas que, de uma forma ou de outra, me auxiliaram com a presente pesquisa: Camila Tammone, Ana Cristina Vieira Garcia Queiroz, Vagner Bessa, todos os funcionários da $3^{\circ}$ Vara Cível da Comarca de Mauá, minhas estagiárias Beatriz Martins, Brenda Trindade e Bárbara Levorato.

Por fim, a todas as crianças e adolescentes abrigados em Mauá, Ribeirão Pires e Rio Grande da Serra, cujos sorrisos e resiliência inspiram a busca de um mundo mais igual, em especial, Marta, Evelyn, Maria Roberta, Letícia, Endrew, Pablo, Guilherme, Laysla, Veronica, Ericka e Hemilly. 
"La libertad Sancho es uno de los mas preciosos dones que a los hombres dieron los cielos, con ella no pueden igualarse los tesoros que encierra la tierra ni el mar encumbre".

Don Quijote de la Mancha 



\section{RESUMO}

A pesquisa analisa as propostas eleitorais formuladas durante a campanha e a ausência de instrumentos jurídicos aptos a conferir algum grau de eficácia ao cumprimento das proposições. Trata-se de investigação que parte da verificação da existência de crise democrática e de representação política global que reclamam instrumentos que reaproximem o cidadão da política. Analisam-se os diferentes tipos de propostas eleitorais no Brasil e em sistemas alienígenas. Sugere-se a criação de dois instrumentos de controle das propostas eleitorais como forma de combate à demagogia eleitoral e para promover a valorização das eleições. Em sede administrativa, o controle por meio de órgão criado exclusivamente para tal finalidade, refletindo o dever de tutela do Estado pela veracidade das informações relacionadas à efetividade da administração. Em âmbito judicial, sugerese a contratualização de algumas propostas realizadas pelos candidatos com potencial para, em limitadas hipóteses, permitir a tutela jurisdicional coletiva das propostas eleitorais, autorizando-se o Poder Judiciário a conceder a tutela específica correspondente ao objeto da proposta. Estes instrumentos podem conferir maior transparência e coercibilidade no cotejamento entre as propostas eleitorais formuladas e sua efetiva implementação, bem como inserir maior grau de responsabilidade na escolha cidadã.

Palavras-chave: PROPOSTAS ELEITORAIS; REPRESENTAÇÃO POLÍTICA; EFICÁCIA; CONTROLE ADMINISTRATIVO; TUTELA JUDICIAL COLETIVA 


\begin{abstract}
The research analyzes the electoral proposals formulated during the campaign and the absence of legal instruments capable of conferring any degree of effectiveness to the fulfillment of the propositions. This research is based on the verification of the existence of a democratic crisis and a global political representation crisis that demand instruments that bring citizens closer to politics. The different types of electoral proposals in Brazil and in alien systems are analyzed. It is suggested the creation of two instruments to control electoral proposals as a way to combat electoral demagogy and to promote the valorization of elections. In administrative area, it is suggested the control through an institution created exclusively for such purpose, reflecting the State's duty to protect the truthfulness of information related to the effectiveness of the administration. At the judicial level, it is suggested to contract some proposals made by candidates with the potential to, under limited circumstances, allow collective judicial protection of electoral proposals, authorizing the Judiciary to grant specific protection corresponding to the object of the proposal. These instruments can provide greater transparency and coercibility in the comparison between the formulated electoral proposals and their effective implementation, as well as insert greater degree of responsibility in the citizen choice.
\end{abstract}

Keywords: ELECTION PROPOSALS; POLICY REPRESENTATION; EFFICIENCY; ADMINISTRATIVE CONTROL; COLLECTIVE COURT JUDICIAL 


\section{RESUMEN}

La investigación analiza las propuestas electorales formuladas durante la campaña y la ausencia de instrumentos legales capaces de conferir algún grado de efectividad al cumplimiento de las propuestas. Esta investigación se basa en la verificación de la existencia de una crisis democrática y una crisis de representación política global que exigen instrumentos que acerquen a los ciudadanos a la política. Se analizan los diferentes tipos de propuestas electorales en Brasil y en sistemas extranjeros. Se sugiere la creación de dos instrumentos para controlar las propuestas electorales, como una forma de combatir la demagogia electoral y para promover la valorización de las elecciones. En el área administrativa, se sugiere el control a través de una institución creada exclusivamente para tal fin, reflejando el deber del Estado de proteger la veracidad de la información relacionada con la efectividad de la administración. A nivel judicial, se sugiere contratar algunas propuestas hechas por candidatos con el potencial de, bajo circunstancias limitadas, permitir la protección judicial colectiva de las propuestas electorales, autorizando al Poder Judicial a otorgar la protección específica correspondiente al objeto de la propuesta. Estos instrumentos pueden proporcionar una mayor transparencia y coercibilidad en la comparación entre las propuestas electorales formuladas y su implementación efectiva, así como insertar un mayor grado de responsabilidad en la elección de los ciudadanos.

Palabras clave: PROPUESTAS DE ELECCIÓN; REPRESENTACIÓN DE POLÍTICAS; EFICIENCIA; CONTROL ADMINISTRATIVO; CORTE COLECTIVA JUDICIAL 



\section{SUMÁRIO}

INTRODUÇÃO

PARTE I - FUNDAMENTOS PARA ANÁLISE DA DEMOCRACIA, REPRESENTAÇÃO POLÍTICA E PROPOSTAS ELEITORAIS .................................29

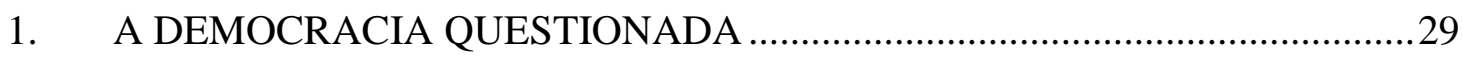

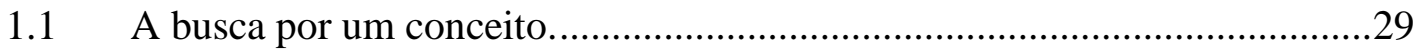

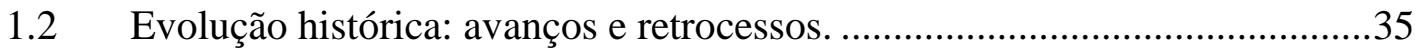

1.3 Características do regime democrático contemporâneo.................................41

1.4 Desigualdade democrática: a democracia aparente. ..................................44

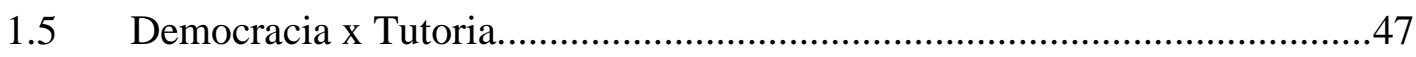

1.6 Avaliação da qualidade democrática........................................................50

1.7 Desafios democráticos na contemporaneidade. .........................................54

2. VINCULO POLÍTICO-ELEITORAL E A INSUFICIÊNCIA DOS

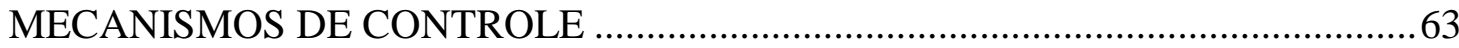

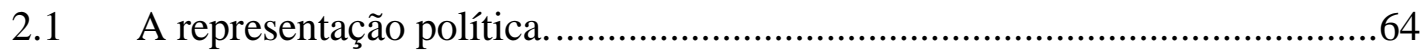

2.2 Natureza jurídica do vínculo político-eleitoral: mandato imperativo $\mathrm{x}$

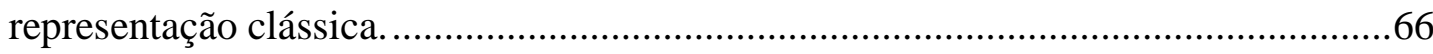

2.3 Tentativas de reaproximação com o mandato imperativo. ...........................72

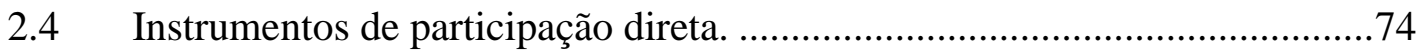

2.5 Confiança política e mecanismos de controle da representação....................80

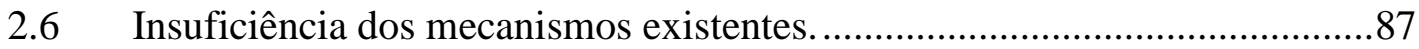

2.7 O Constitucionalismo Aspiracional e a democracia responsiva. ..................88

2.8 O Poder Judiciário e o controle político da representação............................92

3. PROPOSIÇÕES ELEITORAIS E SUA RELEVÂNCIA NAS

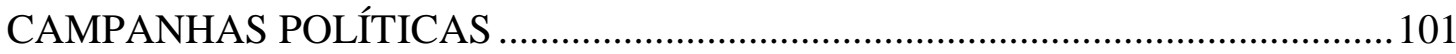

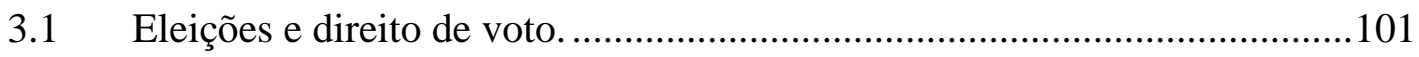

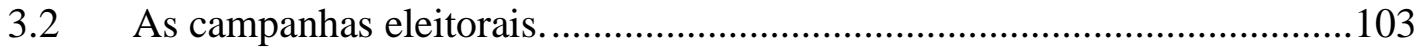

3.3 O processo de escolha de candidatos pelo eleitorado. ................................109

3.4 As proposições eleitorais e a promessa do paraíso. ....................................115

3.5 Natureza jurídica das proposições eleitorais...............................................119 
3.6 As modalidades de proposições eleitorais.

3.7 Da falta de controle jurídico sobre as propostas eleitorais e a busca da eficiência.

3.8 As proposições eleitorais no direito comparado.

3.9 Da necessidade de caráter cogente às propostas.

PARTE II - PROPOSTAS DE CONTROLE ADMINISTRATIVO E JUDICIAL

DAS PROPOSIÇÕES ELEITORAIS

4. CONTROLE ADMINISTRATIVO DAS PROPOSTAS ELEITORAIS

4.1 Eficiência administrativa e avaliação da execução do plano de governo e demais propostas eleitorais.

4.2 O controle das políticas públicas e a parametrização estatística................ 150

4.3 Entidades privadas de controle de políticas públicas................................ 153

4.4 Agências governamentais de análise de estatísticas................................. 155

4.5 O Estado e o dever de tutela da veracidade das informações públicas. ..... 159

4.6 Delineamentos para a criacao de órgão verificador do cumprimento de propostas eleitorais.

4.7 Do processo de análise das propostas e da emissão de parecer acerca do cumprimento.

4.8 Possibilidades de escusa ao cumprimento da proposição.

4.8.1 Cumprimento de proposta que demande aprovação de projeto de lei ou emenda constitucional.

4.8.2 Proposta que depende de recursos financeiros advindos de outra esfera... 177

4.8.3 Cumprimento de proposta obstado por decisão judicial.

4.8.4 Instrumento de democracia direta que altere a conteúdo da proposta........ 178

4.8.5 "Fato do príncipe", teoria da imprevisão e fatos imprevistos. .................... 180

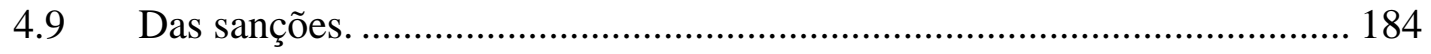

4.10 Da revisão do mérito dos pareceres pelo Poder Judiciário......................... 185

5. SISTEMA DE TUTELAS DAS PROPOSTAS ELEITORAIS GERADORAS DE DIREITO COLETIVO - causas de inelegibilidade, os “contratos políticos" e a cláusula "elegível a direito".

5.1 Causa de inelegibilidade - promessa de cumprimento integral de mandato.

5.2 "Contratos políticos" sob a perspectiva da democracia contratual.

5.3 Da revisão do "contrato político". 
$5.4 \quad$ Tutela jurisdicional coletiva das propostas eleitorais. ..............................200

5.5 Do Procedimento de tutela judicial das propostas eleitorais......................209

5.5.1 Do registro do "contrato político" e da avaliação preliminar. ....................209

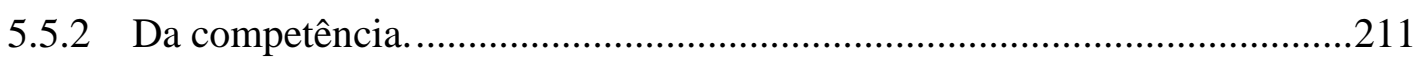

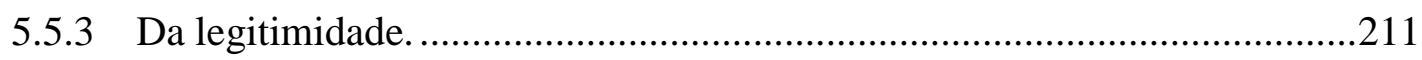

5.5.4 Do processo judicial nos contratos com “cláusulas elegíveis a direito”.....213

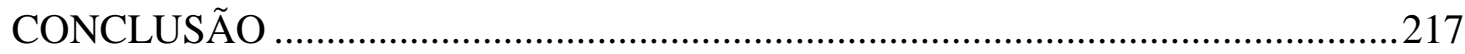

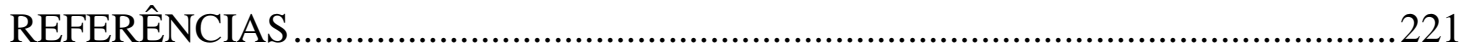

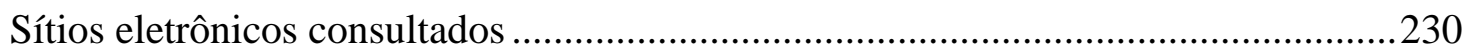

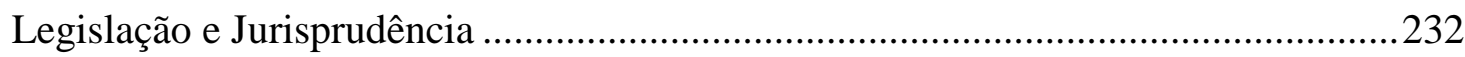

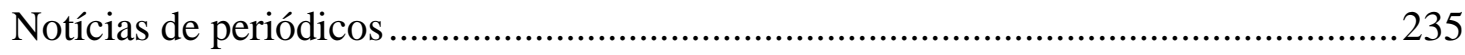





\section{INTRODUÇÃO}

Nos últimos anos a democracia tem sido bastante criticada por não permitir de forma efetiva a participação social, bem como por não ser identificada como instrumento que permite às nações promover transformação social, com redução de desigualdades, distribuição de riquezas, enfim, por não fomentar um aprimoramento social qualitativo. Essa insatisfação, que ocorre não apenas no Brasil, mas em diversos países, tem diminuído o apreço de diversos setores da sociedade pela democracia, levando a questionamentos se a promoção da igualdade social encontra-se ou não dentro dos limites da democracia. Independente da resposta a esta questão o regime democrático comporta aprimoramento, de forma a torná-lo mais racional, efetivo e detentor de maior legitimidade.

Discutir o declínio da aceitação da democracia representa novamente flertar com regimes autoritários. O término da Primeira Guerra pareceu a vitória do princípio democrático, com o fim do Reich alemão. Porém, anos depois, o fascismo na Itália e o nacional-socialismo na Alemanha fortaleceram uma nova forma política, a ditadura. Mesmo com a queda destes regimes após a Segunda Guerra essas filosofias não desapareceram e ainda permanecem latentes, aguardando a possibilidade de ressurgimento a vista de um fraquejar democrático.

Neste cenário, impõe-se uma revisitação à teoria da democracia buscando restaurar sua confiabilidade e uma reaproximação entre o cidadão e a política, por meio de mecanismos jurídicos que possam incrementar o regime democrático. É nesta linha que surgiram os mecanismos de exercício direto da democracia.

A presente pesquisa terá por recorte o momento eleitoral no qual os candidatos apresentam suas propostas aos eleitores visando garantir o voto e, por conseguinte, a legitimidade de representação no pólo do Poder Executivo. É neste momento que o candidato e seu partido, juntamente com as propostas que pretendem implementar, se apresentam ao corpo eleitoral para a disputa em questão. As propostas formuladas em campanha revelarão quais matérias, em tese, nortearão a conduta no gabinete executivo.

Questionamo-nos se esse momento não tem sido negligenciado pela doutrina e pelas instituições jurídico-democráticas. O voto, no sistema representativo, constitui o mais alto momento de participação popular, pois é nele que se estabelece o liame direto que une 
os representantes eleitos para exercício do poder e os representados, o povo. É neste instante, com base nas informações e propostas apresentadas, que o eleitor conferirá legitimidade ao representante eleito para governar e legislar.

O próprio descrédito pelo qual passa a democracia, em muito decorrente da falta de confiabilidade dos representados de que seus interesses são tutelados pelos representantes, impõe que se busque uma alternativa que garanta maior efetividade à representação política. Há uma supervalorização do procedimento eleitoral e das pessoas escolhidas para governar e certo descaso e desregulamentação com a escolha das políticas públicas e ideias defendidas. As mazelas e dificuldades enfrentadas pelo regime democrático importam em analisar se o regime comporta aperfeiçoamentos, pois como teria certa vez asseverado Winston Churchill, a democracia é a pior forma de governo, com exceção de todos os demais regimes.

Por isso, causa certa estranheza a inexistência de qualquer vinculação jurídica efetiva entre o que o representante promete em campanha eleitoral e sua real conduta enquanto administrador, já desde os primeiros dias de governo. Tal situação autoriza um verdadeiro estelionato eleitoral, no qual o representante se vale de propostas populistas, adrede ciente de sua impossibilidade de implementação, apenas com o objetivo de obter os votos necessários a sua eleição, e ciente que não incorrerá em qualquer responsabilização jurídica. Em síntese, as propostas eleitorais passam a ser um verdadeiro jogo de cena, uma absoluta nulidade do ponto de vista jurídico e pura demagogia pelo espectro político.

Buscar uma solução para a falta de confiabilidade nas propostas eleitorais, que até hoje são tratadas como uma vicissitude da própria democracia e da política, não é tarefa simples. Muitos sustentarão que a essência democrática consiste exatamente neste embate de ideias, e que um povo, insatisfeito com um determinado político, negar-lhe-á o sufrágio na eleição seguinte, de tal sorte que a resposta para a questão por nós colocada deveria ser mantida na esfera política, sem repercussão na esfera jurídica.

Todavia, a velocidade com que as mudanças acontecem nos dias atuais não admite que se aguarde todo um mandato para a resposta popular nas urnas. Atualmente, os sistemas democráticos oferecem algumas soluções para a abreviação do mandato de parlamentares e governantes, como o impeachment, o voto de desconfiança nos regimes parlamentaristas, o afastamento judicial das funções, em caráter preliminar ou final, em decorrência da prática de crime ou ato de improbidade e, por fim, o recall, que consiste em o próprio povo retornar às urnas em que elegeu o governante para confirmar a revogação 
de seu mandato por escrutínio, como penalidade pelo descumprimento das promessas eleitorais ou, ao menos, grande ineficiência na tarefa de cumpri-las.

A democracia tem como natureza a soberania popular enquanto uma das razões do constitucionalismo é a limitação ao exercício do poder. Assim, é indispensável que o povo, titular do poder soberano, possa exercer alguma forma de controle em face dos representantes.

O voto manifestado na eleição representa o exato momento em que o povo, titular do poder nos regimes democráticos, transfere parcela desta competência ao representante, que em caráter legítimo, passa a exercer o poder político. No período pré-eleitoral, excetuada, é claro, a possibilidade de reeleição, o ainda candidato não detinha poder político representativo algum, e apenas com o resultado da eleição é que se lhe transmite o múnus público da representação. A imagem que parece representar bem esse procedimento é a de uma corrida de revezamento. É como se o povo, no processo eleitoral, corresse em direção dos representantes que desejam escolher, portando um bastão que contém as razões pelas quais o escolheu. E no exato instante em que o povo transmite o bastão ao representante, observadas as regras da corrida, é que o representante, investido do poder, dá sequência à corrida, não podendo invadir a raia alheia ou deixar cair o bastão, sob pena de desclassificação. Interferir fora dos limites legais em outros poderes corresponderia a invadir a raia alheia e deixar cair o bastão refletiria o não cumprimento com o que se espera do representante, tanto nos aspectos morais, que o tornariam indigno ao cargo, ou naquilo que se afaste da vontade dos eleitores, seja em relação às propostas formuladas em campanha ou na continuidade do diálogo durante a execução do mandato visando uma representação efetivamente responsiva.

É justo que a população que ontem elegeu um candidato com determinada plataforma política hoje veja exatamente o inverso daquilo que foi prometido e tenha que aguardar o término do embuste por quatro anos, sobretudo nos regimes que não possuem o instituto do recall? A retirada de um governante do poder, seja por meio do impeachment ou do recall, representa um processo muitas vezes lento e bastante prejudicial ao desenvolvimento de um país, com repercussões em todas às esferas do governo, especialmente a econômica, diante das incertezas que se abatem, consistindo em um verdadeiro solavanco na democracia e na governabilidade.

Por isso, mesmo nos sistemas que adotam o recall esta tese também nos parece falhar por ser uma espécie de tudo ou nada, não havendo um caminho intermediário, ou seja, só existem duas alternativas: o governante é apeado do poder antes do término do 
mandato ou cumpre todo o mandato, e dele não se pode exigir a observância de quaisquer das promessas neste período ou tampouco promover a quantificação do cumprimento das propostas.

Não seria interessante que houvesse um caminho intermediário?

Este trabalho buscará responder a essa questão, identificando se é possível buscar um ordenamento jurídico legal responsivo (responsiveness), que privilegie a transparência das propostas eleitorais, bem como a aferição quanto a seu cumprimento por meio de um órgão independente e a exequibilidade de algumas propostas de forma cogente.

Em síntese, a premissa da pesquisa consiste em analiar se existe uma crise democrática mundial em curso, algumas de suas causas e como poderiam ser aprimorados os mecanismos democráticos. O problema central da pesquisa, portanto, refere-se à ausência de instrumentos jurídicos aptos a conferir transparência e coercibilidade ao cumprimento das propostas eleitorais aos governantes eleitos.

A tutela do constitucional direito ao voto livre e igualitário implica em diversos fatores. Na seara passiva reflete o direito de lançar candidatura e de realizar campanha eleitoral, enquanto no aspecto ativo a liberdade de escolha dos candidatos e propostas, indene de influências indevidas externas como ameaça e coação. Nota-se que a liberdade na conduta de arregimentar eleitores não é ilimitada, e como tal, a tutela jurídica das propostas poderia trazer maior seriedade e responsabilidade aos proponentes, seja medidante instrumentos de controle administrativo, seja por meio de comando judicial.

Muitas são as razões pelas quais um eleitor escolhe um candidato. Pode ele se afeiçoar à agremiação do candidato, a suas propostas, sua experiência pessoal, sua origem, etnia ou até mesmo o simples fato de não ter seu nome envolvido com escândalos de corrupção. Qual critério tem maior ou menor influência na escolha do eleitor não será objeto de nossa análise no presente estudo, mas apenas a premissa de que as propostas eleitorais representam um liame que o candidato estabelece com o eleitor e que deve ultrapassar juridicamente a data da eleição, de forma que a conduta política do governante seja orientada em confluência com as propostas formuladas.

A hipótese consiste em identificar se é possível discriminar e tutelar a existência de direitos decorrente das proposições eleitorais realizadas, sem que evidentemente se engesse de forma indevida as esferas política e administrativa. Para tanto será necessário identificar o que pode ser exigível, como, quando e por quem. Em seguida, investigaremos potenciais escusas que podem ser apresentadas pelos governantes para o descumprimento das propostas. 
O desafio que propomos no presente trabalho é exatamente esse.

Seria viável que o próprio Poder Público, de forma isenta, ou seja, como atividade de Estado e não de governo, pudesse aferir o cumprimento das propostas para orientar a cidadania nos próximos pleitos, inclusive com a imposição de sanções legais em caso de descumprimento?

Além disso, analisaremos se o descumprimento de propostas eleitorais poderia ter consequências jurídicas previstas na lei, ou mesmo pelo próprio candidato que formulasse as propostas. Seria possível, então, estabelecer "contratos políticos", em que o candidato se comprometesse com determinadas propostas de tal sorte que do descumprimento adviessem consequências jurídicas com a imposição de penalidades ou a concessão de benefícios?

Por fim, nossa pesquisa conduzirá ao questionamento no sentido de identificar se seria possível que o Poder Judiciário, em relação a determinadas promessas e mediante prévia anuência do próprio candidato, não apenas constatasse a omissão da autoridade executiva, mas, substituindo-se ao governante, implementasse diretamente a medida. Nesta hipótese, o próprio candidato apontaria algumas de suas propostas de campanha como "elegíveis a direito", submetendo, por sua própria vontade, eventual descumprimento à tutela judicial direta.

Do ponto de vista metodológico, temos como pressuposto uma reflexão sobre a democracia, cruzando conceitos de ciência política e direito constitucional para avaliar o atual estado da representação democrática. O método dedutivo será utilizado para a pesquisa. Após analisar as bases teóricas para o tema, apresentamos o problema descumprimento doloso das promessas de campanha -, seguido da hipótese, de que o descumprimento é um fator de enfraquecimento democrático e que decorre da falta de mecanismos jurídicos de coercibilidade. Por fim, analisaremos a criação de instrumentos de accountability e coercibilidade como mecanismos de aprimorariamento da eficácia democrática.

Inicialmente, trataremos de situar o espaço epistemológico de nossa pesquisa, demarcando algumas balizas acerca da democracia, do Estado e da responsabilidade política. Contudo, tais abordagens não visam conferir algum caráter taxativo aos conceitos, mas apenas auxiliar na justificação dos alicerces que colocamos para o desenvolvimento da tese.

Um ponto bastante relevante consistirá em distinguir as situações que, embora, em tese, a proposta seja exequível e dentro da esfera de competência do candidato promitente, 
situações externas que poderiam tornar a proposta inexequível. Neste quadrante também se colocam as questões que não dependem exclusivamente do candidato promitente, como também do concurso de outros poderes ou órgãos. E, por fim, identificados os compromissos exequíveis, apontar o procedimento para a efetivação de tais políticas e direitos e a legitimidade daqueles que poderiam pleiteá-las. Tais instrumentos poderiam, talvez, se não restaurar a crença na democracia por parte do demos, ao menos reduzir o distanciamento entre o governantes e governados.

Não será objeto de nosso estudo a influência da mídia nos resultados eleitorais e tampouco o processo psicológico que conduz o eleitor a fazer suas escolhas. Nossa análise estará centrada em avaliar se é possível criar um reforço democrático, conferindo a determinadas propostas eleitorais e mediantes algumas condições, a existência de direito coletivo ao cumprimento da proposta ou ao menos a tomada de medidas na direção do cumprimento.

É inegável que existe certo grau de subjetivismo na escolha das premissas, o que não impede que se busque, ao máximo, a adoção do necessário rigor científico para o desenvolvimento do trabalho.

O trabalho está dividido da seguinte forma:

A primeira parte trata dos fundamentos teóricos para análise dos regimes democráticos, da representação política e das propostas eleitorais de campanha.

No primeiro capítulo tratamos do regime democrático, apresentando conceituação, um excerto histórico do regime, suas características, pressupostos, problemas e desafios. O objetivo é sedimentar na esfera política e constitucional as bases do regime no qual o elemento eleitoral, que mais diz respeito à pesquisa, se insere.

O segundo capítulo pretende discutir o vínculo político-eleitoral que se estabelece entre representantes e representados, assim como a maior aproximação do exercício do mandato com a vontade popular. Neste capítulo serão analisados também os mecanismos atualmente existentes de controle das propostas eleitorais no âmbito político e jurídico, especialmente se são eles suficientes ou comportam ampliação, tendo por fundamento inclusive o processo de juridificação do poder político e de uma democracia responsiva.

No terceiro capítulo, passamos a analisar especificamente as propostas eleitorais. Serão contemplados diferentes aspectos relacionados às campanhas eleitorais e propostas eleitorais, iniciando-se por uma classificação tipológica das propostas. Realizaremos um breve estudo comparado com o sistema de proposições eleitorais de outros países. Por fim, 
será avaliada a necessidade de sancionamento para os casos de descumprimento, chegando até as proposições que poderiam ser objeto de exigibilidade de prestação jurisdicional.

A Parte II do trabalho tratará das propostas de controle administrativo e judicial das proposições eleitorais.

O Capítulo 4 trata do controle administrativo das propostas, tendo por pressuposto o princípio da eficiência e a possibilidade de controle das políticas públicas. Serão analisadas algumas entidades de controle de propostas e políticas públicas, o dever do Estado de tutelar a veracidade das informações públicas, bem como delineamentos para a criação de um órgão de natureza pública responsável pela avaliação do cumprimento das propostas, que denominamos Agência de Verificação de Propostas Eleitorais. Ao final, esboçaremos um pequeno procedimento para análise das propostas, da apreciação de escusas pelo descumprimento por parte dos governantes e da imposição de sanções.

O Capítulo 5 principia tratando da promessa de cumprimento integral do mandato. Em seguida, passa-se a identificar os chamados "contratos políticos", concebidos pelo Prof. Hans Gersbach, em que o candidato se submete a consequências jurídicas, por ele próprio indicadas, pelo cumprimento ou não das propostas eleitorais. Por fim, ingressa-se na área mais sensível do trabalho, ao mesmo tempo mais inovadora e também igualmente mais sujeita a críticas. Trata-se da possibilidade de, na linha dos "contratos políticos", estabelecer cláusulas em que o próprio candidato submetesse o descumprimento, não apenas a consequências jurídicas a ele impostas, mas à abertura da via de tutela judicial coletiva que implicasse na substituição da figura do governante pelo Poder Judiciário para que a medida fosse implementada diretamente.

Ao buscar exemplos dos institutos e da problemática que envolve a presente tese, sem prejuízo de outros países, buscamos privilegiar Brasil e Espanha, porquanto se tratar de tese para a candidatura do doutoramento em regime de dupla titulação junto à Universidade de São Paulo (USP) e a Universidade de Salamanca (USAL). Especialmente pela atualidade do tema, por vezes menções são feitas a notícias colhidas da imprensa escrita e digital, com o escopo de dar suporte às propostas realizadas.

Como menção derradeira, vale consignar que o objetivo maior será o de lançar luzes para o momento eleitoral da apresentação das propostas de campanha, visando o aprimoramento do processo eleitoral e por consequência, do combalido regime democrático. Certamente, há um longo caminho a ser percorrido nesta linha, de tal sorte que a presente tese talvez represente apenas uma nova porta a ser aberta para a discussão do tema. 


\section{PARTE I - FUNDAMENTOS PARA ANÁLISE DA DEMOCRACIA, REPRESENTAÇÃO POLÍTICA E PROPOSTAS ELEITORAIS}

\section{A DEMOCRACIA QUESTIONADA}

Tratar do tema da democracia, ao dar início a esta pesquisa, nos parece particularmente importante por algumas razões. Em primeiro lugar, porque a compreensão sobre o que é democracia, suas implicações e pressupostos constituirão elementos indispensáveis para a crítica realizada em relação às propostas eleitorais. Além disso, nos parece igualmente relevante tratar dos diferentes graus de qualidade democrática, sobretudo porque a discussão relacionada a sanções por descumprimento das proposições eleitorais passa a ter maior relevância nos países com qualidade democrática inferior, em comparação com países em que o nível democrático e de valor dos compromissos públicos atinge níveis mais elevados ${ }^{1}$. Ainda, o questionamento acerca do quanto o sistema de representação democrática tem dado origem à insatisfação popular acende um sinal de alerta para a proliferação de regimes com tendências autoritárias. Esse é um dos principais pressupostos de nossa pesquisa, em que buscaremos empregar um mecanismo de incremento do sistema democrático como forma, inclusive, de autoproteção.

Em síntese, ainda que o objeto deste trabalho trate das propostas eleitorais, nos parece que a pesquisa poderia perder grande parte de seus pressupostos, fundamentos e justificativas, caso não realizássemos um estudo prévio pormenorizado do instituto democracia, especialmente no estágio contemporâneo, para então aprofundarmos questões mais próximas às proposições eleitorais.

\subsection{A busca por um conceito.}

${ }^{1}$ Trataremos dos níveis de qualidade democrática no curso deste capítulo. Por ora, basta ter presente que quanto maior for a identidade entre os requisitos democráticos e a real prática política, maior será o nível democrático. Ao revés, uma identidade deficitária em relação aos requisitos não necessariamente permitirá que se negue a existência de democracia em um determinado agrupamento, mas poderá permitir que se aponte estar diante de uma democracia de qualidade inferior. 
Não é nenhum pouco simples a tarefa de conceituar o que vem a ser democracia. Em primeiro lugar porque se trata de tema que interessa a diversos ramos do conhecimento científico e não apenas ao Direito. A democracia é objeto de estudo da Ciência Política, da Filosofia, da Economia, da Antropologia, da Sociologia, dentre outras.

A Filosofia se interessa pela democracia e terá por objeto seus valores morais, a virtude. A Ciência Política também trata da democracia no que tange aos sistemas políticos e ao comportamento político. O desenho democrático importa para a Economia que pode traçar cenários futuros a vista de determinadas tendências eleitorais ou sistemas políticos. A Sociologia tem interesse no papel do eleitor/cidadão em face do poder político.

Os estudos em ciência política apresentam certas dificuldades na medida em que seus resultados tendem a sempre ter um elemento de apreciação subjetiva, ainda que diante da análise de dados objetivos ${ }^{2}$. Por isso Duverger dizia que na teoria política o desconhecido, "terrae incognitae", é sempre maior que o conhecido, "terrae cognitae"3. Entretanto, tais dificuldades não podem sugerir o abandono ou desvalorização dos métodos existentes, sob pena de se desamparar a ciência à sorte de crenças políticas primitivas e à falta de crítica ${ }^{4}$.

O cientista jurídico, de seu turno, procurará amalgamar os elementos da virtude e os pressupostos democráticos da ciência política transformando-os em objeto do Direito, como instituições, normas e decisões. Mesmo em relação à Ciência do Direito, a democracia se relaciona tanto com o Direito Constitucional e Administrativo, como com o Direito Civil, Processual Civil e Direito Internacional.

Não bastasse isso, a própria palavra democracia é polissêmica, e pode ser tomada em diferentes significados e abrangências, a depender inclusive do período histórico e da sociedade em que analisada.

Buscar uma definição implica em compreender o significado e o alcance de um determinado objeto. Antes de adentrar ao conceito de democracia, impõe-se estabelecer

2 “(...) Tous les phènomènes sociaux présentent des caratères qui les rendent plus difficile à étudier que les phénoménes physico-chimiques. Une grande partie de leurs éléments ne sont pás mesurables: leur description comporte um élément d'appréciation personnelle plus ou moins grand, qui rend plus difficiles les comparaisons objectives. Les réactions personnelles de l'observateur et de l'observé entraînent des déformations dans toute observation: on ne peut éliminer que partiellement les déviations qui em résultent. Beaucoup de phénoménes échappent à toute observation, soit parce qu'on les dissimule aux observateurs possibles, soit parce qu'il n'y a pas de techniques d'observation adéquates, etc". DUVERGER, Maurice. Institutions Politiques et Droit Constitutionnel - Les grands système politiques. Paris: Presses Universitaires de France, $12^{\circ}$ Ed, 1971, t. 1, pp. 45-46.

${ }^{3}$ Idem, Ibidem, pp. 45-46.

${ }^{4}$ BERLIN, Isaiah. Dos Conceptos de Libertad. El fin justifica los medios. Mi trayectoria intelectual. (Traducción de Ángel Rivero). Madrid: Alianza Editorial, 2 ed., 2014, p. 58. 
qual será a abrangência de poder político analisada. O poder político pode ser classificado de forma ampla, abarcando todo e qualquer exercício de poder, em qualquer agrupamento humano, como o poder econômico, eclesial ou de organizações profissionais, ou limitar-se ao poder dos governantes e dos parlamentares no exercício da atividade estatal. Este último significado é o que adotamos para o presente estudo.

O primeiro recorte epistemológico que se faz necessário consiste em indicar que a democracia, enquanto objeto de estudo da ciência do direito, não pode se bastar em discussões filosóficas, ideológicas ou relacionadas apenas a um sistema ideal, sendo imperioso que o jurista, valendo-se dos valores democráticos, compreenda a democracia dentro de um sistema de normas, que visem exatamente à concretude de tais valores. $\mathrm{O}$ conceito de democracia tem também raízes de derivações históricas de modo que, o teste das ideias, e por consequência dos conceitos, ocorre no próprio campo histórico, no destino das sociedades e das instituições políticas ${ }^{5}$.

Fixadas as premissas relativas ao poder político estatal e à democracia como sistema de normas, passamos a analisar os diversos conceitos de democracia.

Em 1863 Abraham Lincoln formulou o que talvez seja o conceito mais simples e objetivo de democracia, como o governo do povo, pelo povo e para o povo ${ }^{6}$. A despeito da sonoridade e do elevado conteúdo moral, enfatizando o renascimento da liberdade, o conceito carece de parâmetros mínimos que possam indicar quem é o povo, como ele governa e como se identificam seus interesses comuns. Caggiano, ao analisar tal assertiva, aponta que se trata, na verdade, de uma receita política que impõe a indisponibilidade do pluralismo político e a livre manifestação das opções políticas, de tal sorte que as preferencias da comunidade sejam espalhadas pelo polo governante ${ }^{7}$.

A palavra democracia teve origem no grego $($ demos $=$ povo, kratein $=$ governo $) . \mathrm{O}$ filósofo Aristóteles apontava o homem como um animal político, detentor de um zoon

${ }^{5}$ SARTORI, Giovanni. A Teoria da Democracia Revisitada. São Paulo: Ática, 1994,v.2, pp. 18-19 e 29.

6 " (...) shall have a new birth of freedom; and that government of the people, by the people, and for the people (...)" Lincoln's Gettysburg address at the National Cemetery at Gettysburg, Pennsylvania. Disponível em Library of Congress: <https://cdn.loc.gov/service/rbc/lprbscsm/scsm0365/scsm0365.pdf. Acesso em 06/09/2017>.

7 CAGGIANO, Monica Herman S. "Democracia x constitucionalismo: um navio à deriva?" In: Cadernos de Pós-Graduação em Direito: estudos e documentos de trabalho / Comissão de Pós-Graduação da Faculdade de Direito da USP, São Paulo, n. 1, 2011, p. 8. 
politikon $^{8}$, alguém que intrinsecamente volta-se para à vida em sociedade e não apenas para sua vida privada.

O que se define contemporaneamente como a democracia representa um instituto bastante distinto daquele identificado na Grécia antiga. Por isso seu conceito é bastante impreciso e até certo ponto subjetivo, instável, moldável de acordo com os valores reinantes, e insuscetível de rígidos controles de análises, como os realizados em pesquisas nas áreas de ciências exatas.

Em uma abordagem dicotômica diferenciam-se apenas os regimes democráticos das não-democracias, sem juízo de valor em relação a quanto o regime se volta ao bem comum. Por outro lado, ao se propor uma análise mais ampla e profunda do tema, é necessário utilizar uma escala de graus democráticos. Os sistemas não democráticos podem ser classificados em totalitários e sistemas autoritários tradicionais 9 .

No que tange à natureza jurídica, a democracia pode ser pensada enquanto forma de governo, como fonte de autoridade, como procedimento para a constituição de governo e como propósito de governo.

Segundo Kelsen, a democracia é uma forma de governo, um meio de criação da ordem social $^{10}$. Essa forma de governo se opõe aos governos autoritários, totalitários e epistocráticos, tendo como elemento fundante a liberdade. Ao tratar da liberdade, mais uma vez, estamos diante de palavra polissêmica, de alto valor moral, e que exige que o filósofo e o jurista a interpretem para limitar seu significado e amplitude. Qual seria, então, essa liberdade que fundamenta a democracia?

8 “É, portanto, evidente que toda Cidade está na natureza e que o homem é naturalmente feito para a sociedade política. Aquele que, por sua natureza e não por obra do acaso, existisse sem nenhuma pátria seria um indivíduo detestável, muito acima ou muito abaixo do homem, segundo Homero: Um ser sem lar, sem família e sem leis". ARISTÓTELES. A Política (Trad. Roberto Leal Pereira). São Paulo: Martins Fontes, 2002, p. 4.

9 Sistemas totalitários: partido único, normalmente liderado por uma só pessoa; polícia secreta poderosa; ideologia baseada em uma sociedade em perspectiva a ser atingida; alta penetração governamental; controle das comunicações de massa e de grande parte das organizações sociais e econômicas. Sistemas autoritários tradicionais não-democráticos: liderança exercida por uma única pessoa ou por pequeno grupo; ausência de partidos políticos ou partido sem força política; inexistência de mobilização social; pluralismo político limitado; ausência de tentativas de mudança. HUNTINGTON, Samuel. P. A Terceira Onda. São Paulo: Editora Ática, 1994, p. 22. Manuel Gonçalves Ferreira Filho esclarece que no regime totalitário existe uma ideologia oficial, partido político único, de massa, que tem o controle da mobilização social, ficando o governo circunscrito a um pequeno grupo de pessoas que não pode ser removida do poder por meios ordinários e institucionais. Sobre o regime autocrático aponta que implica em um limitado pluralismo político, sem uma ideologia elaborada, com baixa mobilização política, e com um grupo que governa dentro de limites mal definidos. FERREIRA FILHO, Manuel Gonçalves. Curso de direito constitucional. $35^{\circ}$ ed., São Paulo: Saraiva, 2009, p. 79.

${ }^{10}$ KELSEN, Hans. A Democracia.. São Paulo: Martins Fontes, 1993, p. 103. 
Isaiah Berlin apresenta dois critérios para identificação da liberdade, um negativo, que implica na esfera privada do indivíduo a qual não pode haver interferência de outras pessoas ou do governo, e um positivo, que implica em quem ou o quê pode determinar que alguém seja obrigado a fazer uma coisa ou outra. Estes critérios podem ser identificados na resposta a duas perguntas: quem me governa? (liberdade positiva) e até que ponto eu sofro a interferência do governo? (liberdade negativa) ${ }^{11}$.

Sobre um viés ideológico, lembra Kelsen, a democracia assenta-se em dois pilares: a liberdade e a igualdade formal. Porém, é a liberdade que determina a democracia em primeiro lugar. A democracia é uma luta histórica pela liberdade política ${ }^{12}$. Igualdade, neste caso, difere de igualdade política. Kelsen aponta que aparentemente o fato de que os seres humanos são todos iguais poderia induzir à conclusão de que ninguém deve mandar em ninguém. Há, portanto, uma ideia de oposição entre a liberdade individual e a de ordem social. Porém, a experiência e, acrescentamos, a razão, ensinam que "se quisermos ser realmente todos iguais, deveremos deixar-nos comandar"13.

Os conceitos que estabelecem distinções meramente idealistas de democracia são incompletos e suscitam divergências inclusive de conteúdo moral, enquanto os aspectos institucionais e empíricos permitem maior precisão analítica. Por isso, a democracia reside em terreno mais pacífico e consensual quando conceituada como procedimento de escolha de líderes, por meio de eleições competitivas pelo povo ${ }^{14}$.

Para Norberto Bobbio, a democracia representa um conjunto de regras (primárias ou fundamentais) que estabelecem quem pode tomar as decisões coletivas e mediante quais procedimentos $^{15}$. É certo, porém, que se trata de um elemento mínimo, que não garante que governos regularmente eleitos em regimes democráticos tenham condutas que se voltem ao atingimento do bem comum. Por tal razão, passou-se a discutir se deve existir efetivo controle sobre a política, para que os governos sejam responsáveis, probos, promovam deliberação racional e bem informada, bem como autorizem participação igualitária. Esta

${ }^{11}$ BERLIN, Isaiah. Dos Conceptos de Libertad. El fin justifica los medios. Op. cit., p. 74.

${ }^{12}$ KELSEN, Hans. A Democracia. Op. Cit., p. 99.

13 "Se deve haver sociedade, e mais ainda, Estado, deve haver um regulamento obrigatório das relações dos homens entre si, deve haver um poder. Mas, se devemos ser comandados, queremos sê-lo por nós mesmos. A liberdade natural transforma-se em liberdade social ou política. É politicamente livre aquele que está submetido, sim, mas à vontade própria e não alheia. Com isso apresenta-se a antítese de princípio das formas políticas e sociais". KELSEN, Hans. A Democracia. Op. Cit., pp. 27-28.

${ }^{14}$ Opõe-se, portanto, a outros sistemas em que o poder não é atingido pelo sufrágio, mas por meio de violência ou em razão do nascimento, como no caso das monarquias hereditárias.

${ }^{15}$ BOBBIO, Norberto. O Futuro da Democracia (Trad. Marco Aurélio Nogueira). São Paulo: Paz e Terra, 2000, p. 33. 
linha, contudo, prestigia a dificuldade de análise e comparação, razão pela qual alguns autores, como Bobbio, preferem o conceito limitado ao aspecto procedimental de escolha de líderes ${ }^{16}$.

Giovanni Sartori não se estusiasma em conceituar a democracia. Prefere realizar uma análise comparativa para dizer que, mais relevante do que saber o que é a democracia, é identificar por que ela é mais desejável do que outros regimes. E assim, uma possível resposta seria que a democracia é preferível, pois a liberdade é prevalente nos regimes democráticos, sendo a liberdade melhor e mais desejável do que a falta de liberdade dos regimes autocráticos. Conclui afirmando que os sistemas políticos acabam por enfrentar um problema de escolha entre melhor e pior, e não entre bom e mau em sentido absoluto e, portanto, não poderia "provar a democracia", mas argumentar no sentido de que ela é preferível a outros sistemas ${ }^{17}$.

Robert Dahl, ciente da miríade de utilizações que a palavra democracia recebe, prefere falar em um conjunto de regras e princípios que especifique como são tomadas as decisões, o que será analisado com maior profundidade à frente ${ }^{18} . \mathrm{O}$ aspecto procedimental da democracia é indissociável do direito, que corresponde ao principal instrumento de exercício do poder nas sociedades contemporâneas democráticas, embora não seja o único meio de exercício do poder, como aponta em lição clássica Maurice Duverger ${ }^{19}$.

Analisando a natureza da democracia e do aumento de participação política, sob um aspecto epistemológico e instrumental, a democracia é considerada boa porque nos conduz a resultados justos, eficientes e estáveis. Já sob uma lente aretológica, tendo por premissa a virtude, a democracia tende a educar, iluminar e enobrecer os cidadãos. Por fim, se verificada de forma intrínseca, a democracia e a participação política seriam um bem em si mesmo ${ }^{20}$.

16 “Governos eleitos podem ser ineficientes, corruptos, de visão estreita, irresponsáveis, dominados por interesses específicos e incapazes de adotar as políticas exigidas pelo bem público. Tais características podem tornar tais governos indesejáveis, mas não os tornam não-democráticos. A democracia é uma virtude pública, mas não a única, e a relação entre a democracia e as outras virtudes e vícios públicos só pode ser entendida se a democracia for claramente diferenciada de outras características dos sistemas políticos" HUNTINGTON, Samuel. P. A Terceira Onda. Op. Cit., p. 19.

${ }^{17}$ SARTORI, Giovanni. A Teoria da Democracia Revisitada. São Paulo: Ática, 1994, v. 2, pp. 18 19.

${ }^{18}$ DAHL, Robert. Sobre a democracia (Tradução Beatriz Sidou). Brasília: Editora Universidade de Brasília, 2001, pp. 48-49.

19 "Dans les sociétés modernes, le droit est l'un des instruments essentiels du pouvoir. (...) Les Constituitions, les codes, les lois, les règlements, les décisions administratives, les jugements des tribunaux sont des moyenes d'actions fontamentaux du pouvoir". DUVERGER, Maurice. Institutions Politiques et Droit Constitutionnel - Les grands système politiques. Op. Cit., p. 13.

${ }^{20}$ BRENNAN, Jason. Against Democracy. Princeton: Princeton University Press, 2016, p. 7. 
Nota-se que já parece não mais satisfazer ao conceito democrático o mero aspecto procedimental, mas sim uma real preocupação com a o interesse do demos, o povo. É importante alertar, porém, para o fato de que a democracia não representa uma panaceia para a solução de todos os problemas sociais de um determinado agrupamento social. Talvez seja exatamente a crença de que a democracia deva conduzir inexoravelmente à evolução sócio-economica a representação de sua maior vulnerabilidade na sociedade contemporânea.

Nesta linha de ideias, a busca por um conceito, malgrado relevante, não é indispensável, para o estudo do tema. Mais relevante nos parece observar quais são seus elementos mínimos e enfatizar que qualquer análise deve ser realizada com apreciação histórica, sob pena de anacronismos, como pretender negar a existência da democracia ateniense antiga, sob o argumento de que escravos e mulheres não votavam.

Portanto, resta até aqui apenas sublinhar que a democracia corresponde à forma de governo na qual o povo, livremente, sob aspecto formal, e valendo-se das normas vigentes e preestabelecidas, escolhe quem os governa. O quanto o governo eleito vai se aproximar da vontade do povo caracterizará elemento de qualidade da democracia, mas não de sua exclusão.

Passemos, então, a um breve escorço histórico da democracia.

\subsection{Evolução histórica: avanços e retrocessos.}

Em linhas bastante gerais, a evolução histórica da democracia pode ser observada na Antiguidade, com o distintivo do caráter direto do exercício democrático, na Idade Moderna, com a representação política fruto das teorias contratualistas, e na Idade Contemporânea, com a manutenção da representação política, com foco em instrumentos de aperfeiçoamento, como ferramentas de democracia direta, transparência, eficácia e maior responsabilização dos governantes.

A origem da democracia remonta à Grécia Antiga, especificamente na cidadeestado de Atenas ${ }^{21}$. O conceito ateniense de cidadania implicava na participação direta no cidadão nos negócios de estado. A virtude cívica consistia subordinar a vida privada aos problemas públicos e ao bem comum. A democracia ateniense se caracterizava pelo

\footnotetext{
${ }^{21}$ Entre os anos de 509 a.C. (reformas de Clístenes) até 404 a.C. (derrota na guerra do Peloponeso) e, posteriormente, entre 403 a.C. até 322 a.c. FERREIRA FILHO, Manuel Gonçalves. A democracia no Limiar do Século XXI. São Paulo: Saraiva, 2001, pp. 3-4.
} 
autogoverno direto pelo povo, que se reunia na Ágora em assembleia popular (ecclesia), com todos os cidadãos atenienses com direito a manifestações e proposições, sendo as decisões tomadas por maioria de votos. A assembleia tratava das principais questões relacionadas à manutenção da ordem pública, impostos, ostracismo e relações exteriores. Embora sempre se buscasse a unanimidade (homonoia), reconhecia-se a divergência de opiniões e o princípio da maioria por meio do voto era adotado para solucionar as questões $^{22}$.

É indispensável identificar quem tinha o direito de ser considerado cidadão em Atenas, que eram apenas os homens, estando excluídas todas as mulheres, os escravos, os libertos, os estrangeiros, os nascidos em Atenas, mas cujos pais não fossem atenienses. Portanto, em um universo populacional de aproximadamente 300.000 pessoas, apenas $40.000(13 \%)$, eram considerados cidadãos ${ }^{23}$. Por essas razões seria possível inclusive negar a existência de democracia em Atenas. Entretanto, a democracia ateniense deve ser compreendida à luz das circunstâncias e cultura de seu tempo. Deste modo, evidentemente não seria possível denominar de democracia o arranjo político da Grécia Antiga à luz dos pressupostos de liberdade política contemporânea exigida para a qualificação de um regime democrático.

Para Aristóteles a democracia representava uma forma corrompida porque o povo aspira vantagens pessoais próprias, e não o bem comum de toda a sociedade ${ }^{24}$. Por isso, propõe o governo misto, em que a busca da mediania e o controle das paixões ocorreria de forma institucional, em que feixes de poder de um governante fossem refreados pelos demais, promovendo um sistema que se protegeria da corrupção e voltado para a virtude ${ }^{25}$.

${ }^{22}$ Abaixo da assembleia havia o conselho (boulé), formado por quinhentos cidadãos, escolhidos por sorteio, proporcionalmente escolhidos entre as tribos, que só assumiam a função após um exame para verificar se eram dignos do cargo, tanto em sua conduta pública como privada (dokimasia), e exerciam a função por um ano. Era composto por um órgão ainda menor, chamado comitê dos 50, em que os cidadãos serviam por um mês, e cujo presidente só podia exercer o cargo por um único dia. Os magistrados eram responsáveis pelas funções executivas da polis, ou seja, não exerciam funções judiciárias como atualmente possuem. HELD, David. Models of Democracy. $3^{\circ}$ Ed. Cambridge: Polity Press, 2017, pp. 17-19.

6.

${ }^{23}$ FERREIRA FILHO, Manuel Gonçalves. A democracia no Limiar do Século XXI. Op. Cit., pp. 4

24 “Não é sem razão que se censura tal governo e, de preferência, o chamam democracia ao invés de República; pois onde as leis não têm força não pode haver República, já que este regime não é senão uma maneira de ser do Estado em que as leis regulam todas as coisas em geral e os magistrados decidem sobre os casos particulares. Se, no entanto, pretendermos que a democracia seja uma das formas de governo, então não se deverá nem mesmo dar este nome a esse caos em que tudo é governado pelos decretos do dia, não sendo então nem universal nem perpétua nenhuma medida”. ARISTÓTELES. A Política. Op. Cit., p. 111.

${ }^{25}$ A virtude para Aristóteles seria um estado de caráter dos homens em relação às paixões. A política ocorre como ato, enquanto a corrupção corresponde em potência, sendo a virtude o elemento estabilizador do sistema. FILGUEIRAS, Fernando. Corrupção, Democracia e Legitimidade. Belo Horizonte: Editora UFMG, 2008, p. 34. 
O ideal aristotélico prevê a existência de um rei ou chefe do executivo (monarquia), assessorado por uma assembleia de homens destacados, a cargo de quem estaria a elaboração das leis e julgamento dos crimes (aristocracia).

Durante a Idade Média a visão cristã de mundo transformou a racionalidade da ação política em um padrão ideológico. A preocupação entre os cidadãos deixa de ser como eles devem se organizar socialmente, mas sim como eles devem relacionar-se com Deus. De certa forma, o ideal de igualdade política é preservado no Cristianismo, na medida em que todos são considerados iguais perante Deus. Esse espectro ideológico de igualdade serve de base para a justificação de um arranjo institucional que incluía escravidão, servidão e pobreza. Nota-se que são amalgamados elementos contraditórios, pois de um lado, todos são iguais perante Deus, mas de outro, social e politicamente, devem ser admitidas diferentes estamentos na sociedade e na vidade polítca ${ }^{26}$. Havia, portanto, uma divisão clara entre a vida espiritual e a vida secular. São Tomás de Aquino apontava que embora a monarquia para ele fosse a melhor forma de governo, a autoridade do monarca não deveria ser ilimitada. A legitimidade do monarca encontrava limite no direito natural, sendo que violações reiteradas do direito natural justificariam a ideia de rebelião ${ }^{27}$.

A democracia se desenvolve em paralelo com o desenvolvimento do Estado. $\mathrm{Na}$ Idade Moderna, do Século XIV até o final do Século XVIII, a democracia podia ser observada apenas em estados de extensão bastante diminuta e população reduzida, como nos Cantões na Suíça. A impossibilidade de autogoverno direto nos grandes estados não se deve apenas à limitação física de reunião do povo nas assembleias, mas também ao próprio desconhecimento técnico e desinteresse do povo em participar das decisões possíveis, segundo apontava Montesquieu ${ }^{28}$.

As Revoluções Burguesas ocorridas na Inglaterra no Século XVII e na França no Século XVIII visavam limitar o poder da monarquia, estabelecendo uma igualdade formal perante a lei (rule of law). Embora a preocupação aqui não fosse necessariamente com a democracia, mas com a limitação do poder estatual e a pavimentação de bases para o liberalismo, é certo que a instituição do rule of law servirá de suma importância como pressuposto para que o autogoverno democrático possa ser implementado. O Direito

\footnotetext{
${ }^{26}$ HELD, David. Models of Democracy. Op. Cit., pp. 29-31. Expoente deste período é Santo Agostinho que escreve a obra A Cidade de Deus.

${ }^{27}$ AQUINAS, St Thomas. "De regimine principum". In: Aquinas: Selected Political Writings. Ed. A.P. D'Entrèves. Oxford: Backwell, 1948, p. 31.

28 "Mais saura-t-il conduire une affaire, connoître les lieux, les occasions, les moments', en profiter? Non; il ne le saura pas". MONTESQUIEU, Charles-Louis de Secondat. De l'esprit des loi. Paris: Vve Dabo, 1824, Livro II, Cap. 2, pp. 17-18.
} 
Constitucional se desenvolve, então, ao mesmo tempo em que a democracia liberal. A aproximação do desenvolvimento do direito constitucional e das regras jurídicas conferiu grande avanço ao estudo das instituições políticas.

Passa-se a conciliar a democracia com a técnica da representação política, de modo que esta seria indispensável para o pleno exercício daquela. Em 1748 Montesquieu escreve $O$ Espírito das Leis, em que indica que a democracia repousa sobre a virtude, em que o governante deve ser abnegado, sóbrio, e sacrificar-se pela coletividade, de modo que passa a admitir a representação ${ }^{29}$. Ao trazer a ideia de divisão tripartite do poder, pedra de toque do pensamento iluminista, Montesquieu busca um equilíbrio no exercício da força política, com vistas ao combate do arbítrio e de governos de feições autoritárias. Em 1762 Jean Jaques-Rousseau escreve $O$ Contrato Social, criticando a representação política, mostrando-se cético ao funcionamento efetivo de um sistema de representação que efetivamente preservasse o interesse dos representados ${ }^{30}$.

Na Idade Contemporânea, no final do século XIX, sedimenta-se a democracia representativa por meio de partidos políticos ${ }^{31}$. Partido político pode ser conceituado como um agrupamento livre e estável de pessoas que, reunidas em razão de um conjunto de idéias em comum, se dispõe a participar do certame eleitoral com o escopo de conquistar poder político para implementar políticas próprias ${ }^{32}$.

As ondas democráticas representam períodos em que se observa uma maior transição para regimes democráticos enquanto as ondas reversivas fazem referência a períodos históricos em que se observa uma maior e mais concentrada incidência de transições de regimes democráticos para regimes autoritários. Mercê da própria historicidade, podem ser notadas liberalizações mesmo durante processos de reversão,

29 "Lorsque cette vertu cesse, l'ambition entre dans les coeurs qui peuvent la recevoir, et l'avariceentre dans tous. Les désirs changent d'objets; ce qu'on aimoit, on ne l'aime plus; on étoit libre avec les lois, on veut être libre contre elles; chaque citoyen est comme un esclave échappé de la maison de son maître (...)". Idem, Ibidem, pp. 40-41. "Comme la plupart des citoyens, qui ont assez de suffisance pour élire, n'en ont pas assez pour être élus ; de même le peuple, qui a assez de capacité pour se faire rendre compte de la gestion des autres, n'est pas propre à gérer par lui-même”. Idem, Ibidem, p. 18.

${ }^{30}$ ROUSSEAU, Jean-Jacques. Le Contrat Social. $1^{\circ}$ ed. Paris, 1851, Livro I, Cap. VI, p. 3.

${ }^{31}$ Presentes os pressupostos que atualmente são aceitos como indispensáveis para a caracterização de um regime democrático, a Nova Zelândia pode ser tomada como o primeiro país democrático, pois desde 1893 adota o sufrágio universal. LIJPHART, Arend. Patterns of Democracy: government forms and performance in thirty-six countries. New Heaven/London: Yale University Press, 2 ed., 2012, p 45.

${ }^{32} \mathrm{O}$ que diferencia os partidos políticos de outras instituições que, em tese, também persigam os mesmos fins, é a necessidade de poder. DÍAZ, Angel Eduardo Alvarez. "Los contenidos de la propaganda electoral y la protecction de la racionalidad politica del elector". In: MAGALLANES, Manuel Vicente (coord.) Propaganda Política Partidos y Sistema Electoral. Consejo Supremo Electoral, Colección del Cincuentenario 2. Caracas: Miguel Angel García e Hijo, s.r.l.: 1987, p. 75. 
assim como recrudescimento democrático em período correspondente a onda democrática $^{33}$.

A primeira onda de democratização (1826-1926) embora tenha raízes nas revoluções americana e francesa, surgem no Século XIX, com os Estados Unidos (1928), seguidos por Suíça, França, Grã-Bretanha e vários outros países europeus menores. Espanha e Chile tornam-se democráticos no início da década de 1930, quando a primeira onda já havia terminado. A primeira onda reversa (1922-1942) corresponde à introdução de novas formas de totalitarismo que antecederam a Primeira Guerra Mundial ou logo após seu início. Inicia-se em 1922 com o controle de Mussolini na Italia, seguida por Lituania, Estonia, Polonia e Letonia. A chegada de Hitler ao poder em 1933 colocou fim à democracia alemã. Golpes Millitares ocorreram também em Portugal (1926), Brasil (1930), Argentina (1930), Uruguai (1933) e Espanha (1939). Ocorre a ascenção de ideologia fascista comunista e militarista ${ }^{34}$.

A segunda onda de democratização (1943-1962) começou com o fim da Segunda Guerra Mundial. A ocupação de aliados promoveu instituições democráticas na Alemanha Ocidental, Italia, Austria e Coréia. Entre 1940-50, Turquia e Grécia caminhavam para a democracia. Brasil, Uruguai, Argentina, Costa Rica, Peru e Venezuela retornaram a regimes democráticos. A segunda onda de reversão (1958-1975) teve início nos anos 60, sendo observada de forma clara na América Latina, com golpes militares no Brasil e Bolívia (1964), Argentina (1966), Equador (1972), Uruguai e Chile (1973). O mesmo ocorreu na Ásia, notadamente no Paquistão, Turquia, Coréia e Filipinas ${ }^{35}$. Na África alguns países instalaram democracias que perduraram por curtos períodos, como na Nigéria. A onde reversiva fica comprovada quando se nota que em 1962 havia 13 governos no mundo resultado de golpes militares, ao passo que em 1975 correspondiam a $38^{36}$.

No Século XX as democracias foram substituídas por regimes antidemocráticos em aproximadamente 70 ocasiões, quase sempre em democracias mais jovens, com menos de uma geração de idade ${ }^{37}$.

${ }^{33}$ HUNTINGTON, Samuel. P. A Terceira Onda. Op. Cit., p. 23.

${ }^{34}$ Idem, Ibidem, pp. 25-27.

${ }^{35}$ Os militares turcos tomaram o poder em 1960, restituíram a autoridade a um governo eleito em 1961, realizaram uma nova intervenção em 1971, permitindo a volta de um governo eleito em 1973, culminando com uma tomada militar total em 1980.

${ }^{36}$ HUNTINGTON, Samuel. P. A Terceira Onda. Op. Cit., pp. 28-30.

${ }^{37}$ DAHL, Robert A. A Constituição Norte-Americana é Democrática? (Tradução de Vera Ribeiro, revisão técnica de Mario Brockmann Machado). Rio de Janeiro: FGV Editora, 2015, p. 125. 
A terceira onda democrática (a partir de 1974) ocorreu em Portugal, Grécia, Espanha, Equador, Peru, Bolívia, Argentina, Uruguai, Brasil, Guatelama e Índia. Hungria (1988) e Uniao Sociética (1989), Alemanha Oriental, Tchecoslováquia e Romênia (1990). Chile (1988), Panamá e Nicarágua. Em 1974, dos 10 países da Amercia do Sul, 8 tinham regimes não-democráticos, ao passo que em 1990, nove tinham escolhido governantes por meios democráticos ${ }^{38}$.

Os processos de democratização consistem no fortalecimento das instituições, de modo que atores políticos com poder de força aderem a instituições democráticas. Nem sempre tais processos conduzem a uma consolidação democrática, podendo haver retrocessos e até mesmo o retorno a regimes autoritários ${ }^{39}$. A terceira onda democrática fez saltar o número de estados democráticos no mundo de 35 em 1970 para mais de 110 em $2014^{40}$.

Huntington arrola os fatores que contribuíram para a primeira e segunda onda reversa: (1) fraqueza dos valores democráticos; (2) crise ou colapso financeiro que intensificaram os conflitos e acentuaram a popularidade de remédios autoritários; (3) polarizações sociais e políticas; (4) grupos conservadores de classe média e alta que visavam excluir do poder político os movimentos populares e os grupos de classe baixa; (5) falência da lei e da ordem em razão de terrorismo e insurreição; (6) intervenção ou conquista por governo estrangeiro; (7) efeito bola-de-neve, ou seja, colapso ou derrocada dos sistemas democráticos de outros países. Um diagnóstico importante é o de que os processos de retrocesso democrático normalmente ocorrem por quem está no poder ou próximo a ele ${ }^{41}$.

Aqui encontramos um importante fundamento para a nossa pesquisa, o fato de a desconfiança nos valores democráticos, ou seja, o descrédito do povo nas instituições e nos representantes implicar em instrumento apto a conduzir, sobretudo democracias mais jovens instáveis, a regimes autoritários. Daí porque a busca por instrumentos de reforço democrático se apresentam importantes para análise.

Nota-se, que o trâmite histórico da democracia não corresponde a um processo de perene evolução, observando-se momentos de retrocesso, quase que como um corolário do

${ }^{38}$ HUNTINGTON, Samuel. P. A Terceira Onda. Op. Cit., pp. 30-34.

${ }^{39}$ Podem ser citados os casos da Tchecoslováquia em 1968, do Brasil em 1974, da Polônia em 1981 e da Turquia em 2017. PRZEWORSKI, Adam. Democracia e mercado: reformas políticas e econômicas no Leste Europeu e na América Latina. Rio de Janeiro: Relume-Dumara, 1994, p. 77.

${ }^{40}$ FUKUYAMA, Francis. "Why is Democracy Performing So Poorly?" In: DIAMOND, L. e PLATTNER, M. F. (eds.) Democracy in Decline? Baltimore: Johns Hopkins University Press, 2016, p. 11.

${ }^{41}$ HUNTINGTON, Samuel. P. A Terceira Onda. Op. Cit., pp. 30-34.

40 
sistema democrático, inábil a manter-se em constante processo evolutivo, em decorrência da própria insatisfação dos cidadãos com a ausência de evolução social agregada a certo reacionarismo, fruto de aversão ao processo de globalização que implica em diluição das fronteiras políticas, econômicas e culturais. E como já mencionado, não há como analisar a democracia e seus pressupostos em desconexão com o período histórico analisado ${ }^{42}$.

Por fim, vale mencionar que a democracia hoje encontra eco também em mecanismos de participação indiretas como movimentos sociais, instituições nãogovernamentais, associações civis, mídia e manifestações populares de rua. Embora prevaleça a democracia representativa, diversos instrumentos de exercício direto têm sido adotados como recall, iniciativa popular de lei, plebiscito e referendo. No item seguinte vamos nos debruçar um pouco sobre as características do regime democrático contemporâneo e em seguida tratar dos instrumentos de participação direta.

\subsection{Características do regime democrático contemporâneo.}

Pressupostos do regime democrático são os elementos sem os quais um regime não pode ser considerado efetivamente democrático. Em relação a esses pressupostos, Bobbio indica que deve existir: quanto aos sujeitos representantes, um número bastante elevado de membros, que serão regidos pela regra fundamental da maioria. Sobre os chamados a decidir ou escolher os representantes, devem ser colocados diante de alternativas reais de escolha, o que pressupõe a garantia dos direitos de liberdade, como livre opinião, expressão, reunião, associação, etc ${ }^{43}$. A observância destes pressupostos permite uma

42 Os próprios founding fathers da Constituição Norte-Americana cometeram falhas importantes na elaboração da constituição, se analisados os requisitos democráticos da contemporaneidade. Robert Dahl arrola estes elementos qualificando-os como antidemocráticos: (a) escravidão - não proibiu a escravidão e tampouco deu poder ao Congresso para fazê-lo; (b) sufrágio - não votavam as mulheres brancas, escravos, afro-americanos e indígenas; (c) eleição do presidente - propuseram que a escolha fosse isolada da população e do congresso. Um corpo de eleitores qualificados por serem detentores de saber e virtudes excepcionais escolheria o Chefe do Executivo. A sugestão foi rejeitada; (d) escolha dos senadores senadores deveriam ser escolhidos pelas assembleias e não pelo povo; (e) igualdade de representação no Senado - por meio do denominado "Acordo de Connecticut", cada estado passou a dispor do mesmo número de senadores, independentemente da população de cada unidade federativa; (f) Poder Judiciário - a constituição não restringiu os poderes do Judiciário referentes à declaração de inconstitucionalidade de leis, abrindo espaço para que o Poder Judiciário acabe por formular políticas públicas; (g) Poder do Congresso limitações de poderes que poderiam impedir o governo federal de regular ou controlar a economia. DAHL, Robert A. A Constituição Norte-Americana é Democrática? Op. Cit., pp. 23-26.

${ }^{43}$ BOBBIO, Norberto. O Futuro da Democracia. Op. Cit., pp. 32-33. 
maior aproximação dos ideais democráticos como a tolerância, não-violência e renovação gradual pelo debate de ideais ${ }^{44}$.

A separação dos poderes tem um forte sentido democrático, pois dividir o poder tende a impedir a concentração e, por conseguinte, o arbítrio, além de permitir que o povo influencie diretamente no governo. Assim, a seleção de governantes, de chefes, por meio de eleições, constitui o elemento central da democracia ${ }^{45}$.

O princípio da maioria assegura o grau mais elevado possível de liberdade política dentro da sociedade, o que não se confunde com o domínio absoluto da maioria, pois uma minoria, que atue em condições de igualdade, sempre poderá influenciar o pensamento da maioria. Esse entendimento é essencial à estabilidade dos regimes democráticos, havendo um verdadeiro compromisso no qual a solução de um conflito pela norma, ainda que não se adeque inteiramente aos interesses de uma parte, não afasta totalmente os interesses da outra $^{46}$. A ditatura da maioria também corresponde a um perigo, de modo que vontade da maioria não legitima a opressão à minoria. Portanto, a regra da maioria, inerente ao regime democrático, para se afastar da tirania, deve preservar e respeitar os direitos da minoria ${ }^{47}$.

Uma das principais características do processo democrático é a sua incerteza quanto aos resultados. Várias forças políticas competem pela preferência popular tendo como arena as estruturas democráticas. Se há incerteza quanto ao resultado de um lado, de outro a democracia demanda a existência de um sistema altamente regulado, cujas regras sejam claras e prévias, constituindo, por conseguinte, uma incerteza organizada (ruled open-endedness $)^{48}$. Desta forma, o povo assume um compromisso de, a despeito de desconhecer os vencedores do processo eleitoral, aceitar os resultados dele decorrentes, ainda que contrários à escolha de muitos de seus integrantes. Aliás, a aceitação do resultado pelos derrotados decorre da crença de que no futuro, valendo-se da mesma estrutura institucional, poderão novamente competir democraticamente e eventualmente atingir seus interesses.

Segundo Dahl devem ser analisadas cinco características para que se possa identificar se os membros de uma sociedade estão capacitados a decidir sobre a sua

${ }^{44}$ Idem, Ibidem, pp. 51-52.

${ }^{45}$ KELSEN, Hans. A Democracia. São Paulo: Martins Fontes, 1993, p. 91.

${ }^{46}$ KELSEN, Hans. Teoria Geral do Direito e do Estado (Tradução de Luís Carlos Borges). São Paulo: Martins Fontes, 1998, 3 Ed., pp. 410-411.

${ }^{47}$ TOCQUEVILLE, Alexis. A Democracia na América: leis e costumes (Tradução de Eduardo Brandao). São Paulo: Martins Fontes, 2001, pp. 294-296 e 304.

${ }_{48}$ PRZEWORSKI, Adam. Democracia e mercado: reformas políticas e economicas no Leste Europeu e na America Latina. Rio de Janeiro: Relume-Dumara, 1994, p. 29. 
política: (1) participação efetiva e igualitária de todos os membros de forma que estejam aptos a conhecer as opiniões sobre qual deveria ser a política adotada; (2) igualdade de voto; (3) entendimento esclarecido, os membros devem ter iguais oportunidades de aprender sobre as políticas e suas prováveis consequências; (4) controle do programa de planejamento, de modo que os membros devem ter a oportunidade de decidir como e quais questões devem integrar as políticas públicas; (5) inclusão dos adultos, permitindo-se o acesso a todos e não a pequenos grupos, de forma censitária ${ }^{49}$.

A inobservância de tais pressupostos implica na quebra da igualdade política, razão pela qual a democracia em grandes sociedades exige: (1) funcionários eleitos; (2) eleições livres, justas e frequentes; (3) liberdade de expressão; (4) fontes de informação diversificadas; (5) autonomia para associações; (6) cidadania inclusiva. Dahl reconhece que nenhum Estado jamais possuiu um governo que se adequasse perfeitamente a tais critérios de um processo democrático. Todavia, a análise dos pressupostos deve servir como horizonte a ser buscado visando a melhoria da qualidade democrática ${ }^{50}$.

Arend Lijphart descreve dois modelos de democracia fundados na reposta às questões sobre quem governa e no interesse de quem. No denominado modelo majoritário (majoritarian model ou westminester model) quem governa é a maioria e no interesse da maioria. Por outro lado, no modelo consensual (consensus model) governa o maior número de pessoas possível e no interesse do maior número de pessoas possível ${ }^{51}$.

${ }^{49}$ DAHL, Robert. Sobre a democracia. Op. Cit., pp. 49-50.

50 Das 34 guerras internacionais ocorridas entre 1945 e 1989 nenhuma ocorreu entre países democráticos, o que atesta que as democracias modernas não guerreiam entre si. Isso se deve ao comércio internacional, pois a dominação contemporânea não depende de tomada física de poder, mas da imposição comercial. RUSSETT, Bruce. Controlling the Sword: The Democratic Governance of National Security, Cambridge, Harvard University Press, 1990, Cap. 5, pp. 119-124.

${ }^{51}$ Embora ambos adotem o critério da maioria para decisões, o sistema majoritário é identificado em sociedades mais homogêneas e se caracteriza pelo bipartidarismo, com concentração do poder executivo nas mãos de um único partido, contentando-se com pequenas maiorias, sistema eleitoral majoritário e desproporcional, governos unitários e centralizados, flexibilidade constitucional e Banco Central controlado pelo Executivo. Como exemplo, Lijphart cita o Reino Unido, a Nova Zelândia e Barbados. De outro lado, o sistema consensual busca maior legitimidade em uma maior participação, dividindo o poder por meio de coalisões multipartidárias, equilíbrio de poder entre o Executivo e o Legislativo, sistemas multipartidários, representação proporcional, governos federais e descentralizados, forte bicameralismo, possibilidade de revisão constitucional (judicial review) e Banco Central independente. Parte-se do princípio de que a proteção de minorias, ou seja, dos grupos derrotados do pleito eleitoral, é pressuposto essencial da existência da democracia. É identificado em sociedades mais heterogêneas, na medida em que diferenças culturais, ideológicas, linguísticas, religiosas, étnicas e raciais demandam soluções mais consensuadas. Lijphart adverte que em sociedades assim, a sistema majoritário não é apenas não recomendado, mas perigoso, na medida em que minorias que constantemente tem o acesso ao poder negado, sentem-se excluídas e tendem a rejeitar a legitimidade do governo, como observado na Irlanda, na segunda metade do Século XX, no conflito entre a maioria protestante e a minoria católica. Como exemplos podem ser citados a Bélgica, o Brasil e, embora não se trate de uma nação soberana, os mesmos princípios e compartilhamento de poder se aplicam à União 
Podemos acrescentar também que um regime democrático contemporâneo deve ser pautado pela transparência (accountability) e pela responsividade (responsivess) a atuação do poder político, vinculadas aos interesses e expectativas da sociedade. Para que um governo seja responsivo às preferencias de seus cidadãos, deve garantir a eles oportunidade para: formular suas preferências e exprimir tais preferências, para que elas sejam consideradas na conduta do governo ${ }^{52}$. Para tanto, somente será possível que alguém formule e exerça preferências se dispuser de um mínimo de condições materiais que permitam satisfazer suas necessidades pessoais mais básicas, como condição para o exercício da democracia ${ }^{53}$.

Muitos estudiosos identificam outros requisitos ou elementos caracterizadores dos regimes democráticos na contemporaneidade, buscando um aprimoramento do sistema e a atualização histórica do instituto. Democracias modernas liberais congregam necessariamente três elementos, segundo Francis Fukuyama: (a) estado (state); (b) direito (rule of law); (c) transparência democracia (democratic accountability). Esta última, segundo o autor, consiste no governo que atua no interesse de toda a comunidade e não em seu próprio interesse privado. Portanto, o estado moderno busca uma atuação impessoal, em que o tratamento recebido pelas pessoas tem por fundamento a cidadania e não a relação pessoal de cada qual com integrantes do estado. Esse conceito de democracia moderna se opõe ao de estado neopatrimonial em que inexiste distinção entre o interesse público e o interesse privado da pessoa física do agente público ${ }^{54}$. O autor aponta ainda que é muito mais difícil transformar um estado patrimonialista ou neopatrimonialista em um estado moderno, transparente, que privilegie a accountability, do que transformar um estado de regime autoritário em democrático ${ }^{55}$.

\subsection{Desigualdade democrática: a democracia aparente.}

Europeia. LIJPHART, Arend. Patterns of Democracy: government forms and performance in thirty-six countries. 2nd ed. New Heaven/London: Yale University Press, 2012, pp 2-3; 10-18; 30-45.

${ }^{52}$ DAHL, Robert A. Poliarquia (Tradução: Celso Maduro Paciornick). São Paulo: EDUSP, 2015, p. 26.

53 "Não é possível falar em democracia em meio a indicadores econômicos-sociais que apontam para a linha (ou abaixo) da linha da pobreza. Uma grande dose de justiça social é condição de possibilidade da democracia”. STRECK, Lenio Luiz e MORAIS, José Luis Bolsan de. Ciência Política \& Teoria do Estado. Porto Alegre: Livraria do Advogado Editora, 7 Ed., 2012, p. 113.

54 FUKUYAMA, Francis. "Why is Democracy Performing So Poorly?" In: DIAMOND, L. e PLATTNER, M. F. (eds.) Democracy in Decline? Baltimore: Johns Hopkins University Press, 2016. pp. 1314.

\footnotetext{
${ }^{55}$ Idem, Ibidem, p. 12. 
Embora as estruturas democráticas, em tese, visem o acolhimento das várias forças políticas que competem entre si com caráter igualitário, existem diferentes graus de desigualdade, porquanto os grupos diferenciam-se na quantidade e qualidade de recursos econômicos, organizacionais e ideológicos. Esses fatores que possuem grande influência no processo democrático, especialmente na corrida eleitoral ${ }^{56}$.

O desequilíbrio eleitoral pode ser observado, por exemplo, na diferença de recursos financeiros para campanhas eleitorais, diferenças flagrantes de tempo de acesso a meios de comunicação pública, possibilidade de reeleição, acesso a emendas parlamentares, disseminação artificial e maciça de notícias falsas.

Os processos eleitorais na contemporaneidade são dominados pelo marketing político, com pouco espaço para o confronto de ideias e propostas ${ }^{57}$. Neste contexto, ganha relevo a possibilidade de os candidatos e agremiações arregimentarem valores para a elaboração de campanhas políticas. No Brasil são diversos os escândalos envolvendo o denominado Caixa 2 Eleitoral, que representa os recursos econômicos não contabilizados perante a Justiça Eleitoral e que servem às campanhas políticas.

A reeleição também representa um forte elemento de desigualdade democrática, pois estatisticamente, permite concluir que a possibilidade de um governante ser reconduzido é sempre muito maior do que de ser eleito caso não estivesse no poder, conforme já advertia Monica Herman Salem Caggiano ${ }^{58}$. A guisa de exemplo citamos, na América Latina, os seguintes casos em que o candidato à reeleição obteve sucesso no pleito eleitoral: Equador (Rafael Correa); Brasil (Dilma Rousseff); Colômbia (Juan Manuel Santos Calderón); Bolívia (Evo Morales) Venezuela (Hugo Chaves faleceu quando já exercia o terceiro mandato); Argentina (Cristina Fernández de Kirchner).

56 “Se as instituições democráticas são universalistas - isto é, neutras em relação à identidade dos participantes-, os que detêm maiores somas de recursos têm mais probabilidade de sair vencedores nos processos submetidos ao processo democrático". PRZEWORSKI, Adam. Democracia e mercado: reformas políticas e economicas no Leste Europeu e na America Latina. Rio de Janeiro: Relume-Dumara, 1994, pp. 26-27.

${ }^{57}$ FERREIRA FILHO, Manuel Gonçalves. A democracia no Limiar do Século XXI. São Paulo: Saraiva, 2001, p. 25.

58 "Em verdade, como assinalado no nosso Sistemas Eleitorais x Representação Política, o princípio decorre de interpretação extremamente restritiva do standard republicano que impõe a alternância, evitandose a perpetuação e a personificação do poder. (...) O continuísmo e o sempre presente perigo anunciado por Montesquieu, de que o poder corrompe o próprio poder, encontram-se como base a servir de respaldo à regra da inelegibilidade" CAGGIANO, Monica Herman S. A reeleição: tratamento constitucional (breves considerações). Preleções Acadêmicas, CEPS - Centro de Estudos Políticos e Sociais de São Paulo, Caderno 1, 1997, pp. 7/8. 
A desigualdade extrema e a deficiência educacional prejudicam a compreensão do eleitor e facilitam o aparecimento da figura do caudilho, líder carismático ${ }^{59}$. Por isso, a educação pode ser entendida se não como um pressuposto, uma exigência ontológica da democracia, na medida em que somente com determinado mínimo de conhecimento, o cidadão poderia ter condições de conhecer os candidatos, suas propostas, histórico, partidos políticos, e ainda, o conteúdo de determinadas questões que viessem a ser submetidas eventualmente a sua apreciação por meio de instrumento de democracia direta $^{60}$. O compromisso da cidadania com a democracia pressupõe o conhecimento político adequado, além de envolvimento nos assuntos públicos, impondo que os cidadãos tenham opiniões estáveis, consistentes e informadas sobre as principais questões públicas ${ }^{61}$.

Não se está aqui a cotejar a democracia como justiça social, pois podem existir regimes não-democráticos que possuem certo grau de distribuição de riquezas, bem como regimes democráticos com péssima distribuição. A igualdade social não constitui pressuposto para identificação de regimes democráticos. Trata-se de conferir um mínimo necessário, indispensável, no âmbito material e intelectual, que permita ao cidadão dedicarse, ainda que rápida e superficialmente, a compreender seu papel na construção de governos e na participação política, de modo a exercer em plenitude seus direitos políticos $^{62}$.

A liberdade, pedra de toque do regime democrático, tem, naturalmente, como pressuposto o mínimo necessário à subsistência, se analisada sobre um viés social e

\footnotetext{
59 “As desigualdades extremas na distribuição de recursos-chaves como renda, riqueza, status, saber e façanhas militares equivalem a desigualdades extremas em recursos políticos. Evidentemente, um país com desigualdades extremas em recursos políticos comporta uma probabilidade muito alta de ostentar desigualdades extremas no exercício do poder e, portanto, um regime hegemônico. (...) Se a condição de igualdade relativamente maior numa sociedade de agricultores livres for associada também a uma medida maior de igualdade política alocada através de sufrágio, partidos concorrentes, eleições e líderes responsivos, então a acumulação de desigualdades é ainda mais inibida. Ao acumular popularidade, seguidores e votos, os líderes podem compensar alguns dos efeitos potenciais das diferenças de riqueza e status, e usar os poderes reguladores do Estado para reduzir essas diferenças ou suas consequências na vida política" DAHL, Robert A. Poliarquia (Tradução: Celso Maduro Paciornick). São Paulo: Editora da Universidade de São Paulo, 2015, pp. 92-93.

${ }^{60}$ KELSEN, Hans. A Democracia. $1^{\circ}$ ed. São Paulo: Martins Fontes, 1993, p. 97.

61 MUNIZ, Carlos et al. “¿Están los políticos políticamente comprometidos?: Análisis del compromiso político 2.0 desarrollado por los candidatos a través de Facebook". Cuadernos info., Santiago, n. $39, \quad$ p. 135-150, $\quad 2016 . \quad$ dic. $\quad$ Disponível $\mathrm{em}$ $<$ https://scielo.conicyt.cl/scielo.php?script=sci_arttext\&pid=S0719-

367X2016000200009\&lng=es\&nrm=iso>. Acesso em $21 \quad$ de $\quad$ maio 2019. http://dx.doi.org/10.7764/cdi.39.970, p. 138.

${ }^{62}$ Direitos políticos implicam no poder de influenciar na vontade do Estado, sendo que o principal expoente é o direito de votar. KELSEN, Hans. Teoria Geral do Direito e do Estado. Op. Cit. p. 336. 
econômico $^{63}$. Em outras palavras, não há democracia onde a disseminação da miséria impede que boa parte da população possa ter conhecimento e compreensão mínimo do funcionamento da administração pública e da importância da representação política.

A liberdade política, porém, corresponde ao espaço de atuação em que a conduta do indivíduo não pode ser pautada por outras pessoas ou instituições, vale dizer, o indivíduo não é importunado por outros ${ }^{64}$. É necessário compreender que liberdade política não se confunde com outras questões, igualmente relevantes, mas de outra esfera, como igualdade, justiça, etc. A liberdade positiva representa o autogoverno, o desejo do cidadão de ser ele seu próprio amo ${ }^{65}$.

Outro elemento que importa em distorções no sistema de igualdade democrática são as chamadas emendas parlamentares, que vinculam de maneira indevida a pessoa física do parlamentar que indica a destinação da verba com a localidade que a recebe, e presta-se a instrumentalizar uma maior dependência do parlamentar em relação ao Poder Executivo, ao mesmo tempo que não contribui para a discussão da política pública, promovendo a personificação das políticas públicas.

Todas as dificuldades mencionadas nos conduzem a duas conclusões. A primeira, de que o regime democrático, mesmo sob o viés meramente procedimental, deve conter instrumentos que privilegiem a participação democrática igualitária e não apenas formal. A segunda, é que o sistema democrático demanda a todo o momento a criação de instrumentos que o aprimorem, exatamente para que as forças que militam contra a igualdade democrática possam ser contidas.

\subsection{Democracia x Tutoria.}

Crítico dos regimes democráticos, Brennan assevera que a democracia pode ser avaliada de duas maneiras, por meio de um caráter instrumental ou de forma simbólica. Ele exemplifica tais análises com a figura de um martelo e de um quadro. Enquanto o martelo é valorado por sua natureza instrumental, ou seja, presta-se a bater pregos, o quadro tem

${ }^{63}$ Embora tecnicamente um morador de rua dependente químico seja juridicamente livre, na prática sua liberdade não destoa muito apenas da liberdade negativa, já que pouco (ou nada) pode fazer com sua liberdade positiva. "Se argumenta, de forma convincente, que si um hombre es tan pobre que no puede permitirse algo que no está prohibido legalmente - uma barra de pan, um viaje alrededor del mundo o un recurso ante los tribunales-, entonces tiene la misma libertad que si la ley se lo prohibiera" BERLIN, Isaiah. Dos Conceptos de Libertad. El fin justifica los medios. Mi trayectoria intelectual (Traducción de Ángel Rivero). Madrid: Alianza Editorial, 2. Ed., 2014, pp. 61-63.

${ }^{64}$ Idem, Ibidem, pp. 62-63.

${ }^{65}$ Idem, Ibidem, p. 76. 
um valor sublime, que evoca em cada pessoa um sentimento, uma ideia. O autor assevera que alguns pensadores políticos veem a democracia por um viés instrumental, de modo que seu bom funcionamento tende a produzir relativamente bons resultados. Contudo, lembra que para outros, a democracia expressa a ideia de que todas as pessoas têm igual valor, de modo que a democracia seria um fim em si mesmo. Para ele, a democracia tem caráter puramente instrumental, e tal qual o martelo que pode ser substituído por outra ferramenta que seja mais eficaz na tarefa de bater pregos, deveríamos tentar substituir a democracia por governos com melhor performance ${ }^{66}$.

Nesta linha, o Filósofo Platão acreditava que o governo deveria ficar a cargo dos mais velhos e, dentre eles, os melhores e mais sábios (tutoria). Entretanto, a sabedoria não corresponderia ao único requisito para o governante, que deveria se mostrar solícito ao atendimento do interesse público e jamais ter se deixado contaminar por qualquer processo corruptivo $^{67}$.

Brennan propõe então a epistocracia, ou seja, o governo do conhecimento, em que o poder político é distribuído de acordo com a competência, habilidade e a boa-fé no exercício de tais habilidades. O autor arrola cinco formas de epistocracia: (a) sufrágio restrito - para adquirir o direito de votar e serem votados o cidadão deve ser aprovado em um processo em que comprovem sua competência e/ou o fato de estar suficientemente bem informado; (b) voto plural - todos os cidadãos têm direito a votar, mas apenas alguns, que se mostrem mais competentes ou muito bem informados, têm direito a votos adicionais; (c) loteria de emancipação - antes das eleições, milhares de cidadãos são escolhidos por sorteio e se tornam pré-eleitores. Porém, para ganhar o direito de voto, estes cidadãos devem participar de alguns exercícios e fóruns deliberativos; (d) veto espitocrático - as leis seguem o procedimento democrático regular, mas um grupo restrito, formado por pessoas com conhecimento, tem o poder de veto sobre a lei aprovada; (e) votação sopesada / governo por oráculo simulado - todo cidadão pode votar, mas no momento da votação responde também a um questionário relacionado a conhecimentos básicos de política. De

${ }^{66}$ BRENNAN, Jason. Against Democracy. Princeton: Princeton University Press, 2016, p. 11.

${ }^{67}$ PLATÃO. A República. São Paulo: Edipro, 2001, Livro III, p. 126-127. Sobre a razão pela qual Platão defendia que o controle político deveria estar sob a tutela de uma minoria, David Held lembra que Platão viveu sua juventude durante a Guerra do Peloponesso, na qual Atenas foi derrotada, gerando deterioração dos padrões de liderança, da moral e do direito, culminando com o julgamento e a morte de Sócrates em 399 a.c. HELD, David. Models of Democracy. Cambridge: Polity Press, 3 Ed., 2017, p. 23. 
acordo com a pontuação obtida no questionário, os votos dos cidadãos recebem um valor superior ou inferior ${ }^{68}$.

Neste ponto o autor realmente tem um ponto a ser considerado. Tomemos por exemplo a Lei da Ficha Limpa (Lei Complementar ${ }^{\circ}$ 135/2010), de iniciativa popular, que ampliou o rol de inelegibilidades, fazendo com que pessoas em determinadas situações jurídicas, fiquem privadas de sua capacidade eleitoral passiva por um determinado período, em razão, por exemplo, de condenação criminal, rejeição de contas pelo Tribunal de Contas, condenação por improbidade administrativa, etc. Note-se que, neste caso, adotando-se a tese de Brennan, o povo, diretamente inclusive, mercê do projeto de iniciativa popular, reconhecendo sua incapacidade de escolher de forma adequada seus representantes, cria regras para impedir, o próprio povo, de escolher como representantes, pessoas que não teriam condições de realizar um bom e probo governo, à luz de seu passado recente.

A tese de Brennan, porém, a nosso juízo falha em ao menos três pontos essenciais: (a) conhecimento não é sinônimo de melhor escolha política em prol do bem comum; (b) a existência de viés ideológico de eventual teste a ser aplicado e a legitimidade de quem o prepara; (c) bem comum ou da maioria não é um conceito unívoco ${ }^{69}$.

Parece-nos absolutamente falsa a premissa de que governantes mais sábios tem por norte a vontade geral e o bem comum e não seus interesses particulares e dos grupos a que estão ligados. Além disso, a proposta de realização de um teste para verificação de conhecimentos políticos básicos esbarra em dois problemas: quem ficará a cargo de preparação de tal teste, cujo rigor alterará a linha censitária do voto, e como se afastará do teste a discussão ideológica sobre o conteúdo das questões. Por fim, imagine uma região com baixo desenvolvimento econômico, com altos índices de analfabetismo e de utilização de um deficitário sistema público de saúde. Até que ponto um representante eleito que tenha de certa forma sentido diretamente os efeitos de tais problemas não estaria mais imbuído para resolver tais questões? Evidente que nada garante uma resposta positiva, mas por que tal população não teria direito de escolher uma pessoa em tal condição como representante, já que também não haveria garantia de que outra pessoa, ainda que profundo conhecedor dos sistemas de ensino e saúde, tutelaria o interesse comum dos mais

${ }^{68}$ BRENNAN, Jason. Against Democracy. Op. Cit., pp. 14-15.

69 "Não se questiona o fato de ser o melhor que deva comandar. Sobre isso estão de acordo tanto os que defendem a autocracia quanto os que defendem a democracia. O problema político-social é apenas saber de que modo o melhor ou os melhores podem chegar ao poder e mantê-lo". KELSEN, Hans. A Democracia. Op. Cit., p. 95. 
necessitados. Um representante com conhecimento técnico poderia dizer que o posto de saúde no bairro $\mathrm{X}$, atende um número muito pequeno de moradores, e seria mais racional eliminá-lo, mantendo apenas o posto de saúde do bairro Y. Tal medida concentraria gastos e permitiria um melhor equacionamento das contas públicas. De outro lado, o representante sem conhecimento técnico, poderia se insurgir contra a medida, dizendo que o bairro $\mathrm{X}$ é essencialmente pobre e rural e o transporte para o bairro $\mathrm{Y}$, além de restrito, imporia gastos que aquela população rural não tem condições de arcar.

$\mathrm{O}$ conceito de governo dos mais aptos, portanto, tomado em profundidade teria o potencial de aniquilar o conceito de democracia, a justificar um autoritarismo imposto por quem, exercendo o poder, se intitule o mais apto. Todavia, nos parece possível compatibilizar a eficiência administrativa, prezada pelo republicanismo, com a democracia. Não é necessário entender que à república sirvam apenas os governantes mais aptos, mas sim aqueles que atinjam um standard mínimo, naturalmente dentro de limites normativos. Assim, prevaleceria a democracia enquanto a governo do povo, exercido diretamente ou por representantes eleitos pela maioria. Porém, uma vez eleitos, os representantes devem apresentar certa performance, seja no aspecto moral, não praticando atos de improbidade, por exemplo, seja no âmbito da qualidade do exercício de seu governo, a vista de indicadores estabelecidos, especialmente os compromissos por eles próprios estabelecidos $^{70}$.

\subsection{Avaliação da qualidade democrática.}

A qualidade segundo Moles i Plaza constitui um fator de diferenciação que permite ganhar mercados ${ }^{71}$. Mutatis mutandis a avaliação da qualidade governamental à luz das propostas eleitorais, objeto de nossa pesquisa, poderá permitir àqueles que melhor cumprirem com suas propostas ganhar eleitores em um próximo pleito eleitoral.

A normatização com escopo na qualidade, no caso das empresas, pode se dar de duas formas. A primeira parte da própria empresa, entendendo-se exatamente que será ela a principal beneficiada com o cumprimento das metas de qualificação. A outra surge em

70 "Sob essa perspectiva, muito mais significativa do que a escolha de pessoas sábias e especialmente qualificadas para o exercício da função pública é a seleção de pessoas que saibam identificar e que se comprometam a respeitar a opinião e a vontade dos eleitores”. LISOWSKI, Telma Rocha. Mandato Parlamentar \& Crise de Representatividade: instrumentos de perda e reforma do sistema. Curitiba: Juruá, 2018, p. 186.

${ }^{71}$ MOLES Y PLAZA, Ramon J. Derecho y calidad: El régimen jurídico de la normatización técnica. Barcelona: Ariel, 2001, p. 24. 
razão da necessidade, já que a ausência de uma certificação ou um selo de cumpridora de normas pode fechar o mercado a determinadas empresas ${ }^{72}$.

A verificação da qualidade democrática de diferentes países é mais complicada do que na esfera privada, encontrando óbices a dificultar a tarefa comparativa, como o tamanho da população, a diversidade cultural, a riqueza relativa da população, etc. Deste modo, a diferença de grandeza populacional entre Estados Unidos e Islândia, bem como de riqueza entre Haiti e Brasil naturalmente não permitem o transporte de soluções simplistas para a identificação da qualidade dos regimes democráticos.

Segundo Robert Dahl, o processo de democratização de um país pode ser analisado essencialmente por meio de duas variáveis - a possibilidade de contestação pública e o direito de participação-, que prestam-se a classificar o nível de democratização dos países. Segundo o autor, nenhum regime é plenamente democrático, mas aquelas sociedades que mais se aproximam deste ideal, as poliarquias, são aquelas em que há ampla popularização (inclusivas), ou seja, grande participação social, e são vastamente abertos à contestação pública (liberalizadas). Já o grau mínimo democrático corresponderia a uma hegemonia fechada, caracterizadas pela baixa inclusividade e pequena possibilidade de contestação. Entre ambas podem ser encontradas as hegemonias inclusivas, com grande participação social, mas com baixa liberalização, e as oligarquias competitivas, um grau acima, em que embora possuam baixa participação social, tem grande possibilidade de contestação ${ }^{73}$.

Lijphart, em seu estudo acerca do sistema democrático em trinta e seis países, questionou a premissa de que a qualidade governamental estaria em oposição à alta qualidade democrática, apontando que a democracia consensual, cujos instrumentos não são difíceis de implementar nas constituições, apresentam apenas vantagens em relação ao sistema majoritário. Eventuais resistências adviriam de tradições culturais e institucionais contra o sistema consensual. O autor menciona, a guisa de exemplo, que na América Latina existe uma cultura política amplamente sedimentada na ideia de uma representação proporcional e sistemas presidencialistas ${ }^{74}$.

A representação democrática tem sede essencialmente por meio dos partidos políticos, que são as agremiações que reunem as pessoas que têm afinidade com

${ }^{72}$ MOLES Y PLAZA, Ramon J. Op. Cit., p. 25.

${ }^{73} \mathrm{O}$ autor arrola sete conjuntos de condições que tornam a aproximação à poliarquia mais ou menos provável: sequências históricas; a ordem socioeconômica; o nível de desenvolvimento socioeconômico; igualdades e desigualdades; pluralismo subcultural; dominação por um poder estrangeiro e crenças de ativistas políticos. DAHL, Robert A. Poliarquia. Op. Cit., pp. 30-31 e 190-191.

${ }^{74}$ LIJPHART, Arend. Patterns of Democracy: government forms and performance in thirty-six countries. 2nd ed. New Heaven/London: Yale University Press, 2012, p 296-299. 
determinados objetivos sociais e econômicos. Muitos são os problemas com os programas destes partidos, que serviriam exatamente para orientar ideológica e pragmaticamente os eleitores. Os programas partidários, assim como as propostas eleitorais que estudaremos mais à frente, por exemplo, são quase sempre genéricos, e limitam-se a alguns alicerces principiológicos que não guardam relação com a atuação direta dos partidos. A generalidade acaba por permitir aos líderes partidários manejar seus programas de acordo com os ventos reinantes nas eleições, mas impede os eleitores de identificarem de maneira clara as características de sustentação dos partidos.

Ainda em relação à qualidade democrática, cabe distinguir conceitualmente as denominadas democracias delegativas das democracias representativas.

A democracia delegativa consiste em uma maneira de conceber o exercício do poder político que, embora apresente o preenchimento de determinados requisitos democráticos, decorrente de eleições razoavelmente limpas e competitivas e certas liberdades políticas básicas, como liberdade de expressão, reunião, associação e ação, representa uma forma menor de democracia, deficitária em muitos de seus aspectos. Surge em sociedades com grande fragmentação, tanto social, como das instituições estatais, que enfrentam crises nacionais de percepção generalizada de tamanha gravidade, a justificar a existência de um Poder Executivo forte e hostil a controles relacionados a accountability $^{75}$. O Chefe do Poder Executivo, que vitorioso no processo eleitoral desfruta de certo messianismo diante da população, encarna a própria ideia de nação, e à vista de um cenário de grave crise, passa a invocar poderes cada vez maiores para conduzir o país rumo à retomada de crescimento. Diante disso, emergem críticas aos mecanismos de accountability, na medida em que indevidamente estariam limitando o exercício do poder por aquele que demanda medidas extremas para a superação da crise ou para impedir que ela retorne ${ }^{76}$. Em síntese, a adjetitvação delegativa representa a transmissão tácita de imensos poderes ao governante eleito, de modo que ele poderia tensionar critérios de

75 A accountability consiste em diversos tipos de controles institucionais que visam efetivar a prestação de contas e a responsabilização dos representantes políticos. Sobre o tema Bruno Lorencini aponta que a accountability tem a prestação de contas como um ponto de partida, mas abrange também à transparência, como principal valor democrático. LORENCINI, Bruno. Democracia Qualificada e Responsabilidade Política. São Paulo: LiberArs, 2018, p. 265-266.

${ }^{76}$ Para tanto o controle ou a forte influência sobre os meios de comunicação se apresenta como importante ferramenta para manutenção do apoio social ao governo forte, sobretudo calcado no fato de que as opiniões contrárias ao governo implicam em dificultar a gestão de salvação nacional que estaria em curso. O'DONNELL, Guillermo. Nuevas Reflexiones acerca de la democracia delegativa (DD). In: O'DONNELL, Guillermo; IAZZETTA, Osvaldo; QUIROGA, Hugo (coord.) Democracia delegativa. Buenos Aires: Prometeo Libros, 2011, pp. 19-25. 
legalidade, transparência e responsividade, diante de suposta necessidade de restauração da situação de normalidade e ordem pública.

Difere-se da democracia representativa, melhor analisada no capítulo seguinte, em que embora também exista uma delegação de poder aos representantes, tal delegação está limitada a controles constitucionais e legais, confinando o espectro de poder do governante. Por esta razão as democracias delegativas podem se tornar regimes autoritários, conforme paulatinamente vão se desfazendo os mecanismos de accountability, o que pode ser observado na Venezuela, Turquia e Hungria.

Diante de uma tentativa de golpe militar em julho de 2016, Recep T. Erdogan, presidente da Turquia, em abril de 2017, submeteu à população um referendo, no qual por apertada margem, foi aprovada a transformação de sistema de democracia parlamentar para um sistema presidencialista, extinguindo-se o cargo de primeiro-ministro, sob o argumento de que a expansão dos poderes do presidente era necessária em razão dos tempos de crise. $\mathrm{Na}$ Hungria foi aprovada a criação de uma nova corte constitucional, com início de funcionamento previsto para janeiro de 2020, com atribuição para alguns casos que envolvam assuntos adminstrativos, cujos integrantes serão integralmente indicados, promovidos e correcionados exclusivamente pelo Ministro da Justiça.

Ainda visando analisar a qualidade democracia, Leonardo Morlino indica três critérios: (a) viés procedimental - a qualidade resulta de um processo realizado de forma específica e controlado; (b) viés estrutural - o predicado reside em características específicas do produto, focando em seu conteúdo, como por exemplo, no seu design, no seu funcionamento; (c) viés consequencial - consiste na receptividade expressa pelo destinatário, pelo cliente. Já não importa o procedimento ou o conteúdo, mas sim o resultado, a satisfação do consumidor ${ }^{77}$.

Em relação ao procedimento, analisam-se três fatores: a informação; a justificação, ou seja, as razões declinadas pelos governantes para a prática dos atos; e a punição, que representa a compensação que resulta da resposta realizada pelos eleitores ou por qualquer ato do poder público. A accountability vertical situa-se exatamente nesse julgamento político realizado pelo corpo eleitoral, na medida em que periodicamente ele recompensa o candidato renovando o voto ou, ao revés, o punindo, deixando de votar novamente nele ou

77 MORLINO, Leonardo. "Teoria da Democratização, Qualidade da Democracia e Pesquisa de Opinião: Ainda em 'Mesas Separadas"'. In: MOISÉS, José Alvaro. (org.) Democracia e Confiança - Por que os Cidadãos Desconfiam das Instituições Públicas? São Paulo: Editora Universidade de São Paulo, 2010, pp. 34-35. 
no partido político que ele integra. Sobre o aspecto substantivo, a qualidade democrática demanda a observação dos critérios de liberdade, respeito à expansão dos diretos em suas diferentes dimensões, e a igualdade, a busca pela maior implementação de igualdade nas esferas política, econômica e social. Por fim, em relação ao aspecto consequencial, discutese se as decisões políticas vão ao encontro das aspirações do corpo social, vale dizer, se os governos são capazes de implementar políticas públicas que efetivamente atendam às reivindicações sociais. Tal prerrogativa é denominada de responsividade

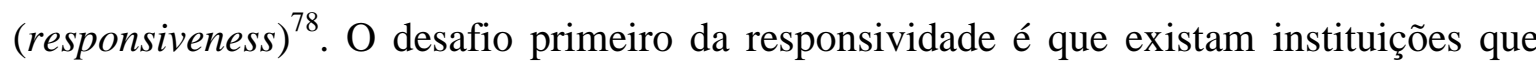
possam, de alguma forma, colher e condensar a manifestação dos representados, sob a forma de opiniões, interesses e preferências, para então sancionar aqueles que se afastarem dessas manifestações ${ }^{79}$.

Identificados elementos relacionados a critérios utilizados para nortear a qualidade democrática, passamos aos desafios contemporâneos enfrentados pelos regimes democráticos.

\subsection{Desafios democráticos na contemporaneidade.}

A democracia não deve ser encapsulada ao mero reconhecimento de direitos e liberdades formais, ao exercício do poder de voto periódico e à existência de divisão e limites aos poderes públicos. O reconhecimento formal de direitos é o primeiro pressuposto a quem não detêm direitos e almeja implementá-los, mas neles não se encerrm.

A existência de eleições periódicas surge como direito, a quem até então se via privado do sufrágio. A divisão de poderes é um grande avanço para quem vivia sob o jugo autoritário. Após a Segunda Guerra Mundial, os povos que conviveram neste cenário almejavam apenas viver em paz, ter uma residência e poder trabalhar para prover a própria subsistência.

Entretanto, com a paulatina sedimentação e implementação de tais direitos, as gerações que se desenvolveram neste cenário naturalmente passaram a questioná-los e a buscar maior efetividade. Assim, a democracia passa a demandar não apenas um rol de

${ }^{78}$ Difere, portanto, da accountability horizontal ou interinstitucional, na qual os governantes são controlados por outras instituições que tem habilitação técnica, além de expertise e legitimidade para realizar a atividade de controle. MORLINO, Leonardo. "Teoria da Democratização, Qualidade da Democracia e Pesquisa de Opinião: Ainda em 'Mesas Separadas"”. Op. Cit., pp. 35-37.

${ }^{79}$ LISOWSKI, Telma Rocha. Mandato Parlamentar \& Crise de Representatividade: instrumentos de perda e reforma do sistema. Curitiba: Juruá, 2018, p. 77. 
direitos, mas que eles sejam efetivamente colocados em prática e expandidos. Os países em desenvolvimento demandam muito mais serviços públicos do Estado para que sejam superadas estruturas que reproduzem o atraso e a desigualdade. Assim, o simples ato de votar não é mais suficiente. É necessário que as eleições sejam limpas e os candidatos tenham iguais oportunidades para se submeterem ao sufrágio, diante de regras previamente estabelecidas. A divisão de poderes passa a demandar não apenas um controle recíproco, mas o efetivo ingresso do povo como agente de governo, orientando as políticas públicas e decisões mais relevantes. As gerações que se sucederam à Segunda Grande Guerra não mais aspiram apenas prover a própria subsistência, mas desenvolver todas as suas potencialidades enquanto seres humanos, com educação de qualidade, lazer, consumo de bens e serviços, meio-ambiente equilibrado, etc.

O advento do fenômeno da globalização, especialmente a partir da última década do Século XX, permite identificar que partidos de orientação social-democrata passaram a inclinar-se no sentido de posições mais liberais no aspecto econômico, aderindo ao discurso de abertura econômica global. Diante de tal fenômeno, parte dos eleitores destes partidos, especificamente a população com menor acesso a educação e com maiores dificuldades econômicas, de forma paulatina e crescente, tem apresentado insatisfação com a representação política, não se sentindo devidamente representada. Em alguns países esse sentimento de insatisfação tem desbordado, refletindo na rejeição a imigrantes, que supostamente seriam corresponsáveis pelas dificuldades econômicas enfrentadas e por representarem uma ameaça à cultura nacional. Por consequência, a insatisfação extravasa ao próprio funcionamento do sistema democrático ${ }^{80}$. Manuel Castells aponta que a rejeição não é ao regime democrático em si, mas à democracia liberal, tal qual existente em cada país, clamando-se por uma "democracia real" ${ }^{81}$. Pesquisa realizada pelo Latinobarômetro demonsta que na América Latina houve sensível queda no apoio ao regime democrático foi de $61 \%$ no ano 2010 para $48 \%$ em 2018 , enquanto no mesmo período, a indiferença com relação ao regime, passou de $16 \%$ para $28 \%$. No Brasil, a aprovação no ano de 2017 era de

${ }^{80}$ Outra consequência desse fenômeno é o crescimento da aderência deste extrato social aos partidos políticos de inclinação populista, seja de orientação à esquerda ou à direita. AARTS, Kees, THOMASSEN, Jacques e VAN HAM, Carolien. "Globalization, Representation, and Attitudes towards Democracy". In: THOMASSEN, Jacques (editor) Elections and Democracy. Michigan: Oxford University Press, 2014, pp. 205-206.

${ }^{81}$ CASTELLS, Manuel. Ruptura: a crise da democracia liberal (Trad. Joana Angélica d’Ávila Melo). Rio de Janeiro: Zahar, 2018, p. 8. 
$43 \%$, baixando para $34 \%$ no ano seguinte. Em relação ao nível de satisfação com o grau atual de desenvolvimento democrático atual, apenas $9 \%$ estão satisfeitos ${ }^{82}$.

Entre os desafios democráticos atuais listamos a demanda por rapidez na tomada de decisões, a promoção por maior equidade social, o desinteresse pela coisa pública gerando a necessidade de uma educação para a cidadania ativa, a crise de representatividade e o combate à inclinações antidemocráticas.

Levitsky e Ziblatt desenvolveram quatro critérios de alerta para a identificação de um regime democrático sob ataque, inclinando-se a um regime autoritário, à luz do comportamento de seus líderes políticos, que seriam voltados aos seguintes comportamentos: (a) por meio de condutas e discursos rejeitam as regras do jogo democrático; (b) negam legitimidade a seus concorrentes; (c) toleram ou estimulam a violência; (d) mostram-se dispostos a restringir as liberdades civis de seus oponentes e de condutas para limitar o livre exercício da imprensa ${ }^{83}$.

Oferecer respostas sociais mais rápidas representa uma demanda social compatível com a velocidade das mudanças contemporâneas, mas por vezes incompatível com a necessidade de discussão em nível profundo demandado pelo parlamento e pela esfera política como um todo ${ }^{84}$. A lentidão inerente aos poderes públicos e ao debate político em face de uma sociedade que demanda por soluções instantâneas tem gerado um afastamento ainda maior dos membros da sociedade com a política e seus agentes ${ }^{85}$. É certo, contudo, que a referida lentidão pode ter seu lado bom, na medida em que se impede a edição de leis de ocasião, elaboradas de forma irrefletida por vezes em razão do desejo de responder a fatos imediatos e de maneira populista.

${ }^{82}$ Disponível em: < http://www.latinobarometro.org/lat.jsp >. p. 16 e 34. Acesso em 21/05/2019.

83 LEVITSKY, Steven e ZIBLATT, Daniel. Como as democracias morrem (Tradução Renato Aguiar). Rio de Janeiro: Zahar, 2018, p. 32.

84 "Se conseguirmos controlar o poder, isso se deve em grande parte ao fato de a democracia funcionar, na prática, como um mecanismo de redução de velocidade, de filtragem e decantação dos processos de poder. Do ponto de vista da velocidade em que atua, a democracia implica em um processo de tomada de decisão mais lento e hesitante e, do ponto de vista de sua esfera de ação a democracia implica em um leque de decisões bastante restrito". SARTORI, Giovanni. A Teoria da Democracia Revisitada. São Paulo: Ática, 2. Ed., 1994, p. 226.

85 "A instantaneidade (anulação da resistência do espaço e liquefação da materialidade dos objetos) faz com que cada momento pareça ter capacidade infinita; e a capacidade infinita signifique que não há limites ao que pode ser extraído de qualquer momento - por mais breve e "fugaz" que seja. O "longo prazo" ainda que continue a ser mencionado, por hábito, é uma concha vazia sem significado (...). O "curto prazo" substituiu o "longo prazo" e fez da instantaneidade seu ideal último. Ao mesmo tempo em que promove o tempo ao posto de contêiner de capacidade infinita, a modernidade fluida dissolve - obscurece e desvaloriza - sua duração. BAUMAN, Zygmunt. Modernidade Líquida (Trad. Plínio Dentzien). Rio de Janeiro: Jorge Zahar Ed., 2001, p. 145. 
A democracia impõe que a decisão seja tomada em um determinado tempo. Este limite temporal, após a realização de razoável e discussão por um período de tempo, é que garante a imparcialidade e aceitação da regra da maioria ${ }^{86}$. Por isso, Bobbio apontava que a democracia tem a demanda fácil e a resposta difícil, enquanto a autocracia tem a demanda difícil, mas maior possibilidade de dar respostas rápidas ${ }^{87}$.

As democracias não têm conseguido corresponder à demanda social por serviços públicos de qualidade. A frustração constante das expectativas gera a frustração com o regime que o sustenta. É preciso novamente lembrar que a democracia não é uma panaceia que se presta a resolver problemas como pobreza, violência, inflação, corrupção, desigualdade social, preconceito, etc. Assim, o fracasso de governos democraticamente eleitos para a solução de problemas desta grandeza tem contribuído para o descrédito das instituições democráticas e a frustração dos cidadãos. Democracia, logo, é uma solução para o problema da tirania, mas não necessariamente a outros problemas ${ }^{88}$.

Villegas lembra que as constituições latino-americanas comumente apresentam extenso catálogo de ilusões acerca de uma sociedade melhor e mais justa almejada para o futuro, representando mais símbolos políticos do que efetiva limitação de poder ou consagração efetiva de direito ${ }^{89}$.

Os países da América Latina têm sofrido com a incapacidade dos governos de prover serviços básicos de qualidade, como educação, saúde, segurança e infraestrutura ${ }^{90}$. Ao analisar, como exemplo, o Afeganistão e o Iraque nota-se que após a invasão e ocupação norte-americana foram organizados nestes países processos democráticos eleitorais. Contudo, não houve em tais países a evolução para o desenvolvimento de estados modernos, pois não puderam defender seu território de inimigos externos, sofrendo invasões e dominação parcial de território por parte do Estado Islâmico, bem como não conseguiram entregar serviços públicos de qualidade, mercê de elevados graus de corrupção no governo ${ }^{91}$.

Em outro flanco, a política tem deixado de ser a atividade em que os problemas privados coletivos se tornam questões públicas ou questões de natureza publicista se

${ }^{86}$ NINO, Carlos Santiago. La constitución de la democracia deliberativa. Barcelona: Gedisa Editorial, 1997, p. 167.

${ }^{87}$ BOBBIO, Norberto. O Futuro da Democracia. Op. Cit., p. 49.

${ }^{88}$ HUNTINGTON, Samuel. P. A Terceira Onda. Op. Cit., p. 257.

${ }^{89}$ VILLEGAS, Mauricio Garcia. "Constitucionalismo Aspiracional: Derecho, Democracia y Cambio Social en América Latina”. Revista Análisis Politico. Bogota, v. 25, ed. 75, p. 91, maio-agosto, 2012.

${ }^{90}$ FUKUYAMA, Francis. Why is Democracy Performing So Poorly?. Op. Cit., p. 16.

${ }^{91}$ Idem, Ibidem, p. 15. 
tornam questões privadas. A agenda de questões públicas tem ficado circunscrita aos problemas privados de figuras públicas, no dizer de Zygmunt Bauman, de modo que as tradicionais questões políticas democráticas, ou seja, o modo como os governantes exercem seus deveres públicos em direção ao bem-estar individual e social, perde relevância e vai desaparecendo, tendo seu espaço preenchido pelas questões privadas relacionadas aos governantes. A sociedade passa a buscar exemplos e não líderes aptos a conduzir um determinado agrupamento à melhoria do bem-estar social ${ }^{92}$. Por isso, nada pior para o Estado do que cidadãos que deixam de se interessar pelas coisas públicas ${ }^{93}$.

O espetáculo, segundo Guy Debord, representa um modelo da vida dominante na sociedade contemporânea, em que as imagens e as manchetes facilmente se sobrepõem ao conteúdo real transmitido. O espetáculo impõe-se como uma relação social entre pessoas, mediada por imagens ${ }^{94}$. Embora não se trate de um fenômeno recente, a evolução tecnológica das últimas décadas potencializou esse modelo. Como desdobramento desta premissa, a falta de coercibilidade das propostas contribui para a alienação dos eleitores, pois as propostas eleitorais atuam à margem da realidade prática, sem qualquer preocupação com o que realmente pode ou não ser implementado, visando apenas saciar o que o eleitor espera ${ }^{95}$.

Portanto, o indivíduo passa a se preocupar quase que exclusivamente com seus problemas pessoais, que devem ser enfrentados com suas próprias ferramentas individuais, limitando a isso a esfera publicista. Há uma grande dificuldade do indivíduo de ter empatia com os demais cidadãos em relação a problemas que não lhe afetam de forma direta. Por exemplo, aqueles cujos filhos têm acesso a escolas e planos de saúde particulares pouco se

${ }^{92}$ Um exemplo lapidar é o caso do presidente norte-americano Bill Clinton, em que seu affair com uma funcionária gerou maior repulsa social do que atos políticos que teriam sido praticados em seu governo e que poderiam ser questionados na esfera pública. BAUMAN, Zygmunt. Modernidade Líquida. Op. Cit., pp. $84 / 85$.

93 "Sitôt que le service public cesse d'être la principale affaire des citoyens, et qu'ils aiment mieux servir de leur bourse que de leur personne, l'Etat est déjà près de sa ruine. (...) Sitôt que quelqu'un dit des affaires de l'Etat, que m'importe? on doit compter que l'Etat est perdu." ROUSSEAU, Jean-Jacques. Le Contrat Social. Paris, 1851, Livro III, Cap. XV, p. 16.

${ }^{94}$ DEBORD, Guy. A sociedade do espetáculo (Trad.: Estela dos Santos Abreu). Rio de Janeiro: Contraponto, 1997, p. 14.

95 "A alienação do espectador em favor do objeto contemplado (o que resulta de sua própria atividade inconsciente) se expressa assim: quanto mais ele contempla, menos vive; quanto mais aceita reconhecer-se nas imagens dominantes da necessidade, menos compreende sua própria existência e seu próprio desejo. Em relação ao homem que age, a exterioridade do espetáculo aparece no fato de seus próprios gestos já não serem seus, mas de um outro que os representa por ele. É por isso que o espectador não se sente em casa em lugar algum, pois o espetáculo está em toda parte". Idem, Ibidem, p. 24. 
interessam e envidam poucos esforços efetivos pela melhoria de tais serviços na esfera pública. O Estado passa a perder importância ${ }^{96}$.

Held lembra que o poder político é compartilhado entre atores de âmbito nacional, regional e internacional. Segundo o autor, a continuidade da legitimação da democracia não pode mais ficar limitada às fronteiras estatais, devendo a democracia cosmopolita potencializar o desenvolvimento de capacidades administrativas e recursos políticos de forma independente em escala regional e global, porém, como complemento necessário a politicas locais e nacionais ${ }^{97}$. Como exemplos podem ser lembradas a União Européia, a Organizacao das Nações Unidas e a Organização Mundial do Comércio. Se de um lado a assertiva impressiona, no sentido de ampliação do espectro democrático, de outro lado, a regulação coletiva, independentemente do acerto técnico de decisões, acaba por engessar, em certo grau, o poder político interno dos países. Tal situação pode gerar a sensação de ineficiência democrática à coletividade, que se vê impedida de tomar determinadas medidas, ainda que correspondam à vontade popular e do próprio governante.

Não necessariamente surgirá uma nova ordem mundial que substitua a democracia liberal em crise, conforme adverte Manuel Castells, ao lembrar que da ruptura da relação institucional entre governantes e governados pode simplesmente se instalar o caos, ainda que um "caos criativo", mesmo que a ser descoberto ${ }^{98}$.

Ainda no século XVIII, Montesquieu apontava que o poder da educação é indispensável no governo republicano, no qual a virtude política consiste na renúncia aos próprios interesses em prol do amor às leis e à pátria, que consiste na supremacia do interesse público em face do interesse privado ${ }^{99}$.

O caminho para a criação de um espírito democrático é a educação. Os cidadãos não devem ser tratados apenas como objeto passivo da legislação, mas como agentes autônomos que fazem parte dos governos de sua própria sociedade. As razões de decidir devem ser acessíveis a todos a quem elas são dirigidas. A deliberação deve ser pública e não apenas na reserva mental do governante, o que inclusive contraria a concepção de que

96 Sobre essa questão Bauman adverte: "Em um Estado que não é mais ponte segura além do confinamento da mortalidade individual, um chamado ao sacrifício do bem-estar individual, para não falar da vida individual, em nome da preservação ou da glória imorredoura do Estado soa vazio e cada vez mais bizzarro, se não engraçado" BAUMAN, Zygmunt. Modernidade Líquida. Op. Cit., p. 213.

${ }^{97}$ HELD, David. Models of Democracy.. Cambridge: Polity Press, $3^{\circ}$ Ed, 2017, pp. 291-292.

98 CASTELLS, Manuel. Ruptura: a crise da democracia liberal (Trad. Joana Angélica d'Ávila Melo). Rio de Janeiro: Zahar, 2018, pp. 144/145.

${ }^{99}$ MONTESQUIEU, Charles de Secondat. De l'esprit des loi. Paris: Vve Dabo, 1824, Livro IV, Cap. 5, pp. 66-67. 
o representante reflete isoladamente sobre o que, na opinião dele, é o melhor para a sociedade. Nos dedicaremos ao tema da representação no capítulo seguinte.

Neste cenário cabe ainda mencionar a crise de representatividade, na qual o cidadão não consegue identificar que os representantes estão alinhados em buscar o que é melhor para a sociedade, mas sim a tutela de interesses individuais próprios. Os escândalos de corrupção, de seu turno, podem nesta linha gerar dois tipos de reações distintas, o desinteresse total pela política e pela democracia, que ontologicamente não funcionariam ou a possibilidade de identificação dos políticos que devem ser alijados do sistema por não se mostrarem merecedores de confiança popular manifestada pelo voto ${ }^{100}$.

Ao realizar severa critica às premissas que fundamentam o regime democrático representativo, Brennan afirma que a participação política não é realidade para a maioria das pessoas, que na verdade, tendem a ser imobilizadas e corrompidas pela democracia. Para ele o direito de votar ou de se candidatar não constitui uma liberdade fundamental, diferentemente da liberdade de expressão, religião e associação. Por tal razão, rejeita a ideia de que a democracia é a única forma justa de governo, em oposição apenas a regimes totalitários e autoritários. O autor encerra sua crítica dizendo que "o sufrágio universal incentiva a maioria dos eleitores a tomar decisões políticas de uma maneira ignorante e irracional, e então impõe estas decisões ignorantes e irracionais a pessoas inocentes" ${ }^{101}$.

Brennan não é categórico ao afirmar que a epistocracia, o governo dos que tem maior conhecimento, seria melhor do que a democracia, mas que, diante dos pífios resultados obtidos pela democracia, a tentativa seria válida. Como exemplo ele cita as leis de proteção ambientais que tem por escopo nos proteger de nossa própria conduta possa vir a degradar o meio ambiente. Partindo dessa premissa ele questiona por que não seria legítimo regular a votação - sob o aspecto qualitativo - para nos proteger de nós mesmos. Menciona, ainda, o fato de que as crianças e adolescentes menores são proibidas de votar exatamente porque se presume que não tenham conhecimento suficiente para votar de forma consciente e sábia. Neste caso não faria sentido excluir também os maiores que igualmente não tivessem o mesmo conhecimento?

Diante de tais insatisfações e falta de respostas para os problemas apresentados ocorre o flerte nostálgico com os regimes autoritários, não se distinguindo o

${ }^{100}$ Sobre o tema ver o nosso Corrupção Política: Mecanismos de Combate e Fatores Estruturantes no Sistema Jurídico Brasileiro. Belo Horizonte: Del Rey, 2016.

101 “(...) universal suffrage incentivizes most voters to make political decisions in an ignorant and irrational way, and then imposeses these ignorant and irrational decisions on innocent people". BRENNAN, Jason. Against Democracy. Princeton: Princeton University Press, 2016, pp. 7-8. 
descontentamento com o governo do método de seleção política. Quando os cidadãos não acreditam nos governantes eleitos, as bases fundantes do regime democrático passam a ser questionadas. Os cidadãos começam a questionar a própria validade do sistema em $\mathrm{si}^{102}$.

Entretanto, cabe anotar que a legitimidade dos regimes democráticos não depende apenas de seu desempenho. A estabilidade democrática demanda que as elites políticas, ou seja, o centro pujante de poder que abarca líderes políticos, empresariais e militares, autem conjuntamente para resolver problemas sociais graves, sem pretender explorar tais fatos em benefício próprio. Na Espanha, por exemplo, os ataques terroristas promovidos pelo grupo separatista basco ETA não foram utilizados para retirar a legitimidade do regime democrático $^{103}$. Mas ainda que não se considere o flerte com o autoritarismo ${ }^{104}$, a ausência de resposta aos desafios democráticos que não permite que se avance na consolidação e aprimoramento do sistema democrático já é razão bastante para que se identifique a necessidade de aprimoramento. Os problemas contemporâneos enfrentados pela qualidade democrática implicam em desafios para a sustentação e implementação do próprio regime.

A insatisfação da cidadania com a democracia começa com a perda de confiança nas pessoas e nas estruturas que conformam o poder político. Há uma clara percepção de recuo democrático no mundo contemporâneo, vale dizer, de redução dos índices de qualidade democrática. Sinais de alerta podem ser identificados em países em que ao menos alguns elementos democráticos têm apresentado recrudescimento, como Venezuela, Tailândia, Turquia, Hungria, Brasil e Polônia ${ }^{105}$. Cabe a reflexão se estaria sendo gestada uma terceira onda reversa, na esteira dos ensinamentos de Huntington.

Se o regime democrático possui tantas falhas, cabe mesmo a indagação se a democracia é o melhor regime. Robert Dahl reconhece que nos regimes democráticos também são praticadas injustiças e abusos, mas afirma tratar-se do regime mais desejável $^{106}$. Neste sentido, estamos de acordo com a frase atribuída a Winston Churchill

${ }^{102}$ LEVITSKY, Steven e ZIBLATT, Daniel. Como as democracias morrem. Op. Cit., p. 189.

${ }^{103}$ HUNTINGTON, Samuel. P. A Terceira Onda. Op. CIt., p. 254.

104 "Enquanto nas democracias consolidadas os cidadãos críticos orientam sua desconfiança política primordialmente para a adoção de novos modelos de participação e mesmo para a reforma do sistema representativo, nas novas democracias a desconfiança de parlamentos, partidos políticos, sistema judiciário e serviços públicos, está associada com sentimentos negativos sobre a política, baixos níveis de participação ou de interesse por assuntos públicos e até a preferência por modelos democráticos que descartam os parlamentos e os partidos políticos". MOISÉS, José Alvaro. "Democracia e Desconfiança das Instituições Democráticas". In: MOISÉS, José Alvaro. (org.) Democracia e Confiança - Por que os Cidadãos Desconfiam das Instituições Públicas? São Paulo: Editora Universidade de São Paulo, 2010, pp. 45-46.

${ }^{105}$ LEVITSKY, Steven e ZIBLATT, Daniel. Como as democracias morrem. Op. Cit.,, p. 194.

${ }^{106} \mathrm{O}$ autor elenca as razões pelas quais a democracia possui consequências desejáveis: (1) evitar a tirania; (2) direitos essenciais; (3) liberdade geral; (4) autodeterminação; (5) autonomia moral; (6) 
no sentido de que a democracia é o pior dos regimes, com exceção de todos os outros já experimentados.

Traçando um paralelo entre a política e as relações consumeristas, a política passa a ser um produto a ser consumido tanto quanto diversos outros da sociedade de consumo ${ }^{107}$. Atualmente a política é vista como um produto sujo, com poucos aplicativos, que invariavelmente não funciona direito e que não pode ser substituído senão após um longo período.

É interessante observar como a legislação consumerista oferece grande proteção ao consumidor de produtos e serviços, sobretudo no que tange à transparência das características dos produtos e serviços, ao passo que a democracia, pedra de toque da liberdade, tutela muito pouco os direitos do eleitor em relação ao conteúdo da campanha eleitoral e a exigibilidade das propostas ${ }^{108}$. Assim, infelizmente identifica-se que se está diante de um eleitor (consumidor), que não gosta do produto (a política), e apenas terá interesse em participar ativamente acaso se sinta seduzido e identifique sua importância.

desenvolvimento humano; (7) proteção aos interesses pessoais essenciais; (8) igualdade política; (9) busca pela paz; (10) prosperidade. DAHL, Robert. Sobre a democracia. op. cit., 2001, p. 58.

${ }^{107}$ Os membros da sociedade pós-moderna são essencialmente consumidores e não produtores. Os produtores buscam um mínimo necessário à subsistência, embora possam naturalmente sonhar com mais, desde que em conformidade com um determinado limite social. Os consumidores, por sua vez, não possuem limite, a sedução por mais não possui um ponto de limite, ainda que moral. Atingido um desejo, imediatamente deve se voltar para o próximo. Essa diferenciação, extraída da obra de Bauman, traz um feliz exemplo que associa nos produtores a busca pela saúde enquanto que nos consumidores o desejo é de se tornar cada vez mais fitness, pois a saúde não é bastante. É necessário diminuir ainda mais o percentual de gordura corporal, aumentar a massa magra, ainda que tais índices não sejam os ideias segundo a Organização Mundial de Saúde. BAUMAN, Zygmunt. Modernidade Líquida. Op. Cit., 2001, p. 91.

108 "Así como existe la protección legal del consumidor con el fin de impedir que sea victima de especulación o engano publicitário, por parte de los comerciantes e industriales, así mismo es necessária la defensa del elector frente a la propaganda política que pretenda conducirle a votar sin darle razones que sean pertinentes desde el punto de vista programático e ideológico. La propaganda electoral deve ser regulada con el fin de que se limite a la información acerca de los programas de acción gubernamental y fines ideológicos de los partidos, a la identificación, de los candidatos a la Presidencia de la República e a los cuerpos deliberantes, sin añadir calificativos y descalificaciones personales y a la invitación a votar". DÍAZ, Angel Eduardo Alvarez. "Los contenidos de la propaganda electoral y la protecction de la racionalidad politica del elector". In: MAGALlanES, Manuel Vicente (coord.) Propaganda Política Partidos y Sistema Electoral. Consejo Supremo Electoral, Colección del Cincuentenario 2. Caracas: Miguel Angel García e Hijo, s.r.l.: 1987, pp. 97-98. 


\section{VINCULO POLÍtiCO-ELEITORAL E A INSUFICIÊNCIA DOS MECANISMOS DE CONTROLE}

A compreensão do vínculo político-eleitoral que se estabelece nas democracias ocidentais é de crucial importância para a discussão do tema de fundo da pesquisa, qual seja, a aferição e exigibilidade das promessas de campanha.

A cidadania representa a base da participação política democrática, e na clássica lição de Marshall "é um status concedido àqueles que são membros integrais de uma comunidade", ainda que não se saiba quais são esses direitos, pois cada sociedade historicamente idealiza e concretiza o objeto dos direitos essenciais, conforme suas idiossincrasias $^{109}$. Integrar a sociedade representa, entre outros elementos, fazer parte do processo de formação do governo, como candidato ou eleitor. As eleições, entretanto, não bastam. É indispensável que existam canais institucionais de manifestação popular bem como instrumentos de controle para punir aqueles que tergiversaram no uso do domínio conferido pelo mandato.

Neste passo, é necessário que se conheçam, em primeiro lugar, as teorias políticas relacionadas à representação política. As teorias políticas sofrem naturalmente o efeito da ideologia, ou seja, os grupos sociais elaboram proposições de forma a conformar seus interesses e ideias. Por isso, na teoria política existe uma tendência a não diferenciar a hipótese da conclusão. A ciência política é, portanto, parcialmente ideológica. Os estudiosos que afirmam que seu estudo é totalmente objetivo incidem em confusão entre ideologia implícita e o sistema vigente da natureza das coisas, conforme lembra Duverger $^{110}$. Isso, porém, não afasta a necessidade de buscar com toda a força possível, elementos que mais aproximem o estudo de um método e de resultados alijados de questões ideológicas.

Neste capítulo, portanto, trataremos da natureza do vínculo que se estabelece entre o representante e o representando, os mecanismos de participação democrática direta e, por fim, os instrumentos de controle da representação existentes e se eles tem se mostrado suficientes e eficazes.

\footnotetext{
109 MARSHALL, T. H. Cidadania, classe social e status. Rio de Janeiro: Jorge Zahar Editores, 1967, p. 76.

${ }^{110}$ DUVERGER, Maurice. Institutions Politiques et Droit Constitutionnel - Les grands système politiques.. Paris: Presses Universitaires de France, $12^{\circ}$ Ed., 1971. t. 1, pp. 445-46.
} 


\subsection{A representação política.}

A representação política surge no Século XVIII, na Inglaterra, com a consagração do parlamento como poder político, de modo que o povo, representado na Câmara dos Comuns, passava a ter participação na confecção das leis e da ação governamental.

O constitucionalismo liberal estabeleceu um espaço dual entre cidadãos e representantes produzidos pela eleição. A competição eleitoral teria por pressuposto duas virtudes, ensinar os cidadãos a governar a si próprios de forma pacífica e, ao mesmo tempo, poder se fazer presente como participantes do jogo eleitoral para representar a si próprios, enquanto povo ${ }^{111}$. Em síntese, trata-se da capacidade eleitoral ativa (possibilidade de votar) e a capacidade eleitoral passiva. Há, contudo, um paradoxo nestas visões, pois ao mesmo tempo em que a vontade popular é fator de legitimação do poder, presume-se que o representante tomará decisões racionais, desde que se proteja da opinião popular, de modo que o representante deveria ignorar a opinião pública para ser um bom governante.

Algumas questões comportam análise: a representação tem por escopo a tutela da coletividade ou os melhores interesses do país, da nação? O voto é um dever ou um direito?

Francisco Suárez, em lição clássica, já apontava que a soberania encontrava-se no povo, e indicava que a comunidade só existiria quando houvesse um governo político e organização adequada. Do contrário não haveria uma coletividade, mas apenas um aglomerado de homens e não se atingiria o fim ontológico da sociedade, que é a busca do bem comum ${ }^{112}$. A delegação do poder não representa alienação ou mesmo transmissão ilimitada das competências.

Em sentido oposto, pela "teoria da soberania nacional", a supremacia pertence à nação e não mais à soma dos indivíduos. Esta teoria reduz o poder individual e das eleições. O representante eleito não tutela, portanto, a soma dos interesses individuais, mas os interesses nacionais ${ }^{113}$.

\footnotetext{
${ }^{111}$ URBINATI, Nadia. Representative Democracy. Chicago: University of Chicago Presse, 2006, p. 26.

112 SUÁREZ, Francisco. De Legibus (III 1-16) DE Civili Potestate. Edición crítica bilíngue por Luciano Pereña. Corpus Hispanorum de Pace. Madrid: Consejo Superior de Investigaciones Científicas, 1975, vol. V, pp. 24-25.

113 'Si la nation est titulaire de la souveraineté, et non les citoyens qui la composent, le pouvoir électoral n'est attribué à ceux-ci qui en qualité d'organes charges de designer les représentants de la nation. 
$\mathrm{Na}$ formação da vontade geral do povo, porém, a coletividade não deve ser encarada apenas pela atomização dos indivíduos, mas também de forma orgânica, pelos grupos profissionais ${ }^{114}$. Assim, no século XVIII, a eleição prestava-se a fortalecer a classe profissional dos governantes, mercê da legitimação decorrente do escrutínio eleitoral, enquanto aos cidadãos cabia apenas aceitar ou recusar o governante, mas nunca interferir na atividade governamental ${ }^{115}$.

Abade Siyès aponta que o exercício de uma função pública é um "dever" e não um "direito", na medida em que o representante recebe a confiança dos representados para, em nome destes, exercer sua representação ${ }^{116}$. Kelsen, de seu turno, caracteriza a representação política como um "direito", semelhante ao direito privado, que deve, portanto, corresponder a um dever, que consiste em os órgãos públicos encarregados da eleição aceitarem o voto do cidadão e tratá-lo de acordo com os preceitos da lei, proclamando vencedor aquele que, segundo as regras eleitorais vigentes, sagrou-se vencedor. Neste aspecto, Kelsen anota que sob a perspectiva da função dentro do processo de criação do Direito, não há diferença fundamental entre o direito privado e o direito público, pois ambos autorizam que o titular participe da criação da ordem jurídica, da "vontade do Estado"117.

Para Rousseau o problema do Estado Ideal corresponde ao próprio problema da democracia em "encontrar uma forma de associação que defenda e proteja qualquer membro a ela pertencente e na qual o indivíduo, mesmo se unindo a todos os outros, obedeça apenas a si mesmo e permaneça livre como antes" ${ }^{118}$. A verdadeira democracia, que rigorosamente segundo o autor jamais existiu, demandaria um Estado muito pequeno, com simplicidade de costumes, com grande igualdade em condições de riquezas e pouco ou nada de luxo ${ }^{119}$.

(...) Le suffrage n'est pas nécessairement universel. DUVERGER, Maurice. Institutions Politiques et Droit Constitutionnel - Les grands système politiques. Op. Cit., p. 102.

${ }^{114}$ KELSEN, Hans. A Democracia. São Paulo: Martins Fontes, 1993, p. 62.

115 URBINATI, Nadia. Representative Democracy. Chicago: University of Chicago Presse, 2006, pp. $25-27$

${ }^{116}$ SIYÈS, Abade. Exposição Refletida dos Direitos do Homem e do Cidadão (Organização, estudo introdutório e tradução de Emerson Garcia). São Paulo: Atlas, 2015, p. 97.

${ }^{117}$ KELSEN, Hans. Teoria Geral do Direito e do Estado. Tradução de Luís Carlos Borges.. São Paulo: Martins Fontes, $3^{\circ}$ ed, 1998, pp. 126-127.

118 "Tradução nossa: "Trouver une forme d'association qui défende et protège de toute la force commune la personne et les biens de chaque associe, et par laquelle chacun, s'unissant à tous, n'obéisse pourtant qu'à lui-même, et reste aussi libre qu'auparavant? "Tel est le problème fondamental dont le Contrat social donne la solutidn". ROUSSEAU, Jean-Jacques. Le Contrat Social. $1^{\circ}$ ed. Paris, 1851, Livro I, Cap. VI, p. 3

${ }^{119}$ Idem. Ibidem, p. 3. 
Kelsen é bastante incisivo ao afirmar que em uma democracia representativa o povo participa apenas da formação do governo, e não de seu exercício, de modo que a vontade do Estado derivaria apenas da vontade dos representantes e não no sentido de que a vontade dos representantes refletiria a vontade popular ${ }^{120}$. Segundo ele não é possível representar uma vontade, pois "aquele que delega, abdica". Portanto do ponto de vista ideológico a democracia se sustentaria em impossibilidades lógicas intrínsecas ${ }^{121}$.

Nesta linha Salamanca aponta que o afastamento da imperativividade do mandato não gerou representantes livres, mas mandatários de grandes grupos de poder e capital, em troca de apoio em eleições ${ }^{122}$.

\subsection{Natureza jurídica do vínculo político-eleitoral: mandato imperativo $\mathbf{x}$ representação clássica.}

Uma primeira e importante indagação, portanto, acerca do mandato político diz respeito a identificar se o mandatário tem o dever de cumprir aquilo que dele espera o mandante. E caso a resposta seja positiva, qual seria o fundamento para tanto. Para Monica Herman Salem Caggiano, trata-se de identificar a transmutação do poder político, ou seja, quem é representado no processo eleitoral que "fotografa o momento em que o titular do poder se manifesta sobre a composição do organismo a quem é atribuído o exercício deste poder" ${ }^{\prime 23}$.

Antes da Revolução Francesa de 1789 os representantes dos corpos políticos eram agentes reais escolhidos por classe ou grupos profissionais, que deveriam cumprir as instruções recebidas, sob pena de ter o mandato cassado. Com a Revolução, foi abolido o

120 “O votante toma parte apenas na criação de um órgão - parlamento, Chefe de Estado - cuja função é criar a vontade do Estado, as normas jurídicas; e as normas jurídicas que esse órgão em de criar normas gerais, estatutos”. KELSEN, Hans. Teoria Geral do Direito e do Estado. Op. Cit., p. 127.

${ }_{121}^{12}$ KELSEN, Hans. A Democracia. Op. Cit., p. 92.

122 "La meta de representantes sabios e independientes era difícil de combinar em un mundo moderno en el que había intereses particulares muy intensos alimentados por la libertad del capital y la concentración de la riqueza. Luego de la desaparición del mandato imperativo, la posición del mandante no quedó vacía por mucho tempo: en esta nueva y deformada versión del mandato el dinero y otras fuentes de poder comenzaron a ocuparla. Los representantes libres dejaron de serlo para convertirse esta vez en mandatários de quienes promovían com grandes capitales sus carreras, o de los grupos de poder a quienes prometían su representación a cambio de algún apoyo en las elecciones, o de los lobbies que, justo al contrario, les prometían um apoyo electoral futuro a cambio de sua representación, les prometían un apoyo electoral futuro a cambio de sua representación actual" SALAMANCA, Felipe Rey. Voto Programático y Programas de Gobierno en Colombia. Bogotá: Universidad del Rosario, Facultad de Jurisprudencia, 2015, pp. 23-24.

${ }^{123}$ CAGGIANO, Monica Herman S. Sistemas Eleitorais x Representação Política. São Paulo: Centro Gráfico do Senado Federal, 1987, p. 20. 
caráter imperativo dos mandatos, sob o argumento de que o representante tutelaria não apenas um distrito em particular, mas toda a nação ${ }^{124}$.

O representante deve fazer o que querem seus representados ou agir como melhor lhe parecer para tutelar o bem-estar dos representados? A resposta à questão naturalmente imporá a utilização de pressupostos teóricos de cada corrente que pretende defende-la. Segundo Pitkin, um teórico do mandato sustentará que o representante atua como um agente dos representados, devendo manter-se alinhado a suas instruções, não tendo recebido "poderes ditatoriais". De outro lado, teóricos da independência do representante afirmrão que a política tem objeto difícil e complexo, de modo que é melhor que a expertise política do eleito seja levada em consideração, em detrimento da vontade dos eleitos, o que ao final melhor tutelaria seus interesses. Ademais, não se poderia impor primeiro a decisão para depois permitir sua discussão ${ }^{125}$.

Estar representado tem o sentido de estar presente, de alguma forma, ainda que não de maneira literal. Mas a melhor resposta à questão colocada parece ser a que busca compor os paradoxos existentes nas duas teorias. Ao mesmo tempo em que o representante deve poder atuar de forma independente, os representados devem poder atuar de alguma maneira. A existência de conflitos entre representantes políticos e representados é inerente à representação e não por isso invalida sua base teórica. Não haveria sentido se os representados não pudessem ser capazes de expressar sua vontade e de atuar de forma efetiva. Ptikin desloca o foco da análise da teoria da representação para o interesse e esclarece que o representante deve tutelar o bem-estar dos representados. Haverá interesse quando houver algo em jogo, ou seja, quando houver escolhas a serem feitas e neste sentido importará saber o que desejam aqueles a quem corresponde o interesse tutelado ${ }^{126}$. Portanto, mais importante do que a forma, seria a finalidade da representação: a promoção do interesse do representado.

Acerca da representação dois temas são especialmente sensíveis: "poderes" do representante e "conteúdo" da representação. No que toca aos poderes, a democracia representativa evoluiu de uma representação delegada, em que o representante age em

${ }^{124}$ Kelsen lembra que antes da Revolução Francesa de 1791 os representantes dos corpos políticos eram agentes reais escolhidos por classe ou grupos profissionais, que deveriam cumprir as instruções recebidas sob pena de ter o mandato cassado. Com a Revolução foi abolido o caráter imperativo, sob o argumento de que o representante tutelaria não apenas um distrito em particular, mas toda a nação. KELSEN, Hans. Teoria Geral do Direito e do Estado. Op. Cit., p. 415.

${ }^{125}$ PITKIN, Hanna Fenichel. El Concepto de Representacion. Madri: Imprenta Fareso, 1985, pp. $159-160$.

${ }^{126}$ Idem, Inidem, p. 170. 
nome do representado e sobre sua orientação (mandato imperativo), e uma representação fiduciária, na qual o representante tem liberdade para agir em nome dos representados, mas de acordo com seu próprio discernimento. Em relação ao conteúdo, o representante pode atuar no interesse geral de todos os cidadãos, abarcando também aqueles que não votaram nele, ou apenas no interesse particular de um determinado grupo ou classe profissional. Contemporaneamente a representação é tida, em seu conteúdo, como dos interesses gerais da sociedade, daí porque inclusive o representante não pode ser responsabilizado por seus eleitores em particular.

A própria denominação "representação" sofre severas críticas de Kelsen, que a aponta como considerável enfraquecimento do princípio da autodeterminação política. Uma verdadeira relação entre representantes e representados implicaria não apenas na eleição da formação do órgão, seria necessário que o representante estivesse “juridicamente obrigado a executar a vontade dos representados, e que o cumprimento dessa obrigação seja juridicamente garantido". Kelsen conclui afirmando que os autores que insistem em caracterizar o governo moderno como "representativo", apesar da total independência do eleitorado, e criticam o mandato imperativo, na verdade, não apresentam uma teoria científica para tanto, mas apenas uma ideologia política ${ }^{127}$.

$\mathrm{O}$ mandato representativo contemporâneo corresponde à teoria da soberania. O mandatário nao é ligado aos representantes por um mandato preciso, nos moldes do Direito Civil, mas à nação, de tal sorte que ele se exprime de acordo com sua consciência acerca do que é melhor para a nação e não necessariamente o que anseiam seus eleitores. Isso, segundo já alertava Duverger, transfere o poder político para as mãos de uma oligarquia de deputados, alijando as massas da efetiva participação política ${ }^{128}$. Portanto, rejeita-se a ideia de um mandato imperativo, que tinha lugar no período pré-revolucionário, e no qual o representante se obrigava a fielmente seguir as instruções dos representados, sob pena de ter o seu mandato revogado ${ }^{129}$.

${ }^{127}$ KELSEN, Hans. Teoria Geral do Direito e do Estado. Op. Cit., pp. 413-414 e 416.

${ }^{128}$ DUVERGER, Maurice. Institutions Politiques et Droit Constitutionnel - Les grands système politiques. Op. Cit., p. 103-104.

129 "Il correspondent à la souveraineté et à la représentatif fractionnées. Il transpose exactement em droit public la conception du mandat de droit privé. La désignation des députés est um mandat de donné par les électeurs aux élus d'agir em leurs lieu et place. Le mandataire doit se conformer strictment aux instructions de son mandant. Il reçoit de lui um mandat 'impératif' e duverger'". Idem, Ibidem, p. 103. 
Entretanto, Bobbio afirma que a norma constitucional historicamente mais violada é a da proibição do mandato imperativo na representação política ${ }^{130}$. Como consequência haveria hoje um grupo de interesses contrapostos, como representantes das indústrias e dos operários, ou seja, as denominadas bancadas temáticas. Além do recorte apresentado por Bobbio, que trata da representação dos grupos sociais por meio de suas bancadas, há também aqueles parlamentares que ilicitamente passam a integrar determinados grupos de interesse. A Operação Lava-Jato, no Brasil, demonstrou o volume de aporte financeiro realizado por empreiteiras à campanha de candidatos em todas as esferas de poder e de distintos matizes ideológicos, sem qualquer escopo republicano, e com o objetivo de garantir acesso a um limitado e seleto grupo de empresas e pessoas para a celebração de negócios públicos e orientação de legislação de seu interesse. Na prática, tratava-se de um exercício de mandato voltado à imperatividade ilícita.

A representação, segundo análise de Nadia Urbinati, tem sido observada por três perspectivas: jurídica, institucional e política. As duas primeiras aproximam-se por seu caráter formalista e por estarem baseadas no relacionamento entre Estado e Pessoa. A teoria jurídica é a mais antiga e dela teria derivado a teoria institucional. A concepção jurídica recebe esta denominação por associar a representação a um contrato privado de comissão, ou seja, a autorização para que o representante realize uma ação que o representado é detentor do poder de realizar por si. O modelo jurídico evidencia, pois, uma lógica individualista e não-política no tratamento da representação, de modo que ela não é associada à representatividade e à eficácia. Assim, a teoria jurídica permitiu que se justificasse de forma funcional a representação, que passou a ser a base dos governos representativos liberais. A teoria institucionalista foca o ente político estatal e relega a sociedade ao juízo do representante. A função do eleitor limita-se a "legitimar a nomeação" dos políticos profissionais ${ }^{131}$.

Os polos existentes nesta seara são a "delegação" (instrumentos vinculativos), representada pelas ideias de Rousseau e a "alienação" (incumbência ilimitada), teorizada

\footnotetext{
130 “Quem representa interesses particulares tem sempre um mandato imperativo. E onde podemos encontrar um representante que não represente interesses particulares?" BOBBIO, Norberto. O Futuro da Democracia (Trad. Marco Aurélio Nogueira). São Paulo: Paz e Terra, 2000, p. 37.

${ }^{131}$ URBINATI, Nadia. Representative Democracy. Chicago: University of Chicago Presse, 2006, pp. 20-23. Para Schumpeter a democracia é um "sistema institucional para chegar a decisões políticas, no qual os indivíduos adquirem o poder de decidir por meio de uma luta competitiva pelo voto". A principal função do eleitorado é formar o governo. As volições coletivas, mais ou menos vigorosas, somente ganham vida quando líderes políticos resolvam transformá-las em fatos políticos. SCHUMPETER, Joseph A. Capitalismo, Socialismo e Democracia (Tradução Luiz Antônio Oliveira de Araújo). São Pulo: Editora Unesp, 2017, pp. 366-369.
} 
por Sieyès ${ }^{132}$. O representante não é um porta-voz da vontade do grupo representado, mas alguém com conhecimento para decidir, por ele próprio, em nome dos representados, em seu interesse ${ }^{133}$. As teorias jurídicas e institucionalista surgiram e se desenvolveram antes da transformação democrática da sociedade e do Estado, razão pela qual são pouco permeáveis $^{134}$.

Como lembra Nadia Urbinati, analisar a consistência democrática da representação necessariamente impõe que se analise a soberania popular e o tipo de participação que ela presume. O povo passa a ter um poder negativo que consiste na possibilidade de investigar, julgar, influenciar e reprovar os governantes e legisladores ${ }^{135}$.

A representação política, por sua vez, passa a analisar o aspecto dinâmico e não estático da representação, diferenciando-se das teorias anteriores. A representação deixa de ser assemelhada a um contrato privado, não pertencendo mais aos representantes e instituições governamentais, passando a descrever um processo político no qual existe uma recíproca troca entre as instituições e a sociedade, não limitada à deliberação e às decisões legislativas. A teoria consolida-se no Século XX, com a expansão do sufrágio e com o crescimento da opinião pública e da vida associativa ${ }^{136}$.

A conclusão de Nadia Urbinati em relação à teoria política é no sentido de que a presença física imediata (direito ao voto) está intrinsecamente ligada a uma presença ficta mediata (direito à livre expressão e à livre associação), refletindo um constante embate entre a política da presença e a política das ideias ${ }^{137}$. É o que ensiava Agesta, ao asseverar que a representação é antes de tudo uma via de participação na qual os membros representados influem nas decisões de seus representantes, articulando os interesses e

${ }^{132}$ URBINATI, Nadia. Representative Democracy. Op. Cit.,2006, pp. 21-22.

${ }^{133}$ Para Abade Sieyès o mandatário exerce a representação de forma livre em relação ao mandante, não havendo, portanto, um "mandato imperativo", mas sim representação clássica, pois ele representa a toda a nação e não apenas a seus eleitores. "O direito de pensar, de querer e de agir pessoalmente é inalienável: pode-se, apenas cometer o seu exercício àqueles que tenham nossa confiança e essa confiança tem por característica essencial o fato de ser livre" SIYÈS, Abade. Exposição Refletida dos Direitos do Homem e do Cidadão. Op. Cit., p. 97.

${ }^{134}$ URBINATI, Nadia. Representative Democracy. Op. Cit., p. 22-23.

${ }^{135}$ Idem, Ibidem, pp. 28-29.

${ }^{136}$ Idem, Ibidem, p. 24.

137 "The multiple sources of information and the varied forms of communication and influence that citizens activate through media, social movements and political parties set the tone of representation in a democratic society by making the social political. They are constitutive componentes of representation, not accessories, Will and judgment, immediate physical presence (the right to vote) and a mediated idealized presence (the right to free speech and free association) are inextricably intertwined in a society that is itself a living confutation of the dualism between the politics of presence and the politics of ideas since all presence is an artifact of speech". Idem, Ibidem, p. 25. 
opiniões de um agrupamento social ${ }^{138}$. Além disso, o povo passa também a dispor de um poder negativo em relação ao representante, que consiste na possibilidade de investigar, julgar, influenciar e reprovar os governantes e legisladores ${ }^{139}$.

A representação política democrática é, portanto, o instrumento em que os governantes são eleitos pelos cidadãos e considerados como seus representantes para a tutela de interesses comuns. Contudo, o governo "para o povo" não pode ser um elemento distintivo da democracia, na medida em que governo autocrático pode ser um governo que, mesmo à míngua de liberdade, seja voltado em alguma medida ao bem comum. O "governo do povo" é aquele em que o povo participa direta ou indiretamente de um governo exercido por decisões majoritárias de uma assembleia popular ou corpo ou corpos de indivíduos eleitos pelo povo ${ }^{140}$.

A ideia de representação como atuação própria, ou seja, em que o represente atua como se estivesse atuando o representado, embora bastante próxima do escopo de governo democrático, apresenta algumas dificuldades, como essencialmente identificar a vontade do representado, ou seja, a vontade da maioria dos eleitores, voltada ao bem comum.

Sobre os obstáculos de identificar o bem comum como objetivo a ser perseguido, Schumpeter aponta três dificuldades. A primeira consiste na impossibilidade de consenso sobre seu objeto. A segunda, ainda que a primeira fosse superada e fosse viável, definir o bem comum, esbarraria nas diferentes percepções quantos aos meios para o atingimento do objeto consensual. Por fim, em decorrência da impossibilidade de superação das duas primeiras dificuldades, desapareceria o conceito de bem comum ${ }^{141}$.

De qualquer forma, a crença de que o representante atua em nome do bem comum é por demais pueril e utópica, como bem advertia Espinosa, enquanto houver homens haverá vícios $^{142}$. Parece existir um grande distanciamento entre o idealismo de liberdade e participação igualitária, que norteou racionalmente o constitucionalismo e que serve de sustentação à democracia, e a efetiva experiência prática, decorrente da realpolitik.

253.

${ }^{138}$ AGESTA, Luis Sanchez. Princípios de Teoría Política.Madrid: Editora Nacional, 3. E.d, 1970, p.

${ }^{139}$ URBINATI, Nadia. Representative Democracy. Op. Cit., p. 28-29.

${ }^{140}$ KELSEN, Hans. A Democracia. Op. Cit., pp. 141-142.

${ }^{141}$ SCHUMPETER, Joseph A. Capitalismo, Socialismo e Democracia. Op. Cit., pp. 341-342.

142 "Com efeito, [os filósofos] concebem os homens não como são, mas como gostariam que fossem. De onde resulta que, as mais das vezes, tenham escrito sátira em vez de ética e que nunca tenham concebido política que possa ser posta em aplicação (...) se crê que em todas as ciências que têm aplicação, mormente a política, a teoria é discrepante da prática, considera-se que não há ninguém menos idôneo para governar uma república do que os teóricos ou filósofos". ESPINOSA, Baruch de. Tratado Político (Trad. Intr. e notas Diogo Pires Aurélio). São Paulo: WMF Martins Fontes, 2009, pp. 5-6. 
Porém, ontologicamente não necessariamente o melhor interesse dos representados corresponderá a seus desejos diretos e imediatos ${ }^{143}$. Por isso, o representante deveria se guiar pelo que os representados "deveriam desejar" para a tutela do melhor interesse coletivo. Em síntese, o representante não teria que obedecer sempre aos representados, mas deveria sempre buscar ouvir e compreender suas manifestações ${ }^{144}$.

Em um segundo nível a discussão passa a abarcar os partidos políticos, para que se identifique se o representante eleito deve ou não seguir as diretrizes de sua agremiação. Os partidos políticos possuem um programa nacional e, ao eleger candidatos a eles vinculados, o eleito, integrante do Poder Executivo ou do Poder Legislativo, conecta-se a este programa diante de seus deveres como integrante do partido e porque, presume-se, acredite que o interesse nacional e local estará mais preservado de acordo com as diretrizes desta agremiação.

A ideia que gostaríamos de sedimentar neste momento é que a representação pode ser identificada como potência ou como ação. No primeiro caso se esgotaria na eleição e no segundo implica em vínculo perene e intercomunicador entre representante e representado. A nosso juízo, portanto, a representação deve ser inserida como um processo político dinâmico, e que, embora se oponha ao paradigma contratual do mandato imperativo, não se basta na escolha procedimental do representante, que governaria totalmente alforriado de seus compromissos e dos anseios da população. Evidentemente o desafio está em identificar em que medida deve-se - e pode-se - objetivar e tutelar tais aspirações.

\subsection{Tentativas de reaproximação com o mandato imperativo.}

A vista da crise de representativa vigente, no qual os eleitores em geral observam um abismo entre seus interesses e a conduta dos parlamentares, alguns movimentos tem ocorrido no sentido de prestigiar instrumentos híbridos, que permitam, em certa medida, um retorno a uma imperatividade dos mandatos, com controle sobre o conteúdo direto das manifestações políticas dos representantes.

Na Argentina o Partido de La Red (Partido de Rede La Rioja) tem em seu estatuto o compromisso de que seus representantes eleitos votarão de acordo com o que os cidadãos

${ }^{143}$ ACHEN, Christopher. H. e BARTELS, Larry M. Democracy for realists Why Elections Do not Produce Responsive Government. Princeton: Princeton University Press, 2016, p. 54.

${ }^{144}$ PITKIN, Hanna Fenichel. El Concepto de Representacion. Op. Cit., pp. 177-178. 
definirem em uma plataforma online ${ }^{145}$. Trata-se, em verdade, de um mandato imperativo privado, dentro de um sistema público eleitoral regido pelo sistema representativo. Questão interessante ocorrerá se, eleito um parlamentar filiado a tal partido, passar a não observar as determinações da plataforma digital. Poderia o partido pedir a cassação do mandato parlamentar com base na previsão de seus estatutos? É possível que se reconhecesse que a previsão seria considerada ilegal ou inconstitucional, já que o partido político não poderia alterar a natureza da representação política prevista no sistema eleitoral vigente ${ }^{146}$.

O sentimento contrário à política tradicional ganhou forte adesão na Itália com o Movimento 5 Estrelas (MoVimento 5 Stelle ou M5S), um partido político que busca se identificar exatamente como um não partido ${ }^{147}$. Parte da concepção de que a democracia deve ser direta e a vontade política manifestada pela internet. Os candidatos não são políticos tradicionais. Como a Constituição Italiana também garante a independência do representante, o Movimento pretendeu submeter pré-candidatos do partido a assinarem um compromisso de pagamento de multa de 150.000 euros, caso não adotassem o programa do partido uma vez eleitos ou não renunciassem em caso de condenação criminal ${ }^{148}$. Não se pretende aqui discutir a validade jurídica de tal compromisso, mas sim o crescimento do interesse social em realizar o controle do mandato.

No Brasil o aplicativo para telefonia celular Mudamos+ foi criado visando aproximar a população do exercício direto do poder político, viabilizando, em plataforma digital, a adesão a projetos de lei de iniciativa popular ${ }^{149}$.

Outra figura que pretende desafiar as formas tradicionais de representação política é o "mandato coletivo". Consiste na candidatura em que, embora seja realizada formalmente e de acordo com as normas eleitorais vigentes, a inscrição de apenas um candidato, devidamente filiado a partido político, na prática, o exercício se dará por uma coletividade de indivíduos que previamente se apresentaram coletivamente. As manifestações no parlamento serão fruto de um consenso, ou por maioria, entre os integrantes do "mandato coletivo", embora a manifestação formal seja realizada apenas por quem regularmente

${ }^{145} \mathrm{O}$ partido ainda não elegeu representantes de modo que não há elementos empíricos acerca de como se exigiria do parlamentar a observância do quanto decidido pela população via plataforma digital.

${ }_{146}$ É possivel, contudo, que eventual demanda indenizatória promovida pelo partido, em face do representante eleito lograsse êxito.

${ }^{147}$ Fundado em 2009 pelo comediante Beppe Grillo.

148 "Raggi: nel contratto multa da 150 mila euro e clausola dimissioni”. Corriere Della Sera. Disponível em: <https://www.corriere.it/politica/16_settembre_11/raggi-contratto-multa-150-mila-euroclausola-dimissioni-209277f4-779a-11e6-a5b1-4fe0f4da1c53.shtml?refresh_ce-cp >. Acesso em 22/10/2018.

${ }^{149}$ Disponível em: <https://www.mudamos.org/quem-somos>. Acesso em 05/04/2018. 
integrou o processo eleitoral e veio a ser diplomado. No Brasil, nas eleições de 2018, logram sucesso duas candidaturas coletivas" ${ }^{\prime 150}$.

Estes instrumentos permitem que se questione se a forma de representação política atual tutela efetivamente as aspirações da sociedade, que por sua vez, se vê limitada à formação daqueles que exercerão poder nos órgãos legislativos, executivos e judicial em alguns sistemas.

\subsection{Instrumentos de participação direta.}

Nos regimes democráticos, as instituições cumprem dois papéis essenciais, a distribuição do poder de tomada de decisões e de garantir a participação dos cidadãos no julgamento político quanto ao conteúdo de tomada de decisões. Esse segundo aspecto representa a possibilidade de os cidadãos transformarem seus interesses e anseios em políticas públicas ${ }^{151}$.

A democracia qualificada como "participativa", "expansiva" ou "deliberativa" pode ser entendida como gênero do qual os mecanismos de democracia direta são espécies. Além dos instrumentos de participação direta institucionais como plebiscito, referendo, iniciativa popular de lei, recall, e outros, a democracia participativa engloba todo tipo de maior envolvimento no qual o cidadão tome parte em relação a decisões públicas, como manifestações populares, por exemplo. Nelas ocorre uma maior inserção do cidadão na esfera política, que não necessariamente terá caráter deliberativo, podendo ou não ter natureza meramente consultiva, como nos sistemas de orçamento participativo, a depender do conteúdo da lei que o preveja. A democracia participativa representa mais um inflexão nas decisões do que sua realização propriamente dita.

O artigo 23.1 da Constituição Espanhola de 1978 aponta ser direito dos cidadãos participar dos assuntos públicos, diretamente ou por meio de representantes, eleitos

${ }^{150} \mathrm{Na}$ Assembleia Legislativa do Estado de São Paulo foi eleita a deputada Monica Seixas, pelo PSOL, juntamente com outros sete "co-candidatos", e que se denominavam integrantes da Bancada Ativista. Na Assembleia Legislativa de Pernambuco a candidata Jô Cavancalti, também do PSOL, que integrava o movimento Juntas, foi eleita. Ela se apresentava como "co-candidata", junto com outras quatro mulheres. $\begin{array}{llllll}\text { Disponível em: } \quad<\text { https://bancadaativista.org/>.. Acesso em } & \text { 16/05/2019 e }\end{array}$ <https://www.juntascodeputadas.com.br>. Acesso em 16/05/2019.

151 MOISÉS, José Alvaro. "Democracia e Desconfiança das Instituições Democráticas". In: MOISÉS, José Alvaro. (org.) Democracia e Confiança - Por que os Cidadãos Desconfiam das Instituições Públicas? São Paulo: Editora Universidade de São Paulo, 2010, p. 47. 
livremente por meio de sufrágio universal ${ }^{152}$. A Constituição Brasileira de 1988, de seu turno, no artigo $1^{\circ}$, parágrafo único, aponta que todo o poder emana do povo, que o exercerá diretamente ou por meio de representantes eleitos, nos termos da carta constitucional.

A defesa da democracia participativa parte de uma crítica à democracia representativa, um desejo de realização do ideal democrático do ponto de vista da igualdade política na tomada de decisões e a aspiração de autorrealização com indivíduos plenos em uma sociedade harmônica.

Mercê da insuficiência do sistema democrático representativo, no qual a principal função dos cidadãos é eleger seus governantes, ao longo do tempo foram criados instrumentos nos quais o povo, diretamente e sem intermediários, exerce o poder político. Estes instrumentos conferem também maior legitimidade às decisões políticas. Por exemplo, algumas questões sensíveis, como porte de armas e legalização do aborto, quando tomadas por meio de instrumentos de participação direta, fornecem uma maior aceitação social sobre o resultado.

Não se pode ignorar que toda decisão política que emane diretamente dos cidadãos, mediante manifestação individual, corresponde, de forma mais próxima, palpável e imediata, à soberania popular ${ }^{153}$. Porém, o aparente afastamento do ideal democrático em razão da representação política não impede que existam instrumentos que tornem mais permeável o ingresso da manifestação popular junto às decisões políticas.

Kelsen, porém, adverte que um dos inimigos da democracia consiste em fazer o povo acreditar que a democracia é muito formalista e que o importante é que o interesse do povo seja atingido, o que dispensaria sua participação no governo ${ }^{154}$. De outro lado, o excesso de democracia, para Bobbio, pode representar o seu principal algoz, mesmo a pretexto de incrementá-lo, podendo produzir um efeito de saciedade da esfera política e, consequentemente, o aumento da apatia eleitoral ${ }^{155}$.

Na mesma linha Agesta asseverava que em relação a questões técnicas o povo não deveria se manifestar, seja porque o tema não lhe interessa, seja porque reconhece a sua própria incompetência. Assim, a opinião como consensus refletiria apenas os princípios

152 “23.1 1. Los ciudadanos tiene el derecho a participar en los asuntos públicos, diretamente o por medio de representantes, libremente elegidos en elecciones periódicas por sufragio universal". Disponível em: http://www.congreso.es/docu/constituciones/1978/1978_cd.pdf. Acesso em 05/02/2019. LiberArs, 2018, p.75.

${ }^{154}$ KELSEN, Hans. A Democracia. Op. Cit., p. 145.

${ }^{155}$ BOBBIO, Norberto. O Futuro da Democracia. Op. Cit., p. 39. 
básicos de uma comunidade política, já que as diversas correntes de opinião se referem normalmente às decisões dos problemas políticos eventuais e tendem a orientar o debate e os resultados eleitorais ${ }^{156}$.

Muitas são as críticas que sofrem os mecanismos de exerícicio direto da democracia. Em primeiro lugar, ela poderia enfraquecer a autoridade dos governos e parlamentares eleitos, diminuindo sua reponsabilidade ${ }^{157}$. Um segundo argumento refere-se à alegação de que os cidadãos não têm capacidade para decidir, e poderiam ser enganados e manipulados por demagogos. Uma terceira via de oposição sustenta que as decisões políticas institucionais são fruto de debates, confrontos, negociação, e a decisão final, ao menos em tese, apresenta moderação. Isso não ocorre nos mecanismos de democracia direta, em que não há possibilidade de negociação quanto ao conteúdo da decisão, havendo mera adesão ou rejeição à consulta ou ao projeto de lei de iniciativa popular, por exemplo, o que comprometeria também a qualidade técnica da norma. Uma quarta crítica aos mecanismos de democracia direta é representado pela chamada tirania da maioria em opressão à minoria, ou seja, direitos de minorias que foram sedimentados a custa de negociação com órgãos representativos poderiam ser suprimidos por meio de consultas populares. Ainda, caberia apontar que a influência do poder econômico comprometeria a lisura dos chamamentos populares ${ }^{158}$ e que os instrumentos de participação direta podem ser utilizados para legitimar regimes autoritários, na medida em que o governante, sustentando a necessidade de dispor de maior autonomia e poder, submete ao eleitorado a confirmação da ampliação de seu espectro de poder, como indispensável à sua $\operatorname{administração~}^{159}$.

$\mathrm{Na}$ mesma linha de raciocício, não necessariamente uma política aceita pela maioria dos cidadãos pode ser boa para o interesse comum. A título de exemplo, em relação à reforma da previdência, imagine-se que a população fosse questionada se deveria ser p. 243.

${ }^{156}$ AGESTA, Luis Sanchez. Princípios de Teoría Política. 3. E.d. Madrid: Editora Nacional, 1970,

157 Alessandro Soares arrola três situações em que haveria enfraquecimentos da representação legislativa: (a) o Poder Legislativo se vale de uma consulta popular para se livrar da responsabilidade de decidir; (b) O Executivo, sem maioria legislativa para governar, aciona mecanismo de participação direta para contornar eventual resistência junto ao parlamento; (c) os cidadãos apresentam iniciativa para uma consulta popular, ultrapassando os órgãos de representação. SOARES, Alessandro. A Democracia Direta no Constitucionalismo Latino-Americano e Europeu: análise comparada de Venezuela, Equador. Brasil e Espanha. São Paulo: LiberArs, 2017, p. 98.

${ }^{158}$ Idem, Ibidem, pp. 97-112.

${ }^{159}$ Tal fenômeno pode ser identificado na Turquia, em que o presidente Recep T. Erdogan, em abril de 2017, conseguiu aprovar a transformação de um regime parlamentar em presidencialista, expandindo seus poderes diante da extinção do cargo de primeiro-ministro, conforme tratado no capítulo anterior. 
postergada a idade de aposentadoria de todos os contribuintes. Seria natural que um referendo fosse rejeitado a vista dos interesses individuais envolvidos pelos cidadãos votantes. Além disso, em muitos casos, pouco importaria a efetiva informação, mas sim o conceito anterior existente em relação ao objeto da votação.

Sartori afirma não ser possível em uma democracia a maximização do poder popular e, ao mesmo tempo, mais planejamento elaborado por uma razão científica especializada, identificando-se uma verdadeira antítese entre a democaria direta e a tecnocracia $^{160}$.

Christopher Achen e Larry Bartels realizaram extensa avaliação dos mecanismos de participação direta, como o plebiscito e o referendo, nos Estados Unidos. As dificuldades, segundo os autores, remontam ao fato de que os votantes ficam confusos com as informações apresentadas e os instrumentos são caros e ineficientes. Citam eles alguns exemplos em que a consulta popular tem resultados questionáveis. Em um deles, visando não elevar impostos, populações de várias cidades norte-americanas votaram negativamente à proposta de fluoretação da água entre 1950 e 1960. Embora tenha sido realizada uma economia anual em valor ínfimo, aumentou exponencialmente o número de visitas de cidadãos ao dentista, com gastos substanciais. Outro caso se refere à imunização de crianças. Quando em algumas cidades a população optou por não obrigar a vacinação, epidemias de doenças que há muito estavam erradicadas voltaram a aparecer ${ }^{161}$. Por fim, no início dos anos 90, cidades do estado de Illinois, realizaram consulta popular sobre aumento das taxas acima da inflação, sendo rejeitado em muitas delas. $\mathrm{O}$ estudo realizado demonstrou que o aumento para uma casa tipo implicaria em majoração de 43 centavos anuais. Nas cidades em que foi rejeitado o aumento, observou-se piora no serviço de bombeiros, com atraso de mais de um minuto no tempo médio de chegada gerando incremento no custo de seguros residenciais, ou seja, a economia no imposto implicou em piora do serviço e mais custos financeiros ${ }^{162}$. Por isso, em relação ao referendo argumentam que o instrumento deveria ser relegado para questões que envolvam princípios gerais, e não para questões onde uma opinião racional apenas pode ser formada

${ }^{160}$ SARTORI, Giovanni. A Teoria da Democracia Revisitada. Vol. 2. São Paulo: Ática, 1994, p. 229.

${ }^{161}$ ACHEN, Christopher. H. e BARTELS, Larry M. Democracy for realists Why Elections Do not Produce Responsive Government. Princeton: Princeton University Press, 2016, p. 54.

${ }^{162}$ Idem, Ibidem, p. 83. 
com o conhecimento de detalhes que não seriam viáveis aos cidadãos ordinários. ${ }^{163}$. Cabe aqui a reflexão sobre a advertência de Bobbio, para que o referendo é um instrumento extraordinário a ser utilizado em situações extraordinárias ${ }^{164}$.

Malgrado fundadas, as críticas merecem algumas ponderações. Os mecanismos de democracia direta não serviriam para enfraquecer os representantes constituídos, ao contrário, serviriam como canal de maior comunicação entre eles, reforçando o vínculo e a responsabilidade entre representantes e representados. O elitista argumento de incapacidade dos cidadãos não se sustenta, a nosso ver. Em primeiro lugar, porque não se lança mão de tal argumento para dizer que os cidadãos também poderiam ser manipulados nas eleições para escolher representantes ruins, o que justificaria até o abandono da democracia para a escolha de representantes mais aptos. Além disso, na democracia contemporânea não se tem exigido dos representantes que demonstrem conhecimento técnico ou pessoal para que se tornem candidatos. Logo, não haveria que ser exigido profundo conhecimento técnico dos cidadãos para que pudessem se manifestar politicamente. Sobre a falta de debate nas decisões populares, a assertiva é parcialmente verdadeira. Embora a manifestação final do cidadão corresponda à adesão ou rejeição de uma consulta, isso não quer dizer que previamente não houve debate em determinados grupos sociais, audiências públicas, manifestação de profissionais, etc. Essa clivagem também implica em um filtro normativo capaz de aprimorar a qualidade destas peças, como projetos de iniciativa popular de lei, sendo certo, por fim, em caso de deficiências normativas mais profundas, caberá ao Poder Judiciário analisar a aplicabilidade da norma. O abuso do poder econômico igualmente é questão relevante nos pleitos eleitorais, de modo que não pode ser invocado como um problema atinente aos instrumentos de democracia direta. Por fim, acerca do risco de ditadura da maioria suprimindo direitos das minorias é certo que a maioria pode ser fixada não apenas com base na grandeza aritmética simples, mas exigindo-se, por exemplo, quóruns mais elevados para a supressão de direitos, exigência de maioria absoluta para aprovação, número mínimo de entes federados em que exista a vitória de determinada decisão, etc. Além disso, é certo que as constituições têm também a função de salvaguardarem em suas cláusulas pétreas os direitos que não poderão ser objeto de alteração ou supressão, seja por meio do exercício

${ }^{163}$ Os autores apresentam pesquisas que mostram que mais de $1 / 3$ da população não vai votar na maior parte dos referendos e muitas das medidas adotadas sequer obtinham mais da metade dos que se apresentaram para votação, de modo que raramente o referendo poderia ser identificado como um instrumento que fornece uma opinião pública genuína. Idem, Ibidem, pp. 69-70.

${ }^{164}$ BOBBIO, Norberto. O Futuro da Democracia. Op. Cit., p. 66. 
do poder reformador derivado ou pelo exercício dos instrumentos de democracia direta. Por fim, sobre o risco de decisões que não atendam necessariamente ao interesse público, conforme já abordamos anteriormente, a identificação do objeto do que seria "melhor" para um determinado grupo, constitui questão de dissenso também para o próprio parlamento e para os gestores públicos.

Alessandro Soares classifica os mecanismos de exercício de democracia direta em: (a) modalidades de consulta submetidas à manifestação popular direta e imediata que tratem de criação, alteração ou revogação normativa, aqui incluídas as consultas populares como referendo, plesbicito; (b) formas de iniciativa fundadas no exercício de competências constitucionais por meio do direito de petição de fração do eleitorado, incluídas nesta modalidade, iniciativa popular de lei, revogação de mandato político, antecipação de eleições, convocação de assembleia constituinte, etc ${ }^{165}$.

Os dois instrumentos democráticos, a representação e o exercício direto, não são excludentes, mas complementares. Como instrumentos de participação direta podem ser mencionados o plebiscito, o referendo, a iniciativa popular de lei, o veto popular, o referendo constitucional e a revogação de mandato, comumente conhecida como recall.

No plebiscito a população é chamada para deliberar de forma prévia sobre uma determinada questão enquanto no referendo a manifestação ocorre a posteriori, apenas confirmando o que já foi deliberado. A convocação de ambos, no Brasil, cabe ao Congresso Nacional, nos termos do artigo 49, XV, Constituição Federal. Na iniciativa popular de lei consiste na apresentação de projeto de lei subscrito por determinada parcela do eleitorado de modo a obrigar que o parlamento, na respectiva esfera de poder, tenha que discutir a questão trazida.

A Colômbia realizou uma interessante consulta popular plebiscitária vinculada à corrupção e uma minirreforma política. A população decidiu, entre outras questões, sobre a redução de salários de congressistas, possibilidade de prisão para corruptos, necessidade de prestação de contas anuais, realização de audiências públicas. Interessante observar que em todas as questões, a resposta foi positiva em percentual superior a 99\%. Todavia, as

165 SOARES, Alessandro. A Democracia Direta no Constitucionalismo Latino-Americano $e$ Europeu: análise comparada de Venezuela, Equador. Brasil e Espanha. Op. Cit., p. 74. 
medidas não foram implementadas a vista do não atingimento do número mínimo de $\operatorname{votantes}^{166}$.

$\mathrm{O}$ veto popular e o recall não são adotados pelo Brasil. O veto consiste na possibilidade de o eleitorado, mediante voto direto, afastar do ordenamento jurídico uma norma vigente aprovada pelo parlamento. A revogação de mandato (recall), por fim, representa a possibilidade de determinada fração do eleitorado propor que um ou vários mandatos eletivos sejam submetidos a escrutínio popular, antes do término do prazo legal $^{167}$.

A esta altura cabe a seguinte indagação. Se o objeto deste trabalho são as propostas eleitorais, por que a preocupação com os mecanismos de democracia direta?

Como poderemos verificar no capítulo seguinte, em que trataremos das Proposições Eleitorais, nossa reflexão inclina-se para que as propostas deixem de representar um nada jurídico absoluto e constituam efetivamente um instrumento de democracia participativa, tanto trazendo maior transparência ao cumprimento das propostas, como trazendo consequências, ao seu descumprimento. Os instrumentos de participação direta atualmente existentes, como referendo e plebiscito, são custosos. Por isso, a tutela jurídica das propostas de campanha poderia prevenir inclusive uma nova chamada às urnas.

\subsection{Confiança política e mecanismos de controle da representação.}

Antes de tratar o tema da confiança política é imperioso realizar uma breve distinção entre Governo e Administração Pública.

A Administração Pública, no dizer de Bucci, corresponde ao conjunto de atividades destinadas à execução concreta das tarefas ou incumbências consideradas de interesse público ou comum, em um determinado agrupamento. De outro lado, Governo, em ciência política, refere-se ao conjunto de pessoas que exercem poder político e que determinam os destinos políticos de um determinado grupo social. Nota-se que no conceito de 
Administração Pública se exclui parte da atividade dos órgãos de tipo político, como atividades de cunho internacional ou convocações para eleições e referendos ${ }^{168}$.

O Governo representa um organismo complexo formado por órgãos colegiados, como Ministérios e Conselhos e por órgãos singulares, Chefe do Poder Executivo e seu vice, Ministros e Secretários. Os governos tem por missão institucional organizar a alocação dos meios públicos, dirigir e executar a Administração Pública e, principalmente, promover a coordenação, o planejamento e a execução das ações coletivas em diferentes níveis. A atividade governamental deve buscar determinado equilíbrio temporal, para que o planejamento estratégico seja longo o bastante para cumprir a execução do objetivo, mas sem que se perca a credibilidade por não se identificar a proximidade do resultado ${ }^{169}$. Políticas públicas relacionadas à educação, por exemplo, muitas vezes sofrem com a pressa dos gestores em apresentarem resultados que politicamente poderiam lhe ser favoráveis.

A relação de confiança existe quando alguém entrega a outro uma responsabilidade pelo exercício de determinada atribuição que, segundo Comparato, no caso do mandato político reside, na responsabilidade pelo desempenho de um cargo ou função pública ${ }^{170}$. Em que consiste, então, a confiança no aspecto eleitoral? A confiança consiste em acreditar que determinadas pessoas realizarão um comportamento específico, positivo ou negativo, que representa uma ação ou omissão, capaz de incrementar uma situação de bem-estar ou, ao menos, deixar de impor maiores prejuízos a quem depositou a confiança. A confiança pode ter por objeto tanto pessoas como instituições ${ }^{171}$.

A falta de confiança na democracia conduz a uma ampliação do descompromisso com a vida pública, com a concepção de bem comum, afastando-se do cumprimento de normas e leis, na medida em que fruto de governos e partidos políticos que não gozam de respeitabilidade popular $^{172}$.

Tratando do cargo presidencial, Gargarella afirma que em tempos de prosperidade, apenas o presidente recebe prestígio, poder e capacidade de ação, enquanto em tempos de crise, o período ruim não é atribuído apenas ao governante, desbordando para a própria estrutura institucional, já que a falta de um "fusível" que autorize o reparo, ameaça

168 BUCCI, Maria Paula Dallari. Fundamentos para uma Teoria Jurídica das Políticas Públicas. São Paulo: Saraiva, 2013, pp. 54 e 58-59.

${ }^{169}$ Idem, Ibidem, p. 33.

${ }^{170}$ COMPARATO, F. K. Rumo à Justiça. São Paulo: Saraiva, 2. Ed., 2013, p. 437.

${ }^{171}$ MOISÉS, José Alvaro. "A Confiança e os seus Efeitos sobre as Instituições Democráticas”. In: MOISÉS, José Alvaro. (org.) Democracia e Confiança - Por que os Cidadãos Desconfiam das Instituições Públicas? São Paulo: Editora Universidade de São Paulo, 2010, p. 9.

${ }^{172}$ Idem, Ibidem, p. 12. 
“incendiar", não apenas o presidente, mas o sistema institucional leia-se a confiança democrática $^{173}$. O mau governo, portanto, coloca em risco, ainda que paulatinamente, o próprio sistema democrático. Com esse pensamento se alinha Moisés, que adverte que uma situação de desconfiança perene, generalizada e crescente na democracia, ainda que não conduza a sua destruição no curto prazo, indica que os cidadãos não acreditam que as instituições públicas postas são capazes de implementar aquilo que eles esperam do regime $^{174}$.

A confiança opera como fator estabilizante, sobretudo nas novas democracias, pois fortalece a aceitação e submissão ao estado de direito, ou seja, à observância das leis, por parte da população, que naturalmente disputa a realização dos interesses pessoais. A confiança, sob o aspecto social, se relaciona com a segurança que a população deposita nas instituições como elemento de cooperação e coordenação para resolver suas preocupações decorrentes da vida social e política do mundo globalizado ${ }^{175}$.

A crise de representação política assenta-se no rompimento do vínculo subjetivo entre o que os cidadãos eleitores pensam e querem e as efetivas ações daqueles que são eleitos, criando-se o majoritário sentimento de que os políticos eleitos pelo sistema vigente não os representa ${ }^{176}$. Tal pode ser observado em manifestações populares na Espanha, em maio $2011^{177}$, e no Brasil, em junho de $2013^{178}$.

${ }^{173}$ GARGARELLA, Roberto. El derecho a la protesta: El primer derecho. Buenos Aires: Ad-Hoc, p. 133 .

${ }^{174}$ MOISÉS, José Alvaro. A Confiança e os seus Efeitos sobre as Instituições Democráticas. Op. Cit., p.12.

${ }^{175}$ Idem, Ibidem, p. 48.

176 "Mais de dois terços dos habitantes do planeta acham que os políticos não os representam, que os partidos (todos) priorizam os próprios interesses, que os parlamentos não são representativos e que os governos são corruptos, injustos, burocráticos e opressivos”. E continua Manuel Castells tratando dos índices de confiança política na Espanha: "Se, em 2000, 65\% dos cidadãos não confiavam nos partidos políticos, a desconfiança subiu para 88\% em 2016. Em relação ao Parlamento, aumentou de 39\% em 2001, para 77\% em 2016, enquanto que, em relação ao governo, passou de 39\% para 77\% no mesmo período" CASTELLS, Manuel. Ruptura: a crise da democracia liberal (Trad. Joana Angélica d'Ávila Melo). Rio de Janeiro: Zahar, 2018, pp. 12 a 15. Gráficos disponíveis em anexo virtual: <https://zahar.com.br/sites/default/files/arquivos/material_de_apoio_-_dados_de_base.pdf>. Acesso em $16 / 04 / 2019$.

177 Na Espanha o movimento ficou conhecido como 15-M ou "indignados", clamando por “Democracia Real Ya!”, congregando reinvindicações de todas as ordens, tendo como fio condutor a rejeição ao sistema político representativo e a política institucional em relação aos cidadãos. CASTELLS, Manuel. Ruptura: a crise da democracia liberal. Trad. Joana Angélica d’Ávila Melo. 1. ed. Rio de Janeiro: Zahar, 2018, pp. 99/100.

${ }^{178}$ No Brasil os protestos iniciaram-se contra um aumento de 20 centavos no valor das tarifas de transportes públicos, passando posteriormente a congregar uma gama de diferentes bandeiras que se insurgiam contra a corrupção, a má qualidade dos serviços públicos, a violência e, especialmente, a representação política, de modo que umas das características das manifestações era a rejeição à presença de representantes de partidos políticos. 
Quem recebe poder deve responder por ele. Deve também receber os meios necessários, os poderes para a execução dos deveres. Agesta define a responsabilidade política como a sujeição dos membros do governo a um órgão que discuta se os atos por eles praticados se dirigiram aos fins propostos, realizando uma análise sobre a conveniência e oportunidade das medidas. A responsabilidade política está vinculada à atividade de controle, podendo ser exercida pela oposição legítima e por outros órgãos constitucionais $^{179}$

Francisco de Vitoria lembra, sob os auspícios da monarquia, que se o rei governa de forma tirânica, a república pode depô-lo. Embora ele tenha autoridade outorgada pela própria república, permanece com ela o direito natural de defender-se ${ }^{180}$.

Na Grécia Antiga os cidadãos considerados perigosos eram condenados por assembléia popular ao exílio político enquanto na Roma Antiga aqueles que eram acusados de delitos graves eram julgados pelo povo, em praça pública ${ }^{181}$.

A representação é objeto de controles de naturezas distintas. A representação política no pólo do Poder Executivo sofre controles político, judicial, político-jurídico e popular.

A interrupção do mandato é uma medida bastante grave em um regime democrático e não pode ser tomada como algo simples. Trata-se de, em última análise, tornar sem efeito o sufrágio manifestado nas eleições, razão pela qual deve ser reservado a questões relevantes, sobretudo porque o procedimento de remoção do governante - e também dos parlamentares, ainda que em grau menor - tem potencial para gerar insegurança e desestabilização política. Entretanto, reservado aos casos mais graves e com observância do devido processo legal, configura importante instrumento de responsabilização à restauração da confiança democrática.

Quando um governante é candidato à reeleição e não obtém êxito no processo de sufrágio, identifica-se possibilidade de responsabilização de ordem exclusivamente política, cuja punição adveio das urnas, em exercío da accountability vertical ${ }^{182}$. Embora não seja objeto de nossa pesquisa, que se limita ao estudo do Poder Executivo em regimes

${ }^{179}$ AGESTA, Luis Sanchez. Princípios de Teoría Política. Madrid: Editora Nacional, 3. E.d., 1970, p.409.

180 VITORIA, Francisco de. Relectio de Postestate Civili. Estudios sobre su Filosofía Política (Edición crítica por Jesús Cordero Pando). Corpus Hispanorum de Pace Segunda Serie. Madrid: Consejo Superior de Investigaciones Científicas, 2008, vol. 15, p. 139.

${ }^{181}$ MAXIMILIANO, Carlos. Comentários à Constituição Brasileira. $5^{\circ}$ ed. (atualizada). V. II. Rio de Janeiro: Freitas Barros, 1954, p. 105.

${ }^{182}$ KELSEN, Hans. Teoria Geral do Direito e do Estado. Op. Cit., p. 416. 
presidencialistas, no caso de regimes parlamentaristas, em que existe a cisão entre as figuras do Chefe de Estado e Chefe de Governo, verificada a baixa popularidade ou má administração do Primeiro Ministro, o Parlamento se manifesta por meio de moção de desconfiança, implicando na remoção automática do Primeiro Ministro, o que configura hipótese de responsabilização política, que não demanda a apresentação de maiores justificativas por parte dos parlamentares que promoveram a derrubada institucional do governo.

A responsabilização judicial ocorre nos casos em que o Chefe do Poder Executivo é afastado do governo em razão de uma decisão judicial, após o devido processo legal. A condenação pode ocorrer em um processo eleitoral, como ação de investigação judicial eleitoral ou recurso contra a expedição de diploma, bem como pela prática de crime comum $^{183}$ ou por ato de improbidade administrativa ${ }^{184}$.

Nos regimes presidencialistas o Chefe do Poder Executivo corporifica o líder da nação, aquele que representa os valores comuns da sociedade, de modo a identificar um poderoso exemplo para toda a população ${ }^{185}$. O instituto do impeachment constitui um procedimento de natureza político-jurídica pelo qual podem ser questionadas condutas do Chefe do Poder Executivo, culminando com seu afastamento. No dizer de Pérez-Liñán o impeachment transforma a sorte do político mais bem sucedido no país em modelo de fracasso, em que o presidente é destituído das honras e do poder que exercia, abandonado por aliados e eleitores, processado como cidadão comum e muitas vezes encarcerado ou obrigado a se exilar $^{186}$.

Seria impreciso dizer que se traduz em controle exclusivamente político, pois em muitos países como no Brasil, existe um verdadeiro processo e inclusive o controle quando não a presidência dos trabalhos - pela Corte Suprema. Da mesma forma não se pode tentar associar o processo de impeachment a um processo judicial, porquanto os juízes são os parlamentares, cuja vida institucional é voltada a práticas políticas, em tese, de forma distinta dos juízes de carreira. Chama à atenção o fato de que no Brasil, em menos de 30 anos de restauração democrática, dois Presidentes da República foram

\footnotetext{
${ }^{183}$ No Brasil, vide o artigo 92, I do Código Penal. A perda do mandato ocorrerá se a condenação for superior a 4 anos de prisão, em qualquer delito ou igual ou superior a um ano, quando o crime for praticado com absudo de poder ou violação de dever para com a Administração Pública.

${ }^{184}$ Nos termos do artigo 12 da Lei 8.429/1992.

185 POSNER, R. A. AN AFFAIR OF STATE - The Investigation, Impeachment and Trial of President Clinton. Cambridge, MA: Harvard University Press, 1999, Kindle Edition, posição 1828.

186 PÉREZ-LIÑÁN, Aníbal. Presidential Impeachment and the new political instability in Latin America. Cambridge, MA: Harvard University Press, 2007, Kindle Edition, p. 85. 
afastados pela via do impeachment, Fernando Collor de Melo, em 1992, e Dilma Vana Rousseff, em $2016^{187}$.

Os processos de impeachment são influenciados por uma série de fatores como popularidade do governante, sua força política pessoal e de seu partido, a percepção econômica vigente à época do processamento do pedido e o papel desempenhado pela imprensa. É exatamente a conjugação de tais elementos que tornará o impeachment mais ou menos plausível ${ }^{188}$.

Embora sob uma perspectiva o impeachment se mostre como destacado instrumento para o combate de ilegalidades cometidas pelo mandatário maior do Poder Executivo, não raro é utilizado para conferir uma roupagem jurídico-legal a um procedimento que, na realidade, objetiva a retirada de um governante que perdeu a habilidade de governar por não ter apoio no parlamento, conferindo uma falsa impressão de que o combate à ilegalidade era a razão única do procedimento ${ }^{189}$.

Nos sistemas presidencialistas, que tem por base a separação dos poderes e inexiste o instrumento da moção de desconfiança, não é lícito remover um governante simplesmente por ser ele impopular, fraco ou porque perdeu a base de apoio no Congresso Nacional, impossibilitando a aprovação de leis de seu interesse. Por essa razão, visando a estabilidade governamental, nos sistemas presidencialistas as regras para o processamento do impeachment costumam ser bastante rígidas, exigindo quórum elevado para as votações, normalmente envolvendo ambas as casas legislativas e em alguns países também uma Corte Superior. A austeridade tem por escopo - em tese e sem sucesso impedir que o procedimento seja utilizado de forma imoderada, por razões políticas,

187 A incidência do impeachment seria mais comum nas democracias mais jovens e frágeis, e o impedimento acabaria por constituir uma alternativa legal-constitucional mais desejável do que o colapso do sistema democrático por meio de um golpe militar ou até mesmo o assassinato do presidente. BAUMGARTNER, J.; KADA, N. CHECKING EXECUTIVE POWER - Presidential Impeachment in Comparative Perspective. Westport, CT: Praeger Publishers, 2003, p. 73.

${ }^{188}$ Alguns estudos pretendem identificar quais circunstâncias podem tornar mais ou menos provável a incidência e o sucesso de processos de impeachment. Jody Baumgartner e Naoko Kada arrolam cinco fatores que influenciam em um processo de impeachment: (1) o equilíbrio institucional de poder entre as várias esferas de governo; (2) a rigidez das regras constitucionais e legais que tratam do procedimento e conteúdo do impeachment; (3) a estrutura dos partidos políticos; (4) a popularidade do presidente anteriormente às alegações de desvio de conduta; (5) outros fatores como ambiente da mídia, condições econômicas e pressões internacionais. BAUMGARTNER, Jody; KADA, Naoko. CHECKING EXECUTIVE POWER - Presidential Impeachment in Comparative Perspective. Op. Cit., p. 133.

189 LEITE, Glauco Costa. "O Processo de Impeachment como Instrumento de Combate à Corrupção". In: Alexandre Jorge Carneiro da Cunha Filho; Glaucio Roberto Brites de Araujo; Roberto Livianu; Ulisses Augusto Pascolati Junior. (Org.). 48 Visões sobre a corrupção. São Paulo: Quartier Latin, 2016 , p. 460. 
atendendo aos interesses dominantes do parlamento que diante de mera insatisfação com o Chefe do Poder Executivo, pretendam substitui-lo.

Posner ensina que os debates envolvendo o impeachment sempre se encontram entrecortados por fortes elementos ideológicos, mesmo no meio acadêmico, gerando debates acalorados e, muitas vezes, os entendimentos são fixados anteriormente à análise dos fatos, recusando-se qualquer tipo de razão àqueles que detêm argumentos em sentido contrário $^{190}$.

Por fim, a revogação de mandato (recall), como vimos, consiste na possibilidade de os próprios cidadãos, por meio do voto, promoverem a extinção de mandato eletivo, antes do término do prazo legal, e se traduz em controle popular ${ }^{191}$. O instituto é previsto em alguns países como Equador, Colômbia e Venezuela. O recall tem um nítido efeito de accountability, na medida em que o governante não se vê alforriado de vínculo com os cidadãos apenas no próximo pleito eleitoral. $\mathrm{O}$ instrumento permite e promove maior controle pelos cidadãos sobre os representantes. Trata-se de uma função censora cometidas aos eleitores, no dizer da Caggiano, que vincula os governantes ao corpo eleitoral e impõe que se obeserve com maior cuidado a opinião pública, diante de uma constante ameaça psicológica de destituição ${ }^{192}$.

A crítica ao instituto é que ele se presta a servir como uma espada de Dâmocles ao governante, impedindo-o de tomar medidas, por vezes impopulares, mas que seriam necessárias ao bem comum, sobretudo a médio ou longo prazo. Deste modo, o representante perderia a independência e tenderia a governar com horizonte de curso prazo, evitando medidas socialmente amargas em um primeiro momento, o que aproximaria o instituto do mandato imperativo. Além disso, a existência do instituto permite, em tese, a tentativa de sabotagem do governo pela oposição. A alegação de perda de independência, com razão em certa medida, nos parece ceder espaço a um ponto mais relevante, o controle do poder político. Sopesando-se a impossibilidade de controle e a possibilidade de controle, ainda que isso tendesse a limitar a atuação do governante, nos parece que a segunda hipótese é mais prudente. Em relação ao confronto político, a crítica poderia recair a qualquer instrumento de controle, seja ele judicial ou mesmo político como o

${ }^{190}$ POSNER, Richard. A. AN AFFAIR OF STATE - The Investigation, Impeachment and Trial of President Clinton. Op. Cit., p. 1455.

191 SOARES, Alessandro. A Democracia Direta no Constitucionalismo Latino-Americano e Europeu: análise comparada de Venezuela, Equador. Brasil e Espanha. Op. Cit., p. 93.

${ }^{192}$ CAGGIANO, Monica Herman Salem. Oposição na Política. São Paulo: Angelotti, 1995, p. 97. 86 
impeachment. Portanto, criticar o recall sob o argumento de que ele traz beligerância à arena política é o mesmo que critica qualquer instrumento de controle.

De outro lado, sustenta-se que o recall tem como prerrogativa exatamente fortalecer a natureza democrática da representação. Afinal, o representante foi escolhido com base em uma determinada plataforma de propostas com a qual o corpo eleitoral aderiu, de modo que a possibilidade de revogação do mandato, se certa maneira, previne, ou ao menos torna menos provável que ocorram os denominados estelionatos eleitorais, no qual o candidato se elege com uma clara e determinada plataforma de governo populista, mas a qual adrede sabe que não observará, de tal sorte que logo nos primeiros dias de governo, passa a governar em sentido contrário a suas propostas. Além disso, o recall poderia representar uma solução institucional mais rápida em comparação com a lentidão do procedimento de impeachment e todo o jogo de cena político acerca da suposta tipificação do crime de responsabilidade.

\subsection{Insuficiência dos mecanismos existentes.}

As bases que fundamentam as democracias liberais são: representação popular decorrente de eleições livres, separação dos poderes com controle do governo pelo parlamento, hierarquia das normas jurídicas com fundamento na legalidade. Estas instituições têm por objetivo limitar e regular o poder político, preservando-se a liberdade dos cidadãos ${ }^{193}$.

No sistema presidencialista boa parte das expectativas do eleitorado centra-se na figura do Chefe do Poder Executivo, que conta com mandato fixo e goza de maior estabilidade do que nos regimes parlamentaristas, ainda que considerados os sistemas que dispõem do mecanismo de controle por recall.

O problema a pontuar é que atualmente a responsabilização política, conforme tivemos a oportunidade de observar no item anterior, consiste em um "tudo ou nada", na medida em que ou Chefe do Poder Executivo é apeado do poder, seja pela via judicial, por meio de impeachment ou recall ou, permanece no cargo até o termo do mandato, sem qualque ônus, ainda que tenha se afastado flagrantemente do programa eleitoral de governo proposto.

193 DUVERGER, Maurice. Institutions Politiques et Droit Constitutionnel - Les grands système politiques. $12^{\circ}$ Ed. Tomo I. Paris: Presses Universitaires de France, 1971. t. 1, p. 98. 
Outra questão que poderia dar ensejo a maior responsabilização seria responsabilizar o partido político em razão do descumprimento de conduta por um de seus correligionários em exercício no poder, de modo que o partido político responderia objtetivamente pela conduta de seus integrantes, o que, em tese, tornaria mais rigorosos os critérios de aceitação para ingresso no partido ${ }^{194}$.

Retomando o nosso tema de estudo, pretendemos discutir duas questões relacionados às propostas eleitorais. Uma delas é a possibilidade de maior transparência em relação àquilo que foi proposto pelo candidato e o quê foi efetivamente implementado, com a incidência de consequências jurídicas legalmente previstas. A outra consiste em identificar possibilidades de responsabilização que se enquadrem de forma intermediária entre a deposição do cargo e a inexistência de qualquer consequência jurídica para o governante que se afasta de práticas voltadas aos compromissos eleitorais realizados. Tais medidas poderiam funcionar como reforço democrático do conteúdo do processo eleitoral de manifestação de propostas, bem como serem identificadas, em algumas hipóteses, com caráter contratualista, de modo a conferir direitos e obrigações ao governante, enquanto os cidadãos, coletivamente, titulariam direitos subjetivos que poderiam ser invocados em sede judicial.

Enquanto não houver uma norma que expressamente obrigue o governante a pautar-se pelo cumprimento das propostas, importando em consequências jurídicas relevantes, a obrigação seguirá conformada em caráter meramente moral, com consequências limitadas à accountability vertical no âmbito da esfera política.

\subsection{O Constitucionalismo Aspiracional e a democracia responsiva.}

O constitucionalismo aspiracional implica em identificar que os princípios, valores e direitos sociais contidos no texto constitucional não são meras formulações retóricas, mas normas que devem ter efeitos imediatos. Diante desta interpretação dois caminhos são possíveis segundo Villegas, a mobilização política e o controle judicial das leis e atos

${ }^{194}$ Esta é inclusive uma das críticas realizadas por Claudio Lembo em relação à Lei Ficha-Limpa, que segundo ele deveria ter ido além, responsabilizando objetivamente os partidos políticos por condutas de seus correligionários. Ele cita como exemplo o artigo 107 da Constituição da Colômbia de 1991, que fixa a responsabilização do partido político cujo integrante é condenado a crime relacionado ao narcotráfico. LEMBO, Cláudio. Faltou Algo Na Lei da Ficha Limpa. In: Monica Herman Caggiano. (Org.). Ficha Limpa Impacto nos tribunais: tensões e confrontos. 1. ed. São Paulo: Revista dos Tribunais, 2014, p. 119. 
administrativos, que não seriam vias complementares, mas podem ser excludentes ${ }^{195}$. Para o autor esse constitucionalismo voltado à concretização dos valores não tem se mostrado capaz de encontrar uma complementariedade entre a participação democrática e a proteção judicial de direitos, gerando um antagonismo que por vezes inclina-se a fenômenos caudilhistas e populista, com forte participação de maiorias, mas com baixa proteção de direitos e por outras uma elevação do ativismo judicial, em que há forte proteção de direitos, mas baixa participação política ${ }^{196}$.

Nesta linha, Nino aponta que a democracia deliberativa, representa a conexão da esfera política com a esfera moral, na medida em que a decisão política é atingida após um exercício de discussão coletiva racional e institucionalizado, que permite uma maior aceitação da decisão ${ }^{197}$. Este espectro não visa simplesmente proteger a manifestação das minorias para que não sejam oprimidas pela força da maioria, mas sim buscar a melhor decisão, que traga mais benefícios à sociedade como um todo, sem uma simples divisão entre maioria e minoria ${ }^{198}$.

Portanto, estes institutos nos levam à seguinte reflexão: é possível encontrar uma solução democrática para a concretização dos valores constitucionais que privilegie o consenso, sem desbordar para a ascensão unilateral quer da esfera judicial quer da esfera política, na qual uma se sobreponha sobre a outra?

A análise do fenômeno positivista do direito por vezes leva o jurista a encontrar dificuldades ao tentar realizar o encontro do direito e da política, por meio de construção de normas e arranjos institucionais ${ }^{199}$.

A responsividade de um governo corresponde a uma resposta, um comportamento de exigência e cumprimento. Por isso, para alguns, a responsividade compõe de forma antecedente o conceito responsabilidade, que é a exigência a uma resposta pela conduta

195 VILLEGAS, Mauricio Garcia. Constitucionalismo Aspiracional: Derecho, Democracia y Cambio Social en América Latina. Revista Análisis Politico. Bogota, v. 25, ed. 75, p. 93, maio-agosto, 2012.

${ }^{196}$ Idem, Ibidem, p. 102.

197 NINO, Carlos Santiago. La constitución de la democracia deliberativa. Barcelona: Gedisa Editorial, 1997, p. 198.

198 Privilegiam-se, assim, os parlamentos, de modo que embora tenha valor, o Chefe do Poder Executivo não se situaria no núcleo do governo democrático. LISOWSKI, Telma Rocha. Mandato Parlamentar \& Crise de Representatividade: instrumentos de perda e reforma do sistema. Curitiba: Juruá, 2018, p. 51-52.

199 BUCCI, Maria Paula Dallari. Fundamentos para uma Teoria Jurídica das Políticas Públicas. São Paulo: Saraiva, 2013, p. 245. 
que não foi cumprida ${ }^{200}$. Enquanto a responsividade representa o dever de cumprimento (compliance), a responsabilidade atua para apurar eventual descumprimento.

Uma democracia qualificada pelo instituto da responsivenss corresponde a um regime democrático em que se busca a correspondência entre as ações de governo e os anseios dos governados ${ }^{201}$. Portanto, a responsividade - a que emprestaremos significado como sinônimo para responsiveness, sem maiores questionamentos etiológicos corresponde a um atributo que indica um nível mais elevado de democracia.

A democratic responsiveness ou uma democracia responsiva tem como pressuposto a a existência de uma "democracia eleitoral" 202 . Isso implica dizer que na democracia procedimental eleitoral importa a lisura e a igualdade no procedimento de escolha dos governantes, ao passo que naquela, após a eleição observa-se em que medida os anseios populares são considerados quando da adoção das medidas adotadas pelo governo. E mais do que isso, se existem canais que permitem tal manifestação gerando permeabilidade do governo às manifestações que tem origem na cidadania.

Trasladado o conceito para as propostas eleitorais, um comportamento responsivo corresponderá à conduta do titular eleito ao cargo de chefia do Poder Executivo que direciona sua conduta administrativa para o cumprimento das propostas realizadas em campanha. A responsividade não se limitará, porém, às propostas, pois o governante deverá continuar orientando sua atuação por meio do interesse dos governados. Para tanto, Leonardo Morlino propõe a realização de surveys, pesquisas de opinião, a serem submetidas à cidadania. Morlino se mostra ciente das limitações das pesquisas, mercê da necessidade de conhecimentos específicos em muitas oportunidades para avaliar uma política pública, o que, porém, não invalida ou dispensa a importância de interlocução entre governantes e governados. Por isso, aponta o autor a legitimidade do governo como um dos principais pilares de análise da responsividade, caracterizada por elementos de conduta pública que confirmam ou infirmam a satisfação com o governo ${ }^{203}$.

\footnotetext{
${ }^{200}$ LISOWSKI, Telma Rocha. Mandato Parlamentar \& Crise de Representatividade: instrumentos de perda e reforma do sistema. Curitiba: Juruá, 2018, p. 76.

${ }^{201} \mathrm{O}$ termo responsiveness não possui tradução literal na língua portuguesa, estando o termo já incorporado internacionalmente pela ciência política. LORENCINI, Bruno. Democracia Qualificada e Responsabilidade Política. São Paulo: LiberArs, 2018, p.78.

202 LORENCINI, Bruno. Democracia Qualificada e Responsabilidade Política. São Paulo: LiberArs, 2018, p.81.

${ }^{203}$ Difere, portanto, da accountability horizontal ou interinstitucional, na qual os governantes são controlados por outras instituições que tem habilitação técnica, além de expertise e legitimidade para realizar a atividade de controle. MORLINO, Leonardo. "Teoria da Democratização, Qualidade da Democracia e Pesquisa de Opinião: Ainda em 'Mesas Separadas"'. In: MOISÉS, José Alvaro. (org.) Democracia e 90
} 
A subsunção da teoria à prática, com a verificação da existência de responsiveness em cotejamento com a atuação dos governantes e instituições visando atender aos reais anseios sociais não constitui tarefa simples. No caso das propostas de campanha eleitoral uma das dificuldades reside no fato de que as propostas são realizadas em caráter bastante genérico, como assentaremos no capítulo seguinte. As dificuldades, contudo, não impedem que se identifique, de maneira objetiva, o cumprimento de promessas eleitorais, mediante balizamento normativo e técnico adequado. A fixação de indicadores estabelecidos de forma objetiva por meio de um órgão autônomo e independente é crucial para a efetividade do processo de análise.

Francisco de Vitoria ensinava que não havia razão para que o poder estivesse em outras mãos, que não o da comunidade, fruto do sufrágio e da observância do direito positivo. Vitoria aponta que a soberania popular se basta em si mesma, sendo o povo detentor do poder, dele não podendo renunciar ou permitir que seja dele despojado. Portanto, quando utilizado indevidamente o poder, cabe à sociedade civil recuperá-lo ${ }^{204}$. Acreditamos que é disso que se trata. O povo, pelas diversas razões que delineamos no capítulo 1, não tem exercido protagonismo na política, cabendo a "recuperação do poder", nas palavras de Francisco de Vitoria. A retomada de poder que sugerimos, evidentemente, não se dá pela força, até porque estamos discutindo hipóteses e implementações em ambiente democrático. O reforço democrático vem do aumento do poder da cidadania pelas vias institucionais.

Desta forma, a resposta à indagação supra estaria em fortalecer a manifestação formal cidadão, expressa pelo exercício do direito de sufrágio, tendo por horizonte a delimitação das normas constitucionais. O vínculo político-eleitoral deixaria de ser apenas um elemento procedimental para a formação de governo, passando a eleição a representar não apenas o direito à nomeação para o cargo de Chefia do Poder Executivo, mas a determinação para cumprimento dos compromissos assumidos à luz dos valores constitucionais - ou ao menos a busca por sua implementação - sob pena de efeitos jurídicos adrede previstos em lei ou no próprio compromisso.

Confiança - Por que os Cidadãos Desconfiam das Instituições Públicas? São Paulo: Editora Universidade de São Paulo, 2010. 304 p. 39-40.

204 "Pues, si antes que los hombres se reunissen em ciudades nadie era superior a los demás, no existe motivo alguno por el que em la asamblea y conclave civil alguén reclame para sí el poder sobre los demás". VITORIA, Francisco de. Relectio de Postestate Civili. Estudios sobre su Filosofía Política. Edición crítica por Jesús Cordero Pando. Corpus Hispanorum de Pace Segunda Serie. Madrid: Consejo Superior de Investigaciones Científicas, 2008, vol. 15, p. 25. 
Existe, pois, um plexo de elementos que devem ser alinhados para que se atinja uma democracia deliberativa ou responsiva. Parte-se da Constituição, que especialmente em normas de natureza programática, indica genericamente o caminho a ser trilhado pela administração. Em um segundo estágio, a legislação, atenta aos mandamentos e limites constitucionais, produzirá, embora ainda em caráter impessoal e genérico, um recorte menor do objetivo político-constitucional. Em um terceiro grau, a concreção das normas, por meio de decretos e políticas públicas, deve resultar das escolhas políticas correspondentes ao momento vigente. A Constituição permanece, as leis sofrem modulações, e os governos vão se alternando, realizando manobras dentro deste espectro de poder.

\subsection{O Poder Judiciário e o controle político da representação.}

O Direito Constitucional classifica as constituições quanto à extensão e finalidade entre constituições sintéticas (negativas ou garantias) e analíticas (dirigentes). As primeiras estabelecem os princípios e normas gerais aplicáveis, organizam e limitam o exercício do poder estipulando direitos e garantias ${ }^{205}$. As constituições dirigentes, na expressão de José Joaquim Gomes Canotilho, não se limitam a organizar o poder, mas afirmam-se como um programa cogente para o futuro, impondo força diretiva ao direito constitucional, e em última análise, fornecendo um fundamento constitucional para a política.

Deste modo, o texto constitucional impõe expressamente o dever político de realizar determinadas tarefas e perseguir determinados fins. Por isso, segundo Bercovici, diante do receio de que a Constituição fosse deturpada pelo legislador, nas constituições dirigentes a tarefa decisória sobre as questões constitucionais recai sobre o Poder Judiciário. E considerando-se que os problemas relacionados à constituição dirigente invariavelmente recaem sobre a concretização constitucional, o papel do Poder Judiciário no controle de constitucionalidade torna-se fundamental ${ }^{206}$. Nestes moldes, para Bercovici a constituição passa a pretender que nela esteja abarcada a totalidade da política, o que seria prejudicial à própria política. Articula, assim, que seria mais saudável a busca de um

\footnotetext{
${ }^{205}$ MORAES, Alexandre de. Direito constitucional. São Paulo: Atlas, $25^{\circ}$ ed, 2010, p. 10.

${ }^{206}$ BERCOVICI, Gilberto. Constituição e Política: uma relação difícil. Lua Nova, São Paulo, nº 61, 2004. Disponível em http://www.scielo.br/pdf/ln/n61/a02n61.pdf. Acesso em 31/01/2019, pp. 10-12
} 
viés predominantemente instrumental da Constituição, limitada a organizar, delimitando competências e regulando os procedimentos ${ }^{207}$.

Parte-se, portanto, da realidade de que em constituições dirigentes, o Poder Judiciário é, com frequência, chamado a solucionar divergências de interpretação constitucional, sobretudo quando se trata de realizar uma leitura moral da constitucional e de uma atualização interpretativa de dispositivos constitucionais. Não cabe aqui analisar as técnicas de interpretação constitucional, bem como todas as demais questões ligadas ao denominado ativismo judicial. Importa colocá-lo com uma realidade, que demanda enfretamento, sobretudo porque em nossa proposta, que será delineada nos capítulos 4 e 5, o Poder Judiciário faz parte da equação.

O marco inicial de análise da atividade judicial contemporânea, com vistas ao enfrentamento das críticas que se apresentam ao ativismo, é a legitimidade racional do Poder Judiciário. Em um sistema democrático, ao Poder Judiciário caberá a defesa da Constituição e do ordenamento jurídico como um todo, bem como a proteção dos direitos fundamentais e sociais e o respectivo direito à tutela judicial ${ }^{208}$.

Fernando Capano, ao tratar do neoconstitucionalismo, reforça que a despeito da efetivação da releitura dos valores constitucionais que regem a sociedade contemporânea, o Poder Judiciário deve necessariamente ter por baliza estreita os limites normativos, preservando o "delicado equilíbrio institucional havido com as demais manifestações estatais 209.

Campilongo aponta a existência de três críticas comuns ao movimento em que os juízes passam a ter atuação política: parcialidade, contestação à lei e intromissão em

\footnotetext{
207 "Ao reduzir a importância da Teoria do Estado e da política, a Teoria da Constituição Dirigente, aliada ao momento histórico da "globalização", facilitou, por mais paradoxal que possa ser, a "dessubstancialização" da Constituição. (...) Torna-se corrente a tentativa de restaurar os fundamentos da legitimidade liberal-democrática, reforçando a normatividade dos direitos, sob a perspectiva do homem como indivíduo e entendendo a Constituição e a democracia como estruturas processuais, ou seja, busca-se uma legitimidade meramente processual. O problema é a ausência cada vez maior do elemento democrático como justificador da legitimidade, reduzido, com o auxílio das teorias processuais da Constituição, que levam em conta apenas o seu aspecto normativo, não político, a um simples procedimento de escolha de governantes". Idem, Ibidem, pp. 13-14.

${ }^{208}$ COSTA NETO, José Wellington Bezerra da. Protagonismo Judicial - Novo Ativismo e Teoria Geral da Função Jurisdicional. São Paulo: Leud, 2017, p. 134.

209 CAPANO, Fernando Fabiani. "O Poder Judiciário e o movimento do constitucionalismo. Reflexões sobre o ativismo judicial no contexto da doutrina da separação dos poderes". $180 \mathrm{f}$. Dissertação (Mestrado) - Faculdade de Direito. Universidade Presbiteriana Mackenzie. São Paulo, 2011, p. 148.
} 
funções que competem aos outros poderes democráticos. Ele próprio responde a essas críticas $^{210}$.

A parcialidade representa a "partidarização da atividade jurisdicional", na qual juízes cedem a pressões de grupos ou partidos políticos, o que segundo o próprio autor, se fundaria em uma premissa falsa, de que o a política não se reduz à atuação partidária.

Outra crítica reside na ideia de que o juiz-político se afastaria da decisão normativa visando fundamentar suas decisões em parâmetros ideológicos. O equívoco aqui implica em ignorar toda a hermenêutica constitucional para assumir que a aplicação da lei é estritamente objetiva, como se estivéssemos diante de uma ciência exata. Evidentemente deve-se negar legitimidade a interpretações arbitrárias e meramente subjetivistas. Todavia, daí não se permite caminhar ao extremo oposto em que a atividade jurisdicional refletiria uma "irretorquível lógica de aplicação da lei"211.

A terceira crítica refere-se ao fato de o Poder Judiciário se apresentar como arena política, substituindo os demais poderes. Campilongo aduz que os mecanismos de política tradicional não têm demonstrado capacidade de gerar consenso, de modo que as instituições políticas tradicionais - parlamento, governo, partidos, sistema eleitoral - tem abdicado ou delegado seu poder decisório, ciente do não atingimento da eficácia de suas decisões. Por tal razão podemos observar que a crítica a eventual desbordo ativista deve recair também sobre o próprio Poder Legislativo, que entremeia a legislação com uma série de conceitos abertos, que demandam integração interpretativa, de modo que o Poder Judiciário é obrigado a intervir exercendo sua função primária. Tal, naturalmente, não exonera o dever das Cortes de exercer com parcimônia a intervenção, de modo a não usurpar competências outras, como aquelas que cabem exclusivamente ao povo, impondo o exercício de self-restrain como um dos grandes desafios do Poder Judiciário contemporâneo. Lisowski afirma que a interferência excessiva dos tribunais em temas como inelegibilidade eleitoral conduz os eleitores a se preocuparem em menor profundidade com as questões políticas ${ }^{212}$.

210 CAMPILONGO, Celso Fernandes. Política, sistema jurídico e decisão judicial. São Paulo: Saraiva, 2 Ed., 2011, pp. 58-59.

${ }^{211}$ CAMPILONGO, Celso Fernandes. Política, sistema jurídico e decisão judicial. Op. Cit., p. 58.

${ }^{212}$ LISOWSKI, Telma Rocha. Mandato Parlamentar \& Crise de Representatividade: instrumentos de perda e reforma do sistema. Curitiba: Juruá, 2018, p. 192. Não nos alinhamos com esse entendimento na medida em que tal crítica só pode ser voltada às hipóteses em que o Poder Judiciário desborda dos limites normativos e não quando, atendendo exatamente ao comando legal que determina o preenchimento de cláusulas abertas, aplica o direito. 
Não nos alinhamos a esse entendimento na medida em que tal crítica só pode ser voltada às hipóteses em que o Poder Judiciário desborda dos limites normativos e não quando, atendendo exatamente ao comando legal, determina o preenchimento de cláusulas abertas, aplicando o direito, como nas hipóteses de interpretação quanto ao sentido e alcance de dispositivos da Lei da Ficha Limpa $\left(\operatorname{LC} n^{\circ} 135 / 201\right)^{213}$.

Encontra-se superada a doutrina que reputava que os chamados atos de governo, ou as escolhas políticas eram imunes ao controle jurisdicional. Isso porque todos os atos praticados pelo Poder Público demandam observância à legalidade procedimental e ao dever de motivação. Dentro destas balizas, o controle judicial é admitido ${ }^{214}$.

Talvez por isso exista também o receio da formação de uma ditadura de juízes, em relação aos quais não haveria controle externo, sobretudo quando se pensa no papel das Cortes Supremas, e também por lhes faltar legitimidade política, porquanto o acesso aos cargos não decorre do sufrágio.

Nino nega legitimidade democrática aos juízes, especialmente aqueles que não foram eleitos, mas sim designados, além do fato de que não estão sujeitos, em geral, ao cumprimento de mandatos fixos e não são responsáveis de forma direta ante a opinião pública. O tom da crítica é ainda mais elevado quando afirma que pressupor que juízes teriam melhores condições para resolver questões relacionadas ao direito implicaria em um certo "elitismo epistemológico", pois o atingimento de conclusões morais corretas pressuporia destreza intelectual $^{215}$.

Em resposta a esta apreciação, Bruno Lorencini afasta a tese de falta de legitimidade do Poder Judiciário pela ausência de eleição, argumentando que não seria o método de escolha o procedimento que garantiria a escolha popular, tendo em vista as diversas formas de assunção ao poder pelos representantes políticos, como eleições diretas, indiretas, diversos sistemas eleitorais, etc ${ }^{216}$. Podemos acrescentar ainda que se o povo, de

${ }^{213}$ Para análise do tema: STF, Ação Direta de Constitucionalidade n 29 DF, rel. Min. Luiz Fux, j. $16 / 02 / 2012$

${ }^{214}$ BUCCI, Maria Paula Dallari. Fundamentos para uma Teoria Jurídica das Políticas Públicas. São Paulo: Saraiva, 2013, p. 61.

215 NINO, Carlos Santiago. La constitución de la democracia deliberativa. Barcelona: Gedisa Editorial, 1997, p. 259-260.

216 "Isso nos serve para concluir que o fato de juízes não serem eleitos pelo povo para o cargo que ocupam - ao menos na maior parte dos sistemas jurídicos -, não serve como argumento válido para sustentar sua ilegitimidade democrática para decidir acerca de questões tidas como poítcias, especialmente no campo do judicial review, quando n3egam validade a uma lei ou a um ato oriundo dos poderes Executivo e Legislativo. Todavia, caso se entenda o contrário, é de se supor que sendo os juízes eleitos, aí estem têm sua legitimidade para decidir politicamente isenta de qualquer questionamento, mas isso também não nos parece verdadeiro. De fato, como assentamos, não é o método de escolha que define a legitimidade democrática". 
forma soberana, elegeu uma assembleia constituinte na qual conferiu poderes para a elaboração de constituição e nela foram estabelecidos e delimitados os poderes do Poder Judiciário, atuando os juízes dentro deste espectro de autorização constitucional e, mais adiante, legal, não vemos como poderia ser questionada a legitimidade democrática do Poder Judiciário para realizar o judicial review. Se a vontade do constituinte - reitero, escolhido pelo povo - inclinar-se no sentido de limitar o judicial review, poderá estabelecer obstáculos institucionais à revisão judicial, como impedir a declaração incidental de inconstitucionalidade ou determinar a submissão da decisão que declara a constitucionalidade ou a inconstitucionalidade de determinadas questões em controle concentrado, seja submetida ao referendo do parlamento. Portanto, negar a legitimidade democrática do Poder Judiciário implica em reduzir todo o complexo feixe de relações que envolvem a soberania popular a apenas um procedimento eleitoral, ignorando-se que a legitimidade advém diretamente do texto constitucional estruturado de maneira soberana pelo povo, excetuadas naturalmente as constituições outorgadas.

Há oposição também no que toca à diferença procedimental entre o direito e a política. Em síntese, enquanto o judicial review corresponde a um procedimento hermenêutico lógico-interpreatativo, a política sedimenta-se, em tese, na esfera do diálogo, do embate de ideias e da negociação. É certo, por conseguinte, que há diferenças. Porém, a mera existência de arena para discussão não necessariamente imporá maior convergência, como lembrou há pouco Campilongo.

É certo que o administrador tem grande margem de discricionariedade na escolha das políticas públicas. Nesta esfera inclusive o Poder Judiciário não deve ingressar. Isso, porém, não permite concluir que o Poder Judiciário não possa verificar a existência de cumprimento das finalidades, o atendimento da eficiência, nos termos não apenas autorizados, mas determinados pelas normas legais.

Costa Neto lembra que sempre que se estabelece um fim a ser perseguido por um órgão, são erigidas automaticamente soluções hierárquicas que compõem um quadro de alternativas possíveis, gerando uma vinculação teleológica, que constitui um elemento comum tanto ao administrador, como ao julgador. Portanto, pode ser identificada a melhor solução possível, e será ainda, passível, de reanálise quer pelo órgão de jurisdição 
superior $^{217}$. Por vezes, o legislador já tem elementos para indicar o melhor caminho para o atingimento de um determinado fim, mas por vezes não. E nestas oportunidades, assentar que a discricionariedade não poderia ser objeto de apreciação pelo Poder Judiciário implicaria em negar o direito ou negar que o administrador estivesse vinculado ao fim indicado na lei. A discussão, portanto, centra-se em dois pilares os fins políticos do Estado e os meios necessários para alcança-los.

A discricionariedade situa-se na intersecção entre o Direito Constitucional, o Direito Político, o Direito Administrativo e o Direito Processual. Não se ignora que a transferência da discricionariedade do âmbito eminentemente político para o âmbito jurídico-administrativo, e por consequência, ao Poder Judiciário, traz em seu bojo alguns riscos, mas que sopesados, apresentam vantagens como aumento da capacidade de solução de conflitos, flexibilização na aplicação da lei, maior concretude aos direitos fundamentais, etc.

É importante ter presente que a discricionariedade não implica em exercícios de juízo desvinculados da lei. Esta visão encontra-se superada, na medida em que o juízo de conveniência e oportunidade, elementos clássicos da discricionariedade, pauta-se dentro de uma lógica normativa. Portanto, o juízo de discricionariedade corresponderá a uma atividade hermenêutica, ainda que mais flexível, visando superar lacunas e contrastes.

Até aqui nos parece possível concluir que o enlace entre o constitucionalismo e democracia é inerente à existência de conflitos. Por vezes, o fortalecimento do constitucionalismo e dos standarts legais podem limitar o desenvolvimento e avanço do processo democrático. Em outras oportunidades o excesso de democracia pode vir a enfraquecer o constitucionalismo. Neste sopesamente o Poder Judiciário cumprirá importante papel de equilíbrio. Criança de até 5 anos de idade

Isso acontece, por exemplo, com a existência de vagas para creches. A Constituição Brasileira, em seu artigo 208, IV, afirma ser dever do Estado prover a educação infantil às crianças até 5 anos de idade em creche e pré-escola. Não cabe ao Ministério Público, tutelando o interesse de menores, provocar o Poder Judiciário para indicar de qual forma o Poder Público deve prover a suficiência de vagas em creches. Não cabe a escolha sobre construção de creches próprias, realização de parcerias com entidades não governamentais ou mesmo pagamento de bolsas para que as próprias famílias escolham a melhor forma

${ }^{217}$ COSTA NETO, José Wellington Bezerra da. Protagonismo Judicial - Novo Ativismo e Teoria Geral da Função Jurisdicional. São Paulo: Leud, 2017, p. 504. 
para que a criança seja tutela enquanto os pais não estão em casa, como, por exemplo, com a utilização do valor para que terceira pessoa cuide da criança. Tais alternativas se inserem exclusivamente na esfera de discricionariedade do Poder Público. Todavia, isso não impede que à míngua de qualquer alternativa que implique no oferecimento de vagas suficientes, o Ministério Público provoque o Poder Judiciário para exigir a prática de condutas da Administração Pública. Em síntese, embora os meios caibam ao administrador dentro da esfera de discricionariedade, o resultado final pode ser exigido, tendo em vista a forma como garantido o direito ${ }^{218}$.

Outro exemplo que nos acorre trata da perda do mandato por "infidelidade partidária”. No Brasil, nos cargos cuja eleição é proporcional, a Lei dos Partidos Políticos brasileira (Lei Federal $n^{\circ}$ 9.096/95) determina que o parlamentar que se desfiliar do partido, perderá o mandato, excetuada a comprovação de justa causa. A lei considera como justa causa para a desfiliação partidária, a hipótese de "mudança substancial ou desvio reiterado do programa partidário" 219 .

Qual seria a razão deste dispositivo? O parlamentar foi eleito mediante filiação partidária, partindo-se do pressuposto da vedação das candidaturas avulsas, logo, tem ele responsabilidade com os eleitores que o elegeram, com alicerce no programa daquele partido. Assim, se o partido altera de forma substancial o programa, tem o parlamentar

218 Criança de até cinco anos de idade - atendimento em creche e em pré-escola - sentença que obriga o município de São Paulo a matricular crianças em unidades de ensino infantil próximas de sua residência ou do endereço de trabalho de seus responsáveis legais, sob pena de multa diária por criança não atendida - legitimidade jurídica da utilização das "astreintes" contra o poder público - doutrina jurisprudência - obrigação estatal de respeitar os direitos das crianças - educação infantil - direito assegurado pelo próprio texto constitucional (cf, art. 208, iv, na redação dada pela ec no 53/2006) - compreensão global do direito constitucional à educação - dever jurídico cuja execução se impõe ao poder público, notadamente ao município (cf, art. $211, \S 2^{\circ}$ ) - legitimidade constitucional da intervenção do poder judiciário em caso de omissão estatal na implementação de políticas públicas previstas na constituição - inocorrência de transgressão ao postulado da separação de poderes - proteção judicial de direitos sociais, escassez de recursos e a questão das "escolhas trágicas" - reserva do possível, mínimo existencial, dignidade da pessoa humana e vedação do retrocesso social - pretendida exoneração do encargo constitucional por efeito de superveniência de nova realidade fática - questão que sequer foi suscitada nas razões de recurso extraordinário princípio "jura novit curia" - invocação em sede de apelo extremo - impossibilidade - recurso de agravo improvido. (STF, ARE 639.337/SP, $2^{\mathrm{a}}$ T., rel. Min. Celso de Mello, d. j. 23.8.2011).

${ }^{219}$ Art. 22-A, parágrafo único, I, da Lei n 9.096/1995, com redação dada pela Lei n ${ }^{\circ} 13.165 / 2015$, que transformou em lei o artigo $1^{\circ}$, parágrafo $1^{\circ}$, III, da Resolução TSE $n^{\circ}$ 22.610/2007. A jurisprudência tem identificado uma via bastante estreita para a configuração da mudança substancial ou desvio reiterado do programa partidário, que necessariamente deveria advir de modificações estatutárias que flagrantemente alterassem de forma considerável os programas e ideologias do partido político. Nesse sentido: TRE-SP, Processso n 957-47.2015.626.0000, rel. André Guilherme Lemos Jorge, v.u., DJE 26/11/2015. Em sentido contrário, aceitando a prática política contrária ao programa, ainda que sem alteração dos estatutos como suficiente para o reconhecimento da justa causa, TRE-SP, petição ${ }^{\circ}$ 2286-36.2011.6.26.0000, rel. designado Penteado Navarro, v.m., DJE 01/10/2010. 
legitimidade para desvencilhar-se do partido que não mais atende ao programa que o elegeu e procurar outra agremiação.

Embora nosso estudo volte-se para as candidaturas aos cargos do Poder Executivo, e tal dispositivo não possa ser aplicado aos cargos cuja eleição ocorre pelo sistema majoritário, como já assentado pelo Supremo Tribunal Federal ${ }^{220}$, já que cargo pertence ao eleito e não ao partido, é possível compreender a mesma ratio, de que ontologicamente deveria existir uma penalidade para aquele que se afasta dos programas vigentes ao tempo da eleição.

Passemos à análise mais detida do vínculo que se estabelece entre o eleitor e representante em decorrência do processo eleitoral.

${ }^{220}$ Ação Direta de Inconstitucionalidade (ADI) 5081, de relatoria do ministro Luís Roberto Barroso, julgada em 27/05/2015, fixou a tese: “A perda do mandato em razão da mudança de partido não se aplica aos candidatos eleitos pelo sistema majoritário, sob pena de violação da soberania popular e das escolhas feitas pelo eleitor". 


\section{PROPOSIÇÕES ELEITORAIS E SUA RELEVÂNCIA NAS CAMPANHAS POLÍTICAS}

\subsection{Eleições e direito de voto.}

Os direitos políticos abrangem o direito de participar do processo político como um todo, abarcando o direito ao sufrágio, que inclui o voto periódico, livre, direto, secreto e igual, bem como o direito à autonomia e liberdade - interna e externa corporis - dos partidos políticos ${ }^{221}$. O sufrágio e o voto são os intitutos que devemos analisar para efeito da presente pesquisa.

A palavra voto tem origem latina (votum) e correspondia, inicialmente, a um desejo íntimo de caráter religioso. Na esfera política o voto representa o desejo de escolha de um representante, de um partido político, de uma proposta, etc ${ }^{222}$.

O voto é o instrumento por meio do qual o eleitor legalmente habilitado exerce, por meio físico ou digital, seu direito político ativo, em observância ao primado da soberania popular. O sufrágio, embora não exista prejuízo em ser empregado como sinônimo de voto ou direito de votar, para alguns corresponde a um plexo de direitos mais amplo que engloba o direito de voto, mas abrange também a participação política junto aos representantes, vale dizer, o exercício da "democracia deliberativa" com viés à responsividade democrática.

O direito ao sufrágio abrangendo aí naturalmente o direito de voto tem origem nos movimentos que visavam a derrubada da monarquia e independência de colônias, especialmente no final do século XVIII. Na Inglaterra, com a edição da Bill of Rights, aos auspícios da Revolução Gloriosa, tem-se a primeira norma escrita que se referia ao direito de sufrágio, assegurando a necessidade de realização de eleições para que fossem escolhidos os representantes. Nos Estados Unidos o primeiro documento que registrou o direito de sufrágio foi a Declaração de Direitos da Virgína em 1776. Na França, na esteira da Revolução, foi a Constituição de 1793 que elevou o sufrágio a condição de direito ${ }^{223}$.

${ }^{221}$ MENDES, Gilmar Ferreira e BRANCO, Paulo Gustavo Gonet. Curso de Direito Constitucional. 12 ed. rev. e atual. São Paulo: Saraiva, 2017, p. 753.

222 CARVALHO, Volgane Oliveira. Direitos Políticos no Brasil. O Eleitor no Século XXI. Curitiba: Juruá Editora, 2016, p. 58.

${ }^{223} \mathrm{O}$ voto será capacitário quando exige do eleitor uma característica pessoal, como por exemplo, não ser analfabeto ou ter concluído estudos em determinado nível. O voto censitário legitima ativa e/ou passivamente o cidadão que reúne determinados requisitos econômicos como renda, propriedades ou títulos 
Na França do final do Século XVIII, a burguesia desconfiava das eleições, pois ao mesmo tempo em que queria tirar a aristocracia do poder, temia que as eleições dessem poder às massas $^{224}$. No Brasil a Constituição de 1824 assegurava o direito de voto, censitário e capacitário $^{225}$, a representantes eleitos que, posteriormente e de forma indireta, elegeriam os deputados e senadores. Na Espanha, a primeira Constituição que previa expressamente o direito de sufrágio foi editada em 1812, mas conferido apenas aos homens ${ }^{226}$.

No século XX o constitucionalismo consagrou a soberania popular pela Constituição Mexicana de $1917^{227}$ e pela Constituição Alemã de Weimar, em $1919^{228}$. Em âmbito mundial, a Declaração Universal dos Direitos Humanos de 1948, ao tratar dos Direitos Políticos, no artigo XXI garantia a todo homem o "direito de tomar parte no governo de seu país, diretamente ou por intermédio de representantes livremente escolhidos". O item 3 do dispositivo assinala que "a vontade do povo será a base da autoridade do governo". A vontade deverá ser expressa em eleições periódicas e legítimas, por sufrágio universal, por voto secreto ou processo equivalente, observada a liberdade do voto $^{229}$. O Pacto Internacional de Direitos Civis e Políticos de 1966, em seu artigo 25, vai além. Não se trata mais de garantir a vontade do povo como base da autoridade de governo escorada na democracia eleitoral ou procedimental. Passa-se a exigir que o povo participe da "condução dos assuntos públicos, diretamente ou por representantes livremente

de nobreza. CARVALHO, Volgane Oliveira. Direitos Políticos no Brasil. O Eleitor no Século XXI. Curitiba: Juruá Editora, 2016, pp. 65, 67 e 74.

224 “(...) les libéraux se sont longtemps méfiés de l'élection pour ôter le pouvoir à aristocratie, ne voulait pas qu'elle donnait un moyen d'action considérable aux masses populaires: la bourgeoisie, qui se servait des élections pour ôter le pouvoir à l'aristocratie, ne voulait pas qu'on le lui otât à ele-même de la même façon” DUVERGER, Maurice. Institutions Politiques et Droit Constitutionnel - Les grands système politiques. Op. Cit., p. 98.

${ }^{225}$ Art. 92. São excluídos de votar nas assembléias paroquiais: $1^{\circ}$ ) Os menores de vinte e cinco anos, nos quais não se compreendem os casados e oficiais militares, que forem maiores de vinte e um anos, os bacharéis formados e clérigos de ordens sacras; $2^{\circ}$ ) Os filhos-família que estiverem na companhia de seus pais, salvo se servirem ofícios públicos; $3^{\circ}$ ) Os criados de servir, em cuja classe não entram os guarda-livros e primeiros caixeiros das casas de comércio, os criados da Casa Imperial que não forem de galão branco e os administradores das fazendas rurais e fábricas; $4^{\circ}$ ) Os religiosos e quaisquer que vivam em comunidade claustral; $5^{\circ}$ ) Os que não tiverem de renda líquida anual cem mil réis por bens de raiz, indústria, comércio ou empregos.

226 Disponível em: < http://www.congreso.es/constitucion/ficheros/historicas/cons_1812.pdf $>$. Acesso em 06/02/2019. As mulheres obtiveram o direito de votar apenas na Constituição de 1931.

227 Art. 39. "La soberanía nacional reside esencial y originariamente en el pueblo. Todo poder público dimana del pueblo y se instituye para beneficio de éste. El pueblo tiene en todo tiempo el inalienable derecho de alterar o modificar la forma de su gobierno". Disponível em: <https://archivos.juridicas.unam.mx/www/bjv/libros/6/2802/8.pdf>. Acesso em 06/02/2019.

${ }^{228}$ Art. $1^{\circ}$. (...) "Die Staatsgewalt geht vom Volke aus" A autoridade do Estado deriva do Povo (tradução nossa). Disponível em: <http://www.documentarchiv.de/wr/wrv.html\#ERSTER_ABSCHNITT>. Acesso em 06/02/2019.

${ }^{229}$ COMPARATO, Fabio Konder. A Afirmação Histórica dos Direitos Humanos. São Paulo: Saraiva, 6 ed., 2008, p. 238. 
escolhidos", bem como aos direitos de "votar e de ser eleito" e "ter acesso, em condições de igualdade, às funções públicas" ${ }^{\text {230 }}$. Evidencia-se, portanto, que em âmbito global a democracia participativa e representativa é consagrada como um direito humano ${ }^{231}$.

A consolidação constitucional do direito de voto não implica em dizer que não existiam eleições anteriormente à consagração constitucional do sufrágio. No Brasil, por exemplo, o primeiro registro de eleição teria ocorrido em 1532, na Vila de São Vicente, para escolha de representantes da Câmara da Vila ${ }^{232}$. Não cabe aqui realizar o aprofundamento da questão, mas é certo que a expansão do sufrágio até que se atingisse a universalidade, com direito a voto de analfabetos, mulheres, e independente de renda ocorreu apenas no século XX em diversos países.

O momento eleitoral, portanto, presta-se a constituir a autoridade governanamental, dentro de um complexo procedimento político que, conforme lição de Caggiano, traduz "preferências eleitorais em votos e os votos, na distribuicçao de cadeiras parlamentares ou na identificação da personagem a ocupar a chefia do Governo"233.

As eleições competitivas representam o núcleo duro das democracias liberais procedimentais, sendo associadas a expressões como "pedra angular"234 e "coração" da democracia procedimental ${ }^{235}$. O processo eleitoral normalmente recebe grande atenção acadêmica em relação aos sistemas eleitorais e as regras de exercício da campanha eleitoral, mas poucas luzes em relação ao conteúdo das propostas eleitorais.

\subsection{As campanhas eleitorais.}

${ }^{230}$ Segundo Comparato, as Constituições que não reconhecem os institutos de democracia direta como plebiscito, referendo, iniciativa popular legislativa e orçamento participativo, entre outros, não apenas são ilegítimas como contrárias à ordem internacional dos direitos humanos. COMPARATO, Fabio Konder. $A$ Afirmação Histórica dos Direitos Humanos. Op. Cit., pp. 321-322.

${ }^{231}$ Neste sentido, Winston Churchill afirmou: "O fundamento de qualquer democracia é que o povo tenha o direito de votar. Privá-lo desse direito é escarnecer de todas as belas frases tantas vezes utilizadas. Na base de todas as contribuições para a democracia está o homem comum, que entra na pequena câmara, com um pequeno lápis, e faz uma pequena cruz num pequeno pedaço de papel. Nenhuma retórica ou discussão pode encobrir a extraordinária importância desse gesto. O povo tem o direito de escolher seus representantes de acordo com seus desejos e sentimentos." GILBERT, Martin. Winston Churchill: uma vida. Volume II. (Trad. Elisa Nogueira). São Paulo: Leya Brasil, 2016, kindle edition, posição 6759.

${ }^{232}$ CARVALHO, Volgane Oliveira. Direitos Políticos no Brasil. O Eleitor no Século XXI. Op. Cit., p. 76.

${ }^{233}$ CAGGIANO, Monica Herman Salem. Sistemas Eleitorais x Representação Política. São Paulo: Centro Gráfico do Senado Federal, 1987, p. 39.

${ }^{234}$ DUVERGER, Maurice. Institutions Politiques et Droit Constitutionnel - Les grands système politiques. Op. Cit., p. 99.

${ }^{235}$ MARAVALL, José María. Las promesas políticas. Barcelona: Galaxia Gutemberg, 2013, p. 29. 
As campanhas eleitorais correspondem ao conjunto de atividades lícitas de propaganda eleitoral, durante um determinado período legal, no qual os partidos, coalizões e grupos eleitorais atuam com o objetivo de expor seus programas de governo e princípios ideológicos para arregimentar apoio explícito dos eleitores a uma determinada eleição. As campanhas refletem períodos em que os partidos políticos, observando o regramento legal, apresentam seus candidatos visando a obtenção de votos suficientes para assunção legítima a cargos eletivos. No Brasil, o Tribunal Superior Eleitoral definiu o ato de propaganda eleitoral como aquele voltado à escolha de quem seria o candidato mais apto ao exercício da função pública ${ }^{236}$.

O objetivo é a vitória no pleito por meio de um procedimento transparente e igualitário, no qual os partidos/candidatos possam convencer os eleitores de que possuem melhores propostas e de que estão mais bem preparados em comparação com os demais candidatos, mobilizando os simpatizantes, desmobilizando os adversários e atraindo os indecisos ${ }^{237}$. As campanhas eleitorais permitem que se estabeleçam verdadeiros diálogos entre os cidadãos e os candidatos ${ }^{238}$. A campanha eleitoral, portanto, constitui um processo complexo que, em última análise, objetiva fazer com que o eleitor adira a um determinado candidato $^{239}$.

236 “ “...]. Entende-se como ato de propaganda eleitoral aquele que leva ao conhecimento geral, ainda que de forma dissimulada, a candidatura, mesmo que apenas postulada, a ação política que se pretende desenvolver ou razões que induzam a concluir que o beneficiário é o mais apto ao exercício de função pública. Sem tais características, poderá haver mera promoção pessoal, apta, em determinadas circunstâncias a configurar abuso de poder econômico, mas não propaganda eleitoral. [...]." (Ac. no 16.183, de 17.2.2000, rel. Min. Eduardo Alckmin).

${ }^{237}$ MARAVALL, José María. Las promesas políticas. Op. Cit., p. 34.

238 "En primer lugar, la representación podría concebirse como una delegación para continuar la discusión a partir del punto alcanzado por los electores durante el debate condujo a la elección de representantes. Durante la campaña electoral, los representantes prometen defender valores particulares y ideas en una discusión que llevan a cabo entre ellos mismos y, en la medida que sea posible, también con las personas cuyos votos están siendo seducidos. El debate en una campaña electoral alcanzaría un punto en el cual requeriría parar debido a la necesidad de efectuar la votación. El resultado de la elección podría significar el triunfo de alguna de las posiciones ofrecidas al electorado. Si la representación es indivisible como en una elección presidencial -, el representante debería estar obligado a implementar esa posición y continuar su próprio conocimiento técnico para conocer métodos específicos de puesta en práctica de las propuestas por las cuales fue elegido. Si la representación es divisible - como cuando un cuerpo colectivo es eligido - esse cuerpo debería busca reflejar el apoyo de cada posición recibida de los electores y los representates deberían continuar su deliberación colectiva a partir del punto al cual llegó la ciudadanía al final de la campaña electoral tratando de alcanzar mayor especificidade de las posiciones en cuestión através de la discusión y el necesario conocimiento técnico". NINO, Carlos Santiago. La constitución de la democracia deliberativa. Op. Cit., pp. 184-185.

239 "Una campaña es un conjunto de decisiones estratégicas para conseguir los votos de los ciudadanos. Los candidatos, los partidos y los assessores analízan sus acciones pasadas, presentan sus estratégias presentes y sus intenciones futuras para 'intentar convencer a las audiências de que tomen um tipo de decisão en lugar de otra (Austen-Smith, 1992:47). En dicho proceso de convencimento, las elites políticas necesitan de dos elementos: informatión y campaña electoral. El primer es el 'input', la materia prima, que los candidatos utilizarán para convencer a los votantes. El segundo es el contexto en el que se produce dicho 
Em geral os candidatos apresentam as mais diferentes visões para os problemas sociais e econômicos, ofertando igualmente distintas soluções. $\mathrm{O}$ debate político abrangente pressupõe o engajamento discursivo amplo de uma pluralidade de interlocutores. Diferentes especialistas sustentarão também as diversas correntes políticas e econômicas apresentadas. Neste cenário, muitas vezes caótico, agregado recentemente pelas fake news, notícias falsas que são compartilhadas com incrível rapidez na internet, os eleitores devem realizar suas opções políticas.

Segundo Fernando Neisser, as campanhas eleitorais possuem quatro funções essenciais: (1) permitir a legitimação dos eleitos; (2) chamar os cidadãos a exercer o múnus público democrático de escolha dos próprios representantes na formação do governo; (3) mobilizar os eleitores que se alinham com os candidatos/partidos gerando uma teia de organização social de sustentação; (4) difundir informação na sociedade na medida em que os candidatos apresentam suas propostas e pontos negativos dos demais candidatos ${ }^{240}$.

Para Ferran Martínez i Coma a campanha eleitoral possui dupla função. Ao mesmo tempo em que é uma ferramenta de publicidade é também uma ferramenta de controle. É instrumento de publicidade porque é por meio dela que o candidato apresenta informações a seu respeito e são realizadas as suas propostas. Concomitantemente, funciona como medida de controle tanto dos cidadãos em relação aos políticos, como dos políticos em relação aos cidadãos. Os cidadãos têm o poder de sancionar os políticos negando-lhes o voto. Os políticos, ao réves, não dispõem de tal poder, de modo que o único controle que podem fazer é tentar induzir os eleitores a aderirem à visão política que eles apresentam ${ }^{241}$. Por isso, as campanhas eleitorais representam instrumento de accountability na medida em que os planos de governo devem oferecer, em tese, transparência sobre as intenções do candidato para que possam ser cotejados com as ações efetivamente adotadas após a assunção ao cargo eletivo.

A propaganda, a publicidade e o marketing são instrumentos dos quais se valem os políticos para veiculação da campanha eleitoral, com o escopo de fazer chegar sua mensagem aos cidadãos.

Pode ser traçada uma distinção entre propaganda e publicidade, no sentido de que aquela tem por objetivo persuadir informando, ao passo que esta, pretende o mesmo, mas

‘input”". MARTÍNEZ i COMA, Ferran. ¿Por qué importan las campañas electorales? Colección $<$ Monofrafías>, n 260. Centro de Investigaciones Sociológicas. Madrid: EFCA S.A., 2008, p. 1.

${ }^{240}$ NEISSER, Fernando Gaspar. Crime e Mentira na Política. Belo Horizonte: Editora Forum, 2016, pp. 61-64.

${ }^{241}$ MARTÍNEZ i COMA, Ferran. ¿Por qué importan las campañas electorales? Op. Cit., pp. 5-8. 
sem informar. Deste modo, a comunicação política representa a difusão de conteúdo programático enquanto a comunicação comercial ou publicitária implica na atribuição de qualidades, muitas vezes subjetivas, em relação a um determinado produto. Portanto, enquanto a propaganda é informativa, a publicidade é qualificativa ${ }^{242}$. No meio político a comunicação representaria a apresentação de diretrizes principiológicas e governamentais, e a publicidade a qualificação de um candidato como mais preparado, mais inteligente, honesto, etc. Para este trabalho não utilizaremos referida distinção, na medida em que para o objeto desta pesquisa o relevante é apenas o "conteúdo" de determinadas propostas eleitorais. Em uma campanha são apresentadas também razões políticas e ideológicas ${ }^{243}$. Nos ocuparemos apenas das primeiras neste estudo.

O marketing é definido como um conjunto de atos que representam o planejamento e a execução do conceito, preço, promoção e distribuição de ideais, bens e serviços, criando intercâmbios que satisfaçam ao indivíduo e à organização. Em sua derivação política, o marketing representa o estudo do eleitorado com o objetivo de ofertar candidatos e programas organizacionais, de forma a corresponder à expectativa dos eleitores. Por fim, o marketing eleitoral, de aplicação mais limitada, tem por objeto apenas o período eleitoral e por escopo o sucesso em um determinado pleito ${ }^{244}$.

A "propaganda política" agrega todo tipo de manifestação relacionada com a organização, direção e administração de estados ou nações. Abrange, de forma mais específica, a "propaganda eleitoral”, que ocorre no período de eleições. A "propaganda partidária”, que corresponde às manifestações dos partidos políticos fora do período eleitoral visando apresentar suas diretrizes e realizações ${ }^{245}$ e a "propaganda intrapartidária”, realizada interna corporis no partido político em que os pretensos candidatos se apresentam visando arregimentar apoiadores para as convenções partidárias

${ }^{242}$ DÍAZ, Angel Eduardo Alvarez. "Los contenidos de la propaganda electoral y la protecction de la racionalidad politica del elector". In: MAGALLANES, Manuel Vicente (coord.) Propaganda Política Partidos y Sistema Electoral. Consejo Supremo Electoral, Colección del Cincuentenario 2. Caracas: Miguel Angel García e Hijo, s.r.l.: 1987, p. 69.

243 “Cuando un partido dice lo que hará en el gobierno estará dando razones políticas para que se vote por él. Cuando expone su concepción del mundo, da razones ideológicas”. Idem, Ibidem, pp. 69-70.

${ }^{244}$ LUQUE, Teodoro. Márketing Político Un análisis del intercambio político. Barcelona: Editorial Ariel, 1996, p. 9.

${ }^{245}$ Por exemplo, a Lei dos Partidos Políticos (Lei Federal $n^{\circ}$ 9.096/95) previa em seu artigo 45 inserções em transmissão por rádio e televisão para difundir programas partidários, transmitir mensagens aos filiados, divulgar a posição do partido em relação a determinados temas e promover a participação política feminina. Contudo, tal dispositivo foi expressamente revogado pela Lei Federal n ${ }^{\circ}$ 13.487/2017. 
ou prévias, não integram este estudo ${ }^{246}$. Apenas a propoganda eleitoral, realizada no bojo de campanhas eleitorais, reflete-se no objeto da presente pesquisa.

A política e a linguagem possuem estreita relação. Sartori chama à atenção para o fato de que na política a linguagem, muitas vezes, não se presta a exteriorizar os pensamentos, mas sim ocultar o que realmente se pensa ${ }^{247}$. A linguagem corresponde a um forte instrumento de retórica do poder invisível ${ }^{248}$. Daí a relevância da propaganda eleitoral que tem por escopo o convencimento de corpo eleitoral a votar em determinados candidatos/partidos em detrimento de outras opções.

Atualmente as campanhas eleitorais são altamente profissionalizadas, com custo elevado, contando com gerenciamento de consultores de publicidade e marketing, imagem, aceitação pública, etc.

A utilização da internet, especificamente das redes sociais ganhou grande espaço nos pleitos contemporâneos. O uso de modernas ferramentas de tecnologias e o aumento de gastos com publicidade tem modificado a forma de se fazer campanha eleitoral" ${ }^{249}$.

Entretanto, alguns estudos mostram que a utilização das redes sociais pelos candidatos tem se limitado ao atingimento de estratégias políticas e ao fornecimento de informações, inclusive propostas eleitorais. Infelizmente parece não haver um avanço para uma participação vertical mais ativa dos cidadãos. As comunicações realizadas por candidatos a cargos executivos não vinham se mostrando eficazes em relação a uma comunicação dialógica, ou seja, os candidatos realizam diversas publicações, mas pouco respondem a indagações ou formulam questões para manifestação dos cidadãos ${ }^{250}$. Atualmente este cenário tem se alterado. Cada vez mais devido à grande penetração e à rapidez da comunicação, as redes sociais, sobretudo o Twitter, tem se covertido não apenas em um canal direto entre representantes e representados, como em verdadeiro "diário pp. $75-76$

${ }^{246}$ NEISSER, Fernando Gaspar. Crime e Mentira na Política. Belo Horizonte: Editora Forum, 2016,

${ }^{247}$ SARTORI, Giovanni. A Teoria da Democracia Revisitada. Vol. 2. São Paulo: Ática, 1994, p. 9.

248 "Em sentido metafórico, o mascaramento ocorre sobretudo mediante a linguagem, que sendo oportunamente usada, permite ocultar o pensamento. Esse ocultamento pode se dar em dois momentos: ou usando uma linguagem para iniciados, esotérica, compreensível somente para os que integram o círculo, ou usando a linguagem comum para dizer o oposto do que se pensa ou para dar informações equivocadas ou justificativas distorcidas". BOBBIO, Norberto. Democracia e Segredo. Op. Cit., p. 53.

${ }^{249}$ MENEZES, Fernanda Montenegro de. "Marketing Político. Eleições Municipais de 2008". In: LEMBO, Cláudio (Coord.); CAGGIANO, Monica Herman Salem (Org.). Comportamento Eleitoral. Barueri: Manole, 2010, p. 230.

250 MUNIZ, Carlos et al. ¿Están los políticos políticamente comprometidos?: Análisis del compromiso político 2.0 desarrollado por los candidatos a través de Facebook. Cuadernos info. Santiago, n. 39, dic. 2016, pp. 138-139. Disponível $\quad$ em <https://scielo.conicyt.cl/scielo.php?script=sci_arttext\&pid=S0719-67X2016000200009\&lng=es\&nrm=iso>. Acesso em 21 de maio 2019, pp. 138-139. 
oficial" para veiculação de toda sorte da manifestação de natureza pessoal e governamental, em primeira mão ${ }^{251}$.

Trasladado o resultado do estudo para a questão das propostas eleitorais, compreende-se que propostas efetivamente são apresentadas pelas redes sociais, mas sem consulta prévia da opinião da população ou mesmo sem maiores esclarecimentos quando surgem questionamentos.

O sucesso de uma campanha eleitoral depende da concepção e execução de três elementos: imagem do partido, imagem do líder e as propostas de campanha, que abrangem as questões preferencialmente defendidas pelo partido e pontos específicos de determinada campanha eleitoral ${ }^{252}$. Dos três elementos nos interessa para esta pesquisa apenas o último.

Tratando-se de atos públicos de caráter político naturalmente são suscetíveis de regulação ${ }^{253}$, inclusive para que se cumpram os objetivos democráticos de paridade de armas aos candidatos.

A campanha eleitoral pode ser divida em campanha oficial e não oficial. A campanha oficial representa o momento legal em que o candidato já está habilitado e a legislação o autoriza a apresentar-se oficialmente ao corpo eleitoral com suas propostas e críticas pleiteando o sufrágio. Já a campanha não oficial importa em condutas diretas ou indiretas que tem por objetivo formar a convicção do eleitor para pleito futuro, sem especificamente realizar alusão a pedido de voto, o que implicaria, segundo e lei brasileira em propaganda antecipada, conforme redação do artigo 36-A da Lei n 9.504/97 (Lei das

${ }^{251}$ Modolo lembra que os políticos relatam conteúdo de seu cotidiano, como eventos oficiais, dados e estatísticas de seus governos, seus projetos políticos, buscando uma aproximação com os eleitores por meio de um diálogo informal. Trata-se de um projeto de "humanização" dos políticos, visando aproximá-los do eleitor. MODOLO, Artur Daniel Ramos. Hipertextualidade e relações dialógicas no gênero digital microblog político dos candidatos à presidêcia do Brasil nas eleições 2010. Dissertação de Mestrado Faculdade de Filosofia, Letras e Ciências Humanas, Universidade de São Paulo, 2011, p. 64-65.

${ }^{252}$ BOWLER, Shaun e FARELL, David M. “The Study of Election Campaigning”. In: Electoral Strategies and Political Marketing (Orgs.). NY: The Macmillan Press Ltd, 1992, p. 15.

${ }^{253}$ Sobre os fundamentos que justificam a necessidade de controle sobre os atos praticados em campanhas eleitorais: “(...): a) afectan al ejercicio de derechos fundamentales y liberdades públicas; b) tienen transcendencia sobre el procedimento de formación de opiniones y de selección de opciones políticas; c) inciden sobre el gasto publico tanto al ser beneficiários los partidos, coaliciones y agrupaciones de determinadas subvenciones, que se aplican a los gastos de campaña, como al permitírse el acceso gratuito a medios de comunicación y espacios publicitários de titularidad pública, y d) suelen reglamentarse de manera restrictiva para garantizar oportunidades materiales proporcionadas a los distintos actores em pugna (limitaciones, gastos y aportaciones privadas; control de encuestas y difusión de sondeos preelectorales em período oficial de campaña, p. ej.)" HERNÁNDEZ, Juan Carlos González. Derecho Electoral Español. Normas y Procedimiento. Madrid: Editorial Tecnos S/A, pp. 40-41. 
Eleições $)^{254}$. No Brasil o período eleitoral oficial inicia-se no trimestre anterior à eleição e termina com o ato de diplomação dos eleitos ${ }^{255}$.

Algumas dúvidas se apresentam rapidamente diante dos temas trazidos. As campanhas eleitorais realmente influem na decisão de escolha dos eleitorais? E se influem, a escolha é realizada com base na pessoa do candidato, em suas propostas ou em ambos?

Há uma regra não escrita, segundo a qual as propostas de campanha deveriam refletir aquilo que o governante realmente acredita que implementará em seu governo, ou ao menos, envidará esforços para tanto. Contudo, o descumprimento sistemático de tal norma tem gerado uma alteração comportamental, do modo que o comportamento normalmente esperado passa a ser o de descumprimento das propostas e a surpresa passa a representar o sentimento encontrado diante do cumprimento de propostas. Em síntese, o que deveria ser enfrentado como patologia do sistema, sob aspecto ideal, passa a ser admitido como normal e inclusive esperado.

\subsection{O processo de escolha de candidatos pelo eleitorado.}

O cidadão comum, ao tratar da política, volta-se primitivamente aos seus interesses pessoais e associativos mais próximos que, segundo Schumpeter, identifica reduzido senso de responsabilidade e falta de julgamento racional. Afirma o autor que o cidadão não se interessa em se capacitar e faz uso incipiente do abundante acesso à informação ${ }^{256}$.

O comportamento dos líderes políticos, de seu turno, também influi no comportamento dos eleitores e tem potencial para condicionar os resultados de uma campanha eleitoral. $\mathrm{O}$ voto muitas vezes será orientado pela representação que a figura do candidato significa. Imaginemos, por exemplo, uma eleição para cargo de chefia do Poder Executivo, que congregue quatro candidatos distintos. $\mathrm{O}$ candidato $\mathrm{X}$ é identificado como um protetor dos economicamente hipossuficientes e que promoverá a melhor distribuição de riqueza, enquanto o candidato $\mathrm{Y}$ é tido como defensor da atividade empresarial liberal, agenciando o desenvolvimento econômico. O candidato $\mathrm{W}$ propõe endurecimento da

${ }^{254}$ Artigo 36-A. Não configuram propaganda eleitoral antecipada, desde que não envolvam pedido explícito de voto, a menção à pretensa candidatura, a exaltação das qualidades pessoais dos pré-candidatos e os seguintes atos, que poderão ter cobertura dos meios de comunicação social, inclusive via internet:

${ }^{255} \mathrm{Na}$ Espanha a Ley de Ordenación del Regimen Electoral General define a campanha eleitoral oficial em seu artigo 50: “(...) el conjunto de actividades lícitas llevadas a cabo por los candidatos, partidos, federaciones, coaliciones o agrupaciones en orden a la captación de sufrágios”. Disponível em: <http://www.juntaelectoralcentral.es/cs/jec/loreg>. Acesso em 25/01/2018.

256 SCHUMPETER, Joseph A. Capitalismo, Socialismo e Democracia (Tradução Luiz Antônio Oliveira de Araújo). São Pulo: Editora Unesp, 2017, pp. 354-355. 
legislação penal e, por consequência, é tido como patrono das políticas de segurança pública. $\mathrm{O}$ candidato $\mathrm{Z}$ se apresenta com viés ponderado, e poderia evitar uma polarização em algumas questões, o que aproxima a ideia de promoção de equilíbrio sócio-economico.

Como os candidatos passam a ser identificados com essas características?

Em primeiro lugar às pesquisas que eles próprios realizam, de modo que pretendem dizer exatamente o que boa parte da população quer escutar, no que se valem fortemente dos meios de comunicação tradicionais, como a televisão e cada vez mais da mídia eletrônica, como redes sociais e grupos de aplicativos de comunicação.

A decisão do eleitor ao votar é composta por um conjunto de compromissos, promessas e respostas relativas aos problemas sociais, políticos e econômicos vigentes. Este processo demanda do eleitor interessado grande esforço. O eleitor pode recolher as informações apresentadas, avaliar, estudar e debater seu conteúdo para, por fim, optar por um determinado candidato ou proposta. Após a eleição o eleitor poderá ainda realizar uma avaliação que consiste em cotejar as propostas realizadas e a sua percepção sobre o cumprimento ou tentativa de observância das propostas.

A identificação dos eleitores com determinadas correntes de pensamento e o processo de escolha do candidato envolvem a teoria de processamento da informação, que trabalha com dois tipos de memória, de longa duração (long term memory), que registra o conhecimento geral do dia a dia, e a memória de curta duração (working memory) que representa uma pequena parte da memória de longa duração, em relação a qual a pessoa tem consciência em um determinado momento. A inter-relação entre estes componentes determinará em grande parte como a informação é processada. A memória de curta duração é limitada sob o aspecto quantitativo e também por trabalhar de forma serial, ou seja, novas informações somente podem ser adicionadas quando a informação antiga é perdida. Além disso, a memória de curta duração é lenta, de modo que leva tempo para que uma "working memory" evolua para "long term memory”. O modelo de associação de rede estipula que a memória de longa duração trabalha com uma séria de associações, envolvendo conceitos que são representados por pontos de intersecção ${ }^{257}$. Por exemplo: no Brasil, o termo Lava-Jato remete a associações com as palavras corrupção, políticos, Petrobrás e juiz Sérgio Moro. A força dos pontos de intersecção, ou seja, a intensidade e o

257 STEENBERGEN, Marco R. e LODGE, Milton. "Process Matters: Cognitive Models of Candidate Evaluation". In: MACKUEN, B. Michael e RABINOWITZ, George (Orgs.). Electoral Democracy. Michigan: The University of Michigan Press, 2003, pp. 127-129. 
período com o qual são mantidas as inter-relações variam de acordo com mecanismo de ativação, como frequência de notícias na mídia.

O processamento de informações envolve quatro estágios segundo Steenbergen e Lodge: (1) exposição e atenção; (2) decodificação; (3) avaliação; (4) registro. Marco Steenbergen e Milton Lodge dividem o processo de avaliação de candidatos políticos em três categorias: (1) modelos baseados na memória; (2) o modelo on-line; (3) modelos híbridos. O modelo baseado na memória aponta que os cidadãos avaliam os candidatos de acordo com a lembrança de fatos, números e atributos registrados na memória de longa duração, e após avaliá-los, chega a um veredito sobre o candidato, embora se trate de uma decisão maleável. O sistema on-line tem origem na percepção pessoal em relação ao reconhecimento social do candidato, ou seja, para além de apenas avaliar os atributos do candidato ao final de um processo, as pessoas atualizam suas impressões em relação a um candidato sempre que encontram nova informação a seu respeito, efetuando como um saldo em conta corrente. Atualizada a impressão, o indivíduo pode inclusive esquecer da informação que deu origem a ela ${ }^{258}$.

Outro elemento que não pode ser negligenciado no processo de escolha de candidatos é a perspectiva afetiva, pois por meio dele as associações serão relacionadas como positivas ou negativas.

A esse respeito, são interessantes as observações de Nadia Urbinati que diferencia o voto em relação a temas isolados, como ocorre no exercício dos instrumentos de democracia direta, da escolha de um candidato em um processo eleitoral, que é fruto de uma opinião política de longa duração ou de uma constelação de opiniões políticas representada pela atratividade de uma plataforma política ou um conjunto de propostas e ideias a serem aplicados em um determinado período ${ }^{259}$.

Discute-se, portanto, se as campanhas eleitorais são ou não relevantes para o resultado final dos pleitos. Alguns, como T. H. Holbrook ${ }^{260}$, advogam que grande parte da população já tem seus candidatos escolhidos antes mesmo do início das campanhas eleitorais, baseando-se nas impressões formadas paulatinamente e diante das condições

${ }^{258}$ STEENBERGEN, Marco R. e LODGE, Milton. Process Matters: Cognitive Models of Candidate Evaluation. Op. Cit., pp. 148-150.

${ }^{259}$ URBINATI, Nadia. Representative Democracy. Chicago: University of Chicago Presse, 2006, p. 31.

${ }^{260}$ HOLBROOK, Thomas M. Do Campaigns Matter? Contemporary American Politics. Thousand Oaks, California: Sage Publications, 1999, p. 43. 
econômicas vigentes. Entretanto, outros, como González ${ }^{261}$ e Martínez i Coma sustentam a importância das campanhas. Estes, com que nos filiamos, afirmam que grande parte dos eleitores decide se e como votar durante a campanha, ainda que a campanha preste-se apenas a reforçar a escolha realizada anteriormente. Além disso, a identificação partidária do eleitor em diversos países é cada vez menor, o apoio entre políticos se altera durante a campanha e a mídia gera uma grande quantidade de informações que pode ser utilizada pelos eleitores para orientar seu voto ${ }^{262}$, o que reforca a tese da relevância das campanhas eleitorais para o desfecho dos pleitos.

Em uma das primeiras pesquisas de intenção de voto para as eleições presidenciais em 2018 no Brasil, 33\% das pessoas estavam dispostas a votar branco ou nulo e $8 \%$ não responderam ${ }^{263}$. Trata-se de um percentual relevante para que as campanhas eleitorais pudessem dissuadir os eleitos da intenção de votar branco ou nulo e determinar a escolha dos indecisos.

A democracia funda-se no livre debate de ideias e na apresentação de propostas. Embora seja nosso dever reconhecer a influência da profissionalização da propaganda eleitoral por meio de instrumentos de publicidade, análise de pesquisas, lesividade e ofensividade da propaganda, não pretendemos realizar qualquer crítica a estes instrumentos. Para nós o problema não está no excesso de liberdade com que os candidatos/partidos apresentam suas propostas, ou se apresentam interpretações equivocada de fatos e dados, mas sim na falta de "falta de verificação das propostas quanto à extensão de seu cumprimento" e a "coercibilidade das propostas", fortalecendo-se o vínculo entre a cidadania e os candidatos.

A demagogia inunda as campanhas eleitorais gerando uma sensação de descrédito e desconfiança mútua, acirrando a polarização social ${ }^{264}$. A demagogia institucionalizada

${ }^{261}$ GONZÁLEZ, María Holgado. El Programa de Gobierno y sus Sistemas de Control. Valencia: Tirant Lo Blanch, 2008, p. 35.

${ }^{262}$ MARTÍNEZ i COMA, Ferran. ¿Por qué importan las campañas electorales? Op. Cit., p. 39.

${ }^{263}$ Pesquisa realizada pelo instituto IBOPE entre os dias 21 e 24 de junho de 2018. Disponível em: <http://www.ibopeinteligencia.com/noticias-e-pesquisas/jair-bolsonaro-fica-numericamente-a-frente-mastecnicamente-empatado-com-marina-silva-na-ausencia-de-lula-na-disputa-pela-presidencia-da-rep/>. Acesso em 26/10/2018.

264 “Embora analistas muitas vezes assegurem que demagogos são 'só falastrões' e que suas palavras não devem ser levadas demasiado a sério, um rápido exame dos líderes demagógicos mundo afora sugere que muitos deles de fato cruzam a fronteira entre palavras e ação. É por isso que a ascensão social de um demagogo ao poder tende a polarizar a sociedade, criando uma atmosfera de pânico, hostilidade e desconfiança mútua. As palavras ameaçadoras do novo líder têm um efeito bumerangue. Se a mídia se sente ameaçada, pode abandonar o comedimento e padrões profissionais, num esforço desesperado para enfraquecer o governo. E a oposição pode concluir que, pelo bem do país, o governo tem que ser afastado através de medidas extremas - impeachment, manifestações de massa, até mesmo golpe”. LEVITSKY, 
provoca um esgotamento do cidadão com a política, algo como uma certeza de que diante do fato de que todos os políticos mentem, não há razão para tentar melhor compreender os temas políticos, o que autorizaria a população a acreditar no que quiser, inclusive preferindo rejeitar a política e voltar-se para a própria vida pessoal ${ }^{265}$. Pesquisa realizada pelo Programa das Nações Unidas para o Desenvolvimento na América Latina em 2004, com base em dados colhidos no ano de 2002, apontou alto percentual de eleitores que acreditam que os candidatos mentem com o exclusivo objetivo de vencer o pleito eleitoral: Paraguai (84,9\%), Argentina (78,2\%), Brasil (74\%), Guatemala $(67,5 \%)$ e Colômbia $(69,3 \%)^{266}$.

Todo esse intrincado processamento interno de informações demanda um comportamento bastante ativo por parte dos cidadãos. No caso do mencionado modelo online, se o cidadão já possuir uma posição muito marcada em relação a um determinado candidato, terá dificuldade para refletir sobre argumentos e evidências contrárias ${ }^{267}$. Muitas vezes também é difícil para os cidadãos identificarem se melhorias em sua condição de vida devem ou não ser atribuídas à atuação dos políticos, o que corresponde à figura do voto retrospectivo, ou seja, a análise da administração passada como forma de orientar a votação futura. Em outras palavras, não é simples identificar a influência de condições exógenas na condição pessoal do indivíduo ${ }^{268}$.

A incerteza quanto ao resultado final das eleições não afasta a probabilidade de que determinados resultados ocorram mediante determinadas condições e a vista do conteúdo de discursos. Por exemplo, em um cenário econômico de altos índices de desemprego, um discurso de aumento de impostos e redução da oferta de serviços públicos tenderia a ser rejeitado pela população. Neste mesmo panorama de crise econômica, discursos de combate à corrupção têm maiores possibilidades de serem acolhidos pelas massas. A vista de elevados índices de violência urbana, os discursos de endurecimento da legislação penal tem maior propensão a serem bem recebidos pelos eleitores de forma geral. Portanto, os

Steven e ZIBLATT, Daniel. Como as democracias morrem (Tradução Renato Aguiar). Rio de Janeiro: Zahar, 2018, p. 79.

${ }^{265}$ KAKUTANI, Michiko. A Morte de Verdade (Trad. André Czarnobai, Marcela Duarte). Rio de Janeiro: Intrínseca, 2018, p. 175.

${ }^{266}$ Disponível em: <http://www.latinobarometro.org/latOnline.jsp>. Acesso em 13/09/2019.

267 STEENBERGEN, Marco R. e LODGE, Milton. "Process Matters: Cognitive Models of Candidate Evaluation". In: MACKUEN, B. Michael e RABINOWITZ, George (Orgs.). Electoral Democracy. Michigan: The University of Michigan Press, 2003, pp. 148-150.

${ }^{268}$ MARAVALL, José María. Las promesas políticas. Barcelona: Galaxia Gutemberg, 2013, p. 31. 
atores políticos têm a possibilidade de realizar um cálculo de probabilidades às consequências de suas ações, identificando qual conduta mais convém a seus objetivos. ${ }^{269}$.

Além disso, muitas vezes, o eleitor vota por um governante, mas não tem como saber, antecipadamente, quem efetivamente formará o governo. E isso não ocorre apenas nos sistemas parlamentaristas. Por exemplo, o eleitor vota em cargo majoritário para um candidato de um partido pequeno, que com poucos votos não se elege. Entretanto, o partido político deste candidato (e ele próprio) são convidados posteriormente a integrar o governo eleito, ao qual o eleitor poderia nao ter aderido à proposta apresentada no início do certame. O reverso igualmente é possível. Os eleitores do candidato A, eleito, podem não ficar satisfeitos com o convite aos candidatos $\mathrm{C}$ e D e a outros membros dos respectivos partidos, para integrar o governo em ministérios/secretarias, na medida em que os partidos destes candidatos possuem plataforma bastante distinta daquele em que o eleitor se fiou para eleger o candidato A. Portanto, a verdade é que o eleitor, mesmo quando elege seu candidato, não escolhe diretamente o "governo".

Então, por que é tão recorrente que as plataformas eleitorais que serviram de base para a escolha de um grupo político ou um candidato, sejam solenemente ignoradas já nas primeiras horas de mandato - e às vezes até mesmo antes da posse - de forma absolutamente consciente por parte dos eleitos?

Adam Przeworski aplica a Teoria dos Jogos para tentar compreender o resultado de situações estratégicas como esta. Segundo o autor, três classes de resultados podem ser identificadas: (1) resultados espontaneamente aceitos ou equilíbrios; (2) barganha ou contratos; (3) normas ${ }^{270}$.

No primeiro caso um agente não age de forma diferente, pois leva em consideração a conduta que o outro agente, com quem interage, poderia ter. Um sujeito não atravessa a rua quando o sinal não lhe favorável, ciente de que pode vir a ser atropelado. Um governante não intervém nas forças militares, receoso de que possa a vir a sofrer um golpe. Um candidato se vale de recursos não contabilizados para sua campanha sabendo que todos os outros candidatos fazem o mesmo e dificilmente serão punidos.

Na segunda hipótese o comportamento é norteado por uma terceira parte, estranha à relação originária que de alguma forma, pune os desvios de conduta atinente ao ajuste

269 PRZEWORSKI, Adam. Democracia e mercado: reformas políticas e economicas no Leste Europeu e na America Latina. Rio de Janeiro: Relume-Dumara, 1994, p. 29.

270 PRZEWORSKI, Adam. Democracia e mercado: reformas políticas e economicas no Leste Europeu e na America Latina. Rio de Janeiro: Relume-Dumara, 1994, pp. 38-43. 
realizado entre as partes. Os candidatos realizam um pacto para que na campanha eleitoral sejam discutidas apenas propostas, excluídos os ataques pessoais. Porém, só haverá efetividade se houver uma força externa que os obrigue a cumprir determinada conduta.

Por fim, na terceira hipótese, os resultados decorreriam apenas do fato de se tornarem mutuamente obrigatórios em razão do interesse pessoal da parte ou porque uma força externa impõe o cumprimento. Não há, segundo esta teoria, lógica que tenha fundamento distinto da busca estatrágica do atingimento de interesses. O pedestre deixa de atravessar a rua fora da faixa própria por receio de receber uma multa de trânsito, e não em razão do risco de sofrer um atropelamento ${ }^{271}$. O comprador de um determinado bem que já o recebeu, efetua o pagamento, sabendo que o estado-juiz poderá ingressar em seu patrimônio para que seja satisfeito o crédito do vendedor, com todos os consectários legais, multa, correção monetária, juros, honorários advocatícios, etc. As regras para o processamento do pleito eleitoral são cumpridas, porque se sabe que o descumprimento poderá acarretar na cassação da candidatura e potencial inelegibilidade futura.

Deste modo, repelem-se as teorias políticas segundo as quais a conduta resultaria de um compromisso moral ${ }^{272}$ com a ordem social, mesmo que isso não atenda a interesses particulares ou que não exista um agente para corrigir desvios de conduta. Segundo tal entendimento, o pedestre não atravessa a rua com o sinal desfavorável porque o cumprimento das normas em caráter geral beneficia a todos, o candidato, por sua vez, não se vale de recursos não contabilizados em campanha porque tem um compromisso moral com o povo ser transparente. Irreparável, nesta linha de ideias, a conclusão de Przeworski: “Como todo partido quer ganhar eleições, o acordo só prevalecerá se houver alguma força externa que o faça cumprir" 273 .

\subsection{As proposições eleitorais e a promessa do paraíso.}

A proposição eleitoral é um dos mais altos momentos de estabelecimento de vínculo entre representante e representado, pois é na apresentação de suas propostas que o

\footnotetext{
${ }^{271}$ No Brasil, o artigo 254 do Código de Trânsito prescreve a conduta do pedestre que atravessa a via em local não sinalizado para tal fim, prevendo a aplicação de multa, como infração leve, no valor de $50 \%$ referente a infrações de tal natureza.

${ }^{272}$ Kelsen lembra que embora os julgamentos morais e políticos também pretendam expressar um valor objetivo, ou seja, pressupõe uma norma objetivamente válida, a existência e o conteúdo de tal normal não pode ser aferida por meio de fatos, e baseiam-se em ideologias. KELSEN, Hans. Teoria Geral do Direito e do Estado. Tradução de Luís Carlos Borges. São Paulo: Martins Fontes, 3. Ed.,1998, p. 69.

273 PRZEWORSKI, Adam. Democracia e mercado: reformas políticas e economicas no Leste Europeu e na America Latina. Op. Cit., p. 41.
} 
candidato se vincula, se obriga com o eleitor de forma específica. Curiosamente, em pesquisa realizada antes das eleições de 2018 no Brasil, 75\% das pessoas consultadas afirmaram não acreditar no cumprimento das promessas de campanha dos candidatos ${ }^{274}$.

Propostas ou proposições eleitorais correspondem às promessas, compromissos e orientações que constam do programa partidário depositado perante a Justiça Eleitoral pelo candidato, no bojo de seu programa eleitoral de governo, bem como as demais manifestações realizadas durante o período oficial de campanha, veiculados por qualquer meio, até a data da eleição. Aqui podem ser incluídos também compromissos realizados em entrevistas, programa eleitoral gratuito, material oficial de campanha distribuído, debates, manifestações em redes sociais, etc.

As propostas não são imutáveis. Ao contrário, a diversidade multicultural e a resposta da opinião pública a propostas faz com que os candidatos rapidamente retifiquem declarações dadas, invalidando rapidamente o que seriam propostas relevantes ${ }^{275}$. Enquanto a retificação ocorre antes do escrutínio popular não há qualquer problema. Entretanto, quando o abandando à proposta ocorre após a eleição, passa-se a discutir se os cidadãos foram dolosa ou culposamente enganados, ou ainda se o recuo ocorreu por razões alheias à vontade do governante eleito.

No Brasi, a Lei Federal n ${ }^{\circ}$ 9.504/97, estabelece em seu artigo 11, inciso XII ${ }^{276}$, que no pedido de registro de candidatura, dentre outros instrumentos, devem ser apresentadas, as propostas defendidas pelo candidato a Prefeito, a Governador de Estado e a Presidente da República.

Evidentemente, os compromissos principais do candidato são aqueles que constam do programa de eleitoral de governo, apresentado à justiça eleitoral, e que deve ser difundido para que a população a ele tenha acesso e possa avaliá-lo. A apresentação das

\footnotetext{
${ }^{274}$ Pesquisa encomendada pela Confederação Nacional da Indústria ao IBOPE. “44\% dos eleitores se dizem pessimistas com eleição de 2018, diz Ibope". Portal G1. Disponível em: <https://g1.globo.com/politica/eleicoes/2018/noticia/44-dos-eleitores-se-dizem-pessimistas-com-eleicao-de2018-diz-ibope.ghtml>. Acesso em 13/03/2018.

${ }^{275}$ Por exemplo, nas eleições presidenciais brasileiras de 2018, o candidato a vice-presidente Hamilton Mourão afirmou que poderia ser elabora uma constituição por "notáveis", sem eleição de assembleia constituinte e criticou a existência do $13^{\circ}$ salário. Dias depois, o cabeça da chapa, Jair Bolsonaro, desmentiu as assertivas de Mourão, à vista de sua repercussão negativa. O então candidato Jair Bolsonaro havia apresentado proposta para aumentar o número de ministros no Supremo Tribunal Federal. Alguns dias depois, igualmente recuou da proposta.

${ }^{276}$ Incluído pela Lei Federal no 12.034 de 2009.

116
} 
propostas, em tese, deveria privilegiar a escolha das políticas públicas que serão adotadas em caso de sucesso no pleito $^{277}$.

A análise dos programas de governo permite identificar que normalmente eles apresentam proposições genéricas, irrealistas e com execução em tempo recorde, dada a ausência de implicações jurídicas acerca de seu conteúdo após a realização das eleições ${ }^{278}$. As manifestações eleitorais dos candidatos perdem-se em vagos clichês, chavões contraditórios sem dar qualquer ideia efetiva do que será realizado. São apresentadas soluções para todos os problemas relacionados à política estatal: educação, saúde, desemprego, segurança pública, economia, meio ambiente, agricultura e pesca, indústria e comércio, tecnologia, esportes, previdência social, políticas de integração de deficientes e idosos, justiça, política e comércio exterior, etc.

Um exemplo simples é a assertiva de que "será retomado o investimento público". Não se discrimina a origem da receita, o destino da despesa, o quanto isso depende de outros órgãos, mas se transmite um juízo de realização política futura. $\mathrm{Na}$ era da instantaneidade, como lembra Bauman, tutela-se a bonificação sem que se tenha que sofrer as consequências e responsabilidades decorrentes das escolhas realizadas ${ }^{279}$.

Não raro as condutas políticas negativas são bem delineadas na legislação, vale dizer, tudo aquilo que não deve caracterizar a conduta do governante. Entretanto, são raríssimas as indicações efetivas de "conformação jurídica do governo, quando legitimado pelo voto popular, a dirigir o país e as instituições públicas, no interesse da sociedade" ${ }^{280}$.

É natural que os partidos sejam livres para se manifestar e apresentar suas impressões sobre toda sorte de questão levantada no debate eleitoral, o que deve ser melhor delineado é exatamente a instrumentalização das propostas realizadas, que decorrem especificamente do programa eleitoral de governo apresentado.

277 “O mínimo que se espera de um postulante à Presidência da República é que ele saiba o que pretende fazer ao assumir o cargo e deixar isso claro a seus eleitores, permitindo que estes possam escolher estadistas, e não personalidades; que possam eleger com base em programas, e não em pessoas". CONTI, José Maurício. Levando o Direito Financeiro a Sério. São Paulo: Blucher, 2016, p. 68.

278 “(...) políticos que desejam lograr-se vencedores em eleições, em vez defenderem de forma coerente suas plataformas políticas, acabam se redendendo a reproduzir à la carte os anseios de seus futuros eleitores, preparando, com o auxílio dos meios digitais, campanhas com inúmeros coloridos, nem sempre efetivamente compatíveis com aquilo que ele irá fazer no futuro governo, mas que são direcionados para os variados públicos-alvo". NOHARA, Irene Patrícia. "Desafios da ciberdemocracia diante do fenômeno das fake news: regulação estatal em face dos perigos da desinformação". In: RAIZ, Diogo (coord.) FAKE NEWS: a conexão entre a desinformação e o direito. São Paulo: Thomson Reuters Brasil, 2018, p. 82.

${ }^{279}$ BAUMAN, Zygmunt. Modernidade Líquida. Op. Cit., p. 148.

280 BUCCI, Maria Paula Dallari. Fundamentos para uma Teoria Jurídica das Políticas Públicas. São Paulo: Saraiva, 2013, p. 62. 
O projeto de Lei do Senado Federal $n^{\circ}$ 229/2009, denominado Lei de Qualidade Fiscal, com vistas a substituir a Lei Federal n 4.320 de 1964, que regula os orçamentos públicos, previa no artigo $6^{\circ}, \S 2^{\circ}$, a seguinte disposição “o PPA [Plano Plurianual] considerará o plano de governo do candidato eleito Chefe do Poder executivo, devendo todos os candidatos registrar o respectivo plano de governo na Justiça Eleitoral em até dois meses antes da data do pleito eleitoral, em primeiro e único turno". Embora ainda se pudesse discutir a real efetividade da referida proposta no que tange à ausência de penalidade por eventual descumprimento, é certo que a redação tem a nítida intenção de entrelaçar o Plano Plurianual e as propostas realizadas em campanha, trazendo normatividade ao conteúdo das propostas. Lamentavelmente, a disposição não foi aprovada pelo Senado Federal ${ }^{281}$.

Para que a população possa compreender os programas de governo, devem ser apresentados objetivos claros. Deve-se exigir que o candidato que propõe indique não apenas o que pretende implementar, mas em qual prazo e valendo-se de quais meios. A valorização do processo eleitoral e da democracia, por conseguinte, parece não mais compactuar com as proposições genéricas ou de números desvinculados de qualquer estudo ou viabilidade financeira.

O tempo é um fator relevante para a análise de políticas públicas. Aliás, o fator tempo, especialmente em democracias mais jovens, impõe que o tempo político atue de forma pragmática alinhando o ciclo de políticas públicas com o calendário eleitoral.

Um problema que se coloca na exigência de que o candidato apresente objetivos minuciosos reside em como exigir que o político que sequer foi eleito e, portanto, não conhece amiúde a prática da administração pública, forneça propostas pormenorizadas. Existe certo dilema em exigir que o candidato apresente propostas objetivas ao mesmo tempo em que muitos candidatos não têm conhecimento específico para a formulação de propostas realistas.

Uma primeira resposta é bastante simples. Se o candidato não tem condições de saber o que será possível implementar, que não realize promessas. Limite-se a demagogia e o descompromisso. Neste caso caberia ao candidato apresentar-se como a melhor escolha, limitando-se a dizer que, uma vez eleito, avaliaria as medidas a tomar. Como tal hipótese é um tanto quanto irrealista, uma segunda resposta parte do princípio de que aquele que pretende administrar um país, estado ou município, por menor que seja, deve

${ }^{281}$ Atualmente referido projeto encontra-se em análise na Câmara dos Deputados, desde 21/06/2016. 118 
minimamente, com o auxílio de pessoas que potencialmente possam formar sua equipe e de seu partido político, dar-se ao trabalho de analisar o orçamento aprovado para o exercício seguinte e formular suas propostas eleitorais. Portanto, é dever do candidato preparar-se para o cargo, no que inclui a efetiva avaliação e escolha de suas propostas eleitorais.

Isso naturalmente não tornaria as propostas do candidato imutáveis após a eleição, mas prestigiaria maior accountability, na medida em que as propostas seriam mais claras. Da mesma forma, as próprias justificativas para descumprimento igualmente poderiam ter restado evidenciadas. Por exemplo, o cancelamento da transferência de uma verba federal que estava reservada ao município justificaria a não realização de determinada obra, vinculada a tal recebimento.

Outro questionamento reside em saber se o candidato poderia, durante o próprio período de campanha eleitoral reformular suas propostas. A resposta deve ser afirmativa. Nada impede que durante a campanha o candidato module suas propostas, o que inclusive é natural, na medida em que passa a ter contato com mais profissionais e eleitores.

Isso não é o mesmo do que dar sentido distinto à proposta após a realização das eleições. Na campanha presidencial norte-americana de 2016 o Presidente Donald Trump trouxe como principal proposta para a segurança nacional a construção de um muro na fronteira com o México, cujo custo seria "pago" pelo México. Entretanto, já no governo, negou que tivesse sido realizada tal promessa, afirmando que a interpretação correta do que disse era no sentido de que o México pagaria, mas não em pecúnia, e sim estariam em relação ao conteúdo de acordos comerciais celebrado entre Estados Unidos, México e Canadá ${ }^{282}$.

\subsection{Natureza jurídica das proposições eleitorais.}

Os programas eleitorais possuem natureza híbrida apresentando ao mesmo tempo elementos do âmbito do direito e da esfera política. Esse caráter compósito, entretanto, não é equitativo. Conforme analisaremos mais adiante, são raros os sistemas que conferem alguma relevância jurídica, ainda que mínima, às propostas eleitorais, podendo-se afirmar que natureza jurídica das propostas eleitorais é preponderantemente política.

\footnotetext{
282 "Trump says he 'never meant Mexico would write a check' for the wall" Disponível em: $<$ https://www.cnbc.com/2019/01/10/trump-says-mexico-is-not-going-to-write-a-check-for-the-wallcontradicting-campaign-pledge.html>. Acesso em 14/02/2019.
} 
Aos auspícios do regime parlamentarista italiano, Alberto Russo asseverava que o mandato possuía dupla função impositiva em relação ao governo. A primeira era o dever de implementar os compromissos perante o país, o que ele denomina de eficácia positiva. Um segundo aspecto correspondia à chamada eficácia negativa, que representava o dever de não aprovar qualquer medida de qualificação que não tenha sido submetida anteriormente ao eleitorado.

Deste modo, dado o caráter impositivo do "Manifesto Eleitoral", no caso da conduta do governo que optasse por orientar suas ações em direção a objetivos distintos dos representados no compromisso, deveria ocorrer a dissolução antecipada do parlamento, para que o eleitorado fosse novamente chamado a escolher seus representantes e por via reflexa, as diretrizes a serem seguidas ${ }^{283}$. Aqui Russo se refere ao programa aprovado pelo parlamento e não as diretrizes de campanha eleitoral. Conforme veremos no item seguinte, trata-se da distinção entre o programa de governo, a que faz referência Russo e segundo ele teria caráter cogente, e ao programa eleitoral de governo, que é o cerne da nossa pesquisa.

\subsection{As modalidades de proposições eleitorais.}

Programa eleitoral ou programa de campanha eleitoral não se confunde com programa de governo. González aponta,em primeiro lugar, que o programa eleitoral é uma figura incerta, sob a perspectiva jurídico-constitucional, pertencendo exclusivamente ao mundo político e não ao mundo do direito, enquanto o programa de governo tem maior reconhecimento jurídico. Em segundo lugar, os destinatários também são distintos. O programa eleitoral tem por foco a cidadania e os eleitores, ao passo que no programa de governo os destinatários são os deputados e grupos parlamentares. Em terceiro lugar o programa eleitoral é formulado sem a necessidade de uma base real de implementação, prévio às eleições, enquanto o programa de governo encontra-se em terreno institucional, sem o compromisso de "tener que convencer para ganar" 284.

${ }^{283}$ RUSSO, Alberto. Programma di Governo e Regime Parlamentar. Milão: Giuffré Editore, 1984, pp. 175-176.

284 "El programa electoral constituye, pues, la base del programa de gobierno, el compromiso poítico asumido ante los electores y que se espera sea sancionado parlamentariamente en el acto de investidura. Como quisera que sea, hay que reconocer que, en ocasiones, puede producirse una cierta modulación o rectificación del programa electoral en su traslación al programa de gobierno, debida no tanto a la necesidad de acercarse a otros grupos políticos cuyo apoyo resulte fundamental, cuanto al conocimento de la auténtica situación, el la que se encuentra el país" GONZÁLEZ, María Holgado. El Programa de Gobierno y sus Sistemas de Control. Valencia: Tirant Lo Blanch, 2008, pp. 37-38. 
Como regra geral, o programa de governo tem por pressuposto o programa eleitoral, representado pela força política que majoritariamente foi escolhida pelos eleitores, ou seja, o programa de governo teria que se basear nas propostas eleitorais apresentadas à cidadania e que resultaram na consagração do grupo vencedor. A pesquisa de González tem por horizonte o regime parlamentarista, em que o programa de governo é submetido à aprovação do parlamento, após as eleições"285. Nos países de regime presidencialista, como regra não há um programa de governo a ser submetido ao parlamento. Isso não quer dizer que não exista um dever de orientar-se em direção a um “programa”, como lembra Bruno Lorencini ao citar o artigo 74, I, da Constituição Federal Brasileira, que determina que todos os poderes manterão órgãos de controle interno, de forma integrada, com o escopo de "avaliar o cumprimento das metas previstas no plano plurianual, a execução dos programas de governo e dos orçamentos da União"286.

A vista do objetivo da nossa pesquisa e por razões didáticas optamos por empregar a denominação programa eleitoral de governo, em vez de apenas programa eleitoral. A menção a programa eleitoral incute a ideia de que ele se esgota com as eleições. Não poderíamos também entender os termos como sinônimos pelas razões já expostas até porque, após a eleição, a elaboração de plano está sujeita a outros elementos políticos e fáticos. O programa é eleitoral, porque ainda se está na fase de sujeição ao escrutínio popular, mas é um plano que estará vinculado ao governo, que gerará efeitos para além da eleição e ingressará na esfera governamental. O espectro de análise não está apenas na eleição, mas na conexão entre o momento eleitoral e o momento da investidura.

Conforme supra delimitado, o recorte temporal em que tomamos as proposições eleitorais inicia-se no registro de candidatura e termina na data da eleição, abrangendo inicialmente o programa eleitoral de governo apresentado à Justiça Eleitoral, complementado por todas as manifestações posteriores do candidato em que este realiza expressamente um determinado compromisso.

Podemos classificar as propostas eleitorais, quanto à sua formulação, em "propostas legais" e "propostas criminalizadas". Quanto à possibilidade de concretização as propostas legais podem ser classificadas em "legais inexequíveis" e "legais exequíveis". Por fim, as proposições legais exequíveis, de seu turno, podem ser divididas, em relação à

${ }^{285}$ GONZÁLEZ, María Holgado. El Programa de Gobierno y sus Sistemas de Control. Valencia: Tirant Lo Blanch, 2008, p. 33.

${ }^{286}$ LORENCINI, Bruno. Democracia Qualificada e Responsabilidade Política. São Paulo: LiberArs, 2018, p. 267. 
possibilidade de aferição, em "propostas objetivas" e "propostas subjetivas". Por fim, estas últimas podem ser decompostas em "subjetivas meramente programáticas" e "subjetivas propriamente ditas".

A primeira classificação das propostas eleitorais, portanto, consiste em dividí-las em "legais" ou "criminalizadas". Esta categorização corresponde às proposições que atingem a idoneidade do próprio procedimento eleitoral e consistem em uma promessa individualizada, seja a uma pessoa ou a um grupo, no sentido de que caso obtida a votação, será fornecido um benefício pessoal - não institucional - ao promissário ${ }^{287}$. Por exemplo, o delito previsto no artigo 300 do Código Eleitoral Brasileiro que pune a conduta de "dar, oferecer, prometer, solicitar ou receber, para si ou para outrem, dinheiro, dádiva, ou qualquer outra vantagem, para obter ou dar voto e para conseguir ou prometer abstenção, ainda que a oferta não seja aceita". Na Espanha, o artigo 146 da Ley Orgánica n 5/1985 torna tipica a mesma conduta, prevendo pena de prisão.

As "propostas legais" são aquelas que respeitam as regras do pleito eleitoral. Importante aqui anotar que a legalidade não recai sobre o objeto da proposta, razão pela qual não falamos aqui de inconstitucionalidade ou ilegalidade do conteúdo da promessa. A legalidade, então, reside apenas em formular uma proposta sem incidir em uma afronta às normas do certame eleitoral. Uma proposta realizada no dia da própria eleição representa uma proposta ilegal no Brasil, a vista do término do período de campanha eleitoral nas quarenta e oito horas que antecedem ao pleito $^{288}$.

A regulamentação da propaganda eleitoral tem como finalidade precípua a preservação de condições de igualdade para os disputantes. No Brasil, a Lei Federal $\mathrm{n}^{\circ}$ 13.165/2015 apresenta elementos de "controle formal", como o período de campanha, entre 15 de agosto e o dia anterior à eleição, a necessidade de utilização da língua portuguesa e a divisão do tempo de televisão. O Código Eleitoral (Lei n 4.737/1965) e a Lei das Eleições (Lei n 9.504/1997) trazem instrumentos de "controle material" que repousa sobre o conteúdo da propaganda, como vedação à instigação à desobediência civil, ofensas à honra de outros candidatos, oferecimento de qualquer vantagem, etc.

O artigo 323 do Código Eleitoral Brasileito prevê como crime, sujeito a apena de detenção de dois meses a um ano e pagamento de multa a conduta de divulgar, na

\footnotetext{
${ }^{287}$ Nos Estados Unidos, o $\$ 599$ do U.S. Code, no Título 18, prevê a pena de multa ou prisão de até 1 ano para o candidato que promete, direta ou indiretamente, a nomeação ou o uso de influência para nomeação de qualquer pessoa para emprego público ou privado, com o escopo de obter apoio a sua candidatura.

${ }^{288}$ Art. 240, parágrafo único, do Código Eleitoral Brasileiro (Lei Federal n 4.737/1965). 
propaganda, fatos que sabe inverídicos, em relação a partidos ou candidatos e capazes de exercerem influência perante o eleitorado. Pretende-se impedir que a formação da opinião do eleitoral seja formada a partir de informações inverídicas.

Nota-se que a legislação pune a propaganda de fatos inverídicos relacionados aos sujeitos da disputa eleitoral, mas não pune a propaganda de fatos sabidamente falsos, relacionados à possibilidade jurídica de suas propostas. $\mathrm{O}$ legislador opta aqui pelo amplo debate democrático, ainda que possam ser realizadas propostas que sequer se inserem na esfera de competência do candidato. Por exemplo, um candidato ao governo de estado que proponha a pena de morte nesta unidade federativa. É cediço que tal matéria constitui cláusula pétrea constitucional e desboarda totalmente da esfera de competência do ente federado. Contudo, inexiste qualquer instrumento que impeça o candidato de realizar, mesmo ciente da impossibilidade, promessas desta natureza, visando agradar ao corpo eleitoral a partir de uma estratégia de marketing.

Por isso, as propostas legais podem ser classificadas quanto à possibilidade de concretização em "legal executável" e "legal inexequível". A inexiquibilidade pode ser fruto de impossibilidade física, como o candidato que promete a construção de uma ponte ligando Brasil à Espanha, ou impossibilidade jurídica, como na hipótese de a proposta formulada escapar da competência legal do proponente.

Em seguida, as proposições eleitorais ou propostas de campanha legais exequíveis, podem ser classificadas quanto à possibilidade de aferição de seu cumprimento em "legais objetivas" e "legais subjetivas", sendo que aquelas não dependem de qualquer aferição valorativa para análise quanto a seu cumprimento, enquanto estas demandam discussão sobre se houve ou não cumprimento. Note-se que a aferição valorativa não se confunde com as hipóteses excludentes de exigibilidade, como veremos mais adiante.

Em relação às propostas "legais objetivas", que infelizmente costumam ser bastante raras entre as propostas eleitorais, podemos citar o exemplo observado na eleição para a prefeitura do Município de São Paulo em 2016, em que o então candidato João Doria, prometeu aumentar a velocidade permitida das marginais ${ }^{289}$. Após a eleição a medida foi efetivamente cumprida, com o "Programa Marginal Segura". Sem entrar no mérito de tal questão, o fato é que o candidato foi eleito, e inclusive muitos de seus eleitores

${ }^{289}$ Tal questão foi objeto de intenso debate eleitoral entre aqueles que sustentavam que os limites estavam muito baixos, piorando a fluidez do trânsito e aqueles que advertiam que a liberação de velocidades mais elevadas conduziriam a mais acidentes, mortes e, por conseguinte, também à piora do trânsito. Disponível em: https://www.nossasaopaulo.org.br/portal/arquivos/metas-programa-doria.pdf. Acesso em 25/09/2018. 
sustentavam que uma das razões principais da escolha era a promessa relacionada ao aumento da velocidade nas marginais. Após a eleição o prefeito implementou a medida prometida. Outro exemplo de proposta objetiva é extraído do programa eleitoral de governo do Partido Podemos, para as eleições presidenciais espanholas de 2015, em que na área de educação, o programa aponta diretamente o número máximo de alunos em sala de aula para cada grau de ensino ${ }^{290}$. Na campanha presidencial brasileira de 2018 , o então candidato Jair Bolsonaro prometeu, uma vez eleito, reduzir o número de ministérios de vinte e nove para quinze ${ }^{291}$. A medida não foi cumprida, tendo o presidente iniciado seu governo com vinte e dois ministérios.

Observa-se que, nestas hipóteses, havia somente duas possibilidades: ou a Administração cumpria a promessa ou não a realizava, já que a prática do ato não demandava qualquer condição externa ou o concurso de outro órgão, como o Poder Legislativo. Trata-se de proposições objetivas, que independem de juízo de valor. No primeiro caso, sob competência exclusiva do Prefeito Municipal, aumentava-se o limite de velocidade ou não. Em relação à proposta do Podemos, caso tivesse vencido o pleito, haveria o ônus de atender às especificações de número de alunos por sala, implicando no cumprimendo da promessa ou descumpri-la e, eventualmente alegar impossibilidade por alguma razão, como redução orçamentária ou realização de estudo que sustentasse a eficácia do ensino em salas com mais alunos.

Imaginemos, porém, que nestes casos se tratassem de matérias sobre a qual recaísse reserva de lei, de modo que não fosse possível ao governante implementar, de pronto, a promessa. Neste caso, a aferição acerca do cumprimento da medida seria verificada mediante o envio do projeto de lei para a casa legislativa correspondente. E não se diga que por se tratar de matéria de competência legislativa tocaria exclusivamente ao Poder Legislativo, pois o líder do Poder Executivo é protagonista no processo de criação de normas, havendo um sentido político em sua participação neste processo. Diversos são os fatos que demonstram essa atuação. O Chefe do Poder Executivo é o condutor da política dentro de sua esfera de poder e ao mesmo tempo chefe da Administração Pública. É ele

290 “107. Disminuiremos la ratio de alumnado por aula en los centros públicos, estableciendo un máximo de 20 en Infantil, 23 en Primaria, 25 en Secundaria, 30 en Bachillerato, 15 en Formación Profesional Básica y 25 en los ciclos formativos de grado medio y superior". Disponível em: <https://podemos.info/wpcontent/uploads/2015/05/programa_marco_podemos.pdf>. Acesso em 25/09/2018.

291 Disponível em:

https://www.em.com.br/app/noticia/politica/2018/10/05/interna_politica,994655/bolsonaro-diz-que-se-eleitogoverno-tera-no-maximo-15-ministerios.shtml>. Acesso em 27/02/2019. 
também quem detém a iniciativa financeira do uso dos meios públicos, cabendo-lhe ainda a coordenação da atividade de intervenção na economia ${ }^{292}$.

Em algumas oportunidades o candidato a um determinado cargo eletivo afirma que cumprirá o mandato integralmente, asseverando que não deixará o cargo antes do termo final para concorrer à outra cadeira. Trata-se, pois, de uma proposta classificada como "legal objetiva".

Tal situação aconteceu em setembro de 2004 quando José Serra, então candidato à Prefeitura do Município de São Paulo assinou documento se comprometendo a cumprir o mandato na íntegra. João Dória, durante a campanha para a Prefeitura do Município de São Paulo, em setembro de 2016, assinou documento afirmando que não deixaria a prefeitura antes do termo final. Contudo, ambos os alcaides deixaram a prefeitura antes do término do mandato para concorrer ao cargo de Governador do Estado, José Serra $2006^{293}$ e João Doria em 2018 294 , ambos eleitos, sendo que José Serra venceu no Município de São Paulo (53\% dos votos) e João Doria no governo estadual (41,90\%). Diante disso, poderia se questionar se os munícipes paulistanos teriam anuído tacitamente com a quebra da promessa de José Serra ao lhe conferir sucesso na candidatura eleitoral, embora discordado em relação a João Doria. A nosso ver a resposta é negativa, na medida em que muitas vezes o voto se dá por exclusão, ou seja, vota-se em um candidato do qual não se considera o ideal, mas para evitar que outros assumam o poder. Isso não se confunde com a presunção de que os munícipes não teriam se importado com a quebra do compromisso.

De outro lado, as "propostas legais subjetivas" são aquelas cuja aferição demandará análise concreta de circunstâncias para verificação de cumprimento de seu objeto. Elas podem ser divididas em "subjetivas meramente programáticas", que não são passíveis de análise quanto a seu cumprimento, uma vez que enunciam de forma bastante genérica uma ideia, inviabilizando sua aferição e "subjetivas propriamente ditas", em que embora as propostas sejam claras e individualizadas, a análise quanto ao cumprimento demanda esforço interpretativo e cotejamento de dados.

292 BUCCI, Maria Paula Dallari. Fundamentos para uma Teoria Jurídica das Políticas Públicas. São Paulo: Saraiva, 2013, p. 105-106.

293 “'Não fui ao cartório', diz Serra sobre promessa de campanha em 2004”. Estadão, 20/03/2012. Disponível em: <http://politica.estadao.com.br/noticias/geral,nao-fui-ao-cartorio-diz-serra-sobre-promessade-campanha-em-2004,851093>. Acesso em 22/03/2018.

294 "Contrariando promessa, João Doria se lança ao governo de SP" Disponível em: $<$ https://catracalivre.com.br/geral/cidadania/indicacao/contrariando-promessa-joao-doria-se-lanca-aogoverno-de-sp/>. Acesso em 22/03/2018. 
Sobre as "propostas subjetivas meramente programáticas", citamos novamente o programa eleitoral de governo do Partido Podemos, para as eleições presidenciais espanholas de 2015, que tratando do tema meio ambiente e transporte, afirmava que impulsionaria o uso de meios de transporte alternativos ao carro particular ${ }^{295}$. Trata-se de uma enunciação genérica, absolutamente impossível de aferição, na medida em que não foram fixados parâmetros. Por exemplo, não foi afirmado que se implementaria ou aumentaria rodízio de veículos, que haveria nova taxação para utilização de veículo ou em que localidades o transporte público sofreria melhorias, com aumento de linhas, construção de estações, etc. Bem por isso, mesmo que o governante implemente algumas dessas medidas, o que para muitos especialistas da área poderia representar um atendimento da expectativa, a verdade é que como não foi estabelecido um parâmetro, por menor que fosse, a aferição restaria prejudicada.

No Programa do PSDB para o pleito municipal de São Paulo no ano de 2016, em relação à educação municipal, afirmou-se que uma das metas era "ampliar o acesso à educação integral". Diferentemente da proposta realizada pelo partido espanhol, que de forma minudente especificou o número máximo de alunos por sala de aula, no programa do partido brasileiro não há indicadores de número ou percentual de majoração das vagas em tempo integral, o que impediria sua aferição. Portanto, a proposta realizada pelo PSDB pode ser classificada como "subjetiva meramente programática".

Questão interessante reside em saber se, uma vez implementadas as medidas, poderia o governante retroceder e cancelá-las ou modulá-las. Evidente que sim, mas não se forma irrestrita. Não faria sentido engessar a administração até o término do mandato. $\mathrm{O}$ que nos parece desejável é a existência de mecanismos que o obriguem a orientar-se no sentido das propostas. No exemplo da redução da velocidade nas marginais, após a implementação e cumprimento da medida, o governante poderia ter se convencido, à luz de estudos, de que a majoração da velocidade aumentou o número de acidentes e óbitos, gerando assim uma menor fluidez do trânsito, em oposição ao objetivo inicialmente buscado com a medida. De outro lado, em relação ao número de alunos por sala, também poderia ser admitida uma mudança, desde que, por exemplo, restasse comprovado que o nível de ensino e desempenho subiu nas escolas em que não houve a redução do número de

295 "84. Se impulsará el uso de medios de transporte alternativos al coche particular: transporte público, ferrocarril (también incrementando la cuota modal de transporte de mercancías hasta alcanzar la media europea), vehículos eléctricos y bicicleta". Disponível em: <https://podemos.info/wpcontent/uploads/2015/05/programa_marco_podemos.pdf>. Seção 2, item 7.4. Acesso em 25/09/2018. 
alunos ou que novos estudos demonstrassem a desnecessidade de redução do número de alunos para melhoria de desempenho.

Por fim, as propostas podem se distinguir quanto à sua mutabilidade em “inalteradas" ou "alteradas". A proposta "inalterada" é aquela que, desde a sua apresentação, após o início da campanha se manteve íntegra e foi sempre defendida pelo candidato em suas manifestações até a data de eleição. A proposta "alterada" consiste na proposição que sofre alteração, total ou parcial, após formulação inicial durante o processo de campanha eleitoral. Não é incomum que no bojo das discussões eleitorais, e, sobretudo diante da repercussão de algumas propostas, existam retificações por parte dos candidatos, em especial quando em eleições majoritárias se atinge o segundo turno eleitoral.

A classificação das propostas ganha relevância diante do objetivo de avaliação do cumprimento dos compromissos e da análise quanto à sua implementação por meio de tutela jurisdicional.

\subsection{Da falta de controle jurídico sobre as propostas eleitorais e a busca da eficiência.}

O âmbito das propostas eleitorais, sob o manto da liberdade democrática é totalmente aberto no que se refere à irrelevância da exequibilidade das propostas. Em outras palavras, o sistema jurídico admite que propostas sejam realizadas em uma direção e o governo se paute por diretrizes distintas já nos primeiros dias de governo. Inexiste, portanto, remédio jurídico contra a demagogia político-eleitoral, havendo uma verdadeira condescendência dos regimes democráticos com a figura do "estelionato eleitoral"296.

Mauricio Villegas, pretendendo compreender referida questão, aponta que as propostas e promessas políticas orientam-se para o futuro, daí certa tolerância com que apenas parte delas se torne realidade. De outro lado, o direito tem por horizonte o presente, e pretende regrá-lo por meio de procedimentos claros e anteriormente previstos ${ }^{297}$. Como buscar, então, uma aproximação entre a política e o direito?

O critério comparativo adotado por Sartori, que em vez de conceituar a democracia preferia identificar se ela era ou não mais desejável que outros regimes, coloca-nos diante

296 BRANCO, Rilke Rithcliff Pierre. "Responsabilidades Político-Eleitorais, o Impeachment, a Improbidade e a Demagogia”. Revista Temas Socio-Jurídicos. Bucamaranga, Colombia, v. 36, ed. 73, julhodezembro, 2017, p. 145,

297 VILLEGAS, Mauricio Garcia. "Constitucionalismo Aspiracional: Derecho, Democracia y Cambio Social en América Latina”. Revista Análisis Politico. Bogota, v. 25, ed. 75, maio-agosto, 2012, p. 90. 
da seguinte pergunta: é mais desejável um regime em que as promessas formuladas em campanha eleitoral sejam cumpridas em comparação com um sistema em que elas podem ser livremente descumpridas ao talante do eleito? Ou ainda: é mais desejável um sistema em que o governante oriente suas políticas públicas de acordo com os compromissos de campanha ou um sistema em que o governante não sofra qualquer consequência por ignorar por completo seus compromissos eleitorais ${ }^{298}$

Conforme observado nos itens anteriores, atualmente os partidos utilizam alto grau de pesquisa de opinião dos eleitores acerca dos mais diferentes temas e posicionamentos. A partir de então, em uma campanha eleitoral toda a propaganda e o programa eleitoral de governo é realizada com base em tais informações. Os partidos políticos buscarão identificar exatamente o que o eleitor gostaria de ouvir para formar seu plano de governo e fazer proposições eleitorais, justamente para receberem os votos necessários para assumirem o poder. Cria-se, portanto, um vínculo representativo, mas restam os representantes juridicamente desobrigados de cumprimento ${ }^{299}$.

Não se ignora que muitos eleitores fazem suas escolhas apenas com base na agremiação política ou mesmo por conta da pessoa física do candidato. Contudo, para nós não há dúvidas de que no momento da apresentação de específicos compromissos, o candidato transforma-se em proponente, ao qual os eleitores, na qualidade de oblatos, aderem a suas propostas ao garantir-lhe o voto. Conduzir-se de acordo com o programa eleitoral de governo e com as propostas representa uma conduta ativa em relação à manifestação popular ${ }^{300}$.

A população em geral não tem conhecimento sobre a maior parte dos temas ligados à administração e à política. Por isso, cabe ao representante tomar tais decisões. Entretanto, ainda que os cidadãos não conheçam propriamente questões como orçamento público, legislação e procedimentos, têm a legítima expectativa de que o governante elegerá os meios para atendimento do melhor interesse da coletividade, que foi plasmado em sua

19.

${ }^{298}$ SARTORI, Giovanni. A Teoria da Democracia Revisitada. São Paulo: Ática, 2 Ed., 1994, pp. 18-

299 BERRINGTON, Hugh. "Dialogue of the deaf? The Élite and the Electorate in Mid-Century Britain”. In: KAVANAGH, Dennis (org). Electoral Politics. Oxford: Clarendon Press, 1992, p. 93.

300 “(...) o governo será capaz de produzir poder social, desde que tenha êxito em canalizar demandas da sociedade e alcançar formas de organização que, a partir da identificação de pontos de consenso entre os interesses em disputa, logrem evoluir para iniciativas complexas de solução dos problemas em pauta. Em complemento, espera-se do governo capacidade de identificar pontos de dissenso, estruturando o processo de mediação do diálogo social, por meio do qual se ajustem expectativas e se componham as diferentes alternativas, reduzindo-se em parte as frustrações em relação às demandas não atendidas”. BUCCI, Maria Paula Dallari. Fundamentos para uma Teoria Jurídica das Políticas Públicas. São Paulo: Saraiva, 2013, p. 62. 
campanha eleitoral, na qual indicou o que, a seu juízo, bem como de seu partido e coligação, representariam a melhor tutela dos interesses da coletividade.

Nos contratos privados, ressalvados alguns temperamentos como a tutela concedida aos consumidores e outras partes hipossuficientes, não é dado ao contratante escusar-se ao cumprimento das obrigações, sob o argumento de que desconhecia o objeto contratual ou mesmo a lei, valendo o adágio pacta sunt servanda. Nesta linha de raciocínio, também não deveria ser concedido ao candidato a cargo executivo que realizasse compromissos sem minimamente ter por horizonte a realidade, sem que houvesse consequências jurídicas para tanto em caso de inobservância. Do outro lado do polo obrigacional, da mesma forma, o eventual desinteresse de parcela da cidadania nas propostas eleitorais não pode ser igualmente tomado como escusa para se rejeitar um sistema que tenha natureza cogente em relação às propostas. $\mathrm{O}$ processo democrático impõe que, periodicamente, os cidadãos celebrem esses "contratos" atípicos, elegendo governantes. Assim, na verdade, se permanecermos no paralelo com o Direito Civil, o contrato seria impositivo, não tendo a cidadania a opção de não celebrar o contrato, mas ficando a ela reservada a opção de escolha do candidato e de sua plataforma de governo.

Então por que é tão recorrente que as plataformas eleitorais que serviram de base para a escolha de um grupo político ou um candidato, sejam ignoradas de forma protocolar e com absoluta consciência por parte dos eleitos?

Chama à atenção o quanto realmente o sistema democrático parece contentar-se com as eleições como ápice do combate político, mas imediatamente o coloca em uma zona de liberdade apta a negar ontologicamente todo o processo atingido até ali $^{301}$.

A existência de um controle prévio sobre as propostas de campanha eleitoral seja sobre o aspecto de sua constitucionalidade ou legalidade, como em relação a sua exequibilidade fática não pode ser admitida. Em primeiro lugar porque contraria o direito individual à livre manifestação, tutelado em sede constitucional. Além disso, engessaria indevidamente a atividade política e traria ainda maior judicialização ao tema, antes do pleito eleitoral. Outro inconveniente, ainda que se tratasse de declarar a

301 "Nos processos políticos-eleitorais, a falta dos denodos morais, individuais ou partidários, as promessas, as doações e os objetos frutos de campanhas demagógicas, que traem a confiança do eleitorado nos candidatos, sobretudo após a ocupação de postos no Poder Público, não recebem uma proteção jurídica séria com a correspondente penalidade à altura. O desdém pela ética do "jogo político", as firulas e os sofismas verbais dos participantes dos pleitos eleitorais não disfarçam o afã verdadeiro de muitos que objetivam apenas obter vantagens materiais pessoais, em detrimento da probidade e da incolumidade do Estado de Direito Constitucional na devida condução da res publica". BRANCO, Rilke Rithcliff Pierre. "Responsabilidades Político-Eleitorais, o Impeachment, a Improbidade e a Demagogia". Op. Cit., p. 146. 
inconstitucionalidade prévia de propostas, seria a impossibilidade de rapidamente resolver conflitos desta natureza, o que tornaria ainda mais inócuo o controle prévio.

Ainda que admitamos o controle preliminar, ou seja, anterior à eleição, é certo que alguns inconvenientes podem efetivamente surgir quando um candidato formula uma proposta de flagrante inconstitucionalidade, inclusive ciente de tal situação. Imaginemos um município que esteja sofrendo com o crescimento do índice de desemprego, agregado a alarmantes índices de violência, no qual um candidato a prefeito afirma em sua campanha que instituirá, legalmente, o imposto municipal sobre grandes fortunas, como instrumento para a retomada do desenvolvimento econômico e investimento em segurança. Embora este tipo de proposta seja de candente inconstitucionalidade ${ }^{302}$, não haveria como realizar um controle prévio. O sistema jurídico carece de um mecanismo que, durante a evolução do governo, evidencie para os eleitores do candidato eleito e para a população como um todo, que se tratava de uma medida inconstitucional e que restou, portanto, descumprida. É certo que no exemplo dado, mesmo a despeito da inconstitucionalidade, não se poderia ignorar que a mensagem captada pelos eleitores e pelo eleito, implica em uma maior inclinação ao incremento arrecadatório do município.

No Brasil, no caso de eleições proporcionais, o mandato pertence ao partido político, de modo que se o parlamentar uma vez eleito filiar-se a outra agremiação, perderá o mandato se não for reconhecida justa causa para a sua desfiliação, nos termos do artigo 22-A da Lei dos Partidos Políticos (Lei Federal $n^{\circ}$ 9.096/1995). Entre as causas que autorizariam a desfiliação encontra-se no parágrafo único, inciso I, a "mudança substancial ou desvio reiterado do programa partidário. O pressuposto da norma é tutelar não apenas a figura do partido, mas o seu "programa", vale dizer suas diretrizes, suas propostas, como elemento que é relevante e que deve ser respeitado, sob pena de o parlamentar, eleito sob tais bandeiras e diretrizes, restar autorizado a migrar para outra legenda. A reflexão que emerge sustenta-se no fato de que se o candidato eleito deve observar o programa partidário, sob pena de perda do mandato, a fortiori deveria se orientar no sentido de observar o programa submetido ao titular da soberania, o povo.

Em síntese, a reflexão trazida implica em questionar se a formulação de propostas consta apenas como um instrumento acessório e irrelevante de uma democracia procedimental eleitoral que objetiva apenas afastar a tirania ou se, para além do rito de

\footnotetext{
302 O artigo 153, VII, da Constituição Federal Brasileiro reserva competência exclusiva à União, nos termos de lei complementar, para a eventual criação de imposto sobre grandes fortunas. 
escolha de um novo governante, deve visar também a promoção do autogoverno, por meio do constante atendimento das opções do povo em relação ao conteúdo do governo, conferindo estabilidade ao sistema democrático.

\subsection{As proposições eleitorais no direito comparado.}

No Brasil o pedido de registro de candidaturas para os órgãos de chefia do Poder Executivo devem ser instruídos com propostas defendidas pelo candidato a Prefeito, a Governador de Estado e a Presidente da República. A determinação, porém, não encontra status constitucional, estando prevista em lei ordinária ${ }^{303}$.

O programa eleitoral deve ser difundido para que a população a ele tenha acesso e possa avaliá-lo. Embora se trate de uma exigência bastante simples e que privilegia a accountability, na legislação comparada encontramos exemplos de países que não exigem a apresentação dos programas. Em outros, porém, a legislação impõe alguns requisitos em relação ao conteúdo dos programas. Idenficaremos brevemente o regramento atinente às propostas eleitorais na Espanha e em alguns países da América do Sul, a saber, Peru, Chile, Paraguai, Bolívia, Argentina, Venezuela, Equador, México e Colômbia.

O Código Eleitoral Espanhol define como campanha eleitoral o "conjunto de actividades licitas llevadas a cabo por los candidatos, partidos, federaciones, coaliciones o agrupaciones en orden a la captación de sufrágios", e tem duração de apenas $15 \operatorname{dias}^{304}$. Ao tratar dos atos permitidos em campanhas eleitorais, a Junta Electoral Central espanhola indica as formas por meio da quais o programa eleitoral pode ser transmitido: por meio de comícios, em qualquer meio de difusão, distribuição de folhetos, cartas, panfletos, ou em suporte eletrônico ( $\mathrm{cd}, \mathrm{dvd}$, memórias usb, etc), utilização de veículos particulares, envio de correio eletrônico ou mensagens sms, distribuição de conteúdo por radiofrequência (bluetooth) e pela criação ou utilização de páginas na rede mundial de computadores ou de compilação de textos e artigos (blogs), além da participação em redes sociais (Facebook, Twitter, etc $)^{305}$.

No Peru, a legislação vigente impõe a apresentação de um plano de governo pelos partidos aos candidatos a cargos executivos, devendo o plano permanecer exposto não

\footnotetext{
${ }^{303}$ Artigo 11, IX, da Lei Federal n 9.504/97, incluído pela Lei Federal n ${ }^{\circ} 12.034$ de 2009.

${ }^{304}$ Arts. 50 e 51.

${ }^{305}$ Instrucción 3/2011 da Junta Electoral Central sobre a interpretação do artigo 53 da Lei Orgânica do Regime Eleitoral.
} 
apenas no sítio eletrônico do partido, como no próprio órgão responsável pelas eleições, sob pena de indeferimento do registro da candidatura ${ }^{306}$. Provavelmente à vista da insuficiência de tal exigência, o Projeto de Código Eleitoral peruano prevê instruções para um delineamento dos requisitos que o plano deve conter, indicando que, no mínimo, deve incluir um diagnóstico, visão de país, objetivos e ações por setores em suas áreas de competência e conclusões ${ }^{307}$.

Estas características já são exigidas pela legislação do Chile, na qual as candidaturas a Presidente de República devem apresentar um programa no qual sejam indicadas as principais ações, iniciativas e projetos que se pretendem desenvolver em caso de sucesso na eleição, também sob pena de indeferimento da candidatura ${ }^{308}$.

Em situação diametralmente oposta, a legislação eleitoral do Paraguai, embora preveja que os partidos políticos devem possuir um programa, ao tratar da formalização de candidaturas, silencia a respeito da necessidade de apresentação de um plano de governo pelos candidatos ${ }^{309}$.

$\mathrm{Na}$ Bolívia, a lei estabelece que o acesso à propaganda eleitoral constitui um direito da cidadania como um marco dos direitos fundamentais à comunicação e à informação. Por isso, as agremiações políticas e os candidatos podem expor seus projetos e programas de governo. Entretanto, ao tratar da inscrição eleitoral não apresenta como requisito a entrega de um programa eleitoral de governo ${ }^{310}$.

$\mathrm{Na}$ Argentina não há previsão de entrega de programa eleitoral de governo pelos candidatos. A campanha eleitoral é definida como conjunto de atos "de movilización, difusión, publicidad, consulta de opinión y comunicación, presentación de planes y proyectos, debates a los fines de captar la voluntad política del electorado", a serem realizadas em um ambiente democrático e de tolerância ${ }^{311}$.

Ainda na América do Sul, na Venezuela também não há previsão de entrega de um programa eleitoral de governo, como tampouco ao tratar da propaganda se especifica que uma de suas finalidades é a apresentação de propostas. A campanha eleitoral é tida como o conjunto de atividades que tem por finalidade persuadir o eleitoral a votar em um determinado candidato. A propaganda eleitoral corresponde ao conjunto de peças

${ }^{306}$ Art. 23-A da Ley de Oganizaciones Políticas (Lei n $\left.{ }^{\circ} 28094\right)$.

307 Arts. 57 e 58 do Proyecto de Ley n ${ }^{\circ} 1.313 / 2016$.

${ }^{308}$ Art. 9 da Lei Orgánica Constitucional sobre Votaciones Populares y Escrutinios (Ley no 18.700/2016).

${ }^{309}$ Art. 157 do Código Electoral Paraguayo (Ley n 834/96).

${ }^{310}$ Art. 110 e 111 da Ley del Régimen Electoral, 30 de junio de 2010.

${ }^{311}$ Art. 64 "bis" do Código Electoral Nacional, Ley n 19.945.

132 
publicitárias que expressam mensagens eleitorais, sem esclarecer em que elas consistem, estabelecendo apenas o que é vedado na progaganda, como ofensa à honra, promoção de guerra e desobediência de leis, utilização dos símbolos nacionais, financiamento com fundos extrangeiros, etc ${ }^{312}$.

No Equador, a Ley Orgánica Electoral, denominada Código de la Democracia, estabelece que é obrigação do partido político, adequar sua conduta ao seu programa eleitoral de governo ${ }^{313}$. Todavia, a obrigação vem desprovida não apenas de sanção, como de meios de aferição do cumprimento de seu programa. Em outras palavras, trata-se apenas de um verdadeiro apelo ético, que se pretende transformar em norma jurídica, mas sem os instrumentos cogentes do direito.

A legislação do México distingue três tipos de mensagens de promoção política: propaganda eleitoral, políticoelectoral e institucional. A propaganda em pré-campanha já é entendida como o conjunto de manifestações nos quais são apresentadas "propostas" visando obter a candidatura a um cargo de eleição popular. A propaganda eleitoral propriamente dita tem por escopo a apresentação à cidadania das candidaturas registradas e deve propiciar a exposição, o desenvolvimento e a discussão com o eleitorado dos programas e ações fixados pelos partidos políticos em suas manifestações e particularmente da plataforma eleitoral para a eleição em questão ${ }^{314}$.

O país latino mais avançado em termos de exigência de cumprimento das propostas é a Colômbia, que criou o denominado "voto programático" para os cargos de governador e prefeitos, excluído, porém, o cargo de Presidente da República. A institucionalização do mandato imperativo pela via do voto programático busca uma aproximação da cidadania, visando afastar-se das debilidades estruturais da democracia representativa tradicional. A Constituição da Colômbia, em seu artigo 259 implementa o voto programático ${ }^{315}$.

Os candidatos aos cargos de governador e prefeito devem encartar ao pedido de inscrição eleitoral um programa eleitoral de governo, que será posteriormente publicado no

312 Art. 71, 73 e 75 da Ley Orgánica de Procesos Electorales. Cabe anotar que embora a Venezuela preveja no artigo 72 de sua Constituicao o mandato revocatório (recall), não há qualquer vinculação a descumprimento de propostas ou programa de governo. Assim, em tese, um governante poderia ter o mandato revogado, a despeito do cumprimento de seu programa, pela prática de ato pessoal incompatível com o cargo e em relação ao qual a população entendesse que ele deveria ser destiuído.

313 Art. 331.- Son obligaciones de las organizaciones políticas: 1. Adecuar su conducta a los mandatos constitucionales, a la ley, al acta constitutiva, a la declaración de principios ideológicos, a su programa de gobierno, a su estatuto o a su régimen orgánico según corresponda, y a su normativa interna;

${ }^{314}$ Art. 211 e 242 da Ley General de Instituciones y Procedimientos Electorales.

315 Artigo 259 da Constituição da Colômbia. Quienes elijan gobernadores y alcaldes, imponen por mandato al elegido el programa que presentó al inscribirse como candidato. La ley reglamentará el ejercicio del voto programático. 
órgão oficial da entidade respectiva para conhecimento geral. Uma vez eleitos, os prefeitos poderão propor junto ao legislativo municipal modificações ao plano de governo, nas sessões ordinárias seguintes à posse. Aprovadas as medidas, são encaminhadas ao respectivo órgão de controle de planeamento departamental correspondente dentro de um prazo de até 10 dias. Os governadores também podem submeter propostas de mudanças do plano à assembleia legislativa dentro do prazo de dois meses após a posse $\mathrm{e}^{316}$.

O voto é denominado programático porque o não cumprimento do programa pode dar ensejo ao processo revocatório, observados os requisitos legais, consistente em decurso mínimo de um ano de mandato e assinatura de ao menos $40 \%$ do total de votos válidos emitidos. O mandatário perderá o cargo se ao menos $60 \%$ dos cidadãos assim se manifestarem, podendo votar apenas aqueles que participaram da eleição que deu origem ao mandato e com número de votos não inferior a $60 \%$ dos votos registrados na eleição ${ }^{317}$.

Assim, os cidadãos colombianos ao votarem não elegem apenas um mandatário, mas escolhem um programa ao qual o eleito está encarregado de executar. Trata-se de um novo paradigma de relação entre a cidadania e a administração, em que os cidadãos, no momento eleitoral, intervêm de maneira prévia, aos assuntos de maior relevância e que mais os afetam. Trata-se de "reivindicar juridicamente o discurso político que se constrói nos espaços públicos" e também legitimar em termos democráticos as relações de poder ${ }^{318}$.

Uma escala de gradação entre os mencionados países acerca da relevância das propostas eleitorais e dos programas de governos permite classificá-los da seguinte forma: (a) baixa relevância, aqueles que sequer mencionam a entrega de programas de governo como etapa integrante do processo eleitoral - Espanha ${ }^{319}$, Paraguai, Argentina, Venezuela, Equador; (b) média relevância, países que exigem a apresentação de programa eleitoral de governo - Brasil, Peru, Chile e México; (c) alta relevância, exige-se a apresentação de um programa eleitoral de governo e propostas, sendo que o descumprimento pode dar origem a consequências jurídicas - Colômbia.

${ }^{316}$ Arts. $3^{\circ}$ a $6^{\circ}$ da Ley $131 / 1994$

317 Art. $7^{\circ}$ e $8^{\circ}$ da Ley $131 / 1994$.

318 SALAMANCA, Felipe Rey. Voto Programático y Programas de Gobierno en Colombia. Bogotá: Universidad del Rosario, Facultad de Jurisprudencia, 2015, p. 35.

${ }^{319} \mathrm{Na}$ Espanha, o candidato à presidência do governo será indicado pelo Rei através do Presidente do Congresso Nacional, após prévia consulta com os representantes dos grupos políticos de representação no parlamento. O candidato indicado apresentará então o programa político de governo, que será submetido ao voto de confiança do parlamento. (Art. 99, itens 1 e 2 da Ley de Ordenación del Regimen Electoral General $\left.n^{\circ} 5 / 1985\right)$. 
Deste panorama podemos concluir que as propostas de campanha, quando não complementamente ignoradas pelo processso eleitoral, possuem baixa ou nula eficiência do ponto de vista jurídico.

\subsection{Da necessidade de caráter cogente às propostas.}

No início do ano de 2018, no município de San Buenaventura, na Bolívia, o prefeito Javier Delgado foi fisicamente arrebatado por cidadãos locais, que pretendendo puní-lo por má gestão e "descumprimento de promessas de campanha", prenderam uma de suas pernas em um local público, impedindo-o de deixar-10 ${ }^{320}$.

A conduta, emboral naturalmente reprovável, presta-se a revelar o quanto o cumprimento das propostas eleitorais reclama uma maior atenção da esfera jurídica, com a existência de instrumentos que de alguma forma vinculem o comportamento políticoadministrativo do governante aos compromissos realizados.

O processo eleitoral inicia-se por meio de um complexo e intrincado procedimento. Os interessados filiam-se a partidos políticos, são escolhidos como representantes da agremiação para o pleito, realizam sua inscrição perante a Justiça Eleitoral, que convalida as candidaturas, bem como habilita os eleitores. Postas as regras para a apresentação das propostas por meio de propaganda, os candidatos, grupos políticos, partidos, se apresentam à população, realizam um diagnóstico dos problemas sociais, políticos e econômicos, apresentando efetivamente propostas para a mudança ou a continuação de melhoramentos. Em seguida, o povo vai à "festa da democracia", o dia do sufrágio, e são festejados os eleitos. Os vitoriosos discursam agradecendo a confiança depositada, prometendo cumprir o que foi anunciado em campanha. E, por fim, juridicamente, rompe-se totalmente o cordão que ligou o povo ao mandatário em relação aos compromissos realizados.

Chama à atenção o quanto realmente o sistema democrático parece contentar-se com as eleições como ápice do regime, mas imediatamente coloca o mandatário em uma zona de liberdade quase irrestrita, apta a negar todo o processo atingido até ali. Inexistem, em geral, mecanismos em relação aos quais os eleitos possam ser cobrados pelos compromissos assumidos durante a campanha eleitoral, de modo que toda a legitimidade democrática passa a repousar na mera expectativa de que o eleito cumprirá seu

320 "Comunidad de San Buenaventura pone al cepo a su alcalde Javier Delgado". El Deber. Santa Cruz de la Sierra, Bolívia. Disponível em: <http://www.eldeber.com.bo/santacruz/Comunidad-de-SanBuenaventura-pone-al-cepo-a-su-alcalde-Javier-Delgado-20180227-0001.html>. Acesso em 01/03/2018. 
compromisso moral com o povo que o elegeu, fazendo valer as propostas apresentadas, mesmo à míngua de um agente externo que imponha consequências ou mesmo parametrização quanto à extensão do nível de cumprimento/descumprimento.

Não é muito pouco para um sistema político tão relevante? Estaria o sistema relegado ao exercício arbitrário das próprias razões como no caso dos eleitores boliviamos? O controle seria limitado exclusivamente ao exercício da accoutability vertical, facultandose à cidadania a negativa de sufrágio em eventual nova candidatura? Não haveria outra forma de reforçar as efetivas escolhas do povo? Contentar-se apenas com a expectativa de lealdade dos governantes em detrimento da segurança das políticas públicas escolhidas certamente não representa uma expectativa de melhoria ${ }^{321}$. Se os programas eleitorais e os compromissos perdem valor após a eleição seria de se questionar em que medida a representação não é apenas um mito ficcional ${ }^{322}$.

O conceito de dever tem origem em uma obrigação moral. Ele assume contornos de dever jurídico na medida em que uma norma válida descreve uma sanção para a prática de determinada conduta considerada ilícita (lato sensu) ${ }^{323}$. As normas correspondem aos códigos de conduta compartilhados dentro de uma determinada comunidade, aceitos e respeitados. Quando são robustas, suas violações desencadeiam expressões de desaprovação ${ }^{324}$.

Todo homem que detém o poder é sempre tentado a dele abusar, sendo necessário e até indispensável - que o poder contenha o poder ${ }^{325}$. Para a verificação da existência e efetividade da autoridade é indispensável identificar como se dá a capacidade de reação

321 "Por conseguinte, um estado cuja salvação depende da lealdade de alguém e cujos assuntos só podem ser corretamente geridos se aqueles que deles tratam quiserem agir lealmente, não terá a mínima estabilidade Ao invés, para que ele possa durar, as suas coisas públicas devem estar ordenadas de tal maneira que aqueles que as administram, quer se conduzam pela razão, quer pelo afeto, não possam ser induzidos a estar de má-fé ou a agir desonestamente. Nem importa, para a segurança do estado, com que ânimo os homens são induzidos a administrar corretamente as coisas, contanto que as coisas sejam corretamente administradas. A liberdade de ânimo, ou fortaleza, é com efeito uma virtude privada, ao passo que a segurança é a virtude do estado". ESPINOSA, Baruch de. Tratado Político (Trad. Intr. e notas Diogo Pires Aurélio). São Paulo: WMF Martins Fontes, 2009, p. 9.

322 "El programa electoral constituye, pues, la base del programa de gobierno, el compromiso poítico asumido ante los electores y que se espera sea sancionado parlamentariamente en el acto de investidura. Como quisera que sea, hay que reconocer que, en ocasiones, puede producirse una cierta modulación o rectificación del programa electoral en su traslación al programa de gobierno, debida no tanto a la necesidad de acercarse a otros grupos políticos cuyo apoyo resulte fundamental, cuanto al conocimento de la auténtica situación, el la que se encuentra el país" GONZÁLEZ, María Holgado. El Programa de Gobierno y sus Sistemas de Control. Op. Cit., pp. 37-38.

${ }^{323}$ KELSEN, Hans. Teoria Geral do Direito e do Estado. Op. Cit., pp. 83-84.

${ }^{324}$ LEVITSKY, Steven e ZIBLATT, Daniel. Como as democracias morrem (Tradução Renato Aguiar). Rio de Janeiro: Zahar, 2018, p. 103.

325 “(...) tout homme qui a du pouvoir est porte à em abuser". MONTESQUIEU, Charles de Secondat. De l'esprit des loi. Paris: Vve Dabo, 1824, Livro XI, Cap. 4, p. 303. 
diante do descumprimento da norma e o seu conteúdo. Desta forma, a eficácia vincula-se aos instrumentos de coerção ${ }^{326}$.

É necessária uma ordem coercitiva para que as propostas eleitorais tenham maior respeitabilidade e eficácia. Afinal, o Direito é uma ordem coercitiva, pois em toda a história, caracteriza-se por obter um determinado comportamento social desejado de pessoas, instituições, empresas e países, mediante a ameaça de aplicação de determinadas medidas caso a conduta adotada seja distinta da estabelecida.

Francisco Suárez, ao tratar da natureza das leis, dizia que embora a sociedade deva submeter-se a elas, a própria legislação tem obrigações para com a sociedade, do ponto de vista de que devem ser outorgadas em direção ao bem comum. Lembra Suárez que os objetivos devem corresponder proporcionalmente aos atos, princípios e faculdades que a eles correspondem ${ }^{327}$. Logo, questiona-se qual seria a finalidade das campanhas eleitorais? Se é orientar o voto dos cidadãos visando a escolha do governo, seguindo-se os ensinamentos de Suárez, a ausência de instrumentos coercitivos relacionados ao cumprimento das propostas, bem correspondem a esvaziar seu objetivo, mercê da falta de exigibilidade, afastando-se, em última análise do próprio bem comum.

Retomando-se as lições de Francisco de Vitoria, se o governante comete abusos no poder, a República é competente para retirá-lo, sendo que a resistência do povo não deve se dar apenas com palavras em face um tirano, mas com "hechos", ou seja, uma resistência eficaz que justificaria inclusive o tiranicídio, em casos extremos. Realizada uma leitura dentro do contexto histórico vivenciado pelo autor, o que deve ser trazido para a contemporaneidade é o destaque de que o povo é o detentor da supremacia do poder e deve ser protagonista perene nos processos políticos ${ }^{328}$. Nesta linha de ideias, poderia buscar-se uma maior conexão entre a accountability e a responsiveness no que toca ao cumprimento das propostas eleitorais.

A natureza do Estado qualificado como democrático não se satisfaz com o processo de escolha de governantes e parlamentares. Ricardo Rivero Ortega lembra que a eleição confere legitimidade maior aos representantes "trasladando las propuestas de los

326 “A aplicação efetiva da norma jurídica depende, então, em cada caso particular, do fato de ter o sujeito do direito (ou o representante) interesse efetivo na aplicação da sanção, um interesse suficiente, para que ele inicie, por meio de sua 'ação judicial', o processo que leva à execução da sanção”. KELSEN, Hans. Teoria Geral do Direito e do Estado. Op. Cit., p. 120.

${ }^{327}$ SUÁREZ, Francisco. De Legibus I De Natura Legis. Edición crítica bilíngue por Luciano Pereña. Corpus Hispanorum de Pace. Madrid: Consejo Superior de Investigaciones Científicas, 1971, vol. XI, p 132.

${ }_{328}$ VITORIA, Francisco de. Relectio de Postestate Civili. Estudios sobre su Filosofía Política (Edición crítica por Jesús Cordero Pando). Corpus Hispanorum de Pace Segunda Serie. Madrid: Consejo Superior de Investigaciones Científicas, 2008, vol. 15, p. 444. 
programas políticos a las principales líneas de actuación, gracias a los médios personales y materiales que oferece el aparato administrativo"329. Se assim é, o governante tem a obrigação de direcionar sua atuação administrativa no sentido do cumprimento dos programas políticos apresentados na campanha eleitoral.

A autoridade, portanto, deve prever normativamente tanto a hipótese de cumprimento do comando, com sua regular execução e cumprimento, como ao mesmo tempo deve prever a hipótese de descumprimento da norma. Em ambas as alternativas, explica Bucci, devem ser encadeadas as hipóteses e as respectivas consequências. E quando as normas são reiteradamente descumpridas, a restauração da autoridade política e jurídica demanda a "quebra" do ciclo político vicioso, com novel edição normativa de atribuição, visando o restabelecimento da autoridade ${ }^{330}$. Daí a razão pela qual não há como se falar em valorização das propostas eleitorais sem que exista uma sanção para a hipótese de descumprimento.

A advertência realizada no capítulo anterior por Moisés em relação à falta de confiança como fator desestabilizante do regime democrático parece fortalecer a tese de uma maior clareza, compromisso e exigibilidade em relação às propostas eleitorais. Se o voto popular de um lado garante a formação do governo, em nada assegura juridicamente que as aspirações dos eleitores representarão o norte do governo.

O poder deve ser delimitado por balizas como forma de evitar o arbítrio e o abuso. Assim, sendo a confiança insuficiente como garantia de que haverá observância à efetiva representação, é necessário que determinados interesses sejam encapsulados de forma a garantir sua tutela. E além dos instrumentos de exercício de democracia direta, em que são legalmente protegidos tais interesses, são nas propostas de campanha eleitoral que o eleitor e o eleito estabelecem um liame jurídico, que malgrado não seja contratual, baseia-se na confiança de que o representante se guiará de forma coerente com o plano de governo e propostas apresentadas. Aliás, este constitui, em tese, o pressuposto para arregimentar a adesão a sua proposta ${ }^{331}$.

329 ORTEGA, Ricardo Rivero; AGUILAR, Víctor Granda. Derecho Administrativo. Quito: Corporación Editora Nacional, 2017, p. 36.

${ }^{330}$ BUCCI, Maria Paula Dallari. Fundamentos para uma Teoria Jurídica das Políticas Públicas. São Paulo: Saraiva, 2013, pp. 264 e 267.

331 “(...) saber se, de lege ferenda, o membro eleito de um corpo legislativo deveria estar juridicamente obrigado a executar a vontade de seus eleitores e, portanto, ser responsável para com o eleitorado depende da opinião sobre a amplitude em que é desejável que se concretize a ideia de democracia. Se é democrático a legislação ser exercida pelo povo, e se, por motivos técnicos, é impossível estabelecer uma democracia direta e se toma necessário conferir a função legislativa a um parlamento eleito pelo povo, então é democrático garantir, tanto quanto possível, que a atividade de cada membro do parlamento reflita a 
O sancionamento é indispensável para que um sistema que pretenda contemplar a efetividade obtendo resultados jurídicos práticos. A possibilidade de ser sancionado, com a inelegibilidade, por exemplo, é o que impulsionará o governante a buscar se valer dos mecanismos de coleta de preferência dos governados. Vale lembrar o conceito que assentamos no Cap. 1 no sentido de que a eleição não implica em uma transferência incondicional do poder, sujeita apenas à responsabilização eleitoral futura, mas sim conectado a uma administração que tem por pressuposto a democratic responsiveness.

Deste modo, repelem-se as teorias políticas segundo as quais a conduta política resultaria de um compromisso moral ${ }^{332}$ com a ordem social, mesmo que isso não atenda seus interesses ou que não exista um agente para corrigir desvios de conduta. Segundo tal entendimento, o pedestre não atravessa a rua com o sinal desfavorável porque o cumprimento das normas em caráter geral, beneficia a todos. $\mathrm{O}$ candidato, por sua vez, não se vale de recursos não contabilizados em campanha porque tem um compromisso moral com o povo ser transparente. Por tal razão, adverte Przeworski: "Como todo partido quer ganhar eleições, o acordo só prevalecerá se houver alguma força externa que o faça cumprir"333.

Se os programas eleitorais não dispõem de caráter cogente, os eleitos não têm qualquer compromisso com o que prometeram, de modo que toda a expectativa democrática passa a repousar na terceira hipótese trazida por Pzerworski quando tratamos da Teoria dos Jogos, ou seja, de que o eleito cumpra seu compromisso moral com o povo que o elegeu, fazendo valer as propostas apresentadas.

Rilke Branco sugere a criação de uma ação de improbidade contra a demagogia político-eleitoral, uma vez comprovada que a propaganda política e o marketing da campanha afastaram-se por completo da realidade, à luz de um juízo razoável de propositada desídia, inépcia ou incompetência do gestor público. O autor rejeita a ideia de

vontade dos seus eleitores. O chamado mandat impératif e a cassação de mandato de funcionários eleitos são instituições democráticas, desde que o eleitorado seja democraticamente organizado. A independência jurídica do parlamento diante do eleitorado pode ser justificada apenas pela opinião de que o poder legislativo é mais bem organizado se o princípio democrático, segundo o qual o povo deve ser o legislador, não for levado a extremos. A independência jurídica do parlamento em relação ao povo significa que o princípio de democracia é, até certo ponto, substituído pelo de divisão de trabalho. A fim de dissimular essa mudança de um princípio para outro, usa-se a ficção de que o parlamento "representa" o povo". KELSEN, Hans. Teoria Geral do Direito e do Estado. Op. Cit. pp. 417-418.

${ }^{332}$ Kelsen lembra que embora os julgamentos morais e políticos também pretendam expressar um valor objetivo, ou seja, pressupõe uma norma objetivamente válida, a existência e o conteúdo de tal normal não pode ser aferida por meio de fatos, e baseiam-se em ideologias. Idem, Ibidem, p. 69.

333 PRZEWORSKI, Adam. Democracia e mercado: reformas políticas e economicas no Leste Europeu e na America Latina. Rio de Janeiro: Relume-Dumara, 1994, p. 41. 
que a demagogia eleitoral possa ser vista com um simples erro de campanha, desvio de comunicação social ou abuso de propaganda eleitoral ${ }^{334}$.

Nossa pesquisa não se volta ao objetivo de tipificar criminalmente a conduta do agente público demagogo em campanha eleitoral, mas apenas tutelar a aferição quantitativa e qualitativa do cumprimento, viabilizar a existência de "contratos políticos", que serão tratados no capítulo seguinte, bem como conferir exequibilidade judicial a algumas propostas. A tese defendida por Rilke Branco parte do mesmo pressuposto que a nossa, ou seja, de que a falta de regramento e responsabilização pelas propostas realizadas em campanha deve receber freios normativos como forma de fortalecer o regime democrático.

A Lei Orgânica do Município de São Paulo, em seu artigo 69-A, aponta que o prefeito, eleito ou reeleito, deve apresentar o Programa de Metas de sua gestão, até noventa dias após sua posse, indicando as prioridades de seu governo, ações estratégicas, indicadores e metas para cada um dos setores da Administração Pública Municipal, Subprefeituras e Distritos da Cidade, observando, no mínimo, "as diretrizes de sua campanha eleitoral" e os objetivos, diretrizes, ações estratégicas e demais normativas do Plano Diretor Estratégico ${ }^{335}$. Nos parágrafos do referido dispositivo consta que o Plano será publicado, submetido a debate público e que o Poder Executivo deverá, semestralmente, divulgar os indicadores de desempenho.

Embora a medida represente um grande avanço, tanto no aspecto da accountability vertical, para que os administrados identifiquem as metas do governante que assumiu o poder, como em relação à responsiveness, já que a divulgação da evolução no cumprimento das metas, que devem observar as diretrizes de campanha, permitirá que se identifique o grau de atendimento das aspirações da coletividade, a disposição falha essencialmente em dois pontos.

O primeiro e mais grave é a falta de qualquer sanção para o descumprimento das obrigações impostas. Inexiste qualquer sanção jurídica caso o Plano de Metas não observe as propostas de campanha, mesmo que o grau de observância das diretrizes tenha sido mínimo ou até mesmo nulo.

Além de inexistir sanção também não há um instrumento jurídico que permita a tutela de determinados direitos, sendo que cabe ao próprio Poder Executivo indicar se as

334 BRANCO, Rilke Rithcliff Pierre. "Responsabilidades Político-Eleitorais, o Impeachment, a Improbidade e a Demagogia”. Revista Temas Socio-Jurídicos. Bucamaranga, Colombia, v. 36, ed. 73, julhodezembro, 2017, pp. 146-147.

335 Artigo adicionado pela Emenda n 30 à Lei Orgânica do Município de São Paulo. 140 
metas foram ou não cumpridas, e não por intermédio de um órgão autônomo e independente.

Podemos citar, por exemplo, o programa do Partido Socialista Espanhol (PSOE) prometia a criação de 800.000 postos de trabalho em 1982, o que não teria ocorrido, havendo na verdade, diminuição do número de vagas. Na campanha seguinte, o Partido Popular (PP) reiterava que tal promessa não fora cumprida ${ }^{336}$. Entretanto, como saber com segurança se a proposta foi ou não cumprida?

Trata-se, a nosso ver, de mudar o paradigma da representação político-democrática, robustecendo tanto o vetor do representante para com o representado como, reciprocamente, do representado para o representante, por meio de uma visão compromissária e dinâmica do instituto da representação. Retomando as lições de Urbinati, a presenca física imediata do cidadão no processo eleitoral deve conectar-se à presença mediata no governo, já a partir das propostas apresentadas. No dizer de Nino, na continuidade do diálogo que se iniciou no processo eleitoral entre candidato e cidadania, mas que prossegue agora com a transformação institucional em governante e cidadania.

Ainda que se trate de um vínculo político-eleitoral, é certo que o candidato em campanha realiza uma "oferta", no sentido de que em seu governo serão adotadas determinadas medidas, ao passo que o corpo eleitoral adere ou não a tais propostas, aceitando-o como governante. Acaso exista uma previsão legal de sanção para o descumprimento, não vemos razão para não qualificar esse vínculo como jurídico, e não exclusivamente político, também após a eleição.

No caso, a prestação obrigacional criada tem caráter coletivo, pois ainda que a promessa de campanha tenha por objeto uma questão específica de natureza individual, a construção do liame jurídico derivado da eleição decorreu da votação obtida pelo candidato. Trata-se, pois de um vínculo jurídico atípico, bilateral, estando de um lado o candidato eleito e de outro a coletividade responsável por sua eleição.

Como demonstramos anteriormente, muitas são as razões pelas quais um eleitor escolhe um candidato. Pode ele afeiçoar-se à agremiação do candidato, a suas propostas, sua experiência pessoal, sua origem, etnia ou até mesmo o simples fato de não ter seu nome envolvido em escândalos de corrupção. Qual critério tem maior ou menor influência na escolha do eleitor não foi objeto de nossa análise do presente estudo, mas apenas a

336 MARTÍNEZ i COMA, Ferran. ¿Por qué importan las campañas electorales? Colección $<$ Monofrafías>, n 260. Centro de Investigaciones Sociológicas. Madrid: EFCA S.A., 2008, p. 7. 
premissa de que as propostas eleitorais representam um importante liame que o candidato estabelece com a cidadania e que deve ultrapassar juridicamente a data da eleição e se tornar norma cogente no exercício da administração. Se de um lado a coletividade elege um candidato, mas não adere in totum a suas propostas, embora o veja como a melhor opção colocada, deve o governante ser obrigado a se orientar em direção das propostas.

Uma crítica quanto às propostas que apresentaremos e quanto às proposições impositivas certamente reside no fato de que, como mencionado, muitas são as razões que motivam a escolha de um candidato. Inclusive, às vezes o candidato pode ser escolhido apenas como forma de impedir que outro candidato/partido chegue ao poder. Assim, se os cidadãos ao elegerem um candidato, não aderem in totum a suas propostas, deve-se questionar se o governante seria obrigado a cumprir a proposta, mesmo diante de indícios de que a população não adere totalmente a seu compromisso. O primeiro argumento é no sentido de que se o candidato optar por oferecer as propostas, não sendo obrigado a fazêlo, deverá cumpri-las. Além disso, caso eventualmente o governante fosse persuadido de que tal medida seria contraproducente, poderia submeter a questão a instrumentos de manifestação popular direta, o que o liberaria do dever de cumprimento ou reforçaria a obrigação.

A existência de uma tutela das propostas de campanha eleitoral prevista no programa eleitoral implicaria, de plano, um maior cuidado da apresentação de tais propostas, na medida em que os partidos e governantes estariam cientes da sujeição a um órgão independente que aferisse a extensão do cumprimento da propostas, com consequências sancionatórias, bem como poderiam sofrer ações judiciais que implicassem na tutela específica do conteúdo das propostas. Tal desiderato já seria bastante positivo para as campanhas, tornando-as mais transparentes e menos populistas.

Em sentido contrário, embora reconheça a inconveniência de que os programas eleitorais tenham caráter exclusivamente ideológico e não passem de promessas vazias, Lorencini não entende viável, a transmutação dos programas eleitorais em obrigação jurídica de caráter cogente, sustentando que tais programas não possuem compromisso com a realidade estrutural, econômica e política do Estado, o que somente pode ser identificado após assunção ao cargo. Ainda que exista temperamento em relação a esta objeção no que toca às candidaturas à reeleição, Lorencini afirma que não se pode desconsiderar que os programas eleitorais são formatados na arena eleitoral, em ambiente 
de disputa política, com a fixação de metas e compromissos gerais, sem especificação de caminhos e procedimentos ${ }^{337}$.

Ao primeiro argumento, que já tratamos neste capítulo, afirmamos que malgrado se trate de mudança de paradigma político, sustentamos que aquele que pretende administrar um país, estado ou município, deve, minimamente, com o auxílio de pessoas que podem vir a fazer parte de tal projeto político, analisar de forma concreta algumas questões, trazendo um pouco mais de profissionalismo e realismo para a arena política ao apresentar proposições. Essa premissa parece relevante inclusive para responder a crítica de Brennan, que trouxemos no Capítulo 1, de que um dos problemas da democracia é que agentes despreparados passam a gerir a vida de toda a coletividade. Não nos parece que se trate de uma exigência elitista. Friso que não se exige do candidato especificamente o conhecimento, mas é necessário que antes da eleição, o candidato se aproprie de algumas questões junto com uma suposta equipe a ser formada. Tal medida é importante inclusive para o diálogo que é travado com os eleitores na campanha eleitoral. O mesmo argumento também se adequa à crítica de que durante a campanha eleitoral o cenário de disputa política autoriza a mera fixação de linhas mestras. Tal fato não impede que se exija maior profissionalismo dos candidatos em relação às propostas, inclusive porque como acreditamos ter demonstrado neste capítulo, as propostas não tem se prestado nem mesmo à fixação das linhas gerais, mas ao mero engodo eleitoral.

Nossa proposta possui três vertentes, na verdade, três níveis de profundidade.

No primeiro nível, na esfera administrativa, sugerimos que ocorra uma compilação e identificação das propostas eleitorais, por meio de órgão autônomo e independente, com o escopo de aferir de maneira técnica o nível de efetivo cumprimento das propostas eleitorais, com previsão de aplicação de sanções em determinados casos previamente estabelecidos em lei. Trataremos deste tópico no capítulo seguinte, denominando esse órgão como Agência de Verificação de Propostas Eleitorais.

Em um segundo nível, também na esfera administrativa, avançamos para além da compilação e verificação do cumprimento das propostas, permitindo-se a criação de "contratos políticos" propostos pelos candidatos, que voluntariamente se submetem a algumas consequências jurídicas em caso de descumprimento, como a impossibilidade de reeleição.

337 LORENCINI, Bruno. Democracia Qualificada e Responsabilidade Política. São Paulo: LiberArs, 2018, pp. 270-271. 
Em reforço à tese pela exigibilidade mesmo nestes casos, estará o "contrato político", delineado no Capítulo 5, em que o candidato descreve quais propostas são basilares a sua futura administração e a cidadania arcaria com os ônus de escolher um candidato que apresentasse um determinado conjunto de propostas. A cidadania passa a ser responsabilizada expressamente pela escolha do plano de governo, o que de forma valorativa, passaria a impor maior responsabilidade em relação ao sufrágio, nas apenas limitado à escolha de pessoas, mas de um conjunto que envolve o governante e as suas propostas.

No último nível, agora em sede judicial, propõe-se a criação de uma tutela coletiva das propostas eleitorais, em algumas hipóteses restristas e também como desdobramento de um "contrato político". Nestas hipóteses, o governo pode vir a ser compelido judicialmente ao cumprimento da proposta. O tema também é tratado no último capítulo da pesquisa.

Nossa proposta volta-se ao incremento do mecanismo jurídico, ou seja, do direito positivo, no dizer de Kelsen, sem apontar que tal adoção implicará em maior justiça ou qualquer outra apreciação moral ${ }^{338}$. A contribuição para a Ciência do Direito se concentra no primeiro e no terceiro nível, já que os denominados "contratos políticos", representam constribuicao de Hans Gersbach, professor da Universidade de Zurique.

338 "Direito e Justiça são dois conceitos diferentes. O Direito, considerado com distinto da justiça, é o Direito Positivo. É o conceito de Direito Positivo que está em questão aqui; e uma ciência do Direito positivo que está claramente distinguida de uma filosofia de justiça”. KELSEN, Hans. Teoria Geral do Direito e do Estado. Op. Cit., p. 8. 


\section{PARTE II - PROPOSTAS DE CONTROLE ADMINISTRATIVO E JUDICIAL DAS PROPOSIÇÕES ELEITORAIS}

\section{CONTROLE ADMINISTRATIVO DAS PROPOSTAS ELEITORAIS}

\subsection{Eficiência administrativa e avaliação da execução do plano de governo e demais propostas eleitorais.}

Embora para alguns doutrinadores o princípio da eficiência já decorresse diretamente do princípio da legalidade ${ }^{339}$, sua inserção de forma expressa no texto constitucional brasileiro ocorreu apenas pela Emenda Constitucional $n^{\circ} 19 / 98$, que significou a reforma do aparelho de Estado Brasileiro. Atualmente, a eficiência da Administração Pública está positivada como princípio no artigo 37, caput, da Constituição Federal de 1988. O artigo 103.1 da Constituição da Espanha, ao tratar da Administração Pública, também normativa o princípio da efetividade ${ }^{340}$.

A História mundial caminhou muito para atingir o atual estágio de exigência da Administração Pública e dos próprios gestores públicos. No final do Século XVIII as Revoluções Norte-Americana e Francesa colocaram fim ao absolutismo monárquico, em que o rei não podia ser responsabilizado por seus atos. O Estado pós-revolução tinha feição abstencionista, o que permitiu o desenvolvimento do capitalismo com liberdade de ação e contratação $^{341}$. Após a Primeira Grande Guerra, reconhecendo-se a necessidade de maior intervenção estatal, com a garantia de direitos individuais passa-se a positivar os direitos por meio do constitucionalismo. O imperativo de intervenção estatal aparece de forma mais clara com a depressão econômica de 1929 e, consequentemente, a partir de 1932, sob o governo do presidente norte-americano Franklin Delano Roosevelt, são inseridas reformas econômicas, de modo que o Estado passa a efetivamente criar empregos e

${ }^{339}$ MEIRELLES, Hely Lopes. Direito Administrativo Brasileiro. São Paulo: Malheiros, 2006, p. 90.

${ }^{340}$ Art. 103.1 "La Administración Pública sirve con objetividad los intereses generales y actúa de acuerdo con los principios de eficacia, jerarquía, descentralización, desconcentración y coordinación, con sometimiento pleno a la ley y al Derecho".

${ }^{341}$ MORAES, Antonio Carlos Flores de. Legalidade, Eficiência e Controle da Administração Pública. Belo Horizonte: Fórum, 2007, p. 23. 
produzir desenvolvimento nacional, em programa denominado New Deal. No final da década de 40 do Século XX propagou-se a ideia do Estado do bem-estar social e o ente estatal passou a promover diretamente serviços públicos como saúde, educação e previdência social, além de intervir em diversas áreas com o escopo de defender o interesse público e evitar o conflito social ${ }^{342}$. Esse comportamento estatal acabou por conduzir o ente nacional a um gigantismo complexo e difícil de controlar, de modo que se passou a um processo de descentralização e recuo da atividade estatal.

Segundo García-Pelayo o Estado social parte da experiência de que os sistemas autorreguladores da sociedade conduzem à irracionalidade de modo que somente a atuação do Estado por meio do desenvolvimento de técnicas administrativas, econômicas e de programação de decisões pode neutralizar os efeitos disfuncionais de um desenvolvimento econômico e social descontrolado ${ }^{343}$.

A atividade administrativa, portanto, caminha em processo evolutivo paralelo ao do desenvolvimento do Estado. Inicialmente pode-se afirmar a inexistência de prestação de serviço público, que evolui para o serviço público prestado, mas sobre o qual o administrador não podia ser responsabilizado. Em seguida, mercê do constitucionalismo, a legalidade passa a pautar a conduta do administrador. Entretanto, a legalidade formal, a mera subsunção da conduta administrativa à norma, tida até então como bastante, torna-se insuficiente face às demandas sociais e evolui para uma conduta administrativa formada a partir de maior participação popular e que se mostre eficaz, produzindo os resultados a que se dispunha em atendimento aos interesses da coletividade.

O conceito de eficiência, segundo Diogo de Figueiredo Moreira Neto, tem duas origens. De um lado, apartado da Ciência do Direito, como decorrência da Revolução Industrial, sendo definido como "relação entre um produto útil e aquele teoricamente possível com os meios empregados". Adentrando no ramo da Economia, o conceito de eficiência passou a se relacionar com o de "produtividade", enquanto "relação mensurável ou estimável entre produto e insumos". De outra vertente, já com base doutrinária de matriz jurídica, o conceito de eficiência foi desenvolvido em meados do Século XX na Itália, com a superação da administração sob aspecto burocrático, para o dever de "boa

${ }^{342}$ MORAES, Antonio Carlos Flores de. Legalidade, Eficiência e Controle da Administração Pública. Op. Cit., pp. 33 e 45.

${ }^{343}$ GARCÍA-PELAYO, Manuel. Las Transformaciones del Estado Contemporáneo. Caracas: Fundación Manuel García-Pelayo, 2009, pp. 22-23. 
administração", com novas concepções gerenciais buscando-se a eficiência na atuação administrativa ${ }^{344}$.

Moreira Neto aponta a eficiência administrativa como a "melhor realização possível da gestão dos interesses públicos", posta em termos de "plena satisfação dos administrados com os menores custos para a sociedade". Segundo o autor a "eficiência" simultaneamente se apresenta por meio de três características: (a) atributo técnico da administração; (b) exigência ética a ser atendida; (c) característica jurídica exigível, de boa administração dos interesses públicos ${ }^{345}$.

A busca pela maior eficiência, contudo, não pode significar o abandono de outros princípios constitucionais, como o da legalidade, conforme bem advertem Antonio Carlos Flores de Moraes ${ }^{346}$ e Maria Sylvia Zanella Di Pietro ${ }^{347}$. Da mesma forma, tampouco pode servir para que se busque fundamento e legitimidade exclusivamente no dispositivo constitucional que a consagra para que daí se presuma a ineficiência de uma determinada atividade, culminando sanções ao agente público. Quando se assevera que a eficiência é princípio e ao mesmo tempo norma, não se implica em presumir que a aferição da eficiência pode ser identificada em caráter subjetivo, sem a intermediação de normas infraconstitucionais que a definam, especifiquem e individualizem.

A tutela da eficiência não pode se legitimar no alargamento da discricionariedade. O princípio da eficiência não se volta contra a lei, mas efetivamente é complementado por ela, delineando para as diferentes atividades estatais objetivos, metas, parâmetros, forma de aferição e consequências para o atingimento dos resultados esperados e também para o caso de não obtenção do resultado. Do contrário, à míngua de específico delineamento legal, o princípio da eficiência, de forte retórica, mas de baixa densidade jurídica, quando analisado de forma isolada, pode implicar em incidência desarrazoada e arbitrária, gerando riscos à segurança jurídica e ao próprio Estado de Direito.

As qualidades da boa administração, portanto, devem ser aferidas por meio de parâmetros objetivos e previamente fixados como pressuposto da análise dos resultados alcançados, com a consequente incidência de consequências jurídicas decorrentes do atingimento ou não das metas estabelecidas, sob pena de utilização do princípio da

344 MOREIRA NETO, Diogo de Figueiredo. Curso de Direito Administrativo: parte introdutória, parte geral e parte especial. Rio de Janeiro: Forense, $2009,15^{\circ}$ ed. rev. ref. e atual, p. 117.

${ }^{345}$ Idem, Ibidem, p. 117.

${ }^{346}$ MORAES, Antonio Carlos Flores de. Legalidade, Eficiência e Controle da Administração Pública. Op. Cit., p. 195.

${ }^{347}$ DI PIETRO, Maria Sylvia Zanella. Direito Administrativo. Rio de Janeiro: Atlas, 2018, 31 ed. rev. atual. e ampl, p. 109. 
eficiência como instrumento de arbítrio. Tais parâmetros poderão estar fixados pela lei, por ato administrativo, por contrato administrativo e por ato administrativo complexo ${ }^{348}$.

Os conceitos de eficiência, eficácia, economicidade e efetividade apresentam grande imprecisão, de modo que o significado de cada qual muitas vezes é sobreposto por outro, especialmente os conceitos de eficiência e eficácia ${ }^{349}$. Isso ocorre porque tais conceitos não estão perfeitamente delineados em lei, de modo que cada hermeneuta acaba por lançar luzes sobre um determinado aspecto do instituto em detrimento de outro, gerando certa confusão de significados. Como nosso objetivo não é realizar um estudo analítico do princípio da eficiência, mas observar sua aplicação em relação ao controle das propostas eleitorais em cotejo com as políticas públicas, deixaremos de adentrar a seara de tais diferenciações.

Não se olvida que o controle de resultados da Administração apresente certo grau de ceticismo, exatamente porque muitas condutas administrativas não podem ser parametrizadas, ou ainda que o possam, sofrem efeitos externos alheios à vontade do administrador. Diante de tais situações o questionamento que se coloca é se devemos abandonar o princípio da eficiência e entendê-lo apenas como uma mera recomendação formal ou buscar a fixação de parâmetros legais para cada atividade administrativa, com foco em suas peculiaridades, visando aperfeiçoá-lo? A segunda hipótese, malgrado infinitamente mais complexa, é a que melhor se adequa ao atingimento do princípio da eficiência.

Cabe lembrar novamente, ainda, que no artigo 74, II, da Constituição Federal Brasileira, há determinação para que todos os poderes mantenham controle interno que avalie os resultados quanto à eficácia e eficiência da gestão orçamentária, financeira e patrimonial nos órgãos e entidades da administração federal e na aplicação de recursos públicos por entidades de direito privado. Dado o paralelismo constitucional o dispositivo aplica-se também aos Estados e Municípios.

Em síntese, onde há dispêndio de recursos públicos deverá haver fixação de metas e avaliação dos resultados colhidos, o que não constitui apenas aspecto jurídico, mas lógico com qualquer Estado que se intitule republicano, na medida em que o gestor público administra bens e valores que não lhe pertencem e são titularizados pela coletividade.

\footnotetext{
${ }^{348}$ MOREIRA NETO, Diogo de Figueiredo. Curso de Direito Administrativo: parte introdutória, parte geral e parte especial. Op. Cit., p. 117.

${ }^{349}$ MEDAUAR, Odete. Controle da Administração Pública. São Paulo: Revista dos Tribunais, 2012, $2^{\circ}$ ed. rev. atual. ampl., p. 72. 
A mensuração de resultados, a despeito dos problemas e desafios que comporta, contribui para a transparência da Administração Pública, gerando uma accountability focada em resultados. O clássico paradigma de que a Administração só pode fazer o que está determinado em lei, focando nos aspectos formais da gestão pública, deve ceder espaço para que a conduta da Administração seja focada nos resultados.

Em extensa pesquisa sobre a avaliação da qualidade universitária, Pilar Jimenez Tello esclarece que o conceito de "qualidade total" tem origem na filosofia empresarial japonesa da década de cinquenta no século $\mathrm{XX}$, relacionado à qualidade dos produtos, que cumpriam determinadas especificações. Como pressupostos da qualidade a autora aponta dois requisitos: que os serviços sejam oferecidos de acordo com "normas", que indiquem as especificações estabelecidas e que os serviços se adequem às expectativas ou necessidades, gerando satisfação aos clientes/usuários ${ }^{350}$.

A lição denota que a análise qualitativa de um objeto está vinculada à expectativa prevista dentro de um padrão normativo. O subjetivismo, rechaçado para efeito de controle qualitativo, residiria em aceitar que indivíduos ou grupos pudessem estabelecer aleatoriamente seu standard. Por tal razão, as diretrizes ou marcadores devem estar estabelecidas em "normas", permitindo seu cumprimento e avaliação. Uma administração de resultados dependente de normatização para que se promova segurança jurídica ${ }^{351}$.

Deverão, então, ser respondidas as seguintes questões: Quem avalia? Em que período? Como apontar o atingimento de um objetivo? Como estabelecer, em caso de não cumprimento, eventual aproximação com o padrão esperado? A fixação de indicadores estabelecidos de forma objetiva por meio de um órgão autônomo e independente é crucial para a efetividade do processo de análise. Retomaremos estes questionamentos mais adiante ao tratar da Agência de Verificação de Propostas Eleitorais.

Portanto, em uma fase preliminar, vale dizer que, por meio do arcabouço legislativo, se especificam os indicadores de avaliação, ou seja, quem avalia, para que, em seguida, preenchido um limite temporal, possam ser comparadas as ações e resultados empregados mediante o standard previamente fixado.

Retornando às proposições eleitorais, o conjunto de atividades relacionadas à responsividade eleitoral pode ser ordenado cronologicamente da seguinte forma: $1^{\circ}$ )

${ }^{350}$ TELLO, Pilar Jimenez. Auditoría Universitaria y Calidad. La evaluación como conquista social ante la competencia universitaria global. Saarbrücken: VDM Verlag Dr. Müller, 2009, pp. 115-116.

351 SOUZA, Rodrigo Pagani de. "Em Busca de Uma Administração Pública de Resultados". In: PEREZ, Marcos Augusto; SOUZA, Rodrigo Pagani de (coord.) Controle da Administração Pública. Belo Horizonte: Fórum, 2017. Edição Kindle, posição 1359. 
propostas eleitorais são realizadas pelos candidatos; $2^{\circ}$ ) eleito, o governante elege os meios pelos quais pretende atingir determinados objetivos, formando o conjunto de políticas públicas adotadas; $3^{\circ}$ ) mediante determinados critérios técnicos, realiza-se um cotejamento entre as propostas realizadas, a eleição das políticas públicas e os resultados efetivamente com elas obtidos; $4^{\circ}$ ) incidência de efeitos jurídicos em decorrência de determinados graus de descumprimento.

O sistema jurídico vigente contempla integralmente apenas as duas primeiras etapas. Em relação à terceira fase, existe atualmente análise da eficiência do gasto público, o que é realizado inclusive pelos Tribunais de Contas. Porém, esse exame tem por padrão os objetivos das políticas públicas de governo, mas não as propostas eleitorais. Nossa tese reside exatamente no que corresponde a melhor delinear a terceira etapa e avançar para a quarta, gerando, mediante previsão normativa, efeitos jurídicos como corolário do descumprimento das proposições. Os efeitos teriam duas naturezas, informativa e punitiva. A função informativa consiste na emissão de parecer, proveniente de agência, de natureza pública, criada exclusivamente para este fim, indicando metas que foram e que não foram cumpridas, visando cientificar a cidadania. A função punitiva se dará com a aplicação de sanções de acordo com o nível de descumprimento das propostas, podendo se atingir até mesmo a configuração de hipótese de inelegibilidade.

A inovação científica está na distinção de tratamento jurídico para as propostas eleitorais, cujo conteúdo até então, só tem relevo para o direito no que se refere à chamada propaganda negativa, que atinge outros candidatos ou terceiros, mas não em relação ao conteúdo dos compromissos assumidos. Por nossa proposta, alguns compromissos eleitorais passam a ser identificados com caráter obrigacional, impondo uma prestação por parte do governante, sob pena de, verificado o inadimplemento, não imputável a terceiro, sofrer consequências jurídicas que vão desde a exposição de tais dados por órgão público, passando por limitações orçamentárias até atingir as hipóteses de inelegibilidade e tutela judicial coletiva específica, em hipóteses bastante específicas.

\section{2 $O$ controle das políticas públicas e a parametrização estatística.}

Floriano de Azevedo Marques lembra que na concepção original o cidadão exercia o papel de titular de direitos, mas com o desenvolvimento do Direito Administrativo, paulatinamente passa a se transformar em destinatário passivo, beneficiário dos serviços públicos, que não são oponíveis ao Estado, já que este sempre agirá, presumivelmente, 
voltado à consecução do interesse público ${ }^{352}$. Dentre as funões que o particular exerce em relação à Administração Pública, Azevedo Marques arrola os papeis de súdito, de beneficiário, de cliente e de parceiro. Nos interessa o papel de beneficiário das funções públicas, em que mercê da ordem jurídica posta, impõe-se ao Poder Público o dever de prover políticas públicas, como as decorrentes de direitos fundamentis como direitos aa saúde, meio ambiente, cultura, educação, etc ${ }^{353}$.

As políticas públicas têm como ponto de partida a política, enquanto força originária que, permeada pelas normas democráticas se exterioriza no governo, sendo institucionalizada pelo direito, que se reconhece no Estado, com suas estruturas e funcionalidades ${ }^{354}$.

Marcos Augusto Perez, ao tratar da vinculação da atividade do administrator, em contraposição à discricionariedade, assevera que no poder vinculado a atuação da autoridade administrativa não oferece qualquer margem de liberdade ao agente, ao passo que no exercício do poder discricionário a legislação autoriza certo grau de liberdade de escolha, deixando de vinculá-la de forma absoluta. A liberdade, contudo, é limitada, circunscrita de forma instrumental às opções legais que possam, em tese, atender ao interesse público específico na prática de um determinado ato ou na tomada de uma determinada decisão ${ }^{355}$.

A ação política orienta-se por uma seleção dos "meios" para o atingimento do bem comum. Essa tarefa é essencialmente do governante, mas não o é de forma aleatória. E não se tratam aqui apenas das limitações impostas pelo direito em relação à "forma". O governante é responsável pela entrega de resultados, dentro de uma discricionariedade administrativa acerca dos meios de emprego. Isso implica dizer que a escolha ocorre entre

352 "Sintomática, neste sentido, é a passagem terminológica. O indivíduo vai gradualmente deixando de ser tratado no âmbito do direito administrativo como cidadão (o que remete a um polo detentor de direitos subjetivos em face ao Estado) e passa a ser considerado ou administrado (sujeito passivo da sujeição ao poder estatal) ou usuário (beneficiário passivo de um provimento administrativo). (...) O que se está a ressaltar é a crescente perda de importância do indivíduo em face ao Estado-Administração e a crescente autonomia do poder público em relação à sociedade. (...) Esta prevalência a priori vai reforçar a identificação do direito administrativo como vetor de efetivação da autoridade em detrimento de seu papel de instrumento de proteção da liberdade, um direito de promoção dos interesses supostamente gerais". MARQUES NETO, Floriano de Azevedo. "A Bipolaridade do Direito Administrativo e sua Superação". In: ARAGÃO, Alexandre Santos de; MARQUES NETO, Floriano de Azevedo (Coord.) Direito Administrativo e seus novos paradigmas. Belo Horizonte: Fórum, 2018, p. 108-109.

${ }^{353}$ Idem, Ibidem, p. 115.

${ }^{354}$ BUCCI, Maria Paula Dallari. Fundamentos para uma Teoria Jurídica das Políticas Públicas. São Paulo: Saraiva, 2013, p. 37.

${ }^{355}$ PEREZ, Marcos Augusto. "Controle da Discricionariedade Administrativa". In: PEREZ, Marcos Augusto; SOUZA, Rodrigo Pagani de (coord.) Controle da Administração Pública. Belo Horizonte: Fórum, 2017. Edição Kindle, posição 1964. 
diferentes alternativas válidas, dentro de um espectro de validade jurídica, para que a discricionariedade não desborde para a arbitrariedade ${ }^{356}$.

Como bem lembra Agesta diante de uma miríade de possibilidades visando a consecução do bem comum, podem ser assinalados objetivos e uma escala de meios, ao passo que diante do atingimento de cada objetivo, a barra pode ser elevada para conquistas superiores em termos de qualidade democrática. Contudo, para ele, a discussão e a determinação destas prioridades é uma tarefa essencialmente política e que se presta a moldar o processo de desenvolvimento da convivência humana ${ }^{357}$. A atividade política, logo, orienta os fins e o especialista deve dar os meios, como lembra Sartori ${ }^{358}$.

Por isso, a atividade de controle não consiste em pretender que o juízo reveja a conveniência e a oportunidade dos atos praticados, cuja legitimidade é circunscrita ao administrador, mas sim a realização de um controle finalístico quanto aos resultados obtidos em cotejo com os metas de governo ou os compromissos eleitorais propostos.

A parametrização estatística é um importante instrumento de análise de dados para aferição quanto ao atingimento dos resultados das políticas públicas adotadas, seu cotejamento com as metas de governo e, por consequência, das propostas realizadas. Alguns exemplos em que índices podem revelar a melhoria ou o agravamento da qualidade de serviços públicos são desempenho no nível médio de aproveitamento e evasão escolar, desemprego, mortes por doenças, percentual de pessoas assistidas com saneamento básico, índice de investimento público, índices de renda, violência com emprego de arma de fogo, etc. A compilação de uma universalidade de dados, com o devido tratamento e apresentação de pareceres circunstanciados, permite inclusive redirecionar verbas e esforços do governo, bem como orientar a cidadania na escolha do próximo governante.

Evidente, contudo, que a análise estatística de tais questões deve ter por fundamento critérios claros e iguais para efeito comparativo. Por exemplo, a medição níveis de desemprego ofecerá resultados distintos se a pesquisa abarcar todas as pessoas que estão fora do mercado de trabalho ou se incluir apenas aqueles que procuraram posto de emprego e não obtiveram sucesso ${ }^{359}$. Em relação à emissão de $\mathrm{CO} 2$, por exemplo, as

356 ORTEGA, Ricardo Rivero. AGUILAR, Víctor Granda. Derecho Administrativo. Quito: Corporación Editora Nacional, 2017, p. 148.

357 AGESTA, Luis Sanchez. Princípios de Teoría Política. 3. E.d. Madrid: Editora Nacional, 1970, p. 85 .

${ }^{358}$ SARTORI, Giovanni. A Teoria da Democracia Revisitada. Vol. 2. São Paulo: Ática, 1994, p. 230.

${ }^{359}$ No Brasil, existem dois indices governamentais que medem o índice de desemprego. O IBGE realiza a Pesquisa Nacional por Amostra de Domicílios Contínua - PNAD Contínua, e afere o nível de 152 
coletas de amostra devem ser realizadas com observância de determinados padrões técnicos previamente estabelecidos para que variações sazonais decorrentes de variação térmica, fluxo de veículos e período do ano não comprometam o resultado comparativo.

De qualquer forma, o que nos parece restar evidente é que tanto sobre lentes político-democráticas, como à luz de aspectos constitucionais e legais, as políticas públicas não apenas podem, como devem ser avaliadas em relação aos resultados alcançados, notadamente em cotejo com os objetivos iniciais a que se propunham.

Não é demais sublinhar que a avaliação das políticas públicas escolhidas em decorrência do processo eleitoral é de fundamental importância para a sustentação do regime democrático. Jimenez Tello, tratando da atividade empresarial, afirma que o controle de qualidade é tão importante que ignorá-lo pode gerar o risco de extinção das próprias empresas ${ }^{360}$. Mutatis mutandis ignorar as propostas eleitorais, aceitando-se a ideia de que não há compromisso efetivo com o seu atingimento ou de que não é possível qualificá-las representa crescente risco para a democracia, que refletiria um regime ineficaz, demagógico, aberto eventualmente a ser substituído por outro que ofereça maior eficácia.

\subsection{Entidades privadas de controle de políticas públicas.}

A análise de dados relacionados às políticas públicas pode ter origem governamental e não governamental. A Lei de Acesso à Informação, Lei Federal $\mathrm{n}^{\circ}$ 12.527, de 18/11/2011, ampliou o espectro de possibilidades de avaliação das políticas públicas por entes privados, cumprindo importante função ao viabilizar como direito subjetivo o acesso a dados das contas públicas e impondo à administração o dever de disponibilização online de dados e informações administrativas. Embora se trate de grande

desemprego com base no número de pessoas que, no período de apuração, procurou emprego e nao encontrou. Não abrange, portanto, eventuais desempregados que não procuraram postos de trabalho. De outro lado, o Cadastro Geral de Empregados e Desempregados (CAGED), criado pela Lei Federal no 4.923/1965, e hoje vinculado ao Ministério da Economia, compila apenas os dados de emprego formal, ou seja, com registro em carteira de trabalho.

360 "La calidad es un fator importante en el mundo de la empresa; si las empresas no ofrecen produtos de calidad al mercado y no escuchan su demanda corren peligro de extinción, solo sobreviven aquellas empresas que tienen unos sistemas de organización moderna acorde a lo que la sociedade y el mercado demandan; Estamos, como venimos diciendo a lo lado de esta investigación, en un mundo globalizado y competitivo y solo sobrevivirán las mejores, es decir las que ofrescan productos destacados y solo podrán oferecer productos destacados aquellas que tengan estabelecidos sistemas de gestión y producción acordes com el mercado". TELLO, Pilar Jimenez. Auditoría Universitaria y Calidad. La evaluación como conquista social ante la competencia universitaria global. Op. Cit., p. 116. 
avanço, a medida é bastante recente se comparada com outros países, de forma que a abertura de dados até pouco tempo atrás não refletiva uma tradição política brasileira ${ }^{361}$.

Como exemplo de organização não governamental de produção de estatísticas podem ser citadas, no Brasil, a Rede Nossa São Paulo e o Fórum de Segurança Pública. O controle por órgãos governamentais será explicitado no item seguinte.

A Rede Nossa São Paulo é uma entidade civil que visa o comprometimento de governos com uma agenda e conjunto de metas, mirando a melhoria da qualidade de vida no município de São Paulo. Em parceria com instituições públicas e privadas tem como uma de suas diretrizes estabelecer um programa de indicadores e metas, selecionando os principais parâmetros de qualidade de vida para a região das subprefeituras da cidade. Além disso, faz o monitoramento sistemático dos trabalhos da Câmara Municipal de São Paulo e acompanha o orçamento municipal. A Emenda n 30 à Lei Orgânica do Município de São Paulo que instituiu que o prefeito, eleito ou reeleito, deve apresentar o Programa de Metas de sua gestão, até noventa dias após sua posse (art. 69-A), é fruto de proposta da Rede Nossa São Paulo, que também encaminhou projetos de emenda para as esferas estadual e federal. Em paralelo a Rede faz o acompanhamento das propostas por meio do programa "De olho nas Metas", gerenciado por uma plataforma digital que tem por objetivo auxiliar a sociedade civil a acompanhar a execução das metas em cada região do município, bem como o andamento de outras obras da prefeitura ${ }^{362}$.

O Fórum de Segurança Pública também é uma organização sem fins lucrativos com o objetivo de formentar o debate, a articulação e a cooperação técnica para a segurança no Brasil. O Fórum compila dados estatísticos, promove encontros técnicos, publica revista e elabora projetos oferecendo diagnósticos locais de violência ${ }^{363}$.

A despeito da relevância para a promoção da accountabiliy, na medida em que as organizações realizam o tratamento de dados compilados e fomentam o debate entre a cidadania e o governo, não estão sujeitas a verificação técnica, ou seja, não há controle sobre os resultados estatísticos, por se tratarem de entes privados. Além disso, embora as

${ }^{361}$ Legislação semelhante, impondo o acesso a informação foi aprovada na Suécia em 1766. "His Majesty's Gracious Ordinance Relating to Freedom of Writing and of the Press" Estocomo, 02/12/1766. Disponível em: < http://www.chydenius.net/pdf/worlds_first_foia.pdf > p. 8, tradução de Peter Hogg. Acesso em $05 / 01 / 15$.

$362 \quad$ Disponível em: <https://www.nossasaopaulo.org.br/\#iniciativas $>\quad$ e https://2017.deolhonasmetas.org.br/o-que-e/>. Acesso em: 19/02/2019.

363 Disponível em: <http://www.forumseguranca.org.br/perfil/apresentacao/>. Acesso em: $19 / 02 / 2019$. 
entidadades sejam não governamentais, são entidades privadas que possuem agenda, princípios e objetivos particulares legítimos.

Tais iniciativas mostram que a própria sociedade civil tem se movimentado para analisar se as propostas dos governantes vem sendo cumpridas. Nesta linha, em síntese, a análise das políticas públicas à luz das propostas eleitorais, objeto de nosso estudo, consiste na resposta às seguintes perguntas: a sociedade está sendo conduzida na direção proposta pelos governantes? O Estado atualmente pode responder a esta pergunta de forma institucional?

\subsection{Agências governamentais de análise de estatísticas.}

As agências governamentais de controle de estatísticas são órgãos ou entes que fazem parte da estrutura administrativa de uma unidade federativa, de um país ou de um bloco de países. Trataremos em linhas gerais dos princípios, formas de administração e estrutura de alguns órgãos estatísticos mundiais e nacionais.

A EUROSTAT foi criada em 1953 e produz estatísticas relacionadas à União Européia, fazendo a interlocução com cada país integrante do bloco por meio da autoridade estatística nacional local ${ }^{364}$. As estatísticas são determinadas pelo Programa Estatístico Europeu (art. $1^{\circ}$ ) e tem como princípios estatísticos: a "independência profissional", particularmente em relação à seleção de técnicas, definições, metodologias e fontes, calendário e conteúdo, devendo o desempenho de tais funções ser isento de pressões de grupos políticos, de interesse ou de autoridade da Uniao Europeia ou estados nacionais; “imparcialidade, objetividade, confiabilidade, segredo estatístico, relação custo-benefício. Este último se refere ao custo de produção de estatística, que deve ser proporcional à importância do resultado.

Quanto à estrutura orgânica a EUROSAT é conduzida por um Diretor-Geral, responsável exclusivo pela tomada de decisões sobre processos, métodos, normas e procedimentos estatísticos, e sobre o conteúdo e o calendário de difusão dos dados estatísticos e das publicações de todas as estatísticas produzidas pela Comissão (Eurostat), agindo de forma independente, não devendo procurar nem aceitar instruções das instituições ou organismos da União Europeia, nem de governos ou de outras instituições,

$364 \quad$ Disponível em: <https://ec.europa.eu/eurostat/statisticsexplained/index.php?title=Glossary:Eurostat $>$. Acesso em 22/11/2018. 
órgãos, serviços ou agências, preservando-se a imparcialidade e a confiabilidade (art. $6^{\circ}$ ). O Comitê do Sistema Estatístico Europeu oferece orientação profissional ao Sistema de Estatísticas Europeu (SEE) e é composto por representantes das instituições estatísticas nacionais, que devem ser peritos nacionais em matéria de estatísticas (art $7^{\circ}$ ). A exigência, a despeito de óbvia, é relevante para dificultar o apadrinhamento de nomeações. Sobre a qualidade das estatísticas devem ser observados os seguintes atributos (art. 12) pertinência, precisão, atualidade, pontualidade, acessibilidade, comparabilidade e coerência.

Mercê da preocupação com a fidelidade dos dados compilados, em caso de omissão ou deturpação de dados por um Estado-Membro que pretenda ocultar alguma realidade estatística, além da possibilidade de imposição de multas, pela legislação específica de cada setor, a Comissão da EUROSTAT poderá realizar a investigação necessária, incluindo-se inspeções locais.

Em relação à administração, o Programa Estatístico Europeu (art. 13) estabelece o quadro para o desenvolvimento, produção e divulgação das estatísticas europeias e os principais domínios e objetivos das ações previstas para um período plurianual. A Comissão elabora o parecer e o submete ao Sistema de Estatísticas Europeu (SEE). O Programa é aprovado pelo Parlamento Europeu e pelo Conselho.

O STATISTICS CANADA ${ }^{365}$ é o órgão responsável por coletar, compilar, analisar, resumir e publicar as informações estatísticas relacionadas às atividades e condições, comerciais industriais, financeiras, sociais, econômicas e gerais da população no Canadá. O órgão está submetido ao Ministério da Inovação, Ciência e Desenvolvimento Econômico. O chefe do instituto será nomeado pelo Chefe do Conselho e detém o mandato por até 5 anos, podendo ser reconduzido. Porém, pode vir a ser removido pelo Chefe do Conselho por justa causa. O Conselho é formado pelo "Chief Statistician" juntamente com dez integrantes indicados pelo Chefe do Conselho. As diretivas sobre quaisquer métodos, procedimentos e operações só podem ser emitidas ao Chefe de Estatística pelo Governador no Conselho, por recomendação do Ministro. O Chefe Estatístico (“Chief Statistician”), ao assumir o cargo, faz um juramento afirmando que cumprirá fiel e honestamente seus deveres e preservará o sigilo das informações obtidas. $\mathrm{O}$ juramento deve ser registrado. $\mathrm{O}$ “Chief Statistician” tem poderes de contratação de pessoas físicas e jurídicas. Caso seja uma pessoa jurídica, o seu chefe executivo igualmente deverá prestar a solenidade de juramento.

\footnotetext{
${ }^{365}$ Statistics Act R.S.C. 1985, alterado pela Royal Assent em 12/12/2017, artigo $6^{\circ}$. 156
} 
Nota-se que o órgão é centrado na figura do Chefe de Estatísticas, que pode requisitar informações, determinando se elas devem ser prestadas em caráter voluntário ou mandatório. A lei pode estabelecer as áreas em que a Agência deverá verificar o cumprimento das propostas ${ }^{366}$.

O órgão responsável pelas estatísticas na China "CHINA STATISTICS" prevê em seus atos constitutivos que o trabalho dos estatísticos deve ser "independente e livre de interferências" $" 367$.

Da mesma forma o INSTITUTO NACIONAL DE ESTADISTICA ESPAÑA é constituído como órgao autônomo, com patrimônio próprio e personalidade jurídica, vinculado ao Ministério da Economia e Empresa ${ }^{368}$. A legislação nacional determina que todos os órgãos das províncias, municípios e demais órgãos da Administração Pública forneçam os dados necessários solicitados pelo Instituto ${ }^{369}$.

\section{No Brasil, o IBGE (INSTITUTO BRASILEIRO DE GEORGRAFIA E} ESTATÍSTICA) é o órgão nacional responsável pela produção de estatísticas. O instituto é constituído como fundação pública, vinculado ao Ministério do Planejamento, Desenvolvimento e Gestão. Em seu estatuto os objetivos são assegurar a produção e análise de informações estatísticas, geográficas, cartográficas, geodésicas, demográficas, sócio-econômicas, de recursos naturais e de condições do meio ambiente, inclusive poluição, necessárias ao conhecimento da realidade física, econômica e social do País, em seus aspectos considerados essenciais ao planejamento econômico e social e à segurança nacional.

O órgão é composto pelo Presidente, nomeado pelo Presidente da República ${ }^{370}$, e pelos órgãos colegiados, Conselhos Técnico, Curador e Diretor. O Conselho Técnico é composto pelo Presidente do IBGE, que o presidirá, e por dez Conselheiros escolhidos e designados pelo Ministro de Estado do Planejamento, Orçamento e Gestão, dentre

${ }^{366} \mathrm{O}$ órgão de estatística canadense (Statistics Canada) no artigo 22 do Statistics Act arrola as áreas que devem ser objeto de análise, sem prejuízo de outras estatísticas específicas: (a) população; (b) agricultura; c) saúde e bem-estar; (d) aplicação da lei, administração da justiça e penas; (e) governo e finanças empresariais; (f) imigração e emigração; (g) educação; (h) trabalho e emprego; (i) comércio com outros países; j) preços e custo de vida; k) silvicultura, pesca e caça; l) minas, pedreiras e poços; (m) indústria; (n) construção; (o) transporte, armazenamento e comunicação; (p) concessionárias de energia elétrica, gás e água; (q) comércio atacadista e varejista; (r) finanças, seguros e imóveis; (s) administração pública; (t) comunidade, negócios e serviços pessoais; e (u) quaisquer outros assuntos prescritos pelo Ministro ou pelo Governador no Conselho.

${ }^{367}$ Art. $6^{\circ}$ da Lei de Estatística da República da China de 08/12/1983, revisada em 27/06/2009.

${ }^{368}$ Ley $12 / 1989$.

369 Artigo 40 da Ley 12/1989.

${ }^{370}$ Art. 27 do Estatuto do IBGE (Decreto $n^{\circ} 76664$ de 24 de novembro de 1975). 
cidadãos brasileiros de reconhecida representatividade e competência técnica e profissional na área da produção ou utilização de informações estatísticas e geocientíficas ${ }^{371}$. O mandato será de 4 anos, permitida a recondução. Os cinco membros do Conselho Curador também serão nomeados integralmente pelo Ministro de Estado do Planejamento, Orçamento e Gestão. A representação dos integrantes da carreira fica limitada a 2 cargos, em que servidores de vínculo efetivo concorrem internamente para a formação de lista sêxtupla, na qual os dois nomes serão escolhidos pelo Ministro do Planejamento.

No Estado de São Paulo, a FUNDAÇÃO SEADE (Sistema Estadual de Análise de Dados) é constituída como fundação vinculada à Secretaria de Governo. Entre suas finalidades encontra-se a coleta, organização, análise e divulgação de informações técnicas e dados estatísticos, bem como a identificar a situação do desenvolvimento econômico e social do Estado, a definição de metodologias e formas de execução no âmbito da Administração centralizada e descentralizada do Estado, o acompanhamento de programas e projetos governamentais e informações sobre o seu andamento, além da divulgação, para a sociedade como um todo, de informações técnicas e dados estatísticos ${ }^{372}$. A composição diretiva da Fundação reúne o Presidente, o Conselho de Curadores e a Diretoria. Os membros do Conselho de Curadores cumprem mandato de 5 anos, renovável por igual período uma vez, e são todos designados pelo Governador do Estado, livremente ou após análise de listas tríplice elaboradas pelos órgãos e entidades previstos em lei. O presidente também é indicado pelo Governador, entre pessoas com “notório saber e reputação ilibada", para mandato de 5 anos, igualmente renovável uma única vez. O Diretor Executivo e os Diretores Adjuntos também serão indicados pelo Governador dentre pessoas indicadas em listas tríplices apresentadas pelo Conselho de Curadores ${ }^{373}$.

A análise da estrutura dos institutos de estatística governamentais permite observar que se trata de órgãos cujo grau de independência sofre variação no que toca à maior ou menor permeabilidade à influência do poder político em aspectos institucionais.

Retomamos aqui o argumento relacionado às democracias menos consolidadas, em que para determinados órgãos, como de análise de estatísticas, a permeabilidade política deve ser bastante neutralizada ${ }^{374}$. No caso da FUNDAÇÃO SEADE, por exemplo, nota-se

${ }^{371}$ Artigo $9^{\circ}$ do Decreto ${ }^{\circ} 4.740$ de 13 de junho de 2003 .

${ }^{372}$ Lei Estadual $n^{\circ} 1.866 / 78$, artigo $3^{\circ}$.

${ }^{373}$ Lei Estadual n ${ }^{\circ} 1.866 / 78$, artigos $6^{\circ}$ a 11.

${ }^{374}$ No Brasil, o então presidente do INPE (Instituto Nacional de Pesquisas Especiais), Ricardo Galvão, defendeu a divulgação de pesquisa realizada pelo instituto que mostrava avanço do destamatamento na região amazônica. O Presidente de República, Jair Bolsonaro, criticou a pesquisa e a decisão do órgão de 
que o Governador do Estado tem controle integral sobre todos os pólos dirigentes do órgão - Presidência, o Conselho de Curadores e a Diretoria - o que reduz substancialmente a independência do órgão e dificulta que estatísticas francamente desfavoráveis ao governador tenham grande chance de obter destaque nos relatórios.

Daí a dura conclusão de que o Estado encontra dificuldades para se auto-avaliar, pois o interesse político se sobrepõe ao interesse de fornecer uma informação precisa e isenta à população, especialmente pelo risco de ser a informação prejudicial ao gestor do ponto de vista político. Por estas razões, durante o governo, não se sabe exatamente: (a) se as propostas estão sendo cumpridas; (b) e se estão sendo cumpridas, em que medida; (c) se não estão sendo cumpridas, por qual razão. E como consequência, ao final do governo não haverá respostas para tais perguntas e tampouco instrumento para determinar que o governo oriente a sua atuação neste sentido.

\subsection{O Estado e o dever de tutela da veracidade das informações públicas.}

A discussão sobre a mentira gravita de forma mais próxima à esfera da ética, e não do direito, especialmente na esfera privada. O direito ocupa-se, porém, dos efeitos causados pela mentira, identificando-se eventuais danos efetivos ou potenciais ${ }^{375}$.

A democracia tem por escopo a pacificação e acomodação das diferenças de opinião. No dizer de Nadia Urbinati, "a democracia é única porque ela extrai a força da unidade das diferenças" ${ }^{376}$. Admitir as diferenças e que dela se extrai a unidade não implica em aceitar que as notícias falsas devam ser aceitas como inerentes a uma sociedade livre. Ao contrário, elas são perniciosas a qualquer regime democrático.

Os cidadãos tem o direito básico à informação em uma democracia. O exercício pleno e asséptico ao direito de voto demanda inexoravelmente o conhecimento sobre informações críveis acerca do que os líderes eleitos estão produzindo ${ }^{377}$. A verdade é essencialmente um dos pilares dos regimes democráticos, ao passo que a demagogia é um

publicá-la e, após discussão de ambos por meio de impressa, Ricardo foi exonerado. "Bolsonaro confirma que solicitou exoneração de diretor do Inpe". Disponível em: <https://exame.abril.com.br/brasil/bolsonaroconfirma-que-solicitou-exoneracao-de-diretor-do-inpe/>. Acesso em 21/10/2019.

375 RAIZ, Diogo. "Fake News e Eleições". In: RAIZ, Diogo (coord.) FAKE NEWS: a conexão entre a desinformação e o direito. São Paulo: Thomson Reuters Brasil, 2018, p. 106.

376 Tradução nossa do original: "Democracy is unique because it extracts the strengh for unity from diferences”. URBINATI, Nadia. Representative Democracy. Chicago: University of Chicago Press, 2006, p. 30 .

377 LEVITSKY, Steven e ZIBLATT, Daniel. Como as democracias morrem. (Tradução Renato Aguiar). Rio de Janeiro: Zahar, 2018, p. 189. 
importante instrumento de controle social por parte dos regimes autoritários. Nesta linha de ideais, trazer a discussão sobre a verdade para o centro do cenário político implica, não em ignorar que não há como impedir que os políticos professem mentiras, mas em prever consequências jurídicas para as hipóteses em que a mentira, leia-se em paralelo, a demagogia, é identificada.

É função do direito impedir o abuso ao exercício do poder. Além da clara hipótese em que o procedimento, aqui tomado como a sequência legal de atos a serem praticados não é observada, também cumpre anotar que o direito deve, dentro dos limites normativos, combater as condutas que destoem das finalidades públicas a que estão vinculadas. $\mathrm{O}$ Estado tem o dever de orientar e regular o acesso a tais informações.

Em várias sociedades contemporâneas observa-se um declínio do interesse pela verdade, passando-se a admitir "fatos alternativos", que rejeitam ou ignoram o produto da ciência. Pretende-se criar um ambiente em que o resultado científico equivale a uma opinião pessoal e possa ser questionado nesta exata medida. Glorifica-se a impressão pessoal, individual ou coletiva, em detrimento do conhecimento, em fenômeno cunhado de era da "pós-verdade". Nesta linha podem ser citados os movimentos antivacina, as correntes que negam as mudanças climáticas, as propostas revisionistas sobre eventos históricos como o Holocausto ${ }^{378}$ e o regime autoritário no Brasil após 1964.

A utilização de mentiras e exageros na esfera política sempre existiu. Aliás sua origem remonta ao advento da comunicação humana. Porém, o que agrava a situação no atual momento histórico é que as informações falsas são substanciadas pela multiplicação de mensagens de conteúdo falso, disseminadas pelas redes sociais como o Facebook, que se escudam no anonimato da rede, e cujas mensagens são catapultadas por trolls, mecanismos de inteligência artificial que fazem tais notícias circularem com grande velocidade e abrangência. A verossimilhança passa a ocupar o espaço que caberia à verdade, sendo compartilhada até "viralizar"379.

378 "Negar Holocausto não é liberdade de expressão, decide corte europeia". Disponível em: < https://www.dw.com/pt-br/negar-holocausto-n\%C3\%A3o-\%C3\%A9-liberdade-de-express\%C3\%A3odecide-corte-europeia/a-50697201>. Acesso em: 07/10/2019. A Corte Europeia de Direitos Humanos (ECHR), confirmando decisão da justiça alemã, reconheceu que negar a existência do Holocausto ou colocálo em dúvida não constitui um direito fundamental e, portanto, não está abrangido pela liberdade de manifestação. Trata-se exatamente de reconhecer que determinados fatos históricos, de grande envergadura, não podem simplesmente ser negados, havendo um dever estatal, ou supraestatal na espécie, de se tutelar a verdade.

${ }^{379}$ Nas investigações relacionadas às eleições presidenciais nos Estados Unidos em 2016, foram identificados trolls russos que criavam embates com o objetivo de minar o sistema democrático. Em um episódio, foi utilizado um perfil falso denominado "Heart of Texas" para organizar um protesto denominado "Acabe com o islamismo no Texas". Ao mesmo tempo, outro perfil falso, organizou para o mesmo local e 160 
O termo "fake news" é adotado para descrever a publicação de notícias sabidamente falsas. Em um sentido mais restrito, porém, pode ser conceituado como uma manchete e notícia sabidamente falsa, escrita e publicada em sítio eletrônico criado para que aparente tratar-se de um sítio eletrônico real de notícias, objetivando sua difusão por mídia social ${ }^{380}$. As notícias revestem-se de caráter jornalístico com o intuito de granjear verossimilhança ao conteúdo, mas são adrede preparadas para incultar insidiosamente conteúdo falso e difamatório. A denominação também tem sido utilizada por políticos para cunhar qualquer tipo de notícia que lhes seja desfavorável.

No ambiente da rede - na internet - existe uma simbiose circular que envolve as plataformas digitais, os anunciantes e o sistema de coleta de dados. Quanto mais tempo um usuário utiliza uma plataforma, mais anúncios a empresa vende e, em tese, mais lucro obtém. Os dados do usuário e de seus interesses são coletados, para que ele continue utilizando a plataforma e, assim, diante de mais anúncios, oferece-se a ele exatamente mais daquilo que ele estava interessado. Esse comportamento reforça posicionamentos unilaterais, criando filtros que mantém as pessoas em "bolhas partidárias"381.

$\mathrm{Na}$ esfera política esse comportamento contribui para a desqualificação do debate sério, pois opiniões que simplesmente rejeitam visões contrárias são reforçadas por notícias falsas que substanciam as teses esposadas, por mais esdrúxulas que sejam, como a teoria defendida pelos terraplanistas.

Neste caótico cenário, de desprezo da ciência, o objetivo de alguns políticos não se volta ao convencimento da veracidade das informações, mas sim da geração de dúvidas, incutindo medo e sensação de impotência. Não surpreende que questões relacionadas a "edemocracia" (democracia digital), disseminação de notícias falsas por perfis falsos de redes sociais e algoritmos que transmitem informações de forma enviesada sejam questões que se encontram na pauta das discussões contemporâneas.

Existe um aparente conflito na relação entre dois valores fundamentais, o direito de expressão e a democracia quando pensamos na limitação do primeiro como instrumento de preservação e efetividade do segundo, dada a relevância que as informações falsas podem repercutir no processo eleitoral. Segundo Clarissa Gross, essa relação entre liberdade e

data, um contraprotesto organizado pelo perfil, também falso, chamado "United Muslims of America". KAKUTANI, Michiko. A Morte de Verdade. (Trad. André Czarnobai, Marcela Duarte). Rio de Janeiro: Intrínseca, 2018, p. 60.

${ }^{380}$ ROCHLIN, Nick. "Fake news: belief in post-truth", Library Hi Tech, Vol. 35 Issue: 3, p. 388, (2017). Disponível em: <https://doi.org/10.1108/LHT-03-2017-0062>. Acesso em 18/05/2019.

${ }^{381}$ KAKUTANI, Michiko. A Morte de Verdade. Op. Cit., p. 155. 
democracia pode ser analisada sob duas óticas: tendo a liberdade de expressão como valor instrumental para a promoção de um debate rico e informado ou como um valor constitutivo da democracia, ou seja, um direito individual subjetivo que integra o direito politico de participação democrática. Examinada a primeira hipótese, sob perspectiva instrumental, a liberdade de expressão poderia sofrer restrições tendo por foco a melhoria do debate público. De outro lado, por um viés constitutivo, não se admitiria a restrição, pois a democracia tem por pressuposto a liberdade de expressão e não se limita à qualidade do debate público, mas a um direito universal de todos de trazer à esfera pública as suas convicções, ainda que possam ser consideradas equivocadas ${ }^{382}$.

O impacto da desinformação nas eleições é bastante relevante ${ }^{383}$. Nas propostas eleitorais a falsidade das informações ou o descomprimisso com as atividades ganham outro contorno segundo nossa perspectiva, pois não se está simplesmente a enunciar um fato falso, mas a realizar um compromisso, com natureza obrigacional. Enunciado um fato falso, o estado-juiz é chamado para impedir a continuidade ou reparar eventual dano. Atualmente, o compromisso que se mostrou falso não apenas não será cumprido, como a população não terá elementos institucionas bastantes para cotejar as propostas e seu cumprimento.

Falsidades prejudicam a compreensão de circunstâncias sociais, economicas, políticas e culturais que envolvem o rumo de um governo e em relacao ao qual o cidadao é chamado a escolher. A ausência de "fatos consensuais", que são fruto da ciência, inviabiliza qualquer debate racional relacionado a políticas públicas, bem como meios de avaliação de candidatos e suas propostas. Daí a razão pela qual o Estado deve zelar pela veracidade das informações colocadas no tabuleiro democrático.

Nas eleições nacionais de 2018 o Tribunal Superior Eleitoral criou a campanha "Esclarecimentos sobre Notícias Falsas", com o escopo de responder a boatos sofre denúncias de fraudes no processo eleitoral ${ }^{384}$. A partir desta iniciativa a Justiça Eleitoral criou o "Programa de Enfrentamento à Desinformação com foco nas Eleições 2020"385.

${ }^{382}$ GROSS, Clarissa Piterman. "Fake News e Democracia: discutindo o status normativo do falso e a liberdade de expressão". In: RAIZ, Diogo (coord.) FAKE NEWS: a conexão entre a desinformação e o direito. São Paulo: Thomson Reuters Brasil, 2018, pp. 164, 170-172.

383 O surgimento de novas tecnologias sempre geraram receios em relação a desequilíbrios nos pleitos eleitorais e manipulação do voto. Assim ocorreu com a redução dos preços do papel e o advento de máquinas impressoras, com as transmissões de rádio e televisão, com a veiculação de notícias na internet e, agora, com as redes sociais. RAIZ, Diogo. Fake News e Eleições. Op. Cit., p. 117.

384 Disponível em: <http://www.tse.jus.br/hotsites/esclarecimentos-informacoes-falsas-eleicoes2018/>. Acesso em 09/12/2019.

${ }^{385}$ Disponível em: <http://www.justicaeleitoral.jus.br/desinformacao/>. Acesso em 09/12/2019. 
Essas iniciativas denotam a preocupação da Justiça Eleitoral em impedir que os eleitores sejam enganados por informações falsas.

As democracias não funcionam bem sem uma base sólida, objetiva e confiável de estatística. Se uma população devidamente informada constitui pressuposto da democracia, conforme aponta Robert Dahl, logo, é dever do Estado, promover informação técnica acessível e de qualidade à cidadania para muní-la de elementos na oportunidade de escolha de candidatos para o próximo escrutínio ${ }^{386}$.

Não se trata de adentrar a esfera privada do cidadão visando controlar as informações que ele tem acesso, como na alegoria de Orwell na obra literária "1984", notadamente porque os cidadaos são livres para acessarem quaiquer fontes de informacao. Entretanto, cabe ao Estado, mediar um repositório de informações técnicas, aos quais individualmente o cidadã não teria acesso, ou como compilar os dados, para que tenha ele condições de verificar, em última análise, se as promessas realizadas em campanha foram ou vem sendo observadas na consecução de políticas públicas. Trata-se de prestigiar a accountability horizontal.

\subsection{Delineamentos para a criacao de órgão verificador do cumprimento de propostas eleitorais.}

Assentado que é dever do Estado tutelar a veracidade das informações públicas aos cidadãos, a bem da República e do regime democrático, passamos a responder, em relação às propostas eleitorais, alguns dos delineamentos trazidos por Jiménez Tello, que mencionamos no início do capítulo: quem avalia? Em que período é realizada a avaliação? E com base em quais indicadores, padrões de aferição?

Nossa proposta volta-se ao incremento de mecanismo jurídico de direito positivo, no dizer de Kelsen, sem apontar que tal adoção implicará em maior justiça ou qualquer outra apreciação moral, mas que conferirá maior transparência e eficácia na busca por qualidade democrática ${ }^{387}$.

386 DAHL, Robert A. Poliarquia. (Tradução: Celso Maduro Paciornick). São Paulo: Editora da Universidade de São Paulo, 2015, pp. 92-93.

387 "Direito e Justiça são dois conceitos diferentes. O Direito, considerado com distinto da justiça, é o Direito Positivo. É o conceito de Direito Positivo que está em questão aqui; e uma ciência do Direito positivo que está claramente distinguida de uma filosofia de justiça”. KELSEN, Hans. Teoria Geral do Direito e do Estado. (Tradução de Luís Carlos Borges). São Paulo: Martins Fontes, 3 Ed., 1998, p. 8. 
Quem poderia então avaliar se as propostas eleitorais estão sendo ou foram cumpridas? Antes de responder a essa questão vamos analisar aqueles órgãos a quem não seria conveniente a entrega da aferição das proposições.

O Poder Judiciário realiza ontologicamente o controle de legalidade dos atos administrativos, mas não o controle de mérito, ou seja, de conveniência e oportunidade sobre a prática de um determinado ato. Naturalmente caberá ao Poder Judiciário eventual disputa sobre a observância ou não do procedimento legal de apreciação do cumprimento das propostas, mas não o conteúdo da análise. A vedação ao controle de mérito sobre tal objetivo, a despeito de óbvia, de lege ferenda, deve estar expressa de forma bastante clara na lei que instituir o órgão de verificação, sob pena de valendo-se de princípios gerais e de uma conduta ativista, adentrar em questões meritórias, sem autorização legal.

Também não seria conveniente e quiçá eficaz que o Poder Legislativo ficasse a cargo de tal tarefa. Ao Legislativo se acomete a função de realizar o controle externo do Poder Executivo. Porém, aqui não se trata de um controle relacionado ao Poder em si, mas às escolhas políticas por ele realizadas em confronto com as propostas eleitorais. Se por mais não fosse, entre Legislativo e Executivo normalmente existe um liame governamental que poderia retirar a independência da análise de tais questões, de feição exclusivamente técnica. Não raro membros do Poder Legislativo presidem pastas do Executivo, bem como estabelecem bancadas de apoio ou oposição ao governo. Assim, caso tivessem que julgar o cumprimento das propostas, fatalmente a independência da análise estaria fortemente comprometida pelo viés utilitarista que poderia mover os parlamentares.

A realização da aferição por meio de institutos de estatística igualmente não seria conveniente. Como restou demonstrado, sobretudo no Brasil, órgãos públicos de estatística tem forte vínculo organizacional com o Poder Executivo, que tem flagrante interesse no resultado das apreciações. Além disso, o trabalho de avaliação das propostas muitas vezes implicará em apreciação jurídica, para que se possa identificar se a proposta podia ser cumprida diretamente pelo Poder Executivo ou demandaria o concurso de outro órgão, reserva de lei, análise quanto à suposta incidência de evento de força maior, etc. Não se descarta que os resultados estatísticos provenientes sejam considerados, mas a análise caberia ao órgão de verificação das propostas, conjuntamente com outras referências.

Por fim, as Cortes de Contas poderiam ser cogitadas para tal tarefa, até porque analisam a própria eficiência do gasto público e estariam habilitadas, em tese, a indicar se o governante se pautou por boas escolhas ao empregar a verba pública. Contudo, também a par de problemas relacionados à independência do órgão, cuja composição tem grande 164 
parte de seus membros indicados por outros poderes, as cortes de contas já possuem outras atribuições inerentes à verificação das contas públicas e da gestão do orçamento.

Diante disso, entendemos que a tutela administrativa das proposições eleitorais, sob o aspecto qualitativo e quantitativo do cumprimento das promessas eleitorais, deveria ficar a cargo de um órgão criado exclusivamente para esta finalidade, com características próprias. A tal órgão denominamos Agência de Verificação de Propostas Eleitorais, a quem doravante nos referiremos como AVPE, existente nos âmbitos federal e estadual ${ }^{388}$. O principal traço distintivo que levamos em consideração na escolha da natureza do órgão está relacionado à independência das agências, o que atende ao objetivo proposto para a verificação das proposições.

Importante lembrar que o artigo $1^{\circ}$ da Constituição Brasileira de 1988, assevera que o Brasil se constitui como Estado Democrático de Direito e entre seus fundamentos encontra-se a cidadania. Em seguida, no parágrafo único do referido artigo o constituinte afirma que todo o poder emana do povo, que o exerce nos termos da Constituicao, diretamente ou por representantes eleitos. Diante de tais fundamentos entendemos que a criação do referido órgão de controle, ligado ao escorreito exercício democrática e sua qualidade, tem natureza de órgão de Estado, e não de governo, pois não pode estar vinculado a quem titulariza o poder, especialmente porque é o titular quem deve ser escrutinado pelo órgão.

Trataremos brevemente de algumas sugestões para a estruturação da Agência, como natureza jurídica do órgão, vínculo jurídico dos servidores, modo de funcionamento e prazo para apresentação de relatórios. O delineamento pormenorizado de um órgão de tal natureza evidentemente exigiria um trabalho de maior fôlego. Todavia, nos parece essencial tratar de algumas características e elementos que devem ser levados em consideração na hipotética criação do órgão, sob pena de esvaziamento de suas finalidades e criação de órgão submisso e chancelador das atividades do Poder Executivo.

Quanto à natureza jurídica, o órgão poderia ser estruturado como autarquia de regime especial. Integrando a administração pública indireta, a autarquia dispõe de personalidade jurídica de direito público, é criada por lei, que prevê as competências

388 “'O vocábulo 'agência' é um dos modismos introduzidos no direito brasileiro em decorrência do movimento de globalização. Foi importado do direito norte-americano, onde tem sentido mais amplo que abrange "qualquer autoridade do Governo dos Estados Unidos, esteja ou não sujeita ao controle de outra agência, com exclusão do Congresso e dos Tribunais", conforme expressamente na Lei de Procedimetno Administrativo (Administrative Procedure Act)". DI PIETRO, Maria Sylvia Zanella. Direito Administrativo. Rio de Janeiro: Forense, 31 e.d rev. atual e ampl., 2018, p. 584. 
administrativas que lhe são próprias, sendo dotada de autonomia patrimonial, financeira e administrativa. Para efeitos deste trabalho não nos parece relevante descrever uma proposta de estruturação interna do órgão, como diretoria, presidência, conselho, formas de ascensão, etc.

Porém, conforme já assentado, e à vista dos relevantes interesses políticos que gravitariam em torno dos relatórios deste órgão, sua constituição deve se dar de tal forma que possa ser blindada de interesses externos, sobretudo diante de sua relevância políticodemocrática, com total autonomia financeira, administrativa e técnica. Em democracias menos maduras e mais instáveis como no Brasil, em que os conceitos de público e privado muitas vezes se entrelaçam de maneira pouco republicana, garantir a independência total do órgão não é só uma questão de qualidade de suas manifestações, mas sim de sobrevivência. A independência deve se dar na estrutura orgânica, e não na mera expectativa de que dirigentes nomeados pautem sua atuação de forma livre e imparcial.

A falta de independência orçamentária também serve de vetor que afasta o órgão de sua total insubmissão, primordial para um órgão cuja atividade consiste em apreciar o desempenho de outro órgão. O enforcamento orçamentário de um órgão pode torná-lo mais simpático ou antipático ao ente responsável pela liberação de seu orçamento. Desta forma, a receita poderia ser vinculada a um percentual sobre a arrecadação de determinado tributo, fixado um piso mínimo, garantindo o acesso a receitas. O orçamento apresentado pelo órgão consistiria em um plano quinquenal, de tal sorte que a aprovação em uma legislatura tivesse efeito apenas para a legislatura seguinte ${ }^{389}$.

Em relação aos servidores do órgão, os cargos públicos da agência seriam integralmente preenchidos por concurso público, vedada qualquer tipo de nomeação por outro órgão ${ }^{390}$. Aqui fazemos uma clara opção pela tecnocracia, como único meio de blindar a agência de captura pelo poder político. Experts são pessoas que tem um considerável conhecimento acerca de uma determinada matéria em comparação com outras pessoas $^{391}$. As análises estatísticas acerca do percentual de cumprimento de propostas eleitorais, fixadas de forma objetiva, devem ser realizadas por servidores que possuam expertise nas questões a eles subsumidas, e não estejam vinculados a qualquer tipo de

\footnotetext{
${ }^{389}$ Tal tentativa evidentemente não impede que o órgão sofra outros ataques de ordem política, como alterações legislativas que mudem a composição, estrutura, número de cargos, etc.

${ }^{390}$ Nosso argumento neste sentido é reforçado pela forma como são preenchidos os cargos de direção no IBGE e na Fundação SEADE no Estado de São Paulo, com grande influxo político na composição dos quadros.

${ }^{391}$ NICHOLS, Tom. The Death of Expertise. New York: Oxford University Press, 2017, p. 29. 166
} 
nomeação por órgãos externos, que possuam interesse no resultado dos relatórios ${ }^{392}$. A escolha da política pública cabe ao representante eleito, mas a aferição técnica quanto ao seu cumprimento dentro de balizas predeterminadas deve recair sobre o expert. Daí a importância em tentar diferenciar algumas questões que demandariam a apreciação por um especialista de outras em que se estaria diante de uma escolha político-democrática ${ }^{393}$. Refutamos a ideia de que o fortalecimento democrático encontra-se em oposição a um incremento de gestão técnica ${ }^{394}$. A dimensão política e a técnica (jurídico-instititucional) podem ser combinadas de maneira virtuosa. Compreender o funcionamento do governo representa observar o iter entre o impulso político e a ação governamental, com exposição à participação, ao contraditório social, às normas e controles ${ }^{395}$.

Nesse ponto, deve-se separar exatamente o que constituem questões técnicas de questões políticas. Quando o Tribunal de Contas rejeita as contas de um gestor público do Chefe do Poder Executivo, não há sentido em afastar os efeitos da rejeição com base em uma decisão política submetida à casa legislativa respectiva. A rejeição de contas é uma questão técnica e deveria corresponder a uma decisão terminativa em sede administrativa, com os efeitos previstos em lei. Submetê-la a convalidação pela casa legislativa não é, como pode parecer, prestigiar a democracia, considerando que lá se encontram os representantes diretamente eleitos pela população, mas sim desvalorizar a responsabilidade financeira e administrativa, conduzindo os gestores a fiarem-se mais na qualidade de relacionamento com os parlamentares do que com o cumprimento da lei. Por exemplo, imagina-se que uma pessoa não conseguiu quitar suas dívidas correntes. A inadimplência será atestada por órgão de cadastro de maus pagadores, conferindo um selo àquela pessoa de que se encontra em débito porque não cumpriu tempestivamente suas obrigações financeiras. Afastar tal consequência quando não se está em jogo a legalidade do

392 Sobre os problemas de captura de órgãos da administração pública em razão do excesso de cargos em comissão, ver: LEITE, Glauco Costa.Corrupção Política: Mecanismos de Combate e Fatores Estruturantes no Sistema Jurídico Brasileiro. Belo Horizonte: Del Rey, 2016, p. 123.

393، (...) quanto mais se busca o planejamento total, tanto mais a incompetência democrática deve ceder sem reservas à competência tecnocrática. SARTORI, Giovanni. A Teoria da Democracia Revisitada. Vol. 2. São Paulo: Ática, 1994, p. 227.

${ }^{394} \mathrm{O}$ incremento tecnológico, com a evolução da econômica familiar para uma economia de mercado, evoluindo para a industrialização, uma economia planificada, gera cada vez maior especialização e a necessidade de técnicos, o que alijaria o cidadão do protagonismo da sociedade industrial. "Tecnocracia e democracia são antitéticas: se o protagonista da sociedade industrial é o especialista, impossível que venha a ser o cidadão qualquer. A democracia sustenta-se sobre a hipótese de que todos podem decidir sobre tudo. A tecnocracia, ao contrário, pretende que sejam convocados para decidir apenas aqueles poucos que detêm conhecimentos específicos.” BOBBIO, Norberto. O Futuro da Democracia. (Trad. Marco Aurélio Nogueira). São Paulo: Paz e Terra, 2000, p. 46.

${ }^{395}$ BUCCI, Maria Paula Dallari. Fundamentos para uma Teoria Jurídica das Políticas Públicas. São Paulo: Saraiva, 2013, p. 35. 
procedimento implica em dar ao mercado uma informação falsa, afastando o devedor dos efeitos legais da inadimplência.

Entretanto, o Supremo Tribunal Federal, no ano de 2016, decidiu que é exclusivamente da Câmara Municipal a competência para julgar as contas de governo e as contas de gestão ${ }^{396}$ dos prefeitos, cabendo ao Tribunal de Contas auxiliar o Poder Legislativo municipal, emitindo parecer prévio e opinativo, que somente poderá ser derrubado por decisão de $2 / 3$ dos vereadores ${ }^{397}$. E ainda, em caso de omissão do Poder Legislativo na apreciação das contas, o parecer do Tribunal de Contas não gera a inelegibilidade prevista em lei ${ }^{398}$. Não se pretende aqui analisar os pressupostos da decisão à luz da Constituição Federal de 1988, mas apenas o quanto uma análise técnica é prejudicada por uma opção política. Com a devida vênia, saber se houve gastos em desconformidade com a lei que comportam reprovação das contas de gestão, constitui questão técnica, de matemática financeira, e não opção política. Se em razão da rejeição das contas devem ou não existir efeitos e se estes devem ser submetidos à casa legislativa para referendo a questão é outra. Portanto, há que ser feita uma distinção, pois a aprovação ou reprovação das contas deveria caber exclusivamente ao órgão técnico. Não se trata de desprestigiar as casas de leis, mas de permitir que elas façam as opções políticas que ontologicamente lhe cabem e não as técnicas, que demandam conhecimento adequado. Permitir que questões como tais sejam definidas pelo poder político representa despistar a cidadania, afastando-se de accountability, para que ela não identifique de forma clara a má-gestão financeira, tendo como palavra final que as contas foram "aprovadas" pelo parlamento.

Portanto, a agência não terá por tarefa apenas a produção de estatísticas. As estatísticas representam uma relevante ferramenta para a parametrização de indicadores,

396 As "contas de governo" são as contas anuais que demonstram a atividade financeira do ente federado no exercício findo. Nestes casos, a competência é do Congresso Nacional para a apreciação das contas do Presidente da República (CF, artigo 49, IX e 71, I) e mercê do paralelismo constitucional, a competência para apreciar as contas do prefeito cabe à Câmara dos Vereadores. Em ambos os casos, o Tribunal de Contas atua apenas como órgão auxiliar, emitindo parecer consultivo, de modo que o "julgamento" pelo Poder Legislativo tem natureza política. De outro lado, o julgamento das "contas de gestão", de seu turno, corresponde à apreciação das contas dos administradores e responsáveis pelo emprego de recursos públicos, em que são proferidas decisões administrativas com critérios técnicos, pelo Tribunal de Contas, podendo ser aplicadas sanções como, por exemplo, multas (CF. art. 71, II).

${ }^{397}$ Recursos Extraordinários (REs) 848826 e 729744, julgados sob o regime da repercussão geral.

398 Artigo 1º inciso I, alínea "g”, da Lei Complementar 64/1990. São inelegíveis aqueles que "tiverem suas contas relativas ao exercício de cargos ou funções públicas rejeitadas por irregularidade insanável que configure ato doloso de improbidade administrativa, e por decisão irrecorrível do órgão competente, para as eleições que se realizarem nos oito anos seguintes, contados a partir da data da decisão, aplicando-se o disposto no inciso II do artigo 71 da Constituição Federal”. 
mas profissionais de outras áreas são essências para o para que o órgão cumpra o objetivo a que se propõe, como um corpo de economistas, administradores e advogados. O corpo jurídico, formado por procuradores concursados, para além de realizar a defesa do órgão, teriam por incumbência auxiliar na verificação da exequibilidade jurídica das propostas e das escusas para descumprimento, bem como tomar as medidas cabíveis para que os auditores possam ter acesso a dados que não se encontram disponíveis e são necessários às avaliações.

Além disso, uma vez desligados do órgão por qualquer razão, os membros auditores, cargos de maior escalão na agência, não poderiam integrar outros órgãos da administração pública de qualquer esfera ou candidatarem-se a cargos políticos, cumprindo período de quarentena por cinco anos. A medida, que necessariamente deve estar prevista na lei que institui a autarquia, visa impedir que investidas externas de agentes de outros órgãos interessados em pareceres positivos ou negativos em relação ao cumprimento das propostas venham a ser negociados em troca de cargos públicos. Poderia se questionar se a restrição a qualquer esfera não seria excessiva, podendo se limitar apenas à área de abrangência? Por exemplo, um integrante de uma AVPE Estadual poderia, uma vez exonerado, ingressar em órgão da administração pública federal. A limitação a qualquer cargo nos parece necessária para tutelar ao máximo a integridade do órgão e impedir que o oferecimento de cargos ocorra sobre base territorial distinta, longe das luzes das críticas.

Em relação a seu funcionamento, o órgão colherá todas as informações que entender pertinentes, podendo requisitá-las de outros órgãos. A lei estabelecerá o prazo em que a agência deverá se manifestar apresentando relatórios. Algumas observações parecem pertinentes em relação ao tema. Em primeiro lugar, não seria conveniente que o parecer ocorresse apenas após o término do mandato. Um governante poderia ser reconduzido ao cargo, estendendo um mandato de quatro para oito anos e no início do segundo mandato a publicação do relatório demonstrar um pífio cumprimento de metas, informação que poderia se mostrar relevante no pleito em que se apresentou à reeleição. Ademais, acaso prevista na própria lei alguma consequência jurídica para o caso de cumprimento de metas abaixo de determinado parâmetro, igualmente restaria prejudicada a penalização, que se tornaria incompatível com a eleição que deu origem ao segundo mandato.

Desta forma, nos parece que o ideal seria a emissão de dois pareceres a cada mandato, um após o terceiro ano de mandato e outro parecer que abrangesse todo o período da administração. Os pareceres deveriam ser apresentados dentro de 3 meses após o término do ano-exercício de análise. O primeiro parecer, após três anos de mandato, teria o 
condão de orientar os eleitores para as próximas eleições, desenhando um quadro bastante preciso do que foi feito nos três anos de administração. O segundo parecer delinearia o retrato completo do que representou a administração em relação às promessas e compromissos de campanha.

Publicados os pareceres, teria sido cumprida a função de dar transparência quantitativa e qualitativa ao atendimento das proposições, bem como o caráter democrático de permitir que o povo reconduza referido governante ciente de suas realizações no governo que chegou ao termo final.

Por fim, cabe a pergunta já formulada por Bobbio: quem controla o controlador? ${ }^{399}$. Um órgão que detenha um poder político implícito de tal relevância, com elevado grau de independência, apto a impor a um governo a pecha de descumpridor de compromissos demanda controle, como todo e qualquer ente público. Entendemos que na hipótese o controle deveria ser exercido pelo Ministério Público, órgão que também dispõe de importante grau de independência funcional, administrativa e financeira, e seus membros não detém, institucionalmente, participação político-eleitoral na qualidade de candidatos $^{400}$.

\subsection{Do processo de análise das propostas e da emissão de parecer acerca do cumprimento.}

Na política, naturalmente, a tarefa de avaliar conjuntamente as propostas eleitorais se mostra desafiadora na medida em que um governante poderia se limitar a realizar propostas em apenas uma área, com o intuito de, nesta seara, empenhar-se para ao final do mandato demonstrar alto grau de cumprimento. Esse comportamento lhe conferiria o selo de cumpridor de propostas, talvez de forma diferente de outros candidatos que apresentassem propostas em diversas áreas, colhendo bons resultados em algumas e reveses em outras.

399 “Quem controla os controladores?" Se não conseguir encontrar uma resposta adequada para esta pergunta, a democracia, como advento do governo visível, está perdida. Mais que de uma promessa nãocumprida, estaríamos aqui diretamente diante de uma tendência contrária às premissas: a tendência não ao máximo controle do poder por parte dos cidadãos, mas ao máximo controle dos súditos por parte do poder". BOBBIO, Norberto. O Futuro da Democracia. Op. cit., p. 43.

${ }^{400}$ Há uma exceção no sistema brasileiro. No caso dos membros do Ministério Público que ingressaram antes do advendo da Constituição Federal de 1988, é admitida a eletividade. Atualmente o artigo 128, II, inciso "e", veda o exercício de atividade político-partidária por membros do Ministério Público. 
Outra questão interessante seria se as propostas deveriam ter pesos distintos em razão da grandeza ou relevância social. Uma proposta que prometesse a criação de um milhão de empregos deveria pontuar mais do que o encaminhamento de proposta de lei que altere a licença paternidade de 5 para 10 dias? A resposta seria positiva se tivessemos em foco a repecursão econômica e o crescimento do Produto Interno Bruto. Entretanto, o papel da AVPE não seria de identificar de forma valorativa o que é mais ou menos relevante para o desenvolvimento econômico do país, mas apenas realizar uma verificação técnica quanto ao cumprimento efetivo, total ou parcial, das propostas realizadas em campanha, apresentando o resultado final, por meio de relatório que circunstancie tais situações.

Assim, a legislação deveria prever o peso das avaliações por setor, elegendo áreas fundamentais e o percentual a que corresponderão na análise final. A título de exemplo, poderiam ser apontadas cinco áreas fundamentais: 1) educação e ciência; 2) saúde e saneamento; 3) economia (que abrangeria trabalho, emprego, previdência); 4) infraestrutura e sustentabilidade; e por fim, 5) "outros". Cada qual poderia ser responsável por $20 \%$ da análise final quanto ao cumprimento das propostas dos candidatos.

Como nem todas as áreas são identificáveis e há uma mutação temporal nos interesses, uma designação para "outros” se justifica. Há algum tempo atrás as questões ambientais despertavam menor interesse do que hoje. É provável que dentro de alguns anos as questões relacionadas à tecnologia digital, inteligência artificial e internet ganhem ainda mais importância.

Retomando as modalidades de propostas eleitorais que formulamos no capítulo anterior, a AVPE deverá identificar as propostas como ilegais, legais inexequíveis ou legais exequíveis, sejam elas objetivas ou subjetivas, conforme classificação que realizamos no Capítulo 3, item 6, acerca das modalidades de proposições eleitorais. A realização de uma proposta cujo cumprimento escape da esfera de competência do proponente, inexequível, portanto, deverá ser reputada como "descumprida”. Isso coloca sobre o candidato o ônus de conhecer as atribuições do cargo para o qual se apresenta, para que não prometa algo que sabe que se encontra fora de sua esfera de competência. Citamos um exemplo deste caso no capítulo anterior, que toca ao candidato ao governo de estado federativo no Brasil que promete a implementação de pena de morte, o que constitui matéria que compete exclusivamente à União.

Passando ao procedimento de análise das propostas vislumbramos que o rito deveria seguir as seguintes etapas, naturalmente previstas em lei: 1) procedimento de reunião das propostas; 2) apresentação do quadro final das propostas; 3) apresentação de 
escusas ou elementos que denotem o cumprimento das propostas pelo governante; 4) análise de cumprimento das propostas, escusas e parece final; 5) recurso administrativo.

$\mathrm{O}$ procedimento tem início com a reunião das propostas realizadas durante $\mathrm{o}$ período de campanha eleitoral. Em sede administrativa, em um prazo até 60 dias da posse do chefe do Poder Executivo, auditores da Agência compilarão todas as proposições realizadas para a formação do quadro geral de propostas sujeitas a análise durante o mandato. Para que seja observado o contraditório, neste período tanto o partido político do candidato vitorioso, agora governante, como dos demais partidos poderão apresentar documentos, áudios, vídeos, etc., que comprovem as propostas realizadas visando a formação do quadro geral. Da decisão que apresentasse o quadro final de propostas haveria recurso administrativo para o órgão superior da própria Agência. Como apontado no Capítulo 3, as proposições objeto de análise são todas aquelas que constem do programa eleitoral de governo do candidato. Mas não apenas estas. Devem ser abrangidas também outras manifestações realizadas durante o período oficial de campanha, veiculados por qualquer meio, até a data da eleição, que desbordam do programa eleitoral de governo e incluem entrevistas, programa eleitoral gratuito, material oficial de campanha distribuído, debates, manifestações em redes sociais, etc. Valendo lembrar que é possível que antes da eleição, seja em primeiro ou segundo turno, o candidato retifique as propostas, valendo para efeito de verificação a última manifestação antes do pleito eleitoral. A retificação deve ser inequívoca, manifestando-se o candidato de forma expressa de que está a mudar a sua proposta outrora formulada.

O procedimento de reunião das propostas se mostra relevante na medida em que não se limita à análise ao programa eleitoral de governo apresentado à justiça eleitoral. Assim, havendo a possibilidade de as propostas realizadas por outros meios desbordarem do programa, se faz necessário um procedimento para a sua reunião, que culminará com a publicação do quadro geral de proposições realizadas pelo candidato.

Em igual linha de importância, seria no processo de reunião das propostas que se poderia, desde já, identificar a natureza de cada proposição, realizando filtragem com o objetivo de identificar as propostas "legais inexequíveis" e "legais exequíveis", e dentre as proposições legais exequíveis, aquelas que podem ser aferidas, por corresponderem a “propostas objetivas" ou por representarem "propostas subjetivas", sejam elas "subjetivas meramente programáticas" ou "subjetivas propriamente ditas", como melhor descrevemos no Capítulo anterior no item 3.6. 
Aproximadando-se da data de realização das avaliações, no prazo de 60 dias anteriores à emissão do parecer, o governante poderia apresentar as justificativas que entendesse pertinentes acerca do não cumprimento de determinadas propostas ou, de outro lado, material que visasse a corroborar o cumprimento das proposições.

Por fim, os auditores da AVPE realizariam a análise das escusas, que trataremos um pouco mais à frente, bem como emitiriam o parecer final de cumprimento, indicando o percentual de implemento em casa uma das áreas, e do governo como um todo. Da referida decisão caberia recurso administrativo para a própria AVPE.

Importa mencionar novamente que este mero exercício de estruturação do órgão tem por objetivo a demonstração da viabilidade da proposta, não se pretendende afirmar de forma peremptória que o órgão avaliador das propostas deveria ser constituído exatamente como propomos ou com as finalidades que apresentamos. Como mencionado, a estruturação de órgão desta natureza poderia ser objeto de pesquisa exclusiva para tal fim, diante das vicissitudes envolvidas. De outro lado, não nos limitamos a apenas mencionar que a avaliação seria realizada por uma agência a ser criada, pois a identificação de algumas das dificuldades e virtudes do órgão são decorrentes exatamente do exercício criativo da instituição, justificando, aí sim o tema da nossa tese, o controle da verificação das propostas eleitorais.

\subsection{Possibilidades de escusa ao cumprimento da proposição.}

A análise das políticas públicas sobre o viés da chamada "policy analysis", que para além da teoria política clássica, isola o poder como tema central, compreendendo o poder a partir de sua permeabilidade com as diversas variáveis que explicam o fenômeno da ação governamental. A denominada "policy" corresponde a uma rede de decisões e ações que alocam valores e esforços. O processo decisório não é analisado apenas de forma instrínseca, mas também em relação às iniciativas políticas à vista de problemas concretos, alternativas, avaliações e resultados ${ }^{401}$. Por tal razão, mesmo as proposições que se adequem a todos os critérios elencados como pressupostos de exequibilidade $\mathrm{e}$ exigibilidade, no curso do mandato, poderão ser objeto de alegação de "escusa de

401 BUCCI, Maria Paula Dallari. Fundamentos para uma Teoria Jurídica das Políticas Públicas. São Paulo: Saraiva, 2013, pp. 105-106. 
descumprimento" por parte do governante, ao argumento que em razão de condições exógenas seu governo restou impossibilitado de cumprir a promessa realizada.

Não há como se furtar à necessidade de análise das justificativas para que se identifique se o governante não cumpriu a proposta, de um lado por falta de vontade política, imperícia, mera demagogia eleitoral ${ }^{402}$ ou, de outro lado, por fatores externos que realmente não podem ser atribuídos ao governante.

Naturalmente existe uma zona cinzenta em que podem se situar algumas situações. Isso, porém, não serve de desitímulo para que paulatinamente se desenvolva um sistema apto a identificar tais conjunturas. Por exemplo, se um governador estadual promete a construção de um conjunto habitacional em uma determinada localidade de um município durante sua campanha eleitoral, afirmando de pronto, que utilizará recursos exclusivamente estaduais. Porém, após os estudos iniciais, observa-se que o terreno é absolutamente impróprio para construção, o que impossibilita a edificação no local. Em outra possibilidade se imagina que verba que daria ensejo a tal construção adviesse do governo federal e que não pode ser repassada a vista de contingenciamento, ou seja, por fato não atribuível ao próprio governante estadual.

Como a AVPE deveria agir nestes casos? Reputar que o governante simplesmente não cumpriu a promessa ou reconhecer a impossibilidade de cumprimento por fato externo? Os casos parecem se adequar mais à hipótese de "descumprimento escusável", por se vislumbrar que o fato impeditivo não teve o concurso do proponente e a especificidade técnica de nível elevado, notadamente no primeiro caso, não lhe podia ser exigida. Já no segundo caso, a escusabilidade decorre da vinculação da proposta à origem da receita.

Há propostas que compreensivelmente estão sujeitas a diversos fatores como, por exemplo, compromisso com redução ou aumento da taxa de juros. Diante de sua vinculação com outros instrumentos econômicos como inflação, déficit de contas, câmbio e taxa juros no exterior, uma proposição desta natureza poderia ser realizada como compromisso, mas o governante poderia tentar demonstrar a ocorrência de causa excludente de exigibilidade. Assim, o candidato a Presidente da República promete

402 “(...) uma máxima que não posso deixar tornar-se pública sem ao mesmo tempo frustar minha própria intenção - que deve permanecer secreta se deve ter êxito e para a qual não posso me declarar publicamente sem que por isso seja levantada indefectivelmente a resistência de todos contra meu propósito não pode vir esta contraposição necessária e universal, por conseguinte a priori inteligível de todos contra mim de nenhum outro lugar a não ser da injustiça com que ela ameaça a todo". KANT, Immanuel. A Paz Perpétua (Trad. Marco Zingano). Porto Alegre: L\&PM Editores, 2011, posição 785-790. 
baixar uma taxa de juros anual que está na faixa de $10 \%$ para $6 \%$ ao ano no seu primeiro ano de governo. Contudo, em tal período, a taxa de juros em outros países de importantes mercados foi elevada, a inflação interna dobrou, o câmbio desvalorizou-se e guerras civis deflagradas em países do Oriente Médio elevaram o preço do barril do petróleo. Exigir a implementação impositiva da queda dos juros neste cenário não seria adequado. A questão que se segue é: a alteração de taxas no exterior é um evento imprevisível ou aquele que se compromete com alteração da taxa deveria levar em conta tal questão? Nesta hipótese a leitura do cenário externo e o risco de um compromisso neste sentido não pode alforriar o proponente, que a bem da verdade, arriscou-se ao fazer compromisso desta natureza, em que é cediço que existe a interdependência de diversos outros fatores.

Quando tratamos do vínculo político-eleitoral entre representantes e representados, visando um reforço democrático do liame, sugerimos uma aproximação com a figura jurídica de um contrato em que o candidato é o proponente e a cidadania o oblato. Ao tratar neste momento das hipóteses de escusas face ao eventual descumprimento dos compromissos, pretendemos nos valer de algumas figuras do direito administrativo, especificamente na seara dos contratos administrativos em que é facultado à Administração a rescisão unilateral dos contratos.

É certo que há uma dificuldade nesta analogia, pois o candidato eleito, agora governante, é o chefe da Administração Pública, de modo que o exercício de transformálo de proponente em contratado gera naturais dificuldades ontológicas, já que no polo contratante, não mais estaria apenas cidadania, mas também o interesse público da Administração, consubstanciado na responsavidade democrática. Desta forma, reiteramos que pretendemos realizar apenas uma aproximação das figuras e não uma sobreposição.

Além disso, trataremos de outras escusas, que nos parecem cabíveis, para debate das justificativas quanto ao descumprimento das propostas: reserva legal, falta de orçamento por ausência de repasse de verbas, decisão judicial que impede o cumprimento da proposta, utilização de instrumento de democracia direta que altere a propostas, "fato do príncipe", teoria da imprevisão e fatos imprevistos.

Passemos a analisar tais situações.

4.8.1 Cumprimento de proposta que demande aprovação de projeto de lei ou emenda constitucional. 
Caggiano adverte que a positivação constitucional de novas direitos com textos repletos de preceitos abertos, não-executórios, impõe ao Poder Executivo esforço adicional para a criação e instalação de programas que gerem efetividade aos direitos, mas ao mesmo tempo onera também o Poder Legislativo, a quem cabe complementar as normas constitucionais de eficácia limitada por meio de edição normativa. Contudo, tais dificuldades técnicas do ponto de vista executório não podem servir de justificativa para que sejam ignoradas as competências constitucionais, ou no dizer da autora promovam "a demolição da ideia de rigidez constitucional" ${ }^{403}$.

Nesta linha de ideias, se a matéria objeto da proposta está coberta pelo manto da reserva legal, a rigor o Chefe do Poder Executivo não poderia ser imputado como descumpridor do compromisso em decorrência da não aprovação da norma a que vinculada a proposição, na medida em que o cumprimento escapa de competência institucional do cargo que titulariza.

Entretanto, nestes casos em que se demanda a aprovação de peça legislativa, o Chefe do Poder Executivo deverá demonstrar que houve o encaminhamento do projeto de lei ou emenda constitucional ao parlamento ou, uma vez aprovado, não o vetou. Se o projeto não foi votado ou veio a ser rejeitado, realmente não há como imputar responsabilidade ao governante ${ }^{404}$.

Logo, proposta que dependesse de projeto de lei que não veio a ser aprovado, mas cujo projeto foi encaminhado pelo Poder Executivo, ou por ele expressamente encampado, em caso de apresentação por terceiros, não permitiria concluir que a promessa foi descumprida. Tampouco permitiria autorizar a conclusão de que foi cumprida, porque a lei era apenas um pressuposto para que houvesse a execução da promessa. Assim, em casos como este, a avaliação seria de "impossibilidade de verificação" de cumprimento por causa alheia à vontade do administrador, e tal indicador deverá ser afastado do contingente de propostas cujo percentual de cumprimento será refletido no parecer final.

403 CAGGIANO, Monica Herman S. "Democracia x constitucionalismo: um navio à deriva?" In: Cadernos de Pós-Graduação em Direito: estudos e documentos de trabalho / Comissão de Pós-Graduação da Faculdade de Direito da USP, São Paulo, n. 1, 2011, p. 17 e 20.

${ }^{404}$ Não se descarta a possibilidade de que o Chefe do Executivo realize uma manobra política consistente em encaminhar o projeto de lei à casa legislativa e, ao mesmo tempo, orientar sua base de apoio a votar contrariamente ao projeto. Tal expediente é utilizado quando o Chefe do Poder Executivo pretende reduzir seu desgaste com a opinião pública aparentando que almejava a aprovação da lei quando, em verdade, atua politicamente para sua desaprovação. 


\subsubsection{Proposta que depende de recursos financeiros advindos de outra esfera.}

Quando a proposta tiver por pressuposto recursos oriundos de outra esfera é indispensável que ao realizar o compromisso o candidato informe de onde virá a receita $^{405}$. Neste caso, ou seja, tendo afirmado que a verba, em montante específico ou aproximado viria de determinada esfera de governo, ou de parceria, caso a verba não venha a ser recebida, por fator alheio à vontade do governante, não se poderia cogitar de descumprimento. Da mesma forma que no caso anterior de cumprimento, também não poderíamos cogitar, devendo a proposta ser excluída do rol de análise para efeito de percentual de cumprimento e taxada como "impossibilidade de verificação". A situação se altera caso o governante tenha dado causa ao não recebimento da verba, por descumprir parte dos requisitos necessários para seu recebimento. Nesta hipótese a proposta deverá ser reputada como não cumprida, sendo sopesada para o relatório final.

Caso o proponente não indique a origem da receita, o descumprimento da proposta redundará em anotação como "proposta descumprida", não se podendo valer de escusa diante do não recebimento de verba de outro ente.

\subsubsection{Cumprimento de proposta obstado por decisão judicial.}

Se o cumprimento de uma proposta é inibido em razão de decisão judicial, o governante poderá ser responsabilizado como se descumprido tivesse a proposta? Por exemplo, se um candidato se compromete a privatizar uma determinada empresa pública e, após iniciar o procedimento de desestatização, decisões judiciais liminares impedem a privatização da empresa.

\footnotetext{
${ }^{405}$ A tarefa de avaliar a execução de políticas públicas é complexa, conforme já apontamos alhures, uma vez que a própria alocação de meios os recursos orçamentários abrangem não apenas as receitas como também créditos fiscais, empréstimos públicos, cessão de bens e serviços, recursos humanos e materiais, etc. Para aferir índices de medida do tamanho do setor público Bustos Gilbert realiza uma classificação tripartite entre gastos, ingressos e outros indicadores da atividade do poder público. Os gastos públicos podem ser divididos em agregados, que oferecem uma ideia do tamanho do estado, como a comparação do gasto total com o PIB e Renda Nacional, enquanto os desagregados correspondem à análise de como o setor público realiza o gasto, ou seja, a cada determinada quantia despendida, quanto é gasto como folha de pagamento, investimento (inversión). Os ingressos também são divididos em agregados e desagregados, sendo que aqueles correspondem, por exemplo, à pressão fiscal, ou seja, o total de impostos dividido pelo PIB e estes como, a guisa de referencia, a definir a carga tributária para um determinado grupo de contribuintes. Outros índices são separados entre aqueles que medem o desequilíbrio das contas públicas e os que buscam identificar em que medida o setor público participa na produção total da economia. GISBERT, Antonio Bustos. Curso Básico de Hacienda Pública. Pamplona: Editorial Aranzadi, 4. E.d., 2017, pp. 29-31.
} 
A primeira impressão é que não parece importar a razão pela qual judicialmente se entendeu que o processo de privatização não poderia prosseguir naquele momento, já que o administrador se viu obstado por um órgão externo. Entretanto se poderia perquirir se a decisão judicial decorreu de falta de competência do administrador na formulação do edital de privatização. Neste caso, já que o governente - e sua equipe - teriam dado causa à obstacularização do procedimento de privatização ao não empregar as formalidades devidas, não seria prudente conferir o selo de "impossibilidade de cumprimento" para a proposta, mas sim de "proposta descumprida". Imaginemos um governante que não tem a intenção de cumprir uma proposta de privatização, mas que gostaria de atribuir o descumprimento a outra razão. Poderia ele iniciar um procedimento sabidamente equivocado, ciente de que haveria questionamento judicial, para posteriormente alegar que o descumprimento ocorreu em decorrência da autação do Poder Judiciário.

Para evitar que situações como essa ocorram, o corpo jurídico da AVPE deveria analisar o conteúdo das decisões judiciais para observar se o óbice identificado judicialmente pode ou não ser atribuído ao governante. Se a ele for atribuída culpa, a proposta seria consierada "descumprida". Ao revés, não identificada culpa por parte do promitente, seria apontada como caso de "impossibilidade de cumprimento".

\subsubsection{Instrumento de democracia direta que altere a conteúdo da proposta.}

Impedir que o governante alterasse ou mesmo reconhecesse estar equivocado em relação a uma proposta implicaria em imobilizá-lo durante todo o mandato, tornando-se refém do próprio programa, ignorando-se não apenas a mutabilidade das situações fáticas que ensejaram determinadas propostas, bem como eventuais estudos que demontrassem que os resultados pretensamente obtidos com uma determinada proposta não seriam atingidos ou haveria outros meios mais eficazes para tanto. Desta forma, não se poderia afirmar que o governante se afastou da responsividade democrática, pois como já mencionamos em outras oportunidades, a eleição representa o início do diálogo, de assunção de compromissos entre o governante e a cidadania, mas que prossegue durante o exercício do mandato.

Se o objetivo do presente trabalho é a efetividade da busca pelo cumprimento das propostas, já que atualmente não há exigibilidade alguma, engessar totalmente o governo a ponto de obrigá-lo a cumprir todas as propostas, vedadas retificações, redundaria em flagrante excesso. $\mathrm{O}$ argumento da ausência de controle seria utilizado para gerar um 
controle excessivo. Assim, estando o governante diante de proposta que gostaria de alterar, três opções se colocariam.

A primeira seria simplesmente reconhecer que se equivocou em relação à proposta, que melhor analisando o tema, não a cumpriria por entender que ela não atenderia ao interesse público. Neste caso, a despeito da honestidade da explicação, constaria no relatório da AVPE como "proposta descumprida". Afinal, a aferição correponde aos compromissos realizados em campanha eleitoral.

Outra alternativa, especialmente se o governante tivesse a intenção de evitar que a proposta fosse taxada como "descumprida", poderia representar a submissão da alteração proposta à manifestação popular, por plebiscito ou outros instrumentos de exercício de democracia direta, de modo que caso a população, por maioria, se mostrasse contrária à concretização da proposta, naturalmente tal proposição não mais poderia ser imputada como "descumprida", na medida em que a própria coletividade teria exonerado o governante do cumprimento. E caso a cidadania confirmasse o desejo de efetivação da proposta, não restaria outra alternativa ao governante entre cumprir a proposta, aqui evidentemente pressupondo que não dependesse de outros órgãos ou de reserva legal, ou então valer-se da hipótese prevista no parágrafo anterior, confirmando as razões pelas quais descumpriria a proposta, com a rubrica de "promessa descumprida".

Acaso a legislação autorize, poderia haver uma terceira possibilidade, que consistiria em representação junto ao Poder Legislativo para que o governante fosse autorizado a alterar o compromisso no curso do mandato, mediante um quórum de maioria amplamente qualificada, visando preservar as propostas previamente realizadas.

A guisa de exemplo temos o caso da flexibilização do porte de armas no Brasil. Na eleição presidencial de 2018, o então candidato Jair Bolsonaro se comprometeu a promover ações para tornar mais fácil o acesso ao porte de armas ${ }^{406}$. Entretanto, em pesquisa divulgada um dia antes da posse do Presidente Jair Bolsonaro, pesquisa revelou que $61 \%$ da população era contrária à flexibilização da posse de armas ${ }^{407}$. Neste caso, o Presidente poderia realizar um plebiscito sobre o tema e, confirmado o resultado da pesquisa no escrutínio, estaria exonerado do dever de cumprimento. A proposta seria avaliada pela AVPE como “descumprimento escusável”.

406 Disponível em: https://congressoemfoco.uol.com.br/eleicoes/maioria-dos-presidenciaveisdefende-desarmamento-veja-a-posicao-de-cada-um/. Acesso em 13/03/219.

${ }^{407}$ Disponível em: <https://g1.globo.com/politica/noticia/2018/12/31/para-61-dos-brasileiros-possede-armas-de-fogo-deve-ser-proibida-diz-datafolha.ghtml> . Acesso em 07/06/2019. 


\subsection{5 "Fato do príncipe", teoria da imprevisão e fatos imprevistos.}

$\mathrm{Na}$ esfera administrativa, os contratos devem preservar o equilíbrio econômicofinanceiro da avença visando compatibilizar o interesse público da Administração contratante e do interesse do particular contratado. Celso Antonio Bandeira de Mello afirma que podem ocorrer diferentes hipóteses de agravos econômicos aptos a abalar a estabilização contratual. São eles: a) agravo econômico decorrente de sobrecargas decididas pelo contratante no uso de seu poder de alteração unilateral do contrato; b) agravo econômico resultante de medidas tomadas pelo poder contratante, sob titulação jurídica diversa da contratual, o chamado "fato do príncipe"; c) agravo econômico decorrente de fatos imprevisíveis produzidos por forças alheias às partes contratantes, a denominada "teoria da imprevisão"; d) agravo econômico proveniente das chamadas "sujeições imprevistas", dificuldades materiais que as partes não podiam prever e que fazem pesar uma grave e anormal carga para o contratado; e) agravo econômico resultantes da inadimplência da administração contratante ${ }^{408}$.

Esse arcabouço jurídico inerente às hipóteses de manutenção do equilíbrio econômico-financeiro dos contratos administratos poderia, em alguma medida, ser adaptado para os compromissos decorrentes de propostas eleitorais, ainda que estes não tenham conteúdo econômico. Não se pretende, à evidência, fazer uma transposição de institutos, mas realizar uma aproximação, na medida em que não existe um regime jurídico próprio das proposições eleitorais. Desta forma, os apontamentos adminitrativistas trazidos não pretendem dissecar os institutos, mas simplesmente deles acercar-se.

Dentre as modalidades mencionadas, duas não teriam qualquer aplicação. A primeira, o agravo econômico decorrente de sobrecargas decididas pelo contratante no uso de seu poder de alteração unilateral do contrato, porque ao candidato promitente não seria dada prerrogativa de alterar unilateralmente a proposta, sob pena de, por via transversa, continuar a legitimar a demagogia eleitoral, se ao candidato for franqueada a revogação unilateral de seu compromisso. A mutabilidade da proposta poderia ocorrer por meio da utilização de instrumento de democracia direta, como apontado no item anterior, ou mediante a chancela do Poder Legislativo, mediante quórum amplamente qualificado. Em

\footnotetext{
${ }^{408}$ MELLO, Celso Antônio Bandeira de. Curso de Direito Administrativo.. São Paulo: Malheiros, $34^{\mathrm{a}}$ ed., ref., e atual, 2019, pp. 679-681. 
quaisquer das hipóteses, não se admite a mutação unilateral da proposta realizada pelo próprio proponete.

A última hipótese, agravo econômico resultante da inadimplência da administração contratante, também não teria aplicabilidade porque aqui discutiremos a inadimplência do governante, outrora proponente, e não da Administração, ainda que esta tenha aquele por representante.

Quanto às demais modalidades, nos parece possível compatibilizar as proposições eleitorais com o "fato do príncipe", a "teoria da imprevisão" e as "sujeições imprevistas".

O "fato do príncipe" consiste no ato ou fato da autoridade pública estatal contratante que realiza uma determinação, positiva ou negativa, em caráter geral e imprevisível, que onera excessivamente ou impede a execução do contrato, reclamando a compensação dos prejuízos suportados pelo contratado ${ }^{409}$. Emerge de seus elementos a existência de uma determinação de caráter geral e, portanto, não específica sobre o objeto da contratação, traço que o distingue do denominado "fato da administração". É necessário, ainda, que o ato tenha sido praticado pela autoridade contratante e não por autoridade pública de outra esfera. Por fim, imperioso que o fato ou ato seja imprevisível e o gravame deve ser de tal grandeza que torne impossível ou dificulte excessivamente seu cumprimento.

Trasladado o instituto para as proposições eleitorais, o "fato do príncipe" representaria a conduta do governante que pratica ato de sua esfera de competência, não relacionado com o objeto de determinada proposta eleitoral, mas que venha a tornar o objeto da prestação, ou seja, a promessa de campanha, senão impossível, extremamente gravosa. Logo, a conclusão é que o governante não poderia se valer de um ato por ele próprio praticado, ainda que fora do objeto da proposta eleitoral, para sustentar a impossibilidade de cumprimento ou sua onerosidade excessiva, pena inclusive de se aplicar o brocardo nemo auditur propriam turpitudinem allegans ${ }^{410}$. Por exemplo, um candidato ao Poder Executivo Federal afirma em campanha que fará credenciamento de médicos estrangeiros para prestar serviços em áreas remotas do país. Entretanto, uma vez eleito, encaminha ao Congresso Nacional, projeto de lei para a criação da carreira de médico de Estado, para atendimento nas áreas mais remotas e carentes, incluindo na lei dispositivo que veda a contratação de médicos de outras nacionalidades. Na hipótese, tem-se que o

${ }^{409}$ GASPARINI, Diogenes. Direito Administrativo. São Paulo: Saraiva, 1995, $4^{\circ}$ ed - rev. e ampl., p. 394.

${ }^{410}$ Ninguém pode se valer da própria torpeza. 
governante praticou ato de sua esfera de competência - o encaminhamento de projeto de lei - não relacionado especificamente com a proposta - que tratava de credenciamento dos médicos estrangeiros - mas torna impossível o cumprimento da proposta, caso o Congresso acolha o projeto de lei apresentado sem alterar tal disposição.

A teoria da imprevisão funda-se na existência de fatos inesperados, anômalos, que não podem ser prenunciados pelos contratantes e tornam o cumprimento da avença excessivamente onerosa, autorizando a revisão do contrato, em observância à chamada cláusula rebus sic stantibus. É indispensável, portanto, que a interferência seja imprevisível, anormal, e não guarde qualquer relação com o comportamento das partes, seja de natureza dolosa ou culposa ${ }^{411}$.

Enquadram-se nesta categoria as hipóteses de caso fortuito e força maior ${ }^{412}$. Ambos são eventos externos à Administração, estranhos à vontade do governante, imprevisíveis e inevitáveis, que implicam na impossibilidade absoluta de cumprimento da proposta ${ }^{413}$. Porém, enquanto o caso fortuito decorre de um acidente de causa desconhecida ou de uma conduta humana, como guerras ou greves, a força maior advém das forças da natureza, como raio, tempestade, neve, etc ${ }^{414}$. Destaca-se o requisito da impossibilidade absoluta de implemento, o que o diferencia da existência de maior dificuldade para seu cumprimento, que decorre da álea econômica, que tem os mesmos pressupostos, quais sejam, acontecimento externo à obrigação, imprevisível e inevitável, gerando grande desequilíbrio econômico, mas que não impede a execução do contrato, apenas tornando-o mais oneroso $^{415}$. Nestes casos, a Administração aplica a teoria da imprevisão para rever as cláusulas financeiras do contrato e viabilizar a continuidade contratual. Por exemplo, a queda de barragem de represa gerando grave inundação poderia exonerar o promitente do cumprimento das propotas.

${ }^{411}$ GASPARINI, Diogenes. Direito Administrativo. Op. Cit., p. 391.

${ }^{412}$ No Brasil, a Lei de Licitações (Lei Federal $n^{\circ}$ 8.666/93) em seu artigo 78, inciso XVII, assevera que constitui motivo para a rescisão contratual a "ocorrência de caso fortuito ou de força maior, regularmente comprovada, impeditiva da execução do contrato".

${ }^{413}$ DI PIETRO, Maria Sylvia Zanella. Direito Administrativo. Rio de Janeiro: Forense, 31 e.d rev. atual e ampl., 2018, p. 320.

${ }^{414}$ DINIZ, Maria Helena. Curso de Direito Civil Brasileiro. São Paulo: Saraiva, $2001,15^{\circ}$ ed. rev. v.7., p, 97.

${ }^{415}$ Na Primeira Guerra Mundial, diante da alta dos preços do carvão, as concessionárias de gás francesas não conseguiam continuar com a exploração mediante as tarifas então contratadas. O Conselho de Estado Francês reconheceu a necessidade de revisão, uma vez que o cumprimento nos moldes anteriormente acertados conduziria a empresa à ruína. DI PIETRO, Maria Sylvia Zanella. Direito Administrativo. Op. Cit., p. 319. 
Sujeições ou fatos imprevistos são dificuldades de ordem material que não podiam ser previstas antes do compromisso, tornando mais gravosa ou impossível sua implementação ${ }^{416}$. Na esfera de nossa pesquisa, por exemplo, um candidato formula uma proposta específica de construção de uma escola em um determinado terreno que já pertence ao ente que pretende presidir. Contudo, alçado ao cargo, após estudos iniciais descobre-se que o terreno apresenta contaminação química que inviabiliza qualquer construção. Não havia como exigir que o candidato tivesse tal informação ao tempo da campanha, logo, o descumprimento não poderia implicar em uma "promessa descumprida".

Trazendo estes conceitos para a proposta apresentada, o ideal é que algumas destas possibilidades sejam inclusive já previstas na própria lei que institui a AVPE, o que preveniria, em alguns casos, a análise de escusas. Por exemplo, caso a arrecadação do governo seja inferior a um determinado percentual, em comparação com o valor registrado no ano anterior, o governante ficaria automativamente isento do escrutínio pela AVPE. Dispositivo desta natureza igualmente impediria que redução de arrecadação inferior à baliza legal desse ensejo a alegações de força maior, entendendo-se que flutuação da arrecadação dentro de um determinado patamar legal constituiria um evento, malgrado inevitável, previsível.

Na questão trazida anteriormente acerca da proposta de Presidente da República que se compromete com determinada redução de taxa de juros, nos parece que a flutuação de taxas no exterior não corresponde, por si só, a um evento imprevisível. Portanto, para que o promitente se desonere da proposta, teria que realizá-la de forma condicionada, por exemplo: "reduzirei os juros a $2,5 \%$ por cento, desde que a taxa não varie mais do que $7 \%$ por cento, por exemplo, nos Estados Unidos e na Zona do Euro". Outra possibilidade apta a justificar o reconhecimento de caso fortuito seria a comprovação de que a alteração dos juros no exterior ocorreu fora dos parâmetros previsíveis. Por exemplo, nos Estados Unidos entre 2008 e 2018 a taxa de juros variou de 0 a 2,5\%. Logo, uma elevação para acima de $7 \%$ ao ano, poderia gerar grande impacto na taxa de investimento externo que aporta no Brasil. Embora a elevação por si só não seja elemento bastante para reconhecimento da força maior, pode servir de base para análise da queda de arrecadação. Se a flutuação da taxa era um evento previsível, a elevação para $7 \%$ não era, à vista do histórico do país.

\footnotetext{
${ }^{416}$ MELLO, Celso Antônio Bandeira de. Curso de Direito Administrativo. Op. Cit., pp. 680-681.
} 
Em outro exercício, um candidato a presidente de um país que integre a zona do Euro poderia realizar propostas com fundamento nesta integração econômica. Se houver dissidência de um ou mais países, o governante poderia alegar e demonstrar que houve alteração substancial no bloco, gerando reflexos na arrecadação do país, e por consequência, inviabilizando a execução de propostas.

\subsection{Das sanções.}

Tratamos sobre a necessidade de se buscar sancionamento para o descumprimento das propostas eleitorais no item 3.8 do Capítulo anterior. Agora passamos a entrever, de lege ferenda, algumas possibilidades de sancionamento. A aplicação de sanções de caráter jurídico demanda previsão normativa a esse respeito. Logo, quaisquer hipóteses que venham a ser discutidas nesta seara em decorrência do conteúdo do relatório da AVPE só tem aplicação se previstas em lei.

É certo que a apresentação de relatório que importe na demonstração qualitativa e quantitativa do cumprimento das propostas tem efeito político, e já implica, por si só, em sanção, ao revelar à cidadania de maneira institucional, que o governante não está cumprindo com os compromissos assumidos. Entretanto, acreditamos que a efetividade demande a previsão de sancionamento. Duas consequências que bem se adequariam à insuficiência de resultado são a vedação à reeleição e a impossibilidade de utilização (ou limitação) de uso de verba publicitária.

A responsabilização deve recair apenas sobre Chefe do Poder Executivo e de seu vice, exceto se pensado um sistema em que as propostas do partido político se tornassem vinculantes. Aplica-se aqui a teoria da unicidade da chapa de candidatura, até porque as propostas são realizadas pela chapa, ainda que veiculadas por um ou outro integrante da composição. Isso é importante para deixar claro que uma proposta realizada por um vicecandidato vincula a chapa, exceto se retificada posteriormente antes da eleição. Deste modo, havendo divergência de propostas entre os membros da chapa, deve prevalecer a proposta do cabeça de chapa, ou seja, o candidato à chefia do cargo ${ }^{417}$.

417 Na eleição presidencial brasileira de 2018, o então candidato à vice-presidência Hamilton Mourão teceu críticas ao $13^{\circ}$ salário. Embora não se tratasse de proposta expressa de supressão do direito, ainda que pelo encaminhamento de proposta de emenda à Constituição, é certo que Jair Bolsonaro, à época candidato à presidência, tratou de rechaçar tal possibilidade. Disponível em: < https://exame.abril.com.br/brasil/no-twitter-bolsonaro-rebate-criticas-de-vice-mourao-ao-13o-salario/>. Acesso em 28/02/2019. 
Uma consequência legal prevista pelo desatendimento de determinado percentual das propostas eleitorais poderia ser a limitação de utilização de verba com publicidade, não cumprido determinado percentual das propostas no curso do mandato. Ainda que a publicidade não seja do candidato, é evidente que quanto mais se promovem feitos de uma administração, na mesma proporção são vinculados implicitamente ao governante e ao partido. Assim, impedir ou limitar a utilização de verba publicitária implicaria em incentivar o administrador a se empenhar para o cumprimento de suas propostas. Portanto, acaso, por exemplo, a AVPE registrasse cumprimento global inferior a 50\% das propostas, a verba publicaitária poderia ser reduzida na mesma medida.

A lei poderia prever também que um desempenho administrativo pífio redundaria em hipótese de inelegibilidade. Por exemplo, um administrador que não cumprisse nem mesmo $30 \%$ de suas propostas no primeiro triênio poderia ser impedido de concorrer à reeleição ou vir a ser nomeado para cargos públicos comissionados, de qualquer esfera, após o término da gestão.

As mesmas vozes que se elevam contra a Lei da Ficha Limpa para afirmar que ela limita a liberdade democrática ao impedir que o povo opte livremente por um candidato que, a despeito de incidir nas hipóteses de inelegibilidade, seria um melhor administrador, argumentariam contrariamente à limitação por nós sugerida. Na essência o argumento seria o mesmo, de que a lei estaria impedindo, de forma indevida, a liberdade do povo de escolher um candidato, apesar de ele não ter apresentado desempenho razoável. Neste caso, a mesma resposta poderia ser dada em ambos os questionamentos. O povo, por meio do Poder Legislativo, democraticamente eleito, teria anuído com a referida limitação, ao autorizar de forma mediata, a edição da lei com tal previsão.

\subsection{Da revisão do mérito dos pareceres pelo Poder Judiciário.}

No Brasil, mercê do princípio da inafastabilidade da jurisdição, insculpido no artigo $5^{\circ}, \mathrm{XXXV}^{418}$, da Constituição Federal, não há como se negar o acesso ao Poder Judiciário para questionamentos relacionados a procedimentos administrativos, como as decisões da AVPE, cuja criação sugerimos. A mesma situação ocorre na Espanha, cuja Constituição,

\footnotetext{
${ }^{418}$ Artigo $5^{\circ}$, XXXV - a lei não excluirá da apreciação do Poder Judiciário lesão ou ameaça a direito.
} 
no artigo 106.1, prevê o controle judicial do poder regularmentar e da legalidade da atividade administrativa $^{419}$.

Contudo, a judicialização de mérito do parecer da agência quanto ao cumprimento das propostas potencialmente pode esvaziar a finalidade sancionatória proposta, como os casos de suspensão do parecer ou impedimento para que ocorra sua publicação tempestivamente. Uma publicação de resultados que possa servir de bússola ao eleitor perderá tal finalidade se apenas vier a lume após o pleito eleitoral. Além disso, se o Poder Judiciário pretender realizar reparos quanto à apreciação do órgão, como, por exemplo, questionando os critérios adotados, submetendo os dados para realização de perícia judicial ou alteração de índices e estatísticas, igualmente estará esvaziado o objetivo da agência, que poderá ser capturado pela jurisdição.

$\mathrm{Na}$ verdade, a garantia de independência quanto às decisões de mérito da AVPE estaria mais assegurada se nosso sistema fosse dual, inspirado no sistema francês, em que a par da jurisdição comum, a jurisdição administrativa teria poderes para dirimir conflitos envolvendo a Administração Pública, com força de coisa julgada, impossibilitando-se, assim, questionamentos na esfera judicial ${ }^{420}$.

De qualquer forma, com o objetivo de normativamente fortalecer as decisões administrativas do órgão, a lei poderia prever que não caberia a revisão dos critérios adotados pelos auditores da agência para aferição do cumprimento das propostas. Malgrado tal não impeça o acesso ao Poder Judiciário, poderia servir de contenção a interpretações que avançassem ao mérito, visando a efetividade teleológica dos pareceres, filtrada por um processo de self-restrain do Poder Judiciário.

Nesta linha de ideias, as lições de Caggiano são precisas, especialmente ao advertir que o Poder Judiciário, escudado na guarda da democracia, não pode pretender que as interpretações hermenêuticas neoconstitucionalistas assumam uma postura "descompromissada com o princípio da segurança jurídica"421. Vale dizer, a bem da efetividade, da garantia de direitos fundamentais, não pode o hermeneuta olvidar-se das regras legítimas e democraticamente colocadas, exatamente com o escopo de limitar o exercício do poder.

\footnotetext{
${ }^{419}$ Artigo 106. 1. Los Tribunales controlan la potestad reglamentaria y la legalidade de la actuación administrativa, así como el sometimiento de ésta a los fines que la justifican.

${ }^{420}$ DI PIETRO, Maria Sylvia Zanella. Direito Administrativo. Op. Cit., p. 591.

${ }^{421}$ CAGGIANO, Monica Herman S. "Democracia x constitucionalismo: um navio à deriva?". Op. Cit., pp. 15-16. 
Em relação ao parecer acerca do cumprimento das propostas, o Poder Judiciário deverá ser acionado apenas quando o "procedimento" legal de verificação das propostas não for observado, ou seja, quando as etapas de verificação não seguirem o regramento legal. Por exemplo, quando a agência emitir uma manifestação antes do término do prazo para que o administrador apresente justificativas para o descumprimento ou não solicitar a apresentação de determinados documentos. 


\section{SISTEMA DE TUTELAS DAS PROPOSTAS ELEITORAIS} GERADORAS DE DIREITO COLETIVO - causas de inelegibilidade, os "contratos políticos" e a cláusula "elegível a direito".

Claudio Lembo recorda que no Estado Democrático de Direito os governantes são escolhidos pela cidadania e, ambos, governantes e governados, se submentem à lei que foi legitimamente concebida ${ }^{422}$. Nesta linha, no capítulo anterior apresentamos uma proposta, de lege ferenda, que tem por escopo oferecer maior transparência entre as proposições de campanha e sua efetiva implementação, instituindo previsão legal de sancionamento para algumas hipóteses de descumprimento em que governantes descumprem os compromissos assumidos ao tempo do pleito eleitoral.

Passamos agora a um grau distinto e mais problemático do tema, pois para além da transparência e do próprio sancionamento ao promitente descumpridor, analisaremos três outras situações, aprofundando o vínculo eleitoral entre representante e representado, bem como dele decorrendo consequências jurídicas.

A primeira hipótese implica em elevar a promessa de cumprimento integral de mandato eleitoral à hipótese legal de inelegibilidade, de modo que, o promitente que venha a descumprir o compromisso de exercer integralmente o mandato fique impedido de concorrer a outro cargo.

A segunda consiste na possibilidade de que sejam celebrados "contratos políticos" entre os candidatos e a cidadania, prevendo consequências positivas e negativas a depender do desempenho apresentado. Note-se que aqui as consequências adviriam do próprio "contrato", ou seja, do compromisso assumido pelo candidato, e não como decorrência direta de previsão legal.

Por fim, a terceira hipótese representa a possibilidade de eventualmente franquearse a tutela judicial direta em relação ao que fora compromissado pelo governante. Nesta hipótese o Poder Judiciário passa a cumprir uma função mais ativa, pois se enquanto nos demais casos cabia ao Poder Judiciário apenas atestar a regularidade do procedimento, mercê do cumprimento ou não das propostas, aqui a tutela judicial específica implementaria diretamente a promessa descumprida. Tal possibilibilidade ocorreria apenas

\footnotetext{
${ }^{422}$ LEMBO, Cláudio. A pessoa: seus direitos. Barueri: Manole, 2007, p. 155.
} 
mediante prévia e voluntária submissão da proposta pelo candidato, alçando-a como “cláusula elegível a direito".

Os desafios aqui, sobretudo nas duas últimas hipóteses, certamente são maiores do que em relação à criação da Agência de Verificação de Propostas Eleitorais, na medida em que são tomadas medidas à revelia do governante, cabendo identificar as possibilidades da referida intervenção e seus efeitos.

\subsection{Causa de inelegibilidade - promessa de cumprimento integral de mandato.}

No Brasil não é incomum que alguns candidatos realizem o registro de propostas de campanha perante os cartórios extrajudiciais de notas. Tal conduta tem viés exclusivamente político e populista, e pretende fazer crer que, mercê da cartorariedade, a proposta seria um compromisso exigível tanto quanto é para os particulares que registram compromissos de compra e venda e outras avenças. Ocorre que o descumprimento não acarreta consequências jurídicas aos proponentes, as propostas eleitorais de campanha registradas em cartório equivalem rigorosamente a um nada jurídico, representando puro instrumento de demagogia eleitoral.

A promessa de cumprimento integral do mandato é um dos elementos que o corpo eleitoral leva em consideração no momento em que escolhe o Chefe do Poder. A nosso ver, deveria existir previsão legal expressa de causa de inelegibilidade para aquele que se compromete a não se candidatar antes do término do mandato, caso eleito. Nesta hipótese, caso venha a participar de outro pleito eleitoral, haveria expressa vedação legal. Para tanto, no Brasil, bastaria inserir uma alínea no artigo $1^{\circ}$, inciso I, da Lei das Inelegibilidades (LC $n^{\circ}$ 64/90), para indicar que aquele que se compromete por escrito a cumprir integralmente o mandato, fica impossibilitado de concorrer a qualquer outro cargo, antes do termo final do cargo para o qual fora eleito. A medida auxiliaria a melhor selecionar, motivar e controlar a atividade política.

Trata-se de compromisso deveras relevante, cujo descumprimento e ausência de sanção serve apenas para desvalorizar a confiança pública na política. O que não se pode admitir é que um compromisso tão importante com os eleitores de uma determinada circunscrição eleitoral possa ser ignorado sem qualquer consequência. Alguns talvez argumentem que o sancionamento representaria uma limitação à liberdade democrática e que o corpo eleitoral teria livre-arbítrio para, ele próprio, sancionar o candidato pelo descumprimento da proposta, em regular exercício de accountability vertical. Ocorre que o 
vínculo do candidato é com o colégio eleitoral que o elegeu, e este extrato eleitoral deve ser respeitado. No Capítulo 3 citamos que em 2014 e 2016, respectivamente, José Serra e João Doria, eleitos para a chefia do Poder Executivo no município de São Paulo, descumpriram as promessas de cumprimento integral do mandato, vindo a concorrer a outros cargos antes do término do mandato municipal.

Uma maneira de exonerar, porém, o mandatário de tal obrigação apenas poderia ocorrer se o mesmo colégio eleitoral que o elegeu, em exercício de instrumento de democracia direta, mediante consulta, anuísse com o descumprimento do compromisso, alforriando o mandatário da obrigação assumida.

$\mathrm{Na}$ mesma medida, mas alterando-se o poder em foco, entendemos que deveria existir expressa vedação legal à assunção de cargo no Poder Executivo a parlamentares eleitos, por duas razões. A primeira é que o mandato conferido pela cidadania deferiu poderes para o exercício do cargo de parlamentar, o que deve reclamar cumprimento. A segunda é que o parlamento por natureza exerce função fiscalizadora do Poder Executivo, que fica comprometida com a licença de seus membros para exercerem funções no órgão que devem institucionalmente fiscalizar.

\section{2 "Contratos políticos" sob a perspectiva da democracia contratual.}

Duverger apontava que a observância das normas decorria ou do medo da incidência de alguma sanção, seja ela de qualquer natureza, moral, econômica, política, ou pelo valor à própria regra, ou seja, a norma é observada porque se compreende que é boa para a convivência civil ${ }^{423}$.

As regras de direito são regras sociais em relação às quais a autoridade pública determina que a inobservância implica na incidência de uma sanção jurídica. Assim, o cidadão que não paga seus impostos terá seu nome incluído no rol de maus pagadores, sofrerá um processo judicial e poderá ter seus bens apreendidos para a quitação do débito. Portanto, a norma desprovida de sanção, é ineficaz.

Um contrato, segundo a teoria geral do direito, corresponde ao concurso de declarações de vontades, de dois ou mais indivíduos, segundo uma forma prescrita ou não defesa em lei, dirigidas a certa conduta. Uma das partes realiza uma oferta e, com a

423 DUVERGER, Maurice. Institutions Politiques et Droit Constitutionnel - Les grands système politiques. Paris: Presses Universitaires de France, $12^{\circ}$ Ed., 1971. t. 1, p. 14. 
aceitação da outra, considera-se celebrado o contrato. Portanto, as partes possuem vontades paralelas, alinhadas com o objeto contratual $^{424}$. Embora tal consideração aparentemente se adeque exclusivamente ao Direito Civil, entendemos ser possível transportar tais conceitos para o Direito Público, em sua feição eleitoral, especialmente em relação às propostas de campanha, ainda que o vínculo estabelecido entre mandante e mandatário possua natureza político-eleitoral, que decorre diretamente da $1 \mathrm{ei}^{425}$. Alguns estudiosos sustentam que os resultados tendem a ser melhores se as metas são negociadas e não simplesmente impostas de forma unilateral. Além disso, melhores resultados advêm quando são concedidas determinadas flexibilidades tendo metas a alcançar como contrapartida ${ }^{426}$. As propostas eleitorais equivalem a metas em relação às quais o candidato se vale para "negociar" sua contratação diante da cidadania.

Em síntese, o questionamento que queremos trazer é: poderia o candidato propor um verdadeiro "contrato político", com suas propostas eleitorais, de modo que o eleitorado aceitasse a proposta na condição de oblato ao elegê-lo? Responder afirmativamente implicaria em dizer que se trataria de um retorno ao sistema de representação do mandato imperativo $^{427}$ ?

Existe distinção entre ser obrigado a atuar de acordo com as determinações do mandante durante o curso do mandato, como no caso do mandato imperativo, e a hipótese que escudamos, no sentido de que o mandante deve se empenhar para cumprir os compromissos assumidos antes mesmo da assunção ao cargo executivo. Trata-se de um instrumento que objetiva a complementação do processo eleitoral com sua integração ao processo democrático responsivo.

Hans Gersbach, professor da Universidade de Zurique, dedicou grande parte de sua pesquisa aos "contratos políticos". Ele sugere o controle do comportamento político de governantes por meio de "contratos políticos" que definem recompensas e punições a vista

${ }^{424}$ KELSEN, Hans. Teoria Geral do Direito e do Estado (Tradução de Luís Carlos Borges). São Paulo: Martins Fontes, $3^{\circ}$ ed.,1998, pp. 204-205.

425 “(...), os direitos políticos, assim definidos, não diferem essencialmente dos direitos do Direito Civil. Apenas, esses direitos classificados como políticos têm maior importância na formação da ordem jurídica que os do Direito Civil”. KELSEN, Hans. Teoria Geral do Direito e do Estado. Op. Cit., p. 338.

${ }^{426}$ PACHECO, Regina Silva. "A agenda da nova gestão pública”. In: Loureiro, Maria Rita; Abrucio, Fernando; Pacheco, Regina. Burocracia e Política no Brasil: desafios para a ordem democrática no século XXI. Rio de Janeiro: Editora FGV, 2010, p. 201.

${ }^{427}$ No mandato imperativo o representante age em nome do representado e sobre sua orientação, ou seja, sua conduta é delegada e a representação se dá nos exatos limites das instruções do representado. Para um melhor delineamento acerca do mandato representativo: PITKIN, Hanna Fenichel. El Concepto de Representacion. Op. Cit., pp. 41. 
do cumprimento dos compromissos. A democracia eleitoral passaria a ser suplementada por esses "contratos políticos", que correspondem aos compromissos assumidos pelos candidatos antes das eleições.

$\mathrm{O}$ autor apresenta uma metáfora comparando o candidato político a alguém que almeja uma vaga no mercado de trabalho. $\mathrm{O}$ candidato à vaga se inscreve para a posição aberta e apresenta suas habilidades para o preenchimento da posição. O empregador avaliará o candidato que se mostrar mais adequado para a função e celebrará com ele um contrato, em que serão descritas as obrigações do empregado, seus deveres, bem como a obrigação do empregador, de pagamento da contraprestação pecuniária. Superado um determinado período, o empregador avaliará a performance do empregado, podendo mantê-lo ou demiti-lo. O candidato a cargo político, da mesma forma, propõe uma agenda de trabalho e destaca suas qualidades, afirmando ser a pessoa mais preparada para implementar as propostas. Uma vez eleito passará a receber um "salário", que inclui não apenas dinheiro, mas também privilégios, prestígio e autoridade com vistas à implementação de sua agenda política. Ao final do termo, poderá submeter seu nome para "nova contratação" ou ser rejeitado pela cidadania ${ }^{428}$.

O candidato teria, então, a faculdade de apresentar "contratos políticos". Note-se que se trata de uma faculdade, não havendo qualquer imposição neste sentido. Assim, se de um lado o candidato tem a vantagem de não se submeter às consequências do descumprimento do "contrato" ao não o propor, de outro, pode ser acusado por seus concorrentes de não confiar em sua habilidade para cumprir as promessas ou serem elas fruto de demagogia eleitoral. Assim, a formulação de propostas no bojo de contratos políticos poderia revelar credibilidade por parte dos candidatos em um cenário competitivo.

Embora nossa pesquisa se limite às propostas formuladas por candidatos a cargos executivos, Gersbach também admite a possibilidade de "contratos políticos" em eleições legislativas formulados por partidos políticos em que, por exemplo, são identificados

${ }^{428}$ Naturalmente a alegoria apresenta aos menos três diferenças, como lembra Gersbach. O voto igualitário é o único instrumento para a chegada ao poder e o corpo eleitoral que escolhe um candidato apresenta discordâncias em relação às políticas públicas propostas pelos candidatos e a seu resultado. Por fim, a separação dos poderes impõe limitações ao exercício da administração pelo governante, de modo que os resultados "não dependem exclusivamente de sua habilidade e esforço". GERSBACH, Hans. Redesigning Democracy. Zürich: Springer, 2017, p. 3. 
partidos com os quais a agremiação pretende ou não pretende formar uma coalisão para governar $^{429}$.

Entre as punições sugeridas pelo autor diante de performance deficitária, encontram-se a redução de salários, implicações no direito a pensão, perda de privilégios, como motorista, veículos de categoria inferior, etc. Além disso, também são sugeridas punições relacionadas ao mandato, como impossibilidade de concorrer a um segundo mandato, término prematuro de seu mandato, exigência de maior votação para a reeleição, o que o Gersbach denomina "higher bars for incumbents", ou seja, "barreiras mais elevadas para os titulares do mandato".

Neste caso, considerando-se que o candidato à reeleição quase sempre goza de maior possibilidade de sucesso do que quem concorre fora do governo, o candidato a um primeiro exercício, certo de que implementaria sua agenda, se comprometeria desde já, a assumir que precisaria de um percentual maior de votação para ser reconduzido em um segundo mandato. Isso implicaria, em tese, em um esforço ainda maior no primeiro mandato para conseguir os votos extras de que necessitaria para a reeleição. Por fim, a última consequência poderia ser a restrição de acesso de seu partido político ao fundo partidário $^{430}$.

De outro lado, as recompensas a serem oferecidas pelos candidatos proponentes poderiam ser também vinculadas a remuneração e regalias, ou seja, a face oposta das limitações supra, como possibilidade de majoração de vencimentos, acesso a títulos honoríficos ou assento permanente em conselho de estado. Em relação ao mandato, uma performance excepcional poderia conferir mais um ano de mandato, por exemplo. Por fim, o autor cita a possibilidade de premiação por governar com foco no futuro. É comum que políticos não se empenhem em políticas de longo prazo, pois seus resultados poderiam exigir muitos anos para serem identificados, sem trazer a contraprestação eleitoral almejada, ou seja, o reconhecimento popular transformado em votos em um próximo pleito. Por isso, uma forma de fazer com que políticos se voltem mais para as futuras gerações, seria dar valor distinto exatamente ao voto destas gerações ${ }^{431}$.

O autor propõe, em síntese, quatro tipos de contratos políticos aos quais denomina: “contrato limite para reeleição", "contrato de curta duração com ou sem benefício

\footnotetext{
${ }^{429}$ Idem, Ibidem, p. 7.

${ }^{430}$ GERSBACH, Hans. Redesigning Democracy. Op. Cit., pp. 7-8.

${ }^{431}$ Idem, Ibidem,p p. 9-10.

194
} 
monetário", "contrato de longa duração com ou sem benefício monetário" e "contrato para futuras maiorias" ${ }^{432}$.

Não se pretende analisar quais seriam as alterações constitucionais necessárias para que se pudessem implementar tais modalidades no Brasil ou em outros países, mas apenas conhecê-las de forma mais próxima.

O primeiro, denominado "contrato limite para reeleição", consiste na criação de barreiras eleitorais mais elevadas para o candidato à recondução em cotejo com aqueles que almejam a assunção ao cargo. Alguns estudos indicam que é mais difícil ser eleito do que ser reconduzido ao cargo em processo de reeleição ${ }^{433}$. Gersbach propõe uma inversão, tornar a reeleição mais difícil do que a eleição, autorizando os candidatos a oferecerem "barreiras mais elevadas” para a reeleição. Por exemplo, antes da primeira eleição, o candidato se compromete que somente poderá ser reeleito se atingir um percentual superior a $50 \%$, algo como $55 \%$ ou $60 \%$ do percentual de votos válidos. Esse comportamento reduziria a vantagem daqueles que concorrem à reeleição. A essa modalidade o autor denomina de "vote share contract" "34. O candidato aparentemente aumenta sua credibilidade na medida em que aceita se submeter a um patamar mais exigente para a reeleição, como se dissesse que tem tamanha certeza de que seu governo cumprirá os compromissos assumidos, que se submeterá a um patamar mais elevado para que possa se sagrar vencedor do segundo certame. De outro lado, a sociedade, em tese, aumentaria as chances de um governo responsivo, ciente da maior exigência de votos para recondução.

Um ponto a ser observado é que aqui o candidato faz um compromisso em relação ao segundo mandato, sem ter ingressado na Administração, ou seja, sem conhecer o funcionamento da máquina pública. Daí deriva a denominação "vote share contract without signaling of competence", que em tradução livre corresponde a "contrato de voto compartilhado sem sinalização de competência". Outra modalidade volta-se à possibilidade daquele que concorre à reeleição e, portanto, já conhece o funcionamento da Administração, oferecer um contrato com maiores exigências. Como aponta Gersbach, uma vez empossado, o titular não teria nenhuma razão para impor sobre si um encargo eleitoral superior. Entretanto, ao tempo da candidatura à primeira eleição, um compromisso

${ }^{432}$ GERSBACH, Hans. “Contractual Democracy”. In: Law \& Economics 823 (2012), pp. 824-828.

${ }^{433}$ Sobre o tema ver o nosso artigo Reeleição Presidencial no Brasil e seus Reflexos na Qualidade Democrática e no Combate à Corrupção. in: HIROSE, Regina Tamami (org.). Carreiras Típicas de Estdo Desafios e Avanços na Prevenção e no Combate à Corrupção. Belo Horizonte: Editora Fóum, 2019, pp. 134146.

${ }^{434}$ GERSBACH, Hans. Redesigning Democracy. Op. Cit., pp. 37-38. 
com um desempenho eleitoral superior para a recondução poderia impulsionar a primeira candidatura $^{435}$. Cabe anotar, de outro lado, que exigências desse jaez também poderiam eventualmente estar previstas em lei, e não necessariamente decorrer de um "contrato político".

Passemos a algums exemplos para ilustrar tais situações. Na campanha presidencial norte-americana no ano de 1988 o então candidato George H.W. Bush prometeu, na convenção do partido republicano, que não iria criar novos impostos ${ }^{436}$. Assim, se descumprida fosse a regra e houvesse o status de "contrato" como condicionante para a reeleição, estaria vedada a candidatura a novo pleito. Entre nós, na mesma linha, em questão que tomou bastante espaço na eleição presidencial brasileira de 2018, o candidato Fernando Haddad, afirmou que não concederia indulto ao ex-presidente Lula, que fora condenado criminalmente. Portanto, se Haddad fosse eleito e indultasse o ex-presidente, seria impedido de concorrer a novo mandato, caso existisse o referido "contrato político", em que tal cláusula estivesse vinculada ao franqueamento à reeleição.

A segunda modalidade representa o "contrato de curta duração com ou sem benefício monetário". O grau de cumprimento das propostas dá ensejo a uma recompensa que pode ou não ter caráter monetário como, por exemplo, uma variação existente nos salários dos governantes de acordo com a performance apresentada. De outro lado, pode haver uma sanção monetária ou não, no caso de um desempenho ruim, como autorizar a antecipação das eleições. Aqui também se incluem eventuais compromissos de não se coligar com determinados partidos. O descumprimento também poderia dar origem a consequências como redução do acesso ao fundo partidário. Note-se que nesta modalidade os efeitos ocorrem ainda sob a égide do mandato em curso.

Similar a esta modalidade é o "contrato de longa duração com ou sem benefício monetário". Neste caso, o benefício ocorrerá após a conclusão do mandato, e verificado o cumprimento da meta. Esta modalidade visa mitigar o problema de não apresentação de propostas que dependeriam de mais um mandato para serem executadas. Como o candidato pretende ser reconduzido ao cargo, fazer promessas que exigiriam mais de um mandato para serem efetivamente implementadas, com apresentação de resultados, tenderiam a ser evitadas pelos candidatos, que buscariam formar um projeto de propostas que pudesse ser

435 "If he promises to accept reelection only if he is reelected with a higher, pre-defined vote percentage, he is percived as willing to put so much effort into his first term in office that the voters will reward him with more votes than his incumbency advantage alone would yield". Idem, Ibidem, p. 55.

436 "Read my lips: no new taxes".

196 
apresentado ao final do mandato como instrumento para a reeleição ou candidatura a cargo distinto. Este cenário prejudica as bases de desenvolvimento democrático e daí a proposta do autor para que o candidato, antes da primeira eleição, ofereça um "contrato político" que se refira ao segundo mandato, e apenas em caso de reeleição o contrato teria efeito. $\mathrm{O}$ proponente vincula a possibilidade de participação em um segundo certame ou seus vencimentos, ao atingimento de determinados parâmetros, como o índice de desemprego abaixo de determinado percentual ${ }^{437}$. Assim, caso ele atinja o parâmetro estabelecido na área que ele próprio colocou no topo na hierarquia de suas propostas, poderá concorrer ao segundo mandato e ser avaliado pelo restante de suas políticas pela cidadania. Outro benefício poderia ser vinculado à redução do desemprego ou aprimoramento do equilíbrio orçamentário, em que o governante reeleito poderia receber um ano adicional no novo mandato ou, caso se aposente, acesso a uma cadeira em um conselho presidencial de notáveis.

Por fim, o "contrato para futuras maiorias" pretende estimular o governante a não agir de forma pragmática visando exclusivamente $\mathrm{o}$ atendimento às maiorias circunstanciais que poderiam granjear ao governante sua recondução ao cargo, mas governar também para as atuais minorias. Por exemplo, caso o governante não seja reeleito, mas vença entre uma determinada faixa etária, e.g. abaixo de 30 anos, teria direito a um benefício, como um bônus econômico ${ }^{438}$, uma vez que seu governo teria se orientado em direção às gerações futuras. Esta hipótese faz sentido quando pensamos em medidas relacionadas ao aquecimento global ou à reforma do sistema previdenciário, que embora possam vir a não interessar a uma maioria de votantes, podem trazer benefício à geração futura, que representaria uma minoria de votantes, a depender do corte etário realizado.

Em relação ao procedimento, Gerbasch propõe que uma "autoridade certificadora" oficial identifique se as propostas observam os valores da democracia liberal, se as propostas são viáveis e se é possível verificar os termos de cumprimento. Esta autoridade, nos parece, poderia assemelhar-se à Agência de Verificação de Propostas Eleitorais, que delineamos no capítulo anterior, cuja criação, especialização e finalidade seriam totalmente compatíveis com esta tarefa.

\footnotetext{
${ }^{437}$ GERSBACH, Hans. Redesigning Democracy. Op. Cit., p. 18.

${ }^{438}$ Nesta hipótese naturalmente o resultado eleitoral teria que demonstrar a votação dos eleitores de forma separada nos blocos etários.
} 
O contrato não seria imutável e poderia ser revisto em casos de circunstâncias extraordinários como guerras e catástrofes, e mediante aprovação de uma super-maioria legislativa $^{439}$.

Gersbach apresenta, contudo, três preocupações em relação ao "contrato limite para reeleição" proposto, reconhecendo a existência de dificuldades para a sua implementação.

Em primeiro lugar o fato de que as políticas públicas são influenciadas por eventos externos e a ocorrência destes eventos poderia conduzir a agenda do governante a cumprir apenas aquelas que autorizariam a reeleição, em detrimento de outras áreas. Tal fato, contudo, não apagaria os efeitos positivos da democracia contratual, segundo Gersbach ${ }^{440}$. Além disso, a situação inclusive poderia ser contornada por meio de procedimento de renegociação, a ser realizado perante o Poder Legislativo.

A segunda inquietação diz respeito ao fato de que apenas parte das políticas públicas pode ser medida, como índices relacionados a macroeconomia, indicadores sociais e ambientais, como desemprego, tributação, mortalidade infantil, etc. Desta forma, será indispensável também apontar os indicadores e órgãos independentes responsáveis por coletar, verificar e apresentar os dados correspondentes. No capítulo anterior exteriorizamos a preocupação com a independência dos órgãos que tratam de tais questões.

Por fim, a gama de áreas que demanda atenção do governo poderia restar limitada pela atuação apenas aos aspectos "contratados", com o escopo de viabilizar a reeleição. Sobre isso Gerbasch responde que o candidato poderia apresentar uma proposta relacionada a apenas uma área, por exemplo, o desemprego. Cumprida referida promessa relacionada ao tema, o governante conquistaria o direito de ser candidato à reeleição, onde poderia submeter à cidadania a análise das outras áreas de seu governo.

Não se olvida também que a oposição poderia se concentrar em impedir o cumprimento das propostas, visando que as consequências atinjam o mandatário. Contudo, é certo que ao realizar uma proposta e ao propor um "contrato politico" o candidato deve ter em conta todas essas perpectivas em consideração que, aliás, constituem vicissitudes inerentes à própria atividade político-democrática.

No sistema proposto não se admitem "contratos políticos privados”, por exemplo, em que o candidato se comprometesse a doar determinada quantia a uma instituição de caridade caso não cumprisse suas promessas. Compromissos desta natureza violariam a

\footnotetext{
${ }^{439}$ GERSBACH, Hans. Contractual Democracy. Op. Cit., p. 832.

${ }^{440}$ GERSBACH, Hans. Contractual Democracy. Op. Cit., p. 841. 198
} 
cláusula democrática, pois permitiria a compra tácita de votos, porquanto haveria um compromisso que posteriormente seria juridicamente exigido. Além disso, colocaria em desvantagem candidatos sem o mesmo poderio econômico.

Ainda, em relação ao fato de a democracia contratual nunca ter sido adotada em nenhum lugar Gersbach oferece duas explicações para essa situação. A primeira é que até o presente momento os "contratos políticos" correspondem a inovações institucionais que não são de simples implementação. A segunda é que após a implementação, a máadministração poderia ser mais transparente à população, de modo que a inovação não a traria grande interesse da classe política ${ }^{441}$.

Por derradeiro, cabe anotar que os "contratos políticos" necessariamente teriam por horizonte as regras democráticas e a observância à lei e à constituição, de modo que qualquer proposta que desborde de tais parâmetros seria afastada pela autoridade certificadora ou pelo Poder Judiciário.

\subsection{Da revisão do "contrato político".}

O "contrato político" seria imutável ou no decurso do mandato poderia o governante, à vista das alterações das condições vigentes, alterar as propostas formuladas? Responder afirmativamente ao questionamento consiste em aplicar, mutatis mutandis a cláusula rebus sic stantibus, vigente nos contratos de direito privado, aos "contratos políticos". Embora a imutabilidade fosse talvez desejável, ela milita contra as idiossincrasias da política.

O sistema jurídico poderia prever, então, para esta hipótese o concurso de outro poder, o Poder Legislativo, que mediante maioria amplamente qualificada dos membros do parlamento, autorizaria a alteração dos compromissos.

Embora se possa reconhecer que tal manobra possa ser objeto de cooptação do Poder Legislativo pela força do Poder Executivo, é certo que o Legislativo é a casa de representação por excelência da cidadania, de modo que é cabível a alteração ${ }^{442}$. A influência do Poder Executivo sobre o Legislativo é mitigada pela exigência de uma super maioria, como, por exemplo, 3/5 dos membros da casa. O quórum elevado visa

${ }^{441}$ GERSBACH, Hans. Contractual Democracy. Op. Cit., p. 845.

${ }^{442}$ Não se pode ignorar que mecanismos deste jaez, visando, por exemplo, impedir penalidades como a vedação à reeleição, motivem condutas políticas ilícitas, como condicionantes para o processo de aprovação da alteração das propostas. 
denotar que a questão é tao relevante que para se alterar a proposta que a cidadania expressamente anuiu seria indispensável grande adesão dos representantes populares.

Uma administração pública focada na qualidade deve ter por norte o estabelecimento de um fluxo de comunicação constante entre os cidadãos e a Administração. Não se trata de um compromisso estático ${ }^{443}$. Poderá se argumentar que um quórum tão elevado poderia limitar em demasia os poderes do governo. Ocorre que aqui, como já mencionamos alhures, trata-se de conferior maior efetividade à proposta eleitoral, de tal sorte que o candidato, ciente de que teria muitas dificuldades no parlamento para conseguir autorização para retroceder em relação a alguma proposta registrada em campanha, deveria ter bastante cuidado para calibrar as propostas que sabe, não poderiam ser cumpridas, ou que demandariam grande capital político para alteração junto ao parlamento.

\subsection{Tutela jurisdicional coletiva das propostas eleitorais.}

A tutela jurisdicional coletiva é o instrumento de proteção dos direitos e interesses coletivos em sentido lato, que abrangem os direitos ou interesses difusos, direitos ou interesses coletivos em sentido estrito (direitos coletivos propriamente ditos) e os direitos individuais homogêneos. Sob lentes processuais é o reconhecimento de que juridicamente o acesso individual não encontraria a proteção adequada, devendo ser aberta a via coletiva, de modo que a solução tomada no processo coletivo evite uma miríadade de decisões contraditórias, além de permitir que seja atingida uma solução mais eficiente aos lesados $^{444}$

A característica comum destes direitos e interesses é que eles são transindividuais, supraindividuais ou metaindividuais, ou seja, pertencem a grupos, classes ou categorias e não somente a indivíduos. Os processos coletivos têm finalidade que supera os interesses

\footnotetext{
443 “Pero ese pacto y compromiso no puede ser estático y atemporal, antes bien habrá de estar sujeito a un proceso de renegociación permanente para adecuarlo a las contingencias de cada momento y lograr así su finalidad esencial, que no es otra que desarrollar la capacidad de integración de los individuos en la sociedad a fin de incrementar el nivel de vida de la comunidad en su conjunto". FERNANDÉZ, Andrés Rodríguez. "La Calidad En La Admnistración Pública". In: Evaluación y Calidad en las Organizaciones Públicas. Colección: Informes y Documentos. Madrid: Instituto Nacional de Administración Pública, 2000, p. 110.

${ }^{444}$ MAZZILLI, Hugo Nigro. A defesa dos interesses difusos em juízo: meio ambiente, consumidor, patrimônio cultural, patrimônio público e outros interesses. São Paulo: Saraiva, 25 ed. rev. ampl. e atual., 2012, p. 51.
} 
meramente individuais, atingindo a realização dos objetivos constitucionais da sociedade e da comunidade ${ }^{445}$.

Daí porque inclusive a representação processual é extraordinária, em que os legitimados tutelam direito subjetivo material de terceiro e os efeitos da coisa julgada atingem pessoas para além das partes que integram a relação processual. Para a nossa pesquisa, interessam os direitos coletivos em sentido estrito, que tem por pressupostos a indivisibilidade de seu objeto, a existência de uma relação jurídica preexistente que une cada um dos indivíduos entre eles próprios ou à parte contrária e a determinabilidade dos titulares do direito. Deste modo, os direitos coletivos em sentido estrito podem ser conceituados como "os interesses ou direitos objetivamente indivisíveis, de que seja titular grupo, classe ou categoria de pessoas, ligadas entre si ou com a parte contrária por um vínculo jurídico base e, por tal razão, determináveis" ${ }^{\text {446 }}$. Mazzilli lembra que enquanto os interesses difusos tem titulares indetermináveis, ligados por situações de fato, os direitos coletivos em sentido estrito referem-se ao "grupo, categoria ou classe de pessoas determinadas ou determináveis, ligadas pela mesma relação jurídica básica"447 ${ }^{\text {. }}$

Retornando às proposições eleitorais e ao vínculo jurídico posteriormente estabelecido pela representação política, nos parece ser possível qualificar, de lege ferenda, como direito coletivo em sentido estrito, a tutela das proposições eleitorais. $\mathrm{O}$ direito à democracia e, por conseguinte, ao cumprimento das propostas eleitorais é naturalmente indivisível. Os titulares de tal direito são primariamente os eleitores, que constituem um grupo determinável de cidadãos que foram previamente submetidos às propostas para que pudessem escolher o candidato que se sagrou vencedor. $\mathrm{O}$ vínculo base estabelecido entre os candidatos e a cidadania é a representação política. Logo, em tese, mediante previsão legal, se poderia construir a teoria para uma tutela jurisdicional coletiva das propostas eleitorais formuladas em campanha.

$\mathrm{Na}$ formulação de Gersbach o descumprimento dos "contratos políticos" impõe consequências jurídicas previamente indicadas pelo próprio candidato. Contudo, tais consequências não se voltam ao objeto último da proposta, que é sua tutela específica, sua implementação. Busca-se que o governante se empenhe no cumprimento das propostas

${ }^{445}$ DIDIER Jr, Fredie, ZANETI Jr. Hermes. Curso de Direito Processual Civil: processo coletivo.

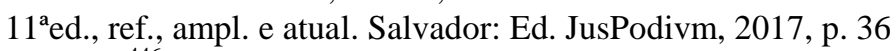

${ }^{446}$ ANDRADE, Adriano; MASSON, Cleber; ANDRADE, Landolfo. Interesses Difusos e Coletivos. São Paulo: Método, $7^{\circ}$ ed. rev. atual. e ampl., 2017, p. 27.

${ }^{447}$ MAZZILLI, Hugo Nigro. A defesa dos interesses difusos em juízo: meio ambiente, consumidor, patrimônio cultural, patrimônio público e outros interesses. São Paulo: Saraiva: 25 ed. rev. ampl. e atual., 2012, p. 56. 
visando obter as consequências positivas do contrato bem como evitar as consequências negativas. Contudo, não há um instrumento de coerção direta e específica ao cumprimento das propostas em si.

Nesta linha, acreditamos ser possível avançar quanto à possibilidade de ser a proposta executada diretamente, por meio de decisão judicial, em hipóteses restritas, a depender da natureza da proposta, e quando se trate de conduta positiva ou negativa que recaia exclusivamente sobre a esfera de competência do Chefe do Poder Executivo.

Nestas hipóteses, o próprio candidato indicaria que uma proposta é "elegível a direito", ou seja, o "contrato político" aqui geraria reflexos para o Poder Judiciário, na medida em que o candidato-proponente estaria voluntariamente submetendo aquela proposta à execução direta caso ele não a cumpra. $O$ candidato demonstra tamanha confiança de que cumprirá a proposta admitindo que, caso não venha a cumpri-la, abre-se a via para que o Poder Judiciário, especificamente pela Justiça Eleitoral, no bojo de ação coletiva, a implemente diretamente. Tal medida teria dois efeitos principais: dar eficácia à proposta que era uma das proposições centrais do candidato, tanto que ele próprio a “elegeu a direito" e, além disso, demonstrar à cidadania que a medida está sendo implementada porque o promitente não cumpriu a obrigação que havia assumido.

Note-se que se trata de uma submissão voluntária do candidato propopente, que ao formular as propostas, indica que determinadas proposições são "elegíveis a direito", estando ciente de que eventualmente poderá ocorrer a tutela específica, em que o Estadojuiz, substituindo-se à função do governante em mora, emite decisão produzindo os efeitos que aguardavam a medida. O mecanismo que apresentamos, de lege ferenda, tem por finalidade, dar concretude, seriedade e exequibilidade, a propostas minudentes, representando um instrumento adicional aos contratos politicos.

A adesão por parte da cidadania ao "contrato político" ocorre no instante em que o candidato é eleito, de modo que a eleição passa a gerar como efeito primário sua assunção ao cargo, com a diplomação e posse, mas também gera o efeito obrigacional de se orientar em direção ao cumprimento das propostas. No sistema de Gersbach a adesão às propostas ocorre de forma una, ou seja, ou o candidato é eleito e em relação a todos os comprimissos passa a pesar o ônus obrigacional do cumprimento, ou o candidato não é eleito e naturalmente está exonerado de qualquer obrigação. Entretanto, seria possível também que a cidadania aderisse parcialmente ao contrato, ou seja, no próprio momento da votação, os eleitores escolhessem não apenas os candidatos, mas também assinalassem a quais de suas propostas aderiam com o escopo de acolher as "cláusulas elegíveis a 
direito". Trata-se de verdadeiro exercício de modalidade de democracia direta para a formação do plano de governo, mas agora com caráter coercitivo. Portanto, eleito o candidato, identificam-se quais propostas com "cláusula elegível a direito" foram igualmente "eleitas" para que tenham força cogente no curso do mandato.

Trata-se de uma tutela coletiva das propostas eleitorais que tenham sido submetidas ao regime de contratos políticos. A tutela é coletiva porque não seria viável que um cidadão, individualmente, pretendesse a implementação da proposta uma vez que o oblato é a cidadania, a coletividade, e o bem jurídico protegido é a higidez e a efetividade democrática. Portanto, se contrapõe à ação popular, que admite no polo ativo que individualmente cidadãos ingressem com demanda judicial, mas o bem tutelado é restrito a atos lesivos ao patrimônio público ${ }^{448}$.

Após a implementação do sistema, caberia aos órgãos eleitorais realizar campanha educativa para orientar os eleitores sobre a nova forma de funcionamento eleitoral, demonstrando aos eleitores que o programa eleitoral teria de ser buscado no governo, havendo instrumentos jurídicos para a sua implementação, quando não dependesse do concurso de outros poderes. Esse sistema privilegiaria, em tese, uma maior responsabilização de ambos os polos envolvidos no sistema eleitoral, pois a figura do eleitor estaria migrando de um sistema em que ele se limita à escolha dos representantes para um sistema em que, além da escolha do governante, o eleitor irá aderir a propostas do programa que podem vir a ser diretamente implementadas.

Mencionamos no capítulo anterior um exemplo que poderia ilustrar essa questão. $\mathrm{O}$ então candidato Jair Bolsonaro, na eleição presidencial de 2018, expressamente, e em várias oportunidades durante a campanha, se comprometeu a promover ações para tornar mais fácil o acesso ao porte de $\operatorname{armas}^{449}$, sendo que uma pesquisa revelou que $61 \%$ da população era contrária à flexibilização da posse de $\operatorname{armas}^{450}$. Com a adoção do "contrato político", com esta questão sendo colocada pelo candidato como "proposta elegível a direito", o eleitor teria que optar entre escolher o candidato, ciente de que tal medida seria implementada, inclusive por meio de tutela judicial coletiva, ou priorizar sua opinião pessoal em relação ao desarmamento, deixando de escolher o candidato.

${ }^{448}$ Art. $1^{\circ}$ da Lei Federal n ${ }^{\circ} 4.717 / 65$

449 Disponível em: <https://congressoemfoco.uol.com.br/eleicoes/maioria-dos-presidenciaveisdefende-desarmamento-veja-a-posicao-de-cada-um/> . Acesso em 13/03/219.

${ }^{450}$ Disponível em: <https://g1.globo.com/politica/noticia/2018/12/31/para-61-dos-brasileiros-possede-armas-de-fogo-deve-ser-proibida-diz-datafolha.ghtml> . Acesso em 13/0/2019. 
No início deste Capítulo sugerimos que o descumprimento do compromisso de cumprimento integral do mandato se tornasse hipótese legal de inelegibilidade. Porém, à míngua de tal regramento, o compromisso poderia também ser realizado pelo próprio candidato e, tratando-se de proposta "elegível a direito", ou seja, ele próprio assumindo a consequência de não poder participar do pleito antes do término do cumprimento do mandato para o qual foi eleito originariamente, o descumprimento da promessa implicaria no indeferimento da nova candidatura.

Não se pretende impedir a realização de propostas genéricas, tais como promover maior distribuição de riqueza, melhorar e ampliar os serviços públicos gratuitos, etc. É preciso reconhecer que elas fazem parte do jogo político. Naturalmente seria inviável e inexequível exigir que todas as propostas fossem adrede pormenorizadas. A própria consecução de muitos objetivos realmente depende de outros fatores e inclusive do concurso de outros poderes, órgãos e instituições. Por essas razões, seria absolutamente inviável pretender conferir de forma indistinta a tutela cogente de todas as proposições realizadas pelos candidatos por meio do Poder Judiciário, o que justifica a limitação às propostas escolhidas pelo próprio candidato.

De fato, o espectro relacionado às propostas materialmente objetivas é reduzido. Por exemplo, a promessa de queda da taxa de juros, construção de hospitais, escolas, contratações, realizadas de forma genérica, naturalmente não podem ser submetidas a pedido direto ao Poder Judiciário, na medida em que dependem de reserva orçamentária e concurso do Poder Legislativo.

Estamos certos que aqui diversas críticas se apresentam, notadamente sob o ingresso do Poder Judiciário em esfera eminentemente política, em especial em um período histórico em que várias críticas se apresentam às leituras neoconstitucionalistas que tem dado maior musculatura ao Poder Judiciário. Na mesma linha, cabe questionar se essa inserção implicaria no cumprimento de atividade primária do Poder Judiciário, resolvendo o conflito em hipótese de interesses transindividuais ou serviria de agente catalisador a gerar maior conflito entres os poderes da República.

Por fim, embora o natural foco de análise esteja no dever que recairia sobre o proponente, nos parece que, em tese, o contratualismo traria maior responsabilidade também sobre os cidadãos eleitores. Atualmente, os eleitores de um governanente que tenha apresentado um desempenho ruim podem compreender que não tem qualquer responsabilidade pelas metas e planos escolhidos, já que se limitam à "escolha" do governante. Entretanto, em tese, adotado o sistema de "contratos políticos", a 
implementação das medidas contaria com a expressa anuência dos eleitores, que conduziram o candidato ao poder, cientes das medidas essenciais por eles próprios escolhidas a nortear sua administração e sujeitas à implementação por meio do Poder Judiciário. Atualmente o maior interesse político guarda vínculo com momentos de crise econômica. A contratualização poderia auxiliar no incremento do interesse político, que por sua vez favorece uma maior participação eleitoral ${ }^{451}$.

Ressalte-se que não seria possível a habilitação de interessados particulares, valendo-se do título executivo judicial coletivo, com o escopo de identificar a reparação a eventual prejuízo individual. Até onde avançamos no objeto de nossa pesquisa não vislumbramos a possibilidade de indenização por perdas e danos em decorrência do descumprimento das propostas, seja de caráter ressarcitório individual ou coletivo. Nosso argumento volta-se à implementação coercitiva da proposição, acaso inserida dentro das proposições materialmente objetivas, e por meio de tutela coletiva. Tal passo já nos parece bastante ousado e de complexa implementação, mas tem por foco a preservação e o aprimoramento do regime democrático. Avançar para a responsabilidade civil do Chefe do Poder Executivo pelo descumprimento da proposta se apresentaria ainda mais complexo, além de desbordar do próprio interesse coletivo que delimitamos relacionado ao aprimoramento do regime democrático.

Não se descarta, porém, a eventual aplicação cumulativa de multa ao agente descumpridor da proposta, em cumulação com a aplicação da tutela coletiva específica, exatamente porque a repercussão econômica é um relevante instrumento que poderia inibir os governantes de formularem propostas demagógicas, cientes de que poderiam sofrer sancionamento pecuniário. Os valores recolhidos deveriam ser destinados a um fundo específico, com a mesma moldura da tutela coletiva nas ações civis públicas.

Analisaremos algumas situações práticas envolvendo propostas eleitorais e um julgado em que tive a oportunidade de identificar a aplicação da teoria da imprevisão na esfera administrativa.

No exemplo que mencionamos do compromisso realizado pelo candidato Fernando Haddad em relação a não concessão de indulto ao ex-presidente Lula algumas questões merecem análise. Em primeiro lugar, cabe lembrar que o indulto é uma prerrogativa

451 Pesquisa realizada na União Europeia em 1999 demonstra uma relação proporcional entre interesse na política e comparecimento às eleições. Por exemplo, na Espanha, entre aqueles que apresentavam baixo interesse pela política, apenas $76 \%$ compareciam aos pleitos eleitorais, enquanto entre os que apresentavam alto interesse o índice atinge 92\% de comparecimento eleitoral. ANDUIZA, Eva e BOSCH, Agustí. Comportamiento político y electoral. Barcelona: Ariel, 2000, p.128. 
constitucional exclusiva do Presidente da República ${ }^{452}$. Portanto, acaso referida proposta constasse do "contrato político" por nós proposto, e uma vez eleito o candidato viesse a conceder o indulto, a medida seria passível de anulação judicial, caso elevada alçada como “elegível a direito". Isso porque ao realizar o compromisso expresso de não indultar o expresidente, o candidato renunciou, de forma consciente, a parcela de sua prerrogativa constitucional.

Também no pleito do ano de 2018, o então candidato a governador pelo Estado de Minas Gerais pelo Partido Novo, Romeu Zema, por meio de compromisso registrado em um cartório extrajudicial, afirmou que ele, o candidato a vice-governador e todos os seus secretários não receberiam salários enquanto houvesse um único funcionário do estado, ativo ou inativo, com vencimentos, aposentadorias ou pensões em atraso ou objeto de parcelamento. Entretanto, após lograr sucesso no pleito, o governador recuou, afirmando que por lei era obrigado a receber o salário, além de reconhecer que teria se tratado de um “erro de campanha" e que, na verdade, era necessário reajustar o salário dos secretários ${ }^{453}$. Estivesse referido compromisso no bojo de um "contrato político", a possibilidade jurídica do pedido já teria sido apreciada antes da eleição e, caso se tratasse de cláusula "elegível a direito", restaria evidenciado o descumprimento do compromisso, podendo haver a previsão de sanção para tal hipótese.

Tivemos a oportunidade de nos deparar com um caso típico de exclusão da coercibilidade fundado na teoria da imprevisão. Em concursos públicos é cediço que o candidato aprovado dentro do número de vagas tem direito à nomeação, dentro do prazo de validade do concurso. Tal entendimento já foi sedimentado pelo Superior Tribunal de Justiça e pelo C. Supremo Tribunal Federal, este, em julgamento pelo sistema de repercussão geral (Tema n. ${ }^{\circ}$ 161). Entretanto, o plenário do Supremo Tribunal Federal, reconheceu que o direito subjetivo à nomeação do candidato aprovado dentro do número de vagas pode ser afastado desde que verificadas determinadas condições, quais sejam, a identificação da superveniência (após a publicação do edital) de situação excepcional,

${ }^{452}$ Constituição Federal, artigo 84, XII. Entretanto, malgrado o texto constitucional não imponha limites à concessão do indulto, o Supremo Tribunal Federal apreciou a Ação Direta de Inconstitucionalidade $\mathrm{n}^{\circ}$ 5874, rel. Min. Luiz Roberto Barroso, no qual foi concedido efeito suspensivo e se questionava o Decreto Presidencial $n^{\circ} 9.246 / 2017$ que concedeu o indulto de Natal, especificamente a necessidade de observância pelo Presidente de critérios para a concessão da benesse. Ao final, a ação foi julgada improcedente, vencido o relator.

453 Disponível em: <https://politica.estadao.com.br/noticias/geral,zema-diz-que-errou-ao-prometerque-nao-pagaria-salario-a-secretarios-estaduais,70002871197>. Acesso em 13/09/2019. 
imprevisível e grave, não existindo outras medidas menos gravosas para combater a situação apontada como justificativa para a não nomeação ${ }^{454}$.

No processo que estava sob nossa relatoria junto à Turma Recursal da Fazenda Pública de Santo André, foi negado provimento ao recurso em face da sentença que havia julgado improcedente o pedido de nomeação do candidato aprovado dentro do número de vagas. O fundamento foi o Decreto Estadual (SP) $\mathrm{n}^{\circ} 1.466 / 2015$, que vedou a admissão e contratação de pessoal no âmbito da administração indireta, bem como o aproveitamento

454 RECURSO EXTRAORDINÁRIO. REPERCUSSÃO GERAL. CONCURSO PÚBLICO. PREVISÃO DE VAGAS EM EDITAL. DIREITO À NOMEAÇÃO DOS CANDIDATOS APROVADOS. I. DIREITO À NOMEAÇÃO. CANDIDATO APROVADO DENTRO DO NÚMERO DE VAGAS PREVISTAS NO EDITAL. Dentro do prazo de validade do concurso, a Administração poderá escolher o momento no qual se realizará a nomeação, mas não poderá dispor sobre a própria nomeação, a qual, de acordo com o edital, passa a constituir um direito do concursando aprovado e, dessa forma, um dever imposto ao poder público. Uma vez publicado o edital do concurso com número específico de vagas, o ato da Administração que declara os candidatos aprovados no certame cria um dever de nomeação para a própria Administração e, portanto, um direito à nomeação titularizado pelo candidato aprovado dentro desse número de vagas. (...) III. SITUAÇÕES EXCEPCIONAIS. NECESSIDADE DE MOTIVAÇÃO. CONTROLE PELO PODER JUDICIÁRIO. Quando se afirma que a Administração Pública tem a obrigação de nomear os aprovados dentro do número de vagas previsto no edital, deve-se levar em consideração a possibilidade de situações excepcionalíssimas que justifiquem soluções diferenciadas, devidamente motivadas de acordo com o interesse público. Não se pode ignorar que determinadas situações excepcionais podem exigir a recusa da Administração Pública de nomear novos servidores. Para justificar o excepcionalíssimo não cumprimento do dever de nomeação por parte da Administração Pública, é necessário que a situação justificadora seja dotada das seguintes características: a) Superveniência: os eventuais fatos ensejadores de uma situação excepcional devem ser necessariamente posteriores à publicação do edital do certame público; b) Imprevisibilidade: a situação deve ser determinada por circunstâncias extraordinárias, imprevisíveis à época da publicação do edital; c) Gravidade: os acontecimentos extraordinários e imprevisíveis devem ser extremamente graves, implicando onerosidade excessiva, dificuldade ou mesmo impossibilidade de cumprimento efetivo das regras do edital; d) Necessidade: a solução drástica e excepcional de não cumprimento do dever de nomeação deve ser extremamente necessária, de forma que a Administração somente pode adotar tal medida quando absolutamente não existirem outros meios menos gravosos para lidar com a situação excepcional e imprevisível. De toda forma, a recusa de nomear candidato aprovado dentro do número de vagas deve ser devidamente motivada e, dessa forma, passível de controle pelo Poder Judiciário. IV. FORÇA NORMATIVA DO PRINCÍPIO DO CONCURSO PÚBLICO. Esse entendimento, na medida em que atesta a existência de um direito subjetivo à nomeação, reconhece e preserva da melhor forma a força normativa do princípio do concurso público, que vincula diretamente a Administração. É preciso reconhecer que a efetividade da exigência constitucional do concurso público, como uma incomensurável conquista da cidadania no Brasil, permanece condicionada à observância, pelo Poder Público, de normas de organização e procedimento e, principalmente, de garantias fundamentais que possibilitem o seu pleno exercício pelos cidadãos. $\mathrm{O}$ reconhecimento de um direito subjetivo à nomeação deve passar a impor limites à atuação da Administração Pública e dela exigir o estrito cumprimento das normas que regem os certames, com especial observância dos deveres de boa-fé e incondicional respeito à confiança dos cidadãos. $\mathrm{O}$ princípio constitucional do concurso público é fortalecido quando o Poder Público assegura e observa as garantias fundamentais que viabilizam a efetividade desse princípio. Ao lado das garantias de publicidade, isonomia, transparência, impessoalidade, entre outras, o direito à nomeação representa também uma garantia fundamental da plena efetividade do princípio do concurso público. V. NEGADO PROVIMENTO AO RECURSO EXTRAORDINÁRIO (Tribunal Pleno, RE 598099/MS, Rel. Min. GILMAR MENDES, julgado em 10/08/2011) (grifo nosso.). 
de remanescentes de concursos públicos com prazo de validade em vigor, ou seja, medida adotada de forma indistinta em todo o Estado, à vista da crise econômica ${ }^{455}$.

Portanto, reconheceu-se que a crise econômica, tal como posta, autorizava a não nomeação. Mutatis mutandis, trazendo referido entendimento ao tema proposto, o candidato que tivesse realizado compromisso eleitoral de mesma natureza relacionada à contratação de pessoal, poderia ser exonerado do cumprimento. Ressalto, contudo, que tal análise caberia à AVPE, e não ao Poder Judiciário. Tal entendimento corresponderia à aplicação da teoria da imprevisão às "cláusulas elegíveis a direito" dos "contratos políticos", exonerando o proponente do dever de cumprimento e impedindo a tutela específica.

Na campanha presidencial espanhola de 2015, que mencionamos no Capítulo 3, item 6, o Partido Podemos formulou proposta específica na área de educação, limitando o número máximo de alunos por sala de aula para cada grau de ensino. Trata-se de compromisso legal, materialmente objetivo, de modo que constante de "cláusula elegível a direito" no bojo de "contrato político", pode dar ensejo à tutela específica, cabendo, naturalmente, a análise de eventuais escusas por parte do governante.

Ainda em território espanhol, o Partido Vox, nas eleições nacionais de 2019 formulou proposta de medidas relacionadas à democracia interna dos partidos políticos, em que os cargos representativos seriam escolhidos por meio de sufrágio direto e secreto, além de auditorias externas independentes, entre outras medidas ${ }^{456}$. Cabe ressaltar que, tratandose de uma monarquia parlamentarista, e se estivessemos diante de uma proposta de "contrato político" com "cláusula elegível a direito", os efeitos deveriam recair sobre o partido político, e não sobre a pessoa física que, após a eleição seja indicada para o cargo de "Presidente do Governo". No caso, presumindo que se trata de hipótese que demanda aprovação de lei pelo parlamento, caberia ao partido o encaminhamento do projeto, cuja omissão poderia implicar em tutela específica consistente em determinar que o partido o encaminhe ao parlamento, sob pena de, no silêncio, o autor ação, legitimado para exigir o cumprimento, encaminhe ele próprio o projeto de lei. Pode-se questionar o fato de que o

${ }^{455}$ Concurso Público - ação de obrigação de fazer - candidata aprovada dentro do número de vagas previsto no edital que a princípio tem direito subjetivo à nomeação - RE no 598.099/MS que desobriga a contratação diante da efetiva comprovação da existência de situações excepcionalíssimas - crise econômica verificada - Decreto Estadual n ${ }^{\circ} 1.466 / 2015$ no qual o Chefe do Executivo veda a realização de todo tipo de contratação - sentença de improcedência mantida (TJSP; Recurso Inominado 1015799-63.2017.8.26.0554; Relator (a): Glauco Costa Leite; Órgão Julgador: Turma Recursal - Fazenda Pública; Foro de Santo Andr; Data do Julgamento: 06/02/2018; Data de Registro: 06/02/2018).

456 Disponível no item 1.6 do Programa Eleitoral em: <https://www.voxespana.es/wpcontent/uploads/2015/12/Programa-electoral-VOX-26-J.pdf>. Acesso em 29/10/2019. 
legitimado talvez já possuísse a prerrogativa de encaminhar projeto de lei para discussão. Ocorre que na hipótese vislumbrada, o Poder Judiciário teria atestado a mora do partido em cumprir seu compromisso e também poderia haver a previsão, como mencionamos, da aplicação de multa. Por fim, não é demais lembrar que a apreciação do projeto constitui prerrogativa soberana do Parlamento.

\subsection{Do Procedimento de tutela judicial das propostas eleitorais.}

Com o escopo de oferecer certa materialização a nossa proposta, da mesma forma que realizamos no Capítulo 4 em relação à AVPE e o controle administrativo das propostas, trazemos algumas linhas gerais do que poderia representar um procedimento para implementação dos "contratos políticos", com ou sem cláusulas, "elegíveis a direito".

\subsubsection{Do registro do "contrato político" e da avaliação preliminar.}

O procedimento inicia-se com o registro do "contrato político", que deve se dar naturalmente perante o órgão responsável pelas eleições, que no Brasil é a Justiça Eleitoral, responsável pelo controle extrínseco da proposta. Entretanto, como sugerimos que a avalição do cumprimento das propostas e da própria viabilidade da aferição seja realizada por órgão administrativo autônomo, o "contrato político" também deve ser apresentado à autoridade certificadora que, segundo nossa sugestão, corresponderia à AVPE.

Diferentemente da análise que delianeamos na AVPE, em que em uma primeira fase não há qualquer apreciação sobre o mérito das propostas - inclusive sua exequibilidade - mas tão somente a formação do quadro geral de propostas, aqui o filtro à proposta é anterior ao pleito. Entre as próprias promessas registradas como "elegíveis a direito", como chamamos os compromissos que dariam ensejo ao implemento de forma cogente, constantes do "contrato político", não se admitiriam propostas ilícitas ou fora do espectro de competência do proponente, como no caso do candidato a governador que promete implementar a legalização do aborto no estado em que concorre. Na mesma linha, evidente que não se pode impedir o candidato de dizer que baixará os juros, mesmo a despeito das condições desfavoráveis, mas ao menos a população poderia compreender que tal proposta não é implementável de forma cogente, nao aprovada como "elegível a direito" pela AVPE, de modo que a cidadania saberia preliminarmente ao pleito, portanto, que não haveria como garantir seu cumprimento. Por exemplo, no programa eleitoral do 
Partido Socialista Espanhol para as eleições nacionais de 2019, o partido se compromete a reduzir 20\% das emissões de gases de efeito estufa. Embora tal medida possa ser "aferida" pela AVPE, para efeitos de controle administrativo, em relação ao cumprimento, não há como determinar a imposição da tutela específica, dada à multiplicidade de fatores e medidas que são indispensáveis para a efetividade da redução ${ }^{457}$.

A autarquia, de seu turno, e ainda dentro do período eleitoral, indicaria se as propostas que estão incluídas no contrato podem ser identificadas como "objetivas legais exequíveis", que implica em filtrar os compromissos quanto à possibilidade de aferição ${ }^{458}$. A autoridade certificadora limita-se a responder ao seguinte questionamento: "referida proposta é legal e pode ser aferida de forma objetiva?". Portanto, apenas em face de uma proposta totalmente objetiva, ou seja, não se tratando de conceito jurídico indeterminado, não estando sujeito a reserva legal e não havendo necessidade de reserva financeira ou concurso de outros poderes, seria viável que a proposta fosse exigível diretamente pelo Poder Judiciário.

Positiva a resposta, a proposta é certificada como "materialmente objetiva". O órgão igualmente dá um parecer quanto à conformação das propostas e das consequências previstas no "contrato político" ao ordenamento jurídico. Em relação às cláusulas “elegíveis a direito", a autoridade certificadora apenas se manifesta quanto à aferição e a legalidade, não fazendo qualquer juízo quando à possibilidade de implementação direta da tutela, questão que cabe exclusivamente ao Poder Judiciário.

Portanto, à AVPE cabe a análise da legalidade da proposta e da possibilidade de aferição, ao passo que o Poder Judiciário fica reservada a tutela jurisdicional para que a proposta seja diretamente implementada.

Como delineado ao tratar da natureza das decisões da AVPE, da decisão que reconhece ou nega a possibilidade, em tese, de que a questão seja submetida ao Poder Judiciário em razão da natureza da proposta, caberia recurso administrativo. Não havendo recurso, a questão não poderia ser levada posteriormente ao Poder Judiciário. Explico. A lei poderia prever prazo decadencial para o questionamento judicial da decisão administrativa que negou a possibilidade de tutela judicial futura face a determinadas propostas e, escoado o prazo, não poderia a parte interessada ingressar com posterior ação

457 Disponível em: <https://www.psoe.es/media-content/2019/04/PSOE-programa-electoralelecciones-generales-28-de-abril-de-2019.pdf>. Acesso em 29/10/2019, p. 43.

${ }^{458}$ No Capítulo 3, item 3.6, consta a classificação que realizamos em relação às modalidades de proposições eleitorais. 
de obrigação de fazer tendo por objeto o pedido de cumprimento da proposta, já que não recorreu da decisão da AVPE que não reconheceu o objeto da cláusula "elegível a direito", como legal e materialmente objetiva.

Em tese, da decisão administrativa proferida, prévia ao pleito eleitoral, o corpo eleitoral teria condições de avaliar de forma qualitativa e quantitativa se o contrato realmente poderia ser implementado. Bem por isso, os prazos para habilitação de candidatos e apresentação de propostas deveriam ser suficientemente anteriores ao pleito eleitoral para que à época do certamente, tais questões já estejam solucionadas. Isso não impediria a formulação de outras propostas e compromissos durante a campanha eleitoral, mas que estariam sujeitas apenas ao escrutínio administrativo.

\subsubsection{Da competência.}

Como mencionado, a competência para apreciação dos pedidos de tutela coletiva das proposições eleitorais de campanha seria da Justiça Eleitoral, na medida em que se está a qualificar a escolha democrática realizada pela cidadania. Afinal, é a Justiça Eleitoral responsável por todo o procedimento eleitoral, desde a habilitação do eleitor e dos candidatos até a diplomação, passando pela campanha eleitoral, eleições e apuração.

$\mathrm{Na}$ nossa proposta, o espectro da Justiça Eleitoral passa também a abranger a apreciação dos processos de tutela específica das propostas eleitorais. Deste modo, hierarquicamente, e dado o paralelismo constitucional, competiria ao Tribunal Superior Eleitoral a apreciação dos pedidos em relação ao Presidente de República, ao Tribunal Regional Eleitoral os processos em face de governadores de Estado e do Distrito Federal e as zonas eleitorais em relação às demandas que tramitem contra os chefes do Poder Executivo municipal.

\subsubsection{Da legitimidade.}

Quanto à legitimição ativa para a ação judicial não haveria razão para autorizar o indivíduo a propor a demanda, uma vez que como oblato do contrato figura toda a coletividade, e não apenas um eleitor, como já mencionados. Assim, a legitimidade poderia seguir alguns dos parâmetros de leis que regem as ações coletivas, como, por 
exemplo, a Lei de Ação Civil Pública (Lei Federal n $\left.{ }^{\circ} 7.347 / 1985\right)^{459}$. Em relação ao Ministério Público e à Defensoria Pública deve ser reconhecida a legitimação universal para a tutela de qualquer tipo de proposta, na medida em que estes entes têm entre suas atribuições a defesa do regime democrático, a defesa de interesses públicos e interesses coletivos em sentido lado.

Em relação à União, Estados, Distrito Federal e Municípios, a dificuldade seria que as respectivas procuradorias têm por prerrogativa a defesa institucional dos atos do Chefe do Poder Executivo, de modo que não faria sentido que fossem legitimadas a questionar o descumprimento das proposições contra quem as instituições detêm atribuições para defender. Em relação às autarquias, empresas públicas, fundações, sociedades de economia mista ou associação civil constituída há mais de ano, necessário que se identifique pertinência temática entre as suas atribuições institucionais e o objeto da proposta descumprida, ou seja, a finalidade institucional da entidade se compatibilize com a defesa judicial do interesse ${ }^{460}$. Por exemplo, a CETESB - Companhia Ambiental do Estado de São Paulo, sociedade de economia mista, teria legitimidade para ingressar em face do Chefe do Executivo que não estivesse levando a cumprimento o compromisso na área ambiental realizado com a cláusula "elegível a direito"461.

Os partidos políticos, essenciais ao funcionamento democrático, naturalmente devem ser legitimados a provocar o Poder Judiciário visando a implementação das medidas que o governante proponente não estaria cumprindo. Ademais, é certo que o partido derrotado teria interesse em demonstrar que o candidato do partido vencedor descumpriu os compromissos que deram origem à vitória obtida. Os partidos políticos têm legimitidade para propor ações diretas de inconstitucionalidade, ação civil pública e mandado de segurança coletivo. Considerando-se que os partidos políticos também têm por pressuposto a defesa da ordem democrática, não seria necessária a verificação de pertinência temática entre suas atribuições e o objeto da proposta descumprida.

\footnotetext{
${ }^{459}$ Referido diploma apresenta em seu artigo $5^{\circ}$ como legitimados: Ministério Público, Defensoria Pública, Uniao, Estados, Distrito Federal e Municípios, autarquia, empresa pública, fundação ou sociedade de economia mista e, com pertinência temática, associação civil constituída há mais de ano.

${ }^{460}$ MAZZILLI, Hugo Nigro. A defesa dos interesses difusos em juízo: meio ambiente, consumidor, patrimônio cultural, patrimônio público e outros interesses. Op. Cit., p. 326.

${ }^{461}$ Não se ignora que, na prática, órgãos que tem vinculação institucional vertical com o Poder Executivo certamente ficariam inibidos em tormar medida desta natureza. A CETESB, por exemplo, é um "órgão delegado do Governo do Estado de São Paulo", cabendo ao Poder Executivo a designação da subvenção ao órgão por meio da proposta orçamentária anual. Além disso. O Governo do Estado detem a maioria das ações, o que repercute nas indicações ao conselho e presidência (Lei Estadual n 118/1973).
} 
O Ministério Público, quando não for autor da demanda, necessariamente atuará como fiscal da lei.

Se o compromisso é realizado pelo candidato e seu respectivo candidato a vice, é certo que cada qual ou ambos devem figurar no polo passivo da demanda. Não faria sentido em se colocar a pessoa jurídica de direito público no pólo de defesa, uma vez que, na verdade, a mora contratual é do candidato proponente que, por sua vez, vale-se da Administração como instrumento de implementação das propostas. Portanto, apenas a pessoa física do proponente, na figura do chefe e vice-chefe do Poder Executivo, podem integrar o polo passivo e não a pessoa jurídica de direito público que presidem.

Como aludido, a cidadania não poderia ser cindida pelos interesses objeto das propostas, de modo que a denominada fase de cumprimento de sentença teria a mesma legitimação ativa coletiva. $\mathrm{O}$ apontamento nos parece relevante na medida em que particulares poderiam sustentar a existência de prejuízos em razão do não cumprimento da proposta, ainda que por via reflexa. Por exemplo, em relação à proposta de aumento da velocidade máxima das marginais no município de São Paulo, motoristas de táxi ou de aplicativos de transporte poderiam sustentar que o descumprimento da proposta os impediu de realizar um maior número de contratos de transporte, reduzindo sua renda, razão pela qual teriam sofrido prejuízos com o descumprimento.

\subsubsection{Do processo judicial nos contratos com "cláusulas elegíveis a direito”.}

Escoado o procedimento administrativo prévio de identificação das propostas materialmente objetivas passa-se à fase de reclamação quanto ao descumprimento das cláusulas contratuais, em que o procedimento tramita perante o Poder Judiciário, auxiliado pela autoridade certificadora. Isso porque, conforme alinhamos no Capítulo anterior esta autoridade, com multiplicidade técnica em seus quadros, seria talhada para aferir o cumprimento das propostas. Portanto, é a ela que caberia a palavra meritória quanto ao cumprimento das propostas e eventuais alegações de impossibilidade de cumprimento.

De outro lado, apenas perante a Justiça Eleitoral poderia ser reclamada a tutela específica, em relação às cláusulas "elegíveis a direito", porque nestas hipóteses o candidato espontaneamente se submeteu a esta possibilidade.

Portanto, não havendo cláusula "elegível a direito", a reclamação será realizada apenas em face da autoridade certificadora, a AVPE, que atestando o descumprimento, 
autoriza o legitimado a buscar as consequências jurídicas previstas no contrato, já declaradas pela própria autoridade administrativa.

Para ilustrar a questão imaginemos duas cláusulas contratuais. Na primeira o proponente afirma que tomará determinada medida sob pena de, não a realizando, não poder concorrer à reeleição. Na segunda, o mesmo compromisso é realizado, mas como "cláusula elegível a direito". $\mathrm{Na}$ primeira hipótese o procedimento tramita exclusivamente pela AVPE, que reconhecendo o descumprimento, impõe a penalidade, prevista contratualmente, de impossibilidade de concorrer ao próximo pleito. Na segunda hipótese, a parte legitimada ingressa com ação judicial para que a medida descumprida seja efetivamente implementada, após manifestação da AVPE sobre o cumprimento, sem prejuízo do reconhecimento da vedação à reeleição.

O direito à tutela não decorre simplesmente da mora do Chefe do Poder Executivo, pois o Poder Judicário poderá desprover o pedido, sob o argumento de que o cumprimento exigia recursos ou anuência de outros órgãos e poderes, ou seja, reconheceria que embora materialmente objetiva e, portanto, aferível, o cumprimento dependeria também do concurso de outros agentes, de modo que a tutela judicial nestes casos atentaria contra o equilíbrio de poderes.

Proposta a demanda o governante seria citado para contestar a acusação de descumprimento, seja afirmando seu cumprimento ou apresentando escusa legal. A demonstração de que a proposta objeto da demanda foi identificada pela AVPE em sede administrativa como legal materialmente objetiva é condição da procedibilidade de ação.

As hipóteses que podem isentar o governante do dever de cumprimento das propostas já foram objeto de estudo nos itens 4.8.1 a 4.8.5 do Capítulo 4. Após a resposta, o Poder Judiciário intima a AVPE para que emita parecer nos autos acerca do cumprimento da proposta. Preliminarmente a AVPE deve confirmar que a proposta em tela foi reconhecida como legal materialmente objetiva. Em seguida demonstra se a proposta foi cumprida e, em caso negativo, se manifesta sobre eventual justificativa apresentada. Portanto, é a autarquia quem tem legitimidade exclusiva para apreciar a responsabilidade e a culpa do governante promitente.

O Poder Judiciário não terá o condão de interferir na apreciação de mérito quanto ao prévio cumprimento da proposta. Logo, tendo a AVPE reconhecido o descumprimento e afastado as justificativas, caberá ao Poder Judiciário, por meio da Justiça Eleitoral, a determinação de meios para a implementação. Ao contrário, tendo a AVPE atestado o cumprimento ou acolhido a justificativa, a ação judicial deve ser julgada improcedente. Por 
tal razão, não se reconhece a possibilidade de concessão de tutela de urgência, já que o parecer da AVPE é pressuposto de mérito para a sentença que determina a obrigação de fazer por meio de tutela específica.

Questão interessante seria identificar a possibilidade de transação nos processos coletivos em análise. O legitimado extraordinário defende direito alheio, logo, a rigor não pode dispor sobre o direito material da lide, que abrange interesse de terceiros. Contudo, em relação às ações civis públicas, aspectos de conveniência prática têm mitigado a vedação, que ocorre por meio de termos de ajustamento de conduta, em que qualquer colegitimado para a propositura de ação civil pública pode celebrá-los. Tais termos, em síntese, correspondem a modalidade de transação ${ }^{462}$. Na hipótese dos contratos políticos com "cláusulas elegíveis a direito", acreditamos ser necessário um maior aprofundamento do tema para verificar as vantagens e desvantagens de adoção do instituto. Isso porque se de um lado ele poderia ser aproveitado, por se tratarem dos mesmos pressupostos, de outro, a celebração de termo de ajustamento de conduta com algum colegitimado, poderia ocorrer à revelia de demais legitimados e, potencialmente, gerar situações de fraude, em que o próprio governante instasse um colegitimado a ingressar com ação, com o escopo de celebrar termo de ajustamento de conduta em situações mais favoráveis a ele, impedindo que outros colegitimados ingressem com a demanda coletiva, que já estaria judicializada.

Por fim, com a prolação da sentença se determinaria o cumprimento da proposta, consistente na tomada de providências para que a implementação ocorra de maneira direta. Assim, o próprio Poder Judicial, em sua esfera eleitoral, determinaria a aplicação do cumprimento da proposta, no bojo da ação coletiva.

$\mathrm{Na}$ tutela coletiva das propostas eleitorais, a decisão que determina a implementação do conteúdo de "cláusula elegível a direito" tem natureza condenatória mandamental, reconhecendo o direito do autor à aplicação de uma sanção executiva ao requerido com a execução específica do cumprimento da obrigação ${ }^{463}$. A sentença tem por

${ }^{462}$ MAZZILLI, Hugo Nigro. A defesa dos interesses difusos em juízo: meio ambiente, consumidor, patrimônio cultural, patrimônio público e outros interesses. Op. Cit., pp. 426-427.

463 "Em virtude de sua acentuada imperatividade, acompanhada de severas sanções pelo inadimplemento, as sentenças que determinam o adimplemento dessas obrigações consideradas específicas (em confronto com as obrigações de conteúdo pecuniário, que são genéricas) enquadram-se no conceito de sentenças mandamentais - as quais são dotadas da mesma estrutura lógico-substancial das condenatórias clássicas, compondo-se, portanto, de um momento declaratório, onde o direito do autor é reconhecido, e de um momento sancionador, que abre caminho para a execução forçada. A sentença mandamental é título para a execução forçada (cumprimento da sentença), tanto quanto a condenatória ordinária - e portanto é também uma condenação. A diferença está no conteúdo da sanção imposta em seu segundo momento, na qual se exacerba o fator comando, ou mandamento". DINAMARCO, Cândido Rangel. Instituições de Direito Processual Civil: Volume III. São Paulo: Malheiros, $7^{\circ}$ ed. ver. e atual., 2017, p. 293. 
pressuposto o reconhecimento da "mora contratual" do governante e, portanto, a "declaração" do não cumprimento da proposta, bem como a "condenação", ou seja, a determinação para que a tutela seja implementada diretamente, instituindo-se um título executivo judicial, cujos efeitos ocorrerão apenas a partir da prolação da sentença (ex nunc) ou do termo indicado no título. Trata-se da criação de uma nova situação jurídicoprocessual a partir do qual o estado-juiz, substituindo-se à parte autora, vale-se da execução forçada para entregar o "bem da vida" tutelado, qual seja o compromisso encapsulado em "cláusula elegível a direito" nos "contratos políticos".

Se o recurso que desafiar referida sentença possuir, como regra, efeito suspensivo, estará esvaziado o objetivo da tutela específica. Sugere-se que seja seguido o procedimento das sentenças condenatórias mandamentais, em que a interposição do recurso não dispõe de efeito suspensivo, sem embargo da concessão em sede monocrática pelo relator ${ }^{464}$.

Essa breve incursão procedimental na tutela jurídica das proposições eleitorais evidencia que, por se tratar de terreno ainda não explorado, muitas são as dificuldades que se apresentam, sendo necessário dissercar de forma mais profunda, essencialmente, as hipóteses de cabimento e o alcance dos provimentos jurisdicionais.

${ }^{464}$ Artigo 14, $\S 3^{\circ}$, da Lei Federal $n^{\circ} 12.016 / 2009$. 


\section{CONCLUSÃO}

O objetivo do presente trabalho consistiu em analisar as propostas eleitorais formuladas em campanha eleitoral, mais especialmente se elas ostentam algum grau de eficácia e quais seriam seus instrumentos de controle. A atualidade do tema guarda relação com o contemporânea estágio das democracias e as vicissitudes da representação política. Foi com esse escopo que buscamos dissecar o instituto das propostas eleitorais, identificando hipóteses de aprimoramento para que as propostas atuem como possível agente catalisador de incremento democrático, e não como mero instrumento de demagogia eleitoral.

A primeira conclusão que atingimos é no sentido de que a democracia sofre contemporaneamente uma grave crise gerando, não mais um flerte, mas até mesmo admiração de regimes autoritários passados por parte de parcela da cidadania, fortalecendo a ameça de uma terceira onda antidemocrática, de acordo com a classificação realizada por Przeworski. Embora as democracias mais maduras também sejam atingidas, as democracias mais jovens são as que mais sofrem os efeitos da crise de confiança. A insatisfação da cidadania com a democracia começa com a perda de confiança nas pessoas e nas estruturas que conformam o poder político. A defesa instransigente do regime democrático impõe a efetiva compreensão das razões pelas quais a cidadania tem apresentado menor apreço pela democracia. Dentre as várias causas que contribuem para a erosão democrática destacamos a crença de que a democracia está vinculada à crise de representatividade e às deficiências no desenvolvimento econômico.

A segunda conclusão refere-se à análise do vínculo político-eleitoral da representação política, em que detectamos a necessidade de uma maior aproximação da figura do exercício do mandato eletivo para cargos executivos com a vontade da população. A representação política necessita, portanto, de mecanismos de reinforcement democrático, instrumentos que confiram maior eficiência ao elemento dinâmico da representação. Esse caráter responsivo da democracia, já observado por meio dos instrumentos de democracia direta, ainda não encontra espaço estrutural naquela que é a ferramenta primordial dos regimes democráticos, a eleição. Afinal, é no escrutínio popular que o governante recebe a legitimidade para assumir a liderança executiva. 
Passamos, em seguida, à apreciação das propostas eleitorais de forma analítica, estabelecendo parâmetros teóricos e classificação das propostas. Chegamos, então, ao terceiro arremate, que se refere à constatação de que as propostas eleitorais formuladas durante o período de campanha eleitoral, na maior parte dos países democráticos, exceção feita parcialmente aos sistemas que adotam o voto programático, corresponde a um conjuto de proposições absolutamente inútil do ponto de vista jurídico, já que o cumprimento ou descumprimento não gera qualquer efeito, seja positivo ou negativo. As propostas são aceitas, portanto, como mero instrumento de bravata e demagogia eleitoral à disposição dos candidatos, que no máximo estão sujeitos à accountability vertical. E diante desta conclusão, que reputamos estar vinculada a um dos elementos de descrédito do regime democrático junto à cidadania, buscamos identificar instrumentos que pudessem oferecer algum controle das propostas pelo direito, bem como maior efetividade à sua implementação. As propostas eleitorais, até então praticamente ignoradas pelo direito, exceção feita à "forma", no que se refere a seu conteúdo poderiam se tornar mecanismos de maior valoração e de imposição cogente.

A quarta conclusão decorre da necessidade de avaliação quantitativa e qualitativa do cumprimento das propostas, representada pela sugestão de criação de ente de natureza pública que tenha por função exclusiva analisar, por meio de instrumentos técnicos, o efetivo cumprimento das proposições, gerando maior transparência e fornecendo melhores elementos para a cidadania para a escolha de representantes futuros. O órgão teria estrutura voltada à independência funcional e o produto do trabalho teria caráter informativo à cidadania para que se tenha um retrato bem acabado da confrontação entre as propostas eleitorais realizadas por um candidato e o que efetivamente foi realizado pelo representante quando eleito. No Capítulo 4 tratamos de sugerir a criação de uma autarquia de regime especial com essas características, que denominamos Agência de Verificação de Propostas Eleitorais, e que funcionaria tanto em âmbito federal como estadual. Além disso, diante de determinado grau de descumprimento das propostas, penalidades poderiam ser previstas em lei como, por exemplo, a vedação à reeleição.

A quinta conclusão compreende sugestão que se refere a viabilizar uma maior coercibilidade dos compromissos realizados em campanha, aumentando o rol de inelegibilidades, incluindo-se como hipótese, o descumprimento de compromissos específicos, como a promessa de cumprimento integral do cargo originário para o qual foi eleito. 
Em seguida, trazemos a possibilidade de criação de "contratos políticos", desenvolvidos originalmente por Hans Gersbach, em que se autorizaria que o candidatoproponente apresentasse determinados compromissos e consequências, positivas e negativas, para o caso de cumprimento e descumprimento. Ao eleger o candidato, a cidadania-aceitante, que estaria no outro polo desta figura assemelhada ao "contrato", aderiria à avença diante das proposições do candidato-proponente. Estes "contratos" passariam pela análise prévia de uma autoridade certificadora que cotejaria os compromissos com a constitucionalidade e legalidade das propostas, bem como com a possibilidade de aferição do cumprimento.

O quinto capítulo apresenta a derradeira conclusão, no sentido de que, em limitadas situações, o Poder Judiciário, por meio de tutela coletiva, poderia substituir a omissão da autoridade executiva, e prover diretamente o cumprimento das propostas, desde que o candidato voluntariamente submetesse tais propostas, no bojo de um contrato político, à referida situação de exigência judicial do conteúdo da proposta. Denominamos estes ajustes como "cláusulas elegíveis a direito" em que o próprio candidato voluntariamente afirma que o descumprimento de determinada proposta poderia dar ensejo à tutela judicial específica.

Tanto em sede de controle administrativo com em sede de controle de tutela judicial apresentamos algumas ideias relacionadas ao procedimento, com o intuito de avançar do campo das ideias para a efetiva materialização da teoria apresentada.

O fio condutor de todas as medidas sugeridas consiste em fomentar, de um lado a transparência, e de outro a vinculação contratual entre as propostas eleitorais, gerando maior accountability à cidadania, eficácia e reforço democrático ao sistema como um todo. Ao trilhar esse caminho, em várias oportunidades nos deparamos com todas as dificuldades inerentes à confluência entre as esferas da política e do direito.

Durante a pesquisa identificamos a complexidade inerente à análise das hipóteses de escusas de descumprimento e revisão dos compromissos, tanto para o controle administrativo como para o controle de tutela judicial.

A pesquisa que realizamos certamente traz muito mais perguntas do que respostas, sobretudo porque em alguns momentos, trilhamos caminhos que não foram ainda percorridos na interface entre a política e o direito.

Certamente, muitas são as vicissitudes que envolvem os incrementos democráticos, mas acreditamos ser indispensável lançar luzes sobre as propostas eleitorais, que possuem 
baixa densidade jurídica. Necessário, pois, que sejam criados instrumentos que valorizem efetiva e juridicamente as propostas eleitorais. 


\section{REFERÊNCIAS}

\section{Geral}

AARTS, Kees, THOMASSEN, Jacques e VAN HAM, Carolien. "Globalization, Representation, and Attitudes towards Democracy”. In: THOMASSEN, Jacques (editor) Elections and Democracy. Michigan: Oxford University Press, 2014.

ACHEN, Christopher. H. e BARTELS, Larry M. Democracy for realists Why Elections Do not Produce Responsive Government. Princeton: Princeton University Press, 2016, 390 p.

ANDRADE, Adriano; MASSON, Cleber; ANDRADE, Landolfo. Interesses Difusos e Coletivos. São Paulo: Método, $7^{\circ}$ ed. rev. atual. e ampl., 2017. 893 p.

ANDUIZA, Eva e BOSCH, Agustí. Comportamiento político y electoral. Barcelona: Ariel, 2000. 282 p.

AGESTA, Luis Sanchez. Princípios de Teoría Política. Madrid: Editora Nacional, 3. E.d., 1970. 540 p.

AGOSTINHO, Santo. A Cidade de Deus (contra os pagãos) (Trad. Oscar Paes Leme). Parte I, $2^{\text {a }}$ ed., Petrópolis: Editora Vozes, 2014. 535 p.

ARISTÓTELES. A Política (Trad. Roberto Leal Pereira). São Paulo: Martins Fontes, 1991.

BAUMAN, Zygmunt. Modernidade Líquida (Trad. Plínio Dentzien). Rio de Janeiro: Jorge Zahar Ed., 2001. 258 p.

BAUMGARTNER, J.; KADA, N. CHECKING EXECUTIVE POWER Presidential Impeachment in Comparative Perspective. Westport, CT: Praeger Publishers, 2003, Kindle Edition.

BERCOVICI, Gilberto. "Constituição e Política: uma relação difícil”. Lua Nova, São Paulo, $\mathrm{n}^{\circ}$ 61, 2004. Disponível em <http://www.scielo.br/pdf/ln/n61/a02n61.pdf>. Acesso em 31/01/2019.

BERLIN, Isaiah. Dos Conceptos de Libertad. El fin justifica los medios. Mi trayectoria intelectual (Traducción de Ángel Rivero). Madrid: Alianza Editorial, $2^{\circ}$ ed, 2014. 199 p. 
BERRINGTON, Hugh. "Dialogue of the deaf? The Élite and the Electorate in MidCentury Britain”. In: KAVANAGH, Dennis (org). Electoral Politics. Oxford: Clarendon Press, 1992. 71-96 pp.

BOBBIO, Norberto. Democracia e Segredo (Trad. Marco Aurélio Nogueira). São Paulo: Editora Unesp, 2015. 83 p.

O Futuro da Democracia (Trad. Marco Aurélio Nogueira). São

Paulo: Paz e Terra, 2000. 207 p.

BOWLER, Shaun e FARRELL, David M. "The Study of Election Campaigning". In: Electoral Strategies and Political Marketing (Orgs.). NY: The Macmillan Press Ltd, 1992. $245 \mathrm{p}$.

BUCCI, Maria Paula Dallari. Fundamentos para uma Teoria Jurídica das Políticas Públicas. São Paulo: Saraiva, 2013. 319 p.

BRANCO, Rilke Rithcliff Pierre. "Responsabilidades Político-Eleitorais, o Impeachment, a Improbidade e a Demagogia". Revista Temas Socio-Jurídicos. Bucamaranga, Colombia, v. 36, ed. 73, p. 141-152, julho-dezembro, 2017. Disponível em: <https://revistas.unab.edu.co/index.php/sociojuridico/article/view/2858/2376>.

BRENNAN, Jason. Against Democracy. Princeton: Princeton University Press, 2016. $288 \mathrm{p}$.

CAGGIANO, Monica Herman S. “A reeleição: tratamento constitucional (breves considerações)". Preleções Acadêmicas, CEPS - Centro de Estudos Políticos e Sociais de São Paulo, Caderno 1, 1997.

. "Democracia x constitucionalismo: um navio à deriva?" Cadernos de Pós-Graduação em Direito: estudos e documentos de trabalho / Comissão de PósGraduação da Faculdade de Direito da USP, São Paulo, n. 1, 2011. . Sistemas Eleitorais x Representação Política. São Paulo: Centro Gráfico do Senado Federal, 1987. . Oposição na Política. São Paulo: Angelotti, 1995.

CAPANO, Fernando Fabiani. "O Poder Judiciário e o movimento do constitucionalismo. Reflexões sobre o ativismo judicial no contexto da doutrina da separação dos poderes". 180 f. Dissertação (Mestrado) - Faculdade de Direito. Universidade Presbiteriana Mackenzie. São Paulo, 2011.

CARVALHO, Volgane Oliveira. Direitos Políticos no Brasil. O Eleitor no Século XXI. Curitiba: Juruá Editora, 2016. 150 p. 
CASTELLS, Manuel. Ruptura: a crise da democracia liberal. Trad. Joana Angélica d'Ávila Melo. Rio de Janeiro: Zahar, 2018. 150 p.

COMPARATO, Fabio Konder. A Afirmação Histórica dos Direitos Humanos. São Paulo: Saraiva, $6^{\circ}$ ed. rev. atual., 2008. 577 p.

Rumo à Justiça. São Paulo: Saraiva, 2. Ed., 2013.

CAMPILONGO, Celso Fernandes. Política, sistema jurídico e decisão judicial. São Paulo: Saraiva, $2^{\circ}$ ed., 2011. 195 p.

CONTI, José Maurício. Levando o Direito Financeiro a Sério. São Paulo: Blucher, 2016. 241 p.

COSTA NETO, José Wellington Bezerra da. Protagonismo Judicial - Novo Ativismo e Teoria Geral da Função Jurisdicional. São Paulo: Leud, 2017. 504 P.

DAHL, Robert A. A Constituição Norte-Americana é Democrática? (tradução de Vera Ribeiro, revisão técnica de Mario Brockmann Machado). Rio de Janeiro: FGV Editora, 2015. 192 p.

- Sobre a democracia (Trad. Beatriz Sidou). Brasília: Editora Universidade de Brasília, 2001. 230 p.

Poliarquia. (Trad. Celso Maduro Paciornick). São Paulo: Editora da Universidade de São Paulo, 2015.

DEBORD, Guy. A sociedade do espetáculo (Trad.: Estela dos Santos Abreu). Rio de Janeiro: Contraponto, 1997.

DÍAZ, Angel Eduardo Alvarez. "Los contenidos de la propaganda electoral y la protecction de la racionalidad politica del elector". In: MAGALLANES, Manuel Vicente (coord.) Propaganda Política Partidos y Sistema Electoral. Consejo Supremo Electoral, Colección del Cincuentenario 2. Caracas: Miguel Angel García e Hijo, s.r.l.: 1987.

DIDIER Jr, Fredie, ZANETI Jr. Hermes. Curso de Direito Processual Civil: processo coletivo. Salvador: Ed. JusPodivm, $11^{\mathrm{a} e d ., ~ r e f ., ~ a m p l . ~ e ~ a t u a l ., ~ 2017 . ~} 543$ p.

DINAMARCO, Cândido Rangel. Instituições de Direito Processual Civil: Volume III. São Paulo: Malheiros, $7^{\circ}$ ed. ver. e atual., 2017. 895 p.

DINIZ, Maria Helena. Curso de Direito Civil Brasileiro. São Paulo: Saraiva, $15^{\circ}$ ed. rev. v.7., 2001.562 p.

DI PIETRO, Maria Sylvia Zanella. Direito Administrativo. Rio de Janeiro: Forense, 31 e.d rev. atual e ampl., 2018. 1.109 p.

DUVERGER, Maurice. Institutions Politiques et Droit Constitutionnel - Les grands système politiques. Tomo I. Paris: Presses Universitaires de France, $12^{\circ}$ Ed., 1971. 
EGEA, Antonio Robles. "Líderes para uma Democracia de Calidad". In: EGEA, Antonio Robles; ORTEGA, Ramón Vargas-Machuca (eds). La Buena Democracia Chaves de su calidad. Granada: Editorial Universidad de Granada, 1997. 155-173 p.

ESPINOSA, Baruch de. Tratado Político (Trad. Intr. e notas Diogo Pires Aurélio). São Paulo: WMF Martins Fontes, 2009.

FERNANDÉZ, Andrés Rodríguez. "La Calidad En La Admnistración Pública". In: Evaluación y Calidad en las Organizaciones Públicas. Colección: Informes y Documentos. Madrid: Instituto Nacional de Administración Pública, 2000. 99-111 p.

FERNÁNDEZ, Santiago Delgado. "Ladrándole a la Luna" Validez del Proyecto Cosmopolita a la luz de la calidad democrática. In: EGEA, Antonio Robles; ORTEGA, Ramón Vargas-Machuca (eds). La Buena Democracia Chaves de su calidad. Granada: Editorial Universidad de Granada, 1997. 155-173 p.

FERREIRA FILHO, Manuel Gonçalves. A democracia no Limiar do Século XXI. São Paulo: Saraiva, 2001.

. Curso de direito constitucional. São Paulo: Saraiva, 35 ed., 2009. $398 \mathrm{p}$. . Sete Vezes Democracia. São Paulo: Convívio, 1977.

FILGUEIRAS, Fernando. Corrupção, Democracia e Legitimidade. Belo Horizonte: Editora UFMG, 2008.

FUKUYAMA, Francis. "Why is Democracy Performing So Poorly?" In: DIAMOND, L. e PLATTNER, M. F. (eds.) Democracy in Decline? Baltimore: Johns Hopkins University Press, 2016. 127 p.

GARCÍA-PELAYO, Manuel. Las Transformaciones del Estado Contemporáneo. Caracas: Fundación Manuel García-Pelayo, 2009.

GARGARELLA, Roberto. El derecho a la protesta: El primer derecho. Buenos Aires: Ad-Hoc, 2007. 265 p.

GASPARINI, Diogenes. Direito Administrativo. São Paulo: Saraiva, $4^{\circ}$ ed - rev. e ampl., 1995. $651 \mathrm{p}$.

GERSBACH, Hans. “Contractual Democracy”. Law \& Economics, n. 823, 2012. 823-851 p. Redesigning Democracy. Zürich: Springer, 2017. 248 p.

GILBERT, Martin. Winston Churchill: uma vida: Volume II. Trad. Elisa Nogueira. São Paulo: Leya Brasil, 2016, kindle edition. 
GISBERT, Antonio Bustos. Curso Básico de Hacienda Pública. Pamplona: Editorial Aranzadi, 4. E.d., 2017. 365 p.

GONZÁlEZ, María Holgado. El Programa de Gobierno y sus Sistemas de Control. Valencia: Tirant Lo Blanch, 2008. 454 p.

GROSS, Clarissa Piterman. "Fake News e Democracia: discutindo o status normativo do falso e a liberdade de expressão". In: RAIZ, Diogo (coord.) FAKE NEWS: a conexão entre a desinformação e o direito. São Paulo: Thomson Reuters Brasil, 2018. 154$174 \mathrm{p}$.

GUTMANN, Amy e THOMPSON, Dennis. Why Deliberative Democracy? United Kingdom: Princeton Univesity Press, 2004. 232 p.

HELD, David. Models of Democracy. Cambridge: Polity Press, $3^{\circ}$ Ed., 2017. 338 p.

HERNÁNDEZ, Juan Carlos González. Derecho Electoral Español. Normas y Procedimiento. Madrid: Editorial Tecnos S/A, 141 p.

HOLBROOK, Thomas M. Do Campaigns Matter? Contemporary American Politics. Thousand Oaks, California: Sage Publications, 1999. 178 p.

KANT, Immanuel. A Paz Perpétua. Trad. Marco Zingano. Porto Alegre: L\&PM Editores, 2011, versão kindle.

KAKUTANI, Michiko. A Morte da Verdade. Trad. André Czarnobai, Marcela Duarte. 1. Ed. Rio de Janeiro: Intrínseca, 2018. 270 p.

HUNTINGTON, Samuel. P. A Terceira Onda. São Paulo: Editora Ática, 1994. $335 \mathrm{p}$.

KELSEN, Hans. A Democracia.. São Paulo: Martins Fontes, $1^{\circ}$ ed, 1993, 392 p. Teoria Geral do Direito e do Estado. Tradução de Luís Carlos Borges. $3^{\circ}$ ed. São Paulo: Martins Fontes, 1998. 637 p.

LEITE, Glauco Costa. Corrupção Política: Mecanismos de Combate e Fatores Estruturantes no Sistema Jurídico Brasileiro. Belo Horizonte: Del Rey, 2016. 202 p. "O Processo de Impeachment como Instrumento de Combate à Corrupção". In: Alexandre Jorge Carneiro da Cunha Filho; Glaucio Roberto Brites de Araujo; Roberto Livianu; Ulisses Augusto Pascolati Junior. (Org.). 48 Visões sobre a corrupção. São Paulo: Quartier Latin, 1ed., 2016, p. 447-461.

. "Reeleição Presidencial no Brasil e seus Reflexos na Qualidade Democrática e no Combate à Corrupção”. In: Regina Tamami Hirose (org.) Carreiras 
Típicas de Estado: desafios e avanços na prevenção e no combate à corrupção. Belo Horizonte: Fórum: 2019. p. 135-145.

LEMBO, Cláudio. A pessoa: seus direitos. Barueri: Manole, 2007. p. 280. . "Faltou Algo Na Lei da Ficha Limpa". In: Monica Herman Caggiano. (org.). Ficha Limpa - Impacto nos tribunais: tensões e confrontos. São Paulo: Revista dos Tribunais, 2014. 117-120 p.

LEVITSKY, Steven e ZIBLATT, Daniel. Como as democracias morrem. Tradução Renato Aguiar. Rio de Janeiro: Zahar, 2018. 270 p.

LORENCINI, Bruno. Democracia Qualificada e Responsabilidade Política. São Paulo: LiberArs, 2018, p.81

LIJPHART, Arend. Patterns of Democracy: government forms and performance in thirty-six countries. $2^{\text {nd }}$ ed. New Heaven/London: Yale University Press, 2012. 348 p.

LINCOLN, Abraham. Lincoln's Gettysburg address at the National Cemetery at Gettysburg, Pennsylvania. Disponível em Library of Congress: $<$ https://cdn.loc.gov/service/rbc/lprbscsm/scsm0365/scsm0365.pdf. Acesso em 06/09/2017>.

LISOWSKI, Telma Rocha. Mandato Parlamentar \& Crise de Representatividade: instrumentos de perda e reforma do sistema. Curitiba: Juruá, 2018. 263 p.

LORENCINI, Bruno. Democracia qualificada e responsabilidade política. São Paulo: Liberars, 2018. 311p.

LUQUE, Teodoro. Márketing Político. Un análisis del intercambio político. Barcelona: Editorial Ariel, 1996. 227 p.

MARAVALL, José María. Las promesas políticas. Barcelona: Galaxia Gutemberg, 2013. 220 p.

MARQUES NETO, Floriano de Azevedo. "A Bipolaridade do Direito Administrativo e sua Superação”. In: ARAGÃO, Alexandre Santos de; MARQUES NETO, Floriano de Azevedo (Coord.) Direito Administrativo e seus novos paradigmas. Belo Horizonte: Fórum, 2018. 615 P.

MARSHALL, T. H. "Cidadania e Classe Social" In. Cidadania, classe social e status. Rio de Janeiro: Jorge Zahar Editores, 1967.

MARTÍNEZ I COMA, Ferran. ¿Por qué importan las campañas electorales? Colección <Monofrafías>, $\mathrm{n}^{\circ}$ 260. Centro de Investigaciones Sociológicas. Madrid: EFCA S.A., 2008. 288 p. 
MAXIMILIANO, Carlos. Comentários à Constituição Brasileira. V. II. Rio de Janeiro: Freitas Barros, $5^{\circ}$ ed. (atualizada), 1954.

MAZZILLI, Hugo Nigro. A defesa dos interesses difusos em juízo: meio ambiente, consumidor, patrimônio cultural, patrimônio público e outros interesses. São Paulo: Saraiva, 25 ed. rev. ampl. e atual., 2012. 912 p.

MEIRELLES, Hely Lopes. Direito Administrativo Brasileiro. São Paulo: Malheiros, $32^{\circ}$ ed., 2006. 826 p.

MELlo, Celso Antônio Bandeira de. Curso de Direito Administrativo. São Paulo: Malheiros, $34^{\mathrm{a}}$ ed., ref., e atual., 2019. 1179 p.

MENDES, Gilmar Ferreira e BRANCO, Paulo Gustavo Gonet. Curso de Direito Constitucional. São Paulo: Saraiva, 12 ed. rev. e atual., 2017. 1576 p.

MENEZES, Fernanda Montenegro de. "Marketing Político. Eleições Municipais de 2008”. In: LEMBO, Cláudio (Coord.); CAGGIANO, Monica Herman Salem (Org.). Comportamento Eleitoral. Barueri: Manole, 2010.

MODOLO, Artur Daniel Ramos. Hipertextualidade e relações dialógicas no gênero digital microblog político dos candidatos à presidêcia do Brasil nas eleições 2010. Dissertação de Mestrado Faculdade de Filosofia, Letras e Ciências Humanas, Universidade de São Paulo, 2011. 156p.

MOISÉS, José Alvaro. “A Confiança e os seus Efeitos sobre as Instituições Democráticas". In: MOISÉS, José Alvaro. (org.) Democracia e Confiança - Por que os Cidadãos Desconfiam das Instituições Públicas? São Paulo: Editora Universidade de São Paulo, 2010. 304 p.

. "Democracia e Desconfiança das Instituições Democráticas". In: MOISÉS, José Alvaro. (org.) Democracia e Confiança - Por que os Cidadãos Desconfiam das Instituições Públicas? São Paulo: Editora Universidade de São Paulo, 2010. 304 p.

MOLES Y PLAZA, Ramon J. Derecho y calidad: El régimen jurídico de la normatización técnica. Barcelona: Ariel, 2001. 322 p.

MORAES, Alexandre de. Direito constitucional. São Paulo: Atlas, $25^{\circ}$ ed., 2010. $922 \mathrm{p}$.

MORAES, Antonio Carlos Flores de. Legalidade, Eficiência e Controle da Administração Pública. Belo Horizonte: Fórum, 2007. 256 p.

MOREIRA NETO, Diogo de Figueiredo. Curso de Direito Administrativo: parte introdutória, parte geral e parte especial. Rio de Janeiro: Forense, $15^{\circ}$ ed. rev. ref. e atual., 2009. $759 \mathrm{p}$. 
MORLINO, Leonardo. "Teoria da Democratização, Qualidade da Democracia e Pesquisa de Opinião: Ainda em 'Mesas Separadas'”. In: MOISÉS, José Alvaro. (org.) Democracia e Confiança - Por que os Cidadãos Desconfiam das Instituições Públicas? São Paulo: Editora Universidade de São Paulo, 2010. 304 p.

MONTESQUIEU, Charles-Louis de Secondat. De l'esprit des loi. Paris: Vve Dabo, 1824.

MUNIZ, Carlos et al. “¿Están los políticos políticamente comprometidos?: Análisis del compromiso político 2.0 desarrollado por los candidatos a través de Facebook" .Cuadernos.info, Santiago, n. 39, p. 135-150, dic. 2016. Disponível em $<$ https://scielo.conicyt.cl/scielo.php?script=sci_arttext\&pid=S0719367X2016000200009\&lng=es\&nrm=iso>. Acesso em 21 de maio 2019. http://dx.doi.org/10.7764/cdi.39.970.

NEISSER, Fernando Gaspar. Crime e Mentira na Política. Belo Horizonte: Editora Forum, 2016. 295 p.

NICHOLS, Tom. The Death of Expertise. New York: Oxford University Press, 2017. $252 \mathrm{p}$.

NINO, Carlos Santiago. La constitución de la democracia deliberativa. Barcelona: Gedisa Editorial, 1997. 302 p.

NOHARA, Irene Patrícia. "Desafios da ciberdemocracia diante do fenômeno das fake news: regulação estatal em face dos perigos da desinformação". In: RAIZ, Diogo (coord.) FAKE NEWS: a conexão entre a desinformação e o direito. São Paulo: Thomson Reuters Brasil, 2018. 75-88 p.

O'DONNELL, Guillermo. "Nuevas Reflexiones acerca de la democracia delegativa (DD)". In: O’DONNELL, Guillermo; IAZZETTA, Osvaldo; QUIROGA, Hugo (coord.) Democracia delegativa. Buenos Aires: Prometeo Libros, 2011. 204 p.

ORTEGA, Ricardo Rivero; AGUILAR, Víctor Granda. Derecho Administrativo. Quito: Corporación Editora Nacional, 2017.252 p.

PEREZ, Marcos Augusto. "Controle da Discricionariedade Administrativa". In: PEREZ, Marcos Augusto; SOUZA, Rodrigo Pagani de (coord.) Controle da Administração Pública. Belo Horizonte: Fórum, 2017. Edição Kindle.

PÉREZ-LIÑÁN, Aníbal. Presidential Impeachment and the new political instability in Latin America. Cambridge, MA: Harvard University Press, 2007, Kindle Edition. 
PITKIN, Hanna Fenichel. El Concepto de Representacion. Madri: Imprenta Fareso, 1985. $289 \mathrm{p}$.

PLATÃO. A República. São Paulo: Edipro, 2001. 419 p.

POSNER, R. A. AN AFFAIR OF STATE - The Investigation, Impeachment and Trial of President Clinton. Cambridge, MA: Harvard University Press, 1999, Kindle Edition.

PRZEWORSKI, Adam. Democracia e mercado: reformas políticas e economicas no Leste Europeu e na America Latina. Rio de Janeiro: Relume-Dumara, 1994. 270 p.

RAIZ, Diogo. FAKE NEWS E ELEIÇÕES. In: RAIZ, Diogo (coord.) FAKE NEWS: a conexão entre a desinformação e o direito. São Paulo: Thomson Reuters Brasil, 2018. 105-129 p.

RANCIÈRE, JACQUES. O ódio à democracia. São Paulo: Boitempo, 2014, 125 p.

ROCHLIN, Nick. "Fake news: belief in post-truth", Library Hi Tech, Vol. 35 Issue: 3, pp.386-392, (2017). Disponível em: <https://doi.org/10.1108/LHT-03-2017-0062〉. Acesso em 18/05/2019.

ROUSSEAU, Jean-Jacques. Le Contrat Social. $1^{\circ}$ ed. Paris, 1851.

RUSSETT, Bruce. Controlling the Sword: The Democratic Governance of National Security, Cambridge, Harvard University Press, 1990. 201 p.

RUSSO, Alberto. Programma di Governo e Regime Parlamentar. Milão: Giuffré Editore, 1984. 223 p.

SALAMANCA, Felipe Rey. Voto Programático y Programas de Gobierno en Colombia. Bogotá: Universidad del Rosario, Facultad de Jurisprudencia, 2015. 234 p.

SARTORI, Giovanni. A Teoria da Democracia Revisitada. Vol. 2. São Paulo: Ática, 1994.

SCHUMPETER, Joseph A. Capitalismo, Socialismo e Democracia (Tradução Luiz Antônio Oliveira de Araújo). São Pulo: Editora Unesp, 2017. 582 p.

SIYÈS, Abade. Exposição Refletida dos Direitos do Homem e do Cidadão. Organização, estudo introdutório e tradução de Emerson Garcia. São Paulo: Atlas, 2015.

STEENBERGEN, Marco R. e LODGE, Milton. Process Matters: Cognitive Models of Candidate Evaluation. In: MACKUEN, B. Michael e RABINOWITZ, George (Orgs.). Electoral Democracy. Michigan: The University of Michigan Press, 2003. 336 p.

SOARES, Alessandro. A Democracia Direta no Constitucionalismo LatinoAmericano e Europeu: análise comparada de Venezuela, Equador. Brasil e Espanha. São Paulo: LiberArs, 2017. 570 p. 
SOUZA, Rodrigo Pagani de. "Em Busca de Uma Administração Pública de Resultados”. In: PEREZ, Marcos Augusto; SOUZA, Rodrigo Pagani de (coord.) Controle da Administração Pública. Belo Horizonte: Fórum, 2017. Edição Kindle.

STRECK, Lenio Luiz e MORAIS, José Luis Bolsan de. Ciência Política \& Teoria do Estado. 7. ed. Porto Alegre: Livraria do Advogado Editora, 2012, 224 p.

SUÁREZ, Francisco. De Legibus I De Natura Legis. Edición crítica bilíngue por Luciano Pereña. Corpus Hispanorum de Pace. Madrid: Consejo Superior de Investigaciones Científicas, 1971. Vol. XI, 359 p.

.. De Legibus (III 1-16) De Civili Potestate. Edición crítica bilíngue

por Luciano Pereña. Corpus Hispanorum de Pace. Madrid: Consejo Superior de Investigaciones Científicas, 1975. Vol. V, 404 p.

TELLO, Pilar Jimenez. Auditoría Universitaria y Calidad. La evaluación como conquista social ante la competencia universitaria global. Saarbrücken: VDM Verlag Dr. Müller, 2009. 469 p.

TOCQUEVILlE, Alexis. A Democracia na América: leis e costumes (Tradução de Eduardo Brandao). São Paulo: Martins Fontes, 2001.

URBINATI, Nadia. Representative Democracy. Chicago: University of Chicago Press, 2006. 328 p.

VILLEGAS, Mauricio Garcia. "Constitucionalismo Aspiracional: Derecho, Democracia y Cambio Social en América Latina”. Revista Análisis Politico. Bogota, v. 25, ed. 75, maio-agosto, 2012, pp. 89-110. Disponível em: <https://revistas.unal.edu.co/index.php/anpol/article/view/43508/44797>.

VITORIA, Francisco de. Relectio de Postestate Civili. Estudios sobre su Filosofía Política. Edición crítica por Jesús Cordero Pando. Corpus Hispanorum de Pace Segunda Serie. Madrid: Consejo Superior de Investigaciones Científicas, 2008. Vol. 15, 540 p.

\section{Sítios eletrônicos consultados}

Aplicativo Mudamos+. Disponível em: <https://www.mudamos.org/quem-somos>. Acesso em 05/04/2018.

Bancada Ativista. Disponível em: <https://bancadaativista.org/>. Acesso em $27 / 11 / 2019$. 
Canada Statistics Act 1985. Disponível em: <https://lawslois.justice.gc.ca/eng/acts/S-19/page-1.html?txthl=statistical+statistics\#s-4>. Acesso em 29/11/2019.

Congresso em foco. Disponível em: $<$ https://congressoemfoco.uol.com.br/eleicoes/maioria-dos-presidenciaveis-defendedesarmamento-veja-a-posicao-de-cada-um/>. Acesso em 13/03/219.

Consulta Polpular Anticorrupción en Colombia. Disponível em: <https://elecciones1.registraduria.gov.co/pre_cpa_20180826/consultas/html/inicio.html>. Acesso em 22/10/2018.

Eurostats. Disponível em: <https://ec.europa.eu/eurostat/statisticsexplained/index.php?title=Glossary:Eurostat $>$. Acesso em 22/11/2018.

Fórum de Segurança Pública. Disponível em: <http://www.forumseguranca.org.br/perfil/apresentacao/>. Acesso em: 19/02/2019.

Ibope Inteligência. Disponível em: <http://www.ibopeinteligencia.com/noticias-epesquisas/jair-bolsonaro-fica-numericamente-a-frente-mas-tecnicamente-empatado-commarina-silva-na-ausencia-de-lula-na-disputa-pela-presidencia-da-rep/>. Acesso em 26/10/2018.

Justiça Eleitoral. Disponível em: <http://www.justicaeleitoral.jus.br/desinformacao/>. Acesso em 09/12/2019.

"Mandata Juntas Codeputadas Estaduais". Disponível em: <https://www.juntascodeputadas.com.br>. Acesso em 16/05/2019.

Latinobarómetro. Disponível em: <http://www.latinobarometro.org/latOnline.jsp>. Acesso em 13/09/2019.

Programa do Partido Político Podemos (Espanha). Disponível em: <https://podemos.info/wp-content/uploads/2015/05/programa_marco_podemos.pdf>. Acesso em 25/09/2018.

Programa do Partido Político Vox (Espanha). Disponível em: <https://www.voxespana.es/wp-content/uploads/2015/12/Programa-electoral-VOX-26J.pdf>. Acesso em 29/10/2019.

Programa do Partido Político PSOE (Espanha). Disponível em: $<$ https://www.psoe.es/media-content/2019/04/PSOE-programa-electoral-eleccionesgenerales-28-de-abril-de-2019.pdf>. Acesso em 29/10/2019, 
Rede Nossa São Paulo. Disponível em: $\langle$ https://www.nossasaopaulo.org.br/portal/arquivos/metas-programa-doria.pdf $>$. Acesso em 25/09/2018.

Tribunal Superior Eleitoral. Disponível em: $<$ http://www.tse.jus.br/hotsites/esclarecimentos-informacoes-falsas-eleicoes-2018/>. Acesso em $09 / 12 / 2019$.

\section{Legislação e Jurisprudência}

ALEMANHA. Constituição de Weimar de 1919. Disponível em: <http://www.documentarchiv.de/wr/wrv.html\#ERSTER_ABSCHNITT>. Acesso em $06 / 02 / 2019$.

ARGENTINA. Código Electoral Nacional, Ley n ${ }^{\circ} 19.945$ de 14 de novembro de 1972. Disponível em: <https://bcn.gob.ar/uploads/Codigo-Electoral-Nacional-mayo2019.pdf>. Acesso em 28/11/2019.

BOLIVIA. Ley del Régimen Electoral, 30 de junio de 2010. Disponível em:< https://www.lexivox.org/norms/BO-L-N26.html>. Acesso em 28/11/2019.

BRASIL. Constituição Federal de 1988. Disponível em <http://www.planalto.gov.br/ccivil_03/Constituicao/Constituicao.htm>. Acesso em $27 / 11 / 2019$.

BRASIL. Constituição do Império do Brazil de 1824. Disponível em <http://www.planalto.gov.br/ccivil_03/Constituicao/Constituicao.htm>. Acesso em $27 / 11 / 2019$.

BRASIL. Congresso Nacional. Lei Complementar $n^{\circ}$ 135, de 4 de junho de 2010. Disponível em <http://www.planalto.gov.br/ccivil_03/leis/lcp/lcp135.htm>. Acesso em $27 / 11 / 2019$.

BRASIL. Congresso Nacional. Lei Federal n 9.096/95, de 19 de setembro de 1995 $\begin{array}{lllll}\text { (Lei } & \text { dos } & \text { Partidos } & \text { Políticos). } & \text { Disponível }\end{array}$ <http://www.planalto.gov.br/ccivil_03/leis/19096.htm>. Acesso em 27/11/2019.

BRASIL. Congresso Nacional. Lei Federal n 9.504/97, de 30 de setembro de 1997 (Lei das Eleições). Disponível em http://www.planalto.gov.br/ccivil_03/LEIS/L9504.htm. Acesso em 27/11/2019. 
BRASIL. Congresso Nacional. Lei Federal n 4.737/1965, de 15 de julho de 1965 (Código Eleitoral). $\quad$ Disponível em: http://www.planalto.gov.br/ccivil_03/leis/14737.htm>. Acesso em 28/11/219.

BRASIL. Congresso Nacional. Lei Complementar $n^{\circ}$ 64/1990, de 18 de maio de 1990. Disponível em: <http://www.planalto.gov.br/ccivil_03/leis/lcp/lcp64.htm>. Acesso em 28/11/219.

BRASIL. Congresso Nacional. Lei Federal n 13.165/2015, de 29 de setembro de 2015. Disponível em: <http://www.planalto.gov.br/ccivil_03/_ato20152018/2015/lei/113165.htm>. Acesso em 28/11/219.

BRASIL. Congresso Nacional. Lei Federal $n^{\circ}$ 12.527, de 18/11/2011 (Lei de Acesso à Informação. Disponível em: <http://www.planalto.gov.br/ccivil_03/_ato20112014/2011/lei/112527.htm>. Acesso em 28/11/2019.

BRASIL. Presidência da República. Decreto $n^{\circ} 76.664$, de 24 de novembro de 1975. Disponível em: <http://legis.senado.leg.br/norma/499304/publicacao/15644421>. Acesso em 29/11/2019.

BRASIL. Senado Federal. Projeto de Lei $n^{\circ}$ 229/2009. Disponível em: < https://www25.senado.leg.br/web/atividade/materias/-/materia/91341>. Acesso em 28/11/2019.

BRASIL. Supremo Tribunal Federal. ARE 639.337/SP, Rel. Min. Celso de Mello, DJ. 23.8.2011. Disponível em <www.stf.jus.br>. Acesso em 27/11/2019.

BRASIL. Supremo Tribunal Federal. RE 848826, Rel. Min. Roberto Barroso, julgado em 10/08/2016. Disponível em <www.stf.jus.br>. Acesso em 27/11/2019.

BRASIL. Supremo Tribunal Federal. ADI 5081, Rel. Min. Luís Roberto Barroso, julgada em 27/05/2015. Disponível em <www.stf.jus.br>. Acesso em 27/11/2019.

BRASIL. Supremo Tribunal Federal. RE 598099/MS, Rel. Min. Gilmar Mendes, julgada em 10/08/2011. Disponível em <www.stf.jus.br>. Acesso em 27/11/2019.

BRASIL. Tribunal de Justiça do Estado de São Paulo. Recurso Inominado 1015799-63.2017.8.26.0554, Rel. Glauco Costa Leite, julgado em 06/02/2018.

BRASIL. São Paulo. Lei Orgânica do Município de São Paulo. Disponível em: <https://www.prefeitura.sp.gov.br/cidade/secretarias/upload/educacao/cme/LOM.pdf>. Acesso em 28/11/2019.

BRASIL. São Paulo. Lei Estadual n 1.866, de 4 de dezembro de 1978. Disponível em:<https://www.al.sp.gov.br/repositorio/legislacao/lei/1978/lei-186604.12.1978.html>.Acesso em 29/11/2019. 
CHILE. Ley Organica Constitucional sobre Votaciones Populares y Escrutinios (Ley $\mathrm{n}^{\circ} 18.700 / 2016$ de 18 de outubro de 2016). Disponível em: $<$ https://www.leychile.cl/Navegar?idNorma=30082\&idVersion=2016-10-18>. Acesso em 28/11/2019.

COLOMBIA. Constitución Politica de Colombia. Disponível em: $<$ http://www.corteconstitucional.gov.co/inicio/Constitucion\%20politica\%20de\%20Colomb ia.pdf >. Acesso em 28/11/2019.

ESPANHA. Constitución Española de 1978. Disponível em: http://www.congreso.es/docu/constituciones/1978/1978_cd.pdf. Acesso em 05/02/2019.

ESPANHA. Constitución Española de 1812. Disponível em: < http://www.congreso.es/constitucion/ficheros/historicas/cons_1812.pdf >. Acesso em 06/02/2019.

ESPANHA. Ley $\mathrm{n}^{\circ}$ 12, de 9 de maio de 1989 (Ley de la Función Estadística Pública). Disponível em: <https://www.boe.es/eli/es/1/1989/05/09/12>. Acesso em $29 / 11 / 2019$

ESPANHA. Ley de Ordenación del Regimen Electoral General $n^{\circ}$ 5/1985. Disponível em: <http://www.juntaelectoralcentral.es/cs/jec/loreg>. Acesso em 25/01/2018.

EQUADOR. Ley Orgánica Electoral, Código de la Democracia, de 27 de abril de 2009. Disponível em: <http://aceproject.org/ero-en/regions/americas/EC/ecuador-leyorganica-electoral-codigo-de-la/>. Acesso em 28/11/2019.

ESTADOS UNIDOS. Title 18 US Code §599. Disponível em: <https://www.govinfo.gov/app/details/USCODE-2011-title18/USCODE-2011-title18partI-chap29-sec599>. Acesso em 28/11/2019.

MEXICO. Constitución de los Estados Unidos Mexicanos de 1917. Disponível em: $\langle$ https://archivos.juridicas.unam.mx/www/bjv/libros/6/2802/8.pdf $>$ Acesso em $06 / 02 / 2019$

MEXICO. da Ley General de Instituciones y Procedimientos Electorales. Disponível em: <https://www.te.gob.mx/consultareforma2014/node/5165>. Acesso em 28/11/2019.

PARAGUAI. Codigo Electoral Paraguayo (Lei n 834/96, de 17 de abril de 1996). Disponível em: < http://tsje.gov.py/static/ups/legislaciones/1996-ley-834.pdf>. Acesso em 28/11/2019. 
PERU. Ley de Oganizaciones Políticas (Lei n 28094 de 31 de outubro de 2003). Disponível em: <https://portal.jne.gob.pe/portal_documentos/files/fd6aadd2-0361-433b8cab-aef2a0c568b7.pdf>. Acesso em 28/11/2019.

PERU. Proyecto de Ley $n^{\circ}$ 1.313/2016 (Anteprojeto de Código Eleitoral Peruano) Disponível em: <http://portal.jne.gob.pe/portal_documentos/files/d408f47a-9367-460aa0e5-f0d84d7f524d.pdf>. Acesso em 28/11/2019.

VENEZUELA. Ley Orgánica de Procesos Electorales. Disponível em: < http://www4.cne.gob.ve/onpc/web/documentos/Leyes/Ley_Organica_de_los_Procesos_Ele ctorales.pdf>. Acesso em 28/11/2019.

\section{Notícias de periódicos}

“44\% dos eleitores se dizem pessimistas com eleição de 2018, diz Ibope". Portal G1. Disponível em: <https://g1.globo.com/politica/eleicoes/2018/noticia/44-dos-eleitoresse-dizem-pessimistas-com-eleicao-de-2018-diz-ibope.ghtml>. Acesso em 13/03/2018.

BOGHOSSIAN, Bruno. 'Não fui ao cartório', diz Serra sobre promessa de campanha em 2004. Estadão, 20/03/2012. Disponível em: $<$ http://politica.estadao.com.br/noticias/geral,nao-fui-ao-cartorio-diz-serra-sobre-promessade-campanha-em-2004,851093>. Acesso em 22/03/2018.

"Bolsonaro confirma que solicitou exoneração de diretor do Inpe". Disponível em: $<$ https://exame.abril.com.br/brasil/bolsonaro-confirma-que-solicitou-exoneracao-dediretor-do-inpe/>. Acesso em 21/10/2019.

"Comunidad de San Buenaventura pone al cepo a su alcalde Javier Delgado". El Deber. Santa Cruz de la Sierra, Bolívia. Disponível em: $<$ http://www.eldeber.com.bo/santacruz/Comunidad-de-San-Buenaventura-pone-al-cepo-asu-alcalde-Javier-Delgado-20180227-0001.html> . Acesso em 01/03/2018.

“Contrariando promessa, João Doria se lança ao governo de SP” Disponível em: $<$ https://catracalivre.com.br/geral/cidadania/indicacao/contrariando-promessa-joao-doriase-lanca-ao-governo-de-sp/>. Acesso em 22/03/2018.

"Negar Holocausto não é liberdade de expressão, decide corte europeia". Disponível em: <https://www.dw.com/pt-br/negar-holocausto-n\%C3\%A3o-\%C3\%A9liberdade-de-express\%C3\%A3o-decide-corte-europeia/a-50697201>. Acesso em: 07/10/2019. 
"No Twitter, Bolsonaro rebate críticas de vice Mourão ao $13^{\circ}$ salário". Disponível em: $\quad<$ https://exame.abril.com.br/brasil/no-twitter-bolsonaro-rebate-criticas-de-vicemourao-ao-13o-salario/>. Acesso em 28/02/2019.

"Negar Holocausto não é liberdade de expressão, decide corte europeia". Disponível em: <https://www.dw.com/pt-br/negar-holocausto-n\%C3\%A3o-\%C3\%A9liberdade-de-express\%C3\%A3o-decide-corte-europeia/a-50697201>. Acesso em: 07/10/2019.

“No Twitter, Bolsonaro rebate críticas de vice Mourão ao $13^{\circ}$ salário". Disponível em: $\quad$ <https://exame.abril.com.br/brasil/no-twitter-bolsonaro-rebate-criticas-de-vicemourao-ao-13o-salario/> . Acesso em 28/02/2019.

"Para 61\% dos brasileiros, posse de armas de fogo deve ser proibida, diz Datafolha". Disponível em: <https://g1.globo.com/politica/noticia/2018/12/31/para-61-dosbrasileiros-posse-de-armas-de-fogo-deve-ser-proibida-diz-datafolha.ghtml> . Acesso em 07/06/2019.

"Raggi: nel contratto multa da 150 mila euro e clausola dimissioni". Disponível em Corriere Della Sera: <https://www.corriere.it/politica/16_settembre_11/raggi-contrattomulta-150-mila-euro-clausola-dimissioni-209277f4-779a-11e6-a5b1-4fe0f4d. Acesso em $05 / 04 / 2018$.

"Trump says he 'never meant Mexico would write a check' for the wall". Disponível em: <https://www.cnbc.com/2019/01/10/trump-says-mexico-is-not-going-towrite-a-check-for-the-wall-contradicting-campaign-pledge.html>. Acesso em 14/02/2019.

“Zema diz que errou ao prometer que não pagaria salário a secretários estaduais" Disponível em: <https://politica.estadao.com.br/noticias/geral,zema-diz-que-errou-aoprometer-que-nao-pagaria-salario-a-secretarios-estaduais,70002871197>. Acesso em $13 / 09 / 2019$. 